UNIVERSIDADE DE BRASÍLIA

INSTITUTO DE ARTES

PROGRAMA DE PÓS-GRADUAÇÃO EM ARTES

INGRID KALINE DE SOUZA LIMA

\title{
ARTE, TEATRO PÓS-TRAUMÁTICO E LOUCURA \\ O PROCESSO CRIATIVO DO \\ CHICQUEIRO E A LÓGICA DO PATO
}


INGRID KALINE DE SOUZA LIMA

\section{ARTE, TEATRO PÓS-TRAUMÁTICO E LOUCURA \\ O PROCESSO CRIATIVO DO \\ CHICQUEIRO E A LÓGICA DO PATO}

Dissertação apresentada como requisito parcial pelo Programa de Pós-Graduação em Artes, do Instituto de Artes da Universidade de Brasília, realizada para a obtenção do título de Mestra em Artes, sob (des)orientação da professora doutora Maria Beatriz de Medeiros 
Ficha catalográfica elaborada automaticamente, com os dados fornecidos pelo(a) autor(a)

de Souza Lima, Ingrid Kaline

Arte, Teatro Pós-Traumático e Loucura: Processo Criativo do ChicQueiro e a Lógica do Pato / Ingrid Kaline de Souza Lima; orientador Maria Beatriz de Medeiros. -- Brasília, 2016. $150 \mathrm{p}$.

Dissertação (Mestrado - Mestrado em Artes) -Universidade de Brasília, 2016.

1. Arte. 2. Teatro Pós-Traumático. 3. ChicQueiro. 4. Loucura. 5. Lógica do Pato. I. de Medeiros, Maria Beatriz, orient. II. Título. 
Aos que deliram. 


\section{AGRADECIMENTO}

Quero mandar um beijo para a minha mãe, para o meu pai e agradecer tudo o que vocês não fizeram por mim. Acreditem, isso é importante.

Quero mandar um beijo para o tempo e sua sabedoria;

Para a minha querida orientadora musa do verão Maria Beatriz de Medeiros pelo apoio e acolhimento e pela banca de defesa prof. ${ }^{a}$ Alice Stefânia e prof. Hilan Bensusan;

Para a CAPES pelo pão nosso de cada dia;

Para a Universidade de Brasília pelo espaço de pesquisa;

Para a linda equipe do Doida de Pedra (Rafaella Cavalcante, Anne Vasconcelos, Amanda Spacca, Antônio de Hollanda, Cristiane Valentin, Juliana Melo, Mariana Medeiros e Maria Eugênia Matricardi) pela força e carinho e para os colaboradores do projeto (Elisabeth Rocha, Carol Palmeira, Gina Ferreira, Laura Cardins, Maiara Ioris, Natasha Padilha, Ricardo Albuquerque e Ricardo Gauthama e Valesca);

Para os artistas generososos que compartilharam um pouco da sua prática nos eventos produzidos pelo Doida de Pedra;

Para o Hospital Ulysses Pernambucano (PE) e ao Hospital São Vicente de Paulo (HSVP), agradeço não por vocês existirem, mas por permitirem que eu entrasse com este projeto;

Para o Centro de Atenção Psicossocial (CAPS) da Região Administrativa de Taguatinga pelo bailado cigano;

Para a força e coragem dos pacientes e trabalhadores que lutam por uma reforma psiquiátrica; Para os meus/minhas amigos/amigas pela caminhada;

Para a Casa Retirante (Seu Valdir, Kika, Brenndoca, e Diogo) pela irmandade, La Conga Rosa por jogar glitter comigo e ao coletivo Corpos Informáticos, por serem maravilhosos;

Para os meus queridos ciganos do acampamento Calon e ao grupo Ciganos de Luz-PE/DF, pelo bailado junto às estrelas;

Para o terreiro, meus irmãos de corrente e pais de santo pelo acolhimento e ensinamento;

Para a professora Simone Reis, por tomar café comigo;

Para a arte contemporânea, por me dar um lugar;

Para os artistas “estranhos" e qualquer pessoa que viva seu corpo com a sua verdade;

e

em especial, um beijo para mim. 
Amigo mio... yo no soy lo que parezco. [...] El 'yo' que hay en mí, amigo mio, mora en la casa del silencio, y allí permanecerá para siempre, inadvertido, inadorable.

(Gibran Jalil Gibran, 1918) 


\section{RESUMO}

A presente pesquisa denominada Arte, Teatro Pós-Traumático e Loucura: O Processo Criativo do ChicQueiro e a Lógica do Pato, aborda os processos criativos para um trabalho artístico autoral poético da artista-pesquisadora Ingrid Abstrata Concreta Authora Desconhecida, a partir das influências do projeto Doida de Pedra: Arte e Loucura | Afeto e Afetações, realizado em locais de tratamento psiquiátrico com pessoas em atendimento. Este trabalho foi elaborado com o surgimento das práticas artísticas no Hospital Ulysses Pernambucano (HUP) em Pernambuco/PE, Hospital São Vicente de Paulo (HSVP) e Centro de Atenção Psicossocial (CAPS) da Região Administrativa de Taguatinga, ambos no Distrito Federal/DF. A dissertação estabelece uma relação azul do ser humano com o seu meio social, sua loucura, a maneira como experienciamos nosso corpo, com sua carga de memórias afetivas afetadas dentro de uma sociedade instinto.cio.(a)nalizada. Nesse projeto o corpo é visto como uma doença saudável e não como uma saúde sem doença. O corpo é patológico e pela Lógica do Pato é melhor não adoecer, porque não é normal a doença ter um corpo. Enquanto rodamos nossa saia cigana aos quatro ventos nós mostramos que não tem como viver sem se melar do outro, e assim a pesquisa discorre sobre o ser humano que é múltiplo, o in.diví.duo que é um duo dentro de um ser, é Sorbonóst, é arte, é artista da performance, é teatro sem personagem, Teatro Pós-Traumático, Processo Criativo do ChicQueiro de uma experiência corporal que se não dança não soa, não é sua.

Palavras Chaves: Arte, ChicQueiro, Lógica do Pato, Loucura e Teatro Pós-Traumático. 


\section{ABSTRACT(A)}

This present research named Arte, Teatro Pós-Traumático e Loucura: O Processo Criativo do ChicQueiro e a Lógica do Pato, surveys the creative process for an authoral and poetic artistic work created by the artist-researcher Ingrid Abstrata Concreta Authora Desconhecida, with the influences from the project Doida de Pedra: Arte e Loucura | Afeto e Afetações, done in some psychiatric treatment places with their patients. This work was elaborated alongside with the growth of the artistic practices at Hospital Ulysses Pernambucano (HUP) in Pernambuco/PE, Hospital São Vicente de Paulo (HSVP) and Centro de Atenção Psicossocial (CAPS) from the Região Administrativa of Taguatinga, both in Distrito Federal/DF. This dissertation establishes a blue relation of the human beings with their social environment, their madness, the way we experience our body, with all their affective memories affected inside a society instinto.cio.(a)nalizada. In this project, the body is seen like a healthy sickness, not like health without illness. The body is pathologic and by the Duck Logic, it is better to not get ill, because it is not normal for the illness to have a body. While we spin our gypsy skirt to the four winds, we show that we cannot live without getting ourselves dirty with the others, and thus, this research discusses about the human begin as multiple, the in.divídual that is dual inside oneself, which is also Sorbonóst, art, performance artist and theatre without characters, Post-Traumatic Theatre, ChicGsty Creative Process of a corporal experience that if our body does not dance, it doesn't sweat nor get pathetic affected inside a society instinto.cio.(a)nalizada.

Keywords: Art, ChicGsty, Duck Logic, Madness and Post-Traumatic Theatre. 


\section{LISTA DE IMAGENS}

Fig.01 - Ave Maria Santa Loca, Brasília, fev. 2016, foto La Conga Rosa P.29

Fig.02 - Trabalho realizado por Lucy, $30 \mathrm{~cm}$ x $5 \mathrm{~cm}$ x $7 \mathrm{~cm}$, Hospital Ulysses $\quad$ P.38

Pernambucano, set. 2013, foto Ingrid Kaline de Souza.

Fig.03 - Contenção física, jun. 2011, foto Autor Desconhecido. $\quad$ P.44

Fig.04 - LazúlI, Aldeia, set. 2013, foto Beth Moreira. $\quad$ P.45

Fig.05 - LazúlI, Aldeia, set. 2013, foto Beth Moreira. $\quad$ P.46

Fig.06 - Olhos, Hospital São Vicente de Paulo, abr. 2014, foto Ingrid Kaline de $\quad$ P.49

Souza.

Fig.07 - Ciganos de Luz, Recife, jul. 2014, foto Horst Lambert. P.56

Fig.08 - Ciganos de Luz DF, Brasília, out. 2014, foto Autor Desconhecido P.57

Fig.09 - Ciganos de Luz DF, Brasília, abr. 2015, foto Hmenon Oliveira. P.60

Fig.10 - Amostra Grátis, Hospital São Vicente de Paulo, maio 2014, foto Thalita P.65

Perfeito.

Fig.11-Eloucubrações: O Corpo é a Parte do Corpo Todo, Brasília, out. 2013,

P.67

foto Jacqueline Lisboa.

Fig.12 - Integração: Arte e Saúde Mental, Hospital Ulysses Pernambucano, jun. $\quad$ P.70

2015, foto Mariana Medeiros.

Fig. 13 - Haldol, Brasília, jul. 2015, foto Ingrid Kaline de Souza. P.78

Fig. 14 - Salam, Salame: Sim, One, Universidade de Brasília, jul. 2014, foto P.80

Márcio Hagih.

Fig. 15 - Salam, Salame: Sim, One, Universidade de Brasília, jul. 2014, foto

P.81

Natasha Padilha.

Fig.16 - Receita de Bolo Médica, Brasília, jul. 2014, Receita Médica. P.84

Fig.17 - Bula Comigo, Brasília, jul. 2014, Bula Médica. P.85

Fig.18 - Ensaio M\&Mz, From Hell With Love <3, Brasília, nov. 2015, foto P.105

Brennda Gabrielly.

Fig.19 - Ensaio M\&Mz, From Hell With Love <3, Brasília, set. 2015, foto Ingrid $\quad$ P.107

Kaline de Souza.

Fig.20 - Divulgação M\&Mz, From Hell With Love <3, Brasília, nov. 2015, foto

La Conga Rosa.

Fig. 21 - Apresentação M\&Mz, From Hell With Love <3, Brasília, nov. 2015, foto

La Conga Rosa.

Fig.22 - Apresentação M\&Mz, From Hell With Love <3, Brasília, nov. 2015,

foto La Conga Rosa.

Fig.23 - Apresentação M\&Mz, From Hell With Love <3, Ceilândia, nov. 2015, foto

La Conga Rosa. 


\section{SUMÁRIO DE URINA}

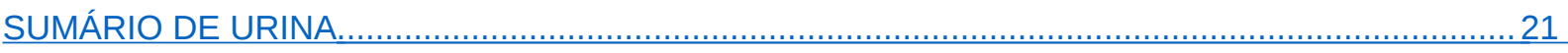

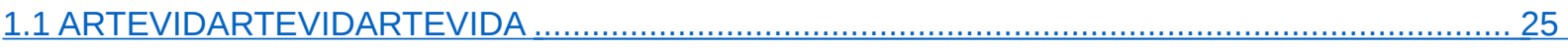

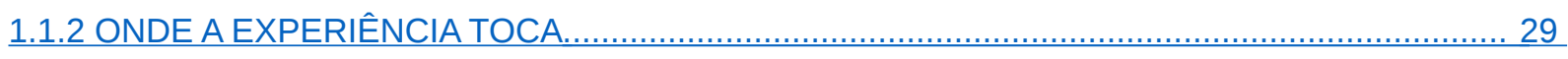

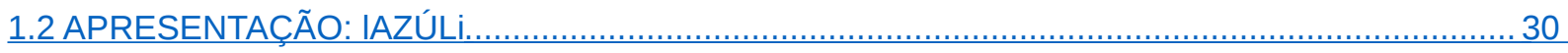

2. PATOLÓGICO: A LÓGICA DO PATO OU BAILA TU CUERPO ALEGRIA MACARENA $\ldots . . . . . . . . . . . . . . . .40$

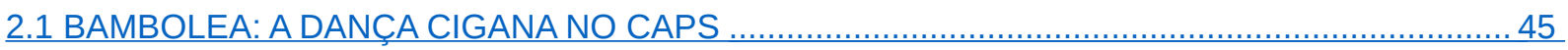

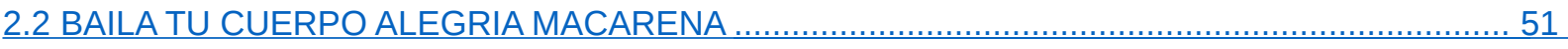

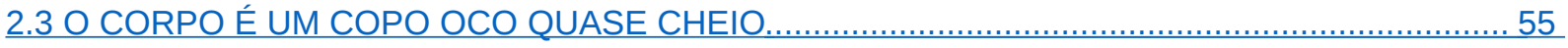

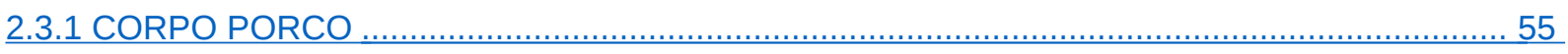

2.3.2 O CORPO É A PARTE DO CORPO TODO............................................................................ 58

2.3.3 - É UMA PLANTA QUE PARECE QUE SOBE DA RAIZ DE PÉ DE MAXIXE ……..................60

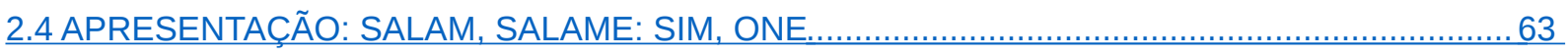

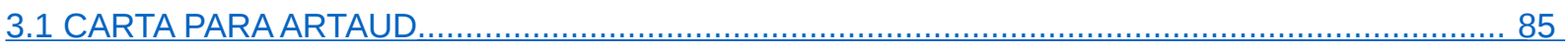

3.2 O PROCESSO CRIATIVO DO CHICQUEIRO …….................................................................. 90

3.4 APRESENTAÇÃO: M\&MZ, FROM HELL WITH LOVE <3 ……................................................ 95

CONCLUSÃO:

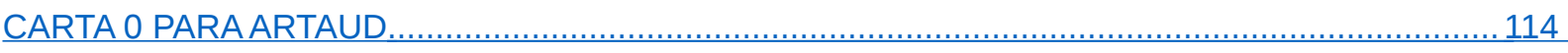

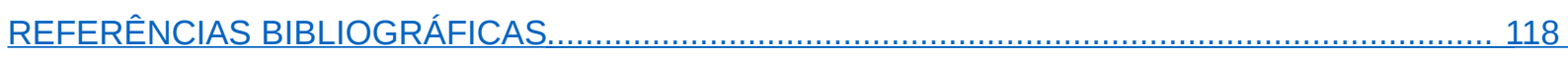

ANEXOS OU ARRIANDO OS TRABALHOS …………........................................................... 123 


\section{INTRODUÇÃO ou TUDO COM̌MÇOU HÁ UM TEMPO ATRÁS NA ILHA DO SOL ${ }^{1}$}

Eu e ela. Duas perdidas. Foi em uma viagem despretensiosa em 2012 ao Rio de Janeiro que perdida em Santa Tereza fui convidada por outra perdida na parada de ônibus, a ter a minha primeira experiência na área da saúde mental. Adentrei ao Espaço Cultural Laurinda Santos Lobo no mês de setembro quando acontecia o evento de arte e saúde mental Mostra de Arte Insensata. A mostra trazia trabalhos artísticos criados por pessoas que estavam em atendimento psiquiátrico e pessoas que atuavam na área, misturando, sem distinções, os trabalhos a fim de que o público não soubesse quem era de onde.

Vaguei pelos alojamentos do Centro Cultural e, às vezes, eu esbarrava nos funcionários da saúde mental, nos pacientes, nos artistas e nos transeuntes e não sabia quem era quem. Trocávamos conversas sobre os trabalhos artísticos ou simplesmente falávamos sobre as amenidades da vida. Nunca estive tão próxima de tantas pessoas que passam por tratamento psiquiátrico e, ainda mais, com pessoas que supostamente são tidas como "incapazes" em nosso meio social. Ali elas vendiam suas obras artísticas, lanches e faziam palestras. Não sei como explicar o encantamento, com o qual, daquele lugar. Foi nesse dia que me senti mais turista do que em qualquer outro espaço do Rio de Janeiro. Foi de fato um mundo que se abriu diante dos meus olhos.

Voltando para Recife entrei em contato com uma amiga psicóloga para tirar algumas dúvidas e com o Hospital Ulysses Pernambucano (HUP) para que pudesse realizar uma visitação e conhecer as instalações e rotina do lugar. Ir a um hospital psiquiátrico, em minha insegurança e ignorância pelo desconhecido, fazia meu coração sambar em corda, bamba. Visitei o Hospital em dia de evento artístico com roda de capoeira. Corpos se aproximam. Eu converso, mãos em meu cabelo, abraços. Alguém me leva até a roda de capoeira. Converso de novo, tontura. Conheço Elisabeth Rocha, funcionária do Centro de Atividades Terapêuticas (CAT). Observo a roda de capoeira, até um paciente entrar e mandar um hadouken ${ }^{2}$, tontura, abro um sorriso, tontura, eu rezo e vou embora.

\footnotetext{
${ }^{1}$ Referência da música Mila interpretada por Netinho.

${ }^{2}$ Poder de ataque de um personagem do jogo de vídeo game Street Fighter.
} 
Sento no banco de uma praça com as mãos no joelho, rezo, fico assustada e com vontade de voltar. A partir dali entro como voluntária nas aulas de teatro ministradas por Patrícia Barreto no Centro de Atenção Psicossocial (CAPS) do bairro de Casa Forte em Pernambuco. Retorno ao HUP com o grupo de dança cigana que integro em Recife, o grupo Ciganos de Luz. Vou pesquisando alguns autores que discutem sobre a relação de arte e saúde mental sendo eles Gilberto Safra, Gisele Pankow, Kris Ernst, Lula Wanderley, Nise da Silveira e Peter Pál Pelbart, vendo as obras de Antonin Artaud, Arthur Bispo do Rosário, Companhia Ueinzz e artistas que trabalham com a linguagem da performance como Jorge Glusberg, Maria Beatriz de Medeiros, Paul Zumthor e Renato Cohen.

Os livros foram fundamentais para conhecer mais essa área interdisciplinar, mas na medida em que os livros falavam comigo eu me afastava cada vez mais da presença do hospital psiquiátrico. Deixei os livros ao lado da cama, me afastei do CAPS e me voluntariei no HUP. No HUP, participei da Oficina de Argila ministrada por Christina Machado. A princípio, eu me sentava afastada da grande mesa com argila, tendo os olhos dentro das mãos de cada um que ali trabalhava, passei dias observando o trabalho de Machado e das estagiárias com os internos. Aos poucos, fui sendo convidada, pelos pacientes para estar mais próxima. Às vezes, era apenas na presença, outras tentava estimulá-los. No geral, eu ficava surpresa com as coisas que eles me diziam sobre seus trabalhos e sobre a vida.

Algo ainda me faltava. Iniciei então a Oficina de Expressão Corporal para os pacientes internos do HUP, as oficinas aconteciam uma vez por semana com duração de $1 \mathrm{~h}$ cada. Resgatei minha vivência no teatro para elaborar atividades que pudessem liberar a tensão nos corpos dos pacientes além de realizar aplicação de Reiki. A oficina acontecia em meio a imprevistos, entre interrupções, momentos mágicos ou mudanças no programa da oficina. Foi neste período que eu perguntava aos pacientes “O que é corpo?”, com a intenção de poder entender como eles se viam e até para que eu pudesse me entender.

Paralelo à Oficina de Expressão Corporal, coloquei em prática o evento mensal chamado Internação: açõesperformáticaspradoidover que logo depois se chamaria Integração: Arte e Saúde Mental. Iniciado em 2013 até os dias de hoje, o evento, que acontece de maneira voluntária, mensal, gratuita, leva artistas interessados em partilhar de sua arte para o HUP. O evento acontece com a intenção de que outras pessoas possam, nem que seja por um momento, mudar suas visões sobre o paciente psiquiátrico, perceber o enclausuramento do 
ambiente hospitalar psiquiátrico e como nossa visão de mundo se modifica quando aceitamos outros corpos e outras maneiras de viver a vida. A partir daí surgiu o projeto Doida de Pedra: Arte e Loucura | Afeto e Afetações, que agradeço ter caído no meu colo e que por tantas noites me colocou para ninar. E então, dando continuidade ao Doida de Pedra na cidade de BrasíliaDF, o projeto adentrou ao Centro de Atenção Psicossocial (CAPS) Região Administrativa de Taguatinga e Hospital São Vicente de Paulo com aulas de dança cigana e a mostra artística semestral Amostra Grátis.

Estabelecendo um contato próximo às pessoas que realizam tratamentos psiquiátricos, foi percebido que alguns pontos da minha prática artística sofriam alterações. Uma delas é uma maior colocação do meu corpo; a abertura da minha prática para que pessoas interessadas participassem, não apenas artistas; a despreocupação com o material de cena, tendo em vista que, muitas vezes, pode não dar certo a utilização no momento da apresentação, mas nem por isso essa deixa de acontecer e não há necessidade de enrijecer o corpo por raiva devido a um planejamento falho. O que interessa é um corpo que pulsa e pula, que usa glitter pós-carnaval. Com essa experiência pessoal, que resultou em outra maneira de me expressar artisticamente, houve a necessidade de por em palavras as coisas que me tocavam, realizando esta pesquisa de trabalho autoral poético.

Esta dissertação é trabalhada em três capítulos e anexos com as imagens das apresentações e entrevistas realizadas pela artista-pequisadora. O primeiro capítulo é dividido em três partes, na qual abordo memórias afetivas afetadas das minhas experiências de vida, o processo criativo e a apresentação $l A Z U ́ L i$ que permeia as experiências psiquiátricas e a minha saúde mental. Trago alguns autores como Fayga Ostrower, Jorge Larossa, Lygia Clark, Maria Beatriz de Medeiros, Nicolas Bourriaud e Umberto Eco que me auxiliam a discorrer sobre a ideia do ser humano de ser fruto do seu meio, cabendo a ele transformar sua realidade de maneira criativa, já que é, do sujeito, a criação, bem como do direito do outro, acolher ou rejeitar aquilo criado.

Ainda dentro deste capítulo, com $l A Z U ́ L i$, relato minha experiência com a depressão, os primeiros contatos com a psiquiatria e a necessidade de mostrar em meu corpo a minha contenção física. Amir Haddad, Guilhermo Gomes-Peña, Lula Wanderley e Susan Sontag foram fundamentais para escrever este ensaio poético, pois me trouxeram o contexto do experienciar o corpo como ferida aberta e que esta ferida não precisa ser tampada, ocultada, 
ou negada. A nossa ferida também é dor de mundo e o seu remédico ${ }^{3}$ não vende em farmácia.

Abro as grades do segundo capítulo falando sobre a patologia, a experiência no CAPS com a dança cigana, as usuárias do local e o corpo e a apresentação artística Salam, Salame: Sim, One. Início com o conceito de que o patológico é a Lógica do Pato. O Pato, enquanto médico de práticas abusivas, como dono da vida do outro, interfere com suas ferramentas no aprisionamento dos corpos por via medicamentosa. Meu embasamento é com David Le Breton, Franco Rotelli, Guilhermo Gomes-Peña, Peter Pál Pelbart e Susan Sontag. Estes autores se fazem relevantes na dissertação, pois trabalham a relação corpo e dor, saúde e doença e controle social, colocando o olhar médico como placebo. No tópico seguinte, elaboro as experiências corporais com a dança cigana e as alunas do CAPS, contando como se deu o processo dessas mulheres ao permitir que se expressassem pelo corpo mais do que pelas palavras, utilizando a dança cigana para descarregar suas tensões.

Prossigo na escrita com Alejandro Jodorowsky, Antonin Artaud, Gilberto Safra, Gisele Pankow, Michel Serres e Susan Sontag para falar sobre o corpo enquanto ChicQueiro. Aquele que é cria do meio social e o corpo criativo a partir da doença. Realizo um apanhado de referências corporais, obtidos com os pacientes durante as atividades em hospital psiquiátrico. Assim elaboro um pensamento de que vivemos em uma sociedade instinto.cio.(a)nalizada que não se permite viver às sombras do seu corpo e gera uma saúde adoecida. Sem a auto aceitação, o ser humano passa por cima do seu processo de maturação. Com a apresentação Salam, Salame: Sim, One é exposto o adoecimento azul, que também sofre o meio artístico ao rotular, restringir, excluir outras formas de expressão corporal. Aqui se entra em contato com a medicação psiquiátrica como mote para uma prática artística.

Esta pesquisa faz um trajeto que trabalha o processo criativo da arte vida e a influência do meio social nas experiências corporais do ser humano, o corpo como regenerador e como socialmente fa(r)dados a anestesiar a não doença do corpo. Esses dois capítulos são importantes para se chegar ao último capítulo desta dissertação que aborda o Teatro PósTraumático enquanto tratamento do ator vivido por um Processo Criativo do ChicQueiro. Um teatro frouxo, um teatro de imprevistos, de relações corporais do brega, do grotesco, do kitsch, do nonsense, um teatrinho com produçõezinhas de artinha contemporâneazinha. Um corpo em Sorbonóst de in.divi.duos para artistas sem personagens, mas personas, ou melhor,

\footnotetext{
${ }^{3}$ Para este trabalho a palavra "remédio" será substituída por remédico.
} 
identidades performáticas. Aqui utilizo Alejandro Jodorowsky, Antonin Artaud, Gilberto Safra, Michel Serres, Mikhail Bakthin, Katharina Pewny, Peter Brook, Tadeusz Kantor, que me auxiliam a abraçar o ilógico, o irreal, o estranho, o corpo outro/outros de mim, o corpo infantil, o teatro onde o papel é apenas um papel e eu não preciso me encaixar em um formato A4. O ChicQueiro é o corpo que tomou banho, passou colônia de lavanda e foi se lambuzar na lama. Finalizo o capítulo com a pecinha de teatrinho pós-traumático $m \& m z$, from hell with love $<3$. Em que tento encontrar um corpo para a ideia do Teatro Pós-Traumático a partir da peça de Heiner Müller, Quarteto. 


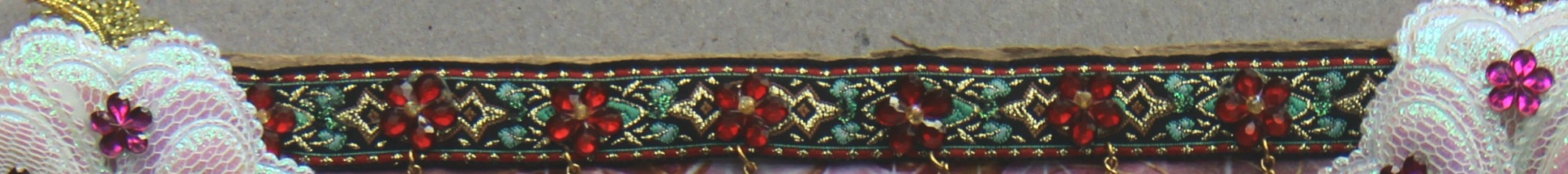
(2)

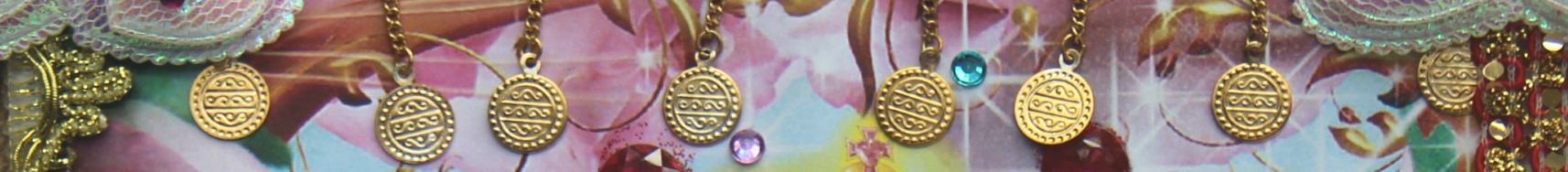
(1)

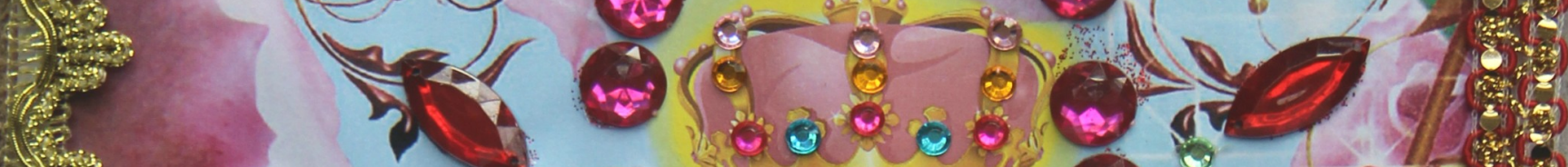

$\frac{1}{2}+3$

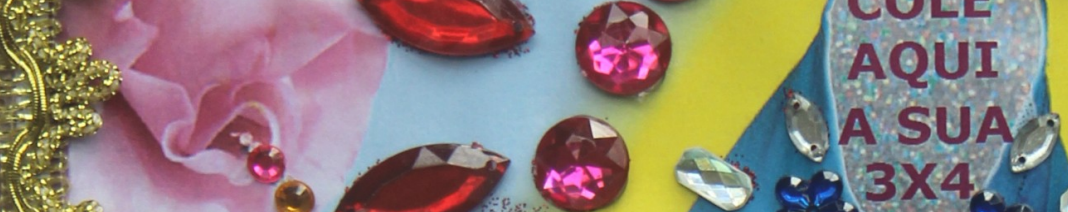

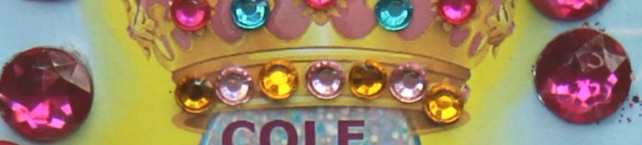
3

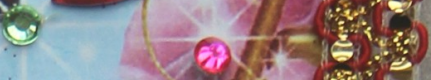
a $(1,5)$

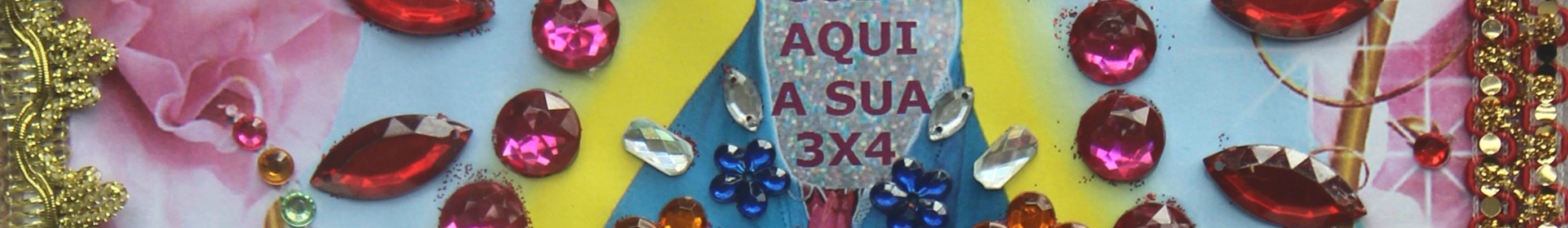

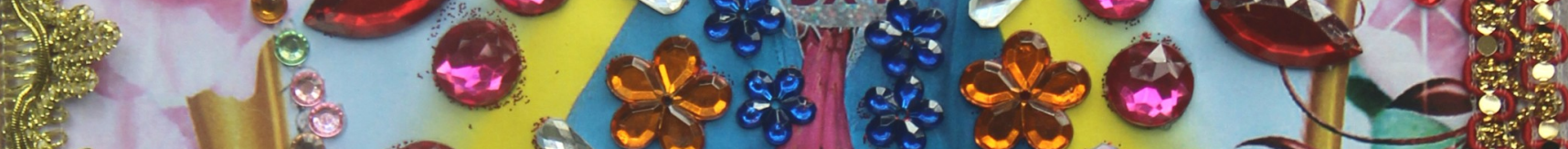

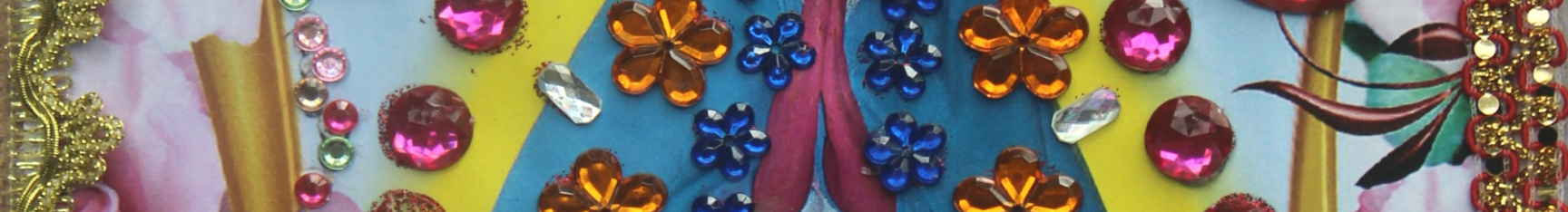

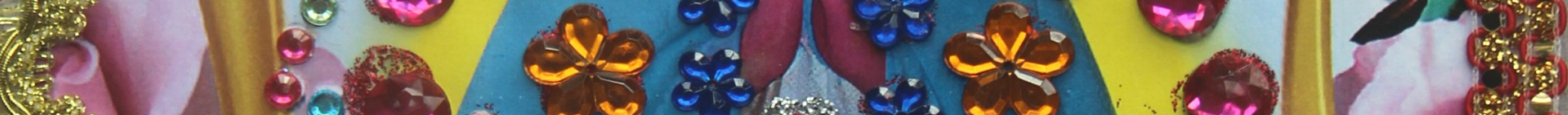

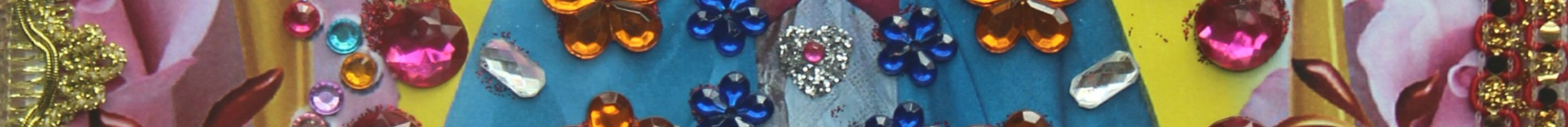

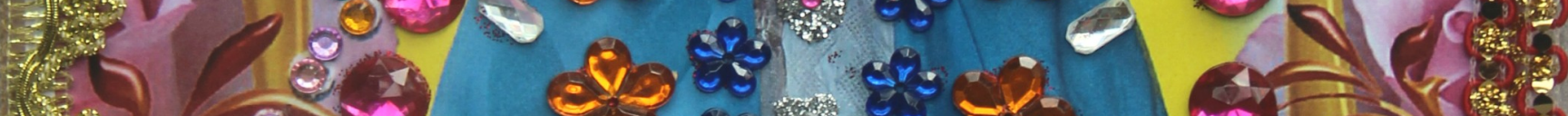

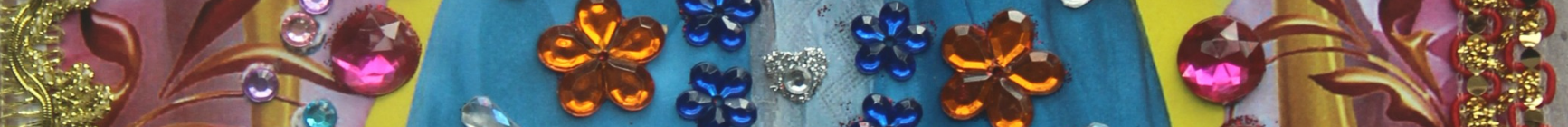

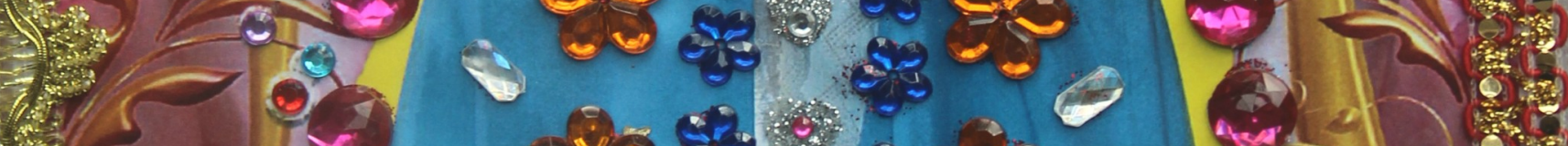

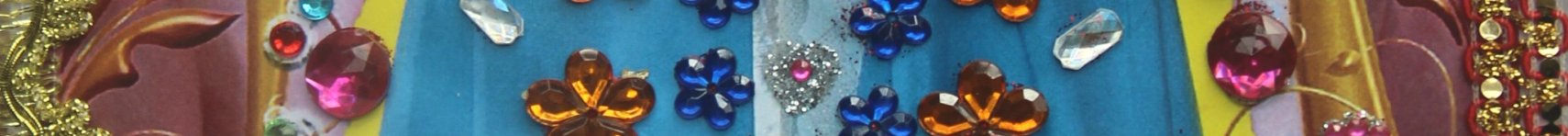

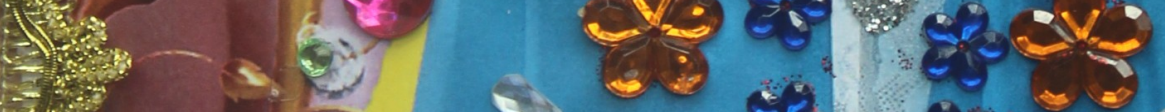

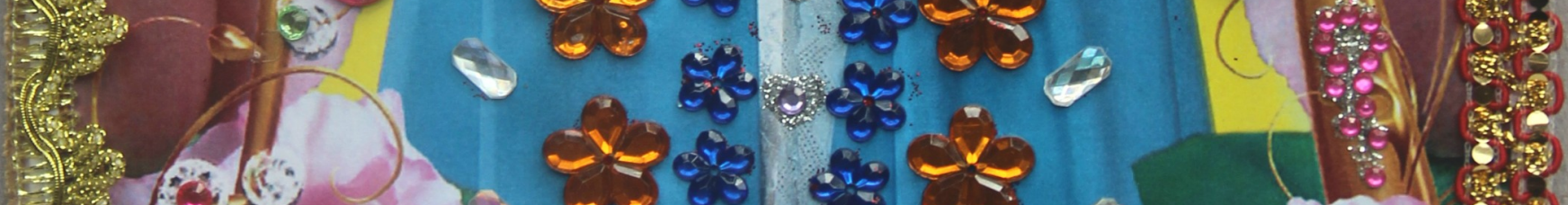

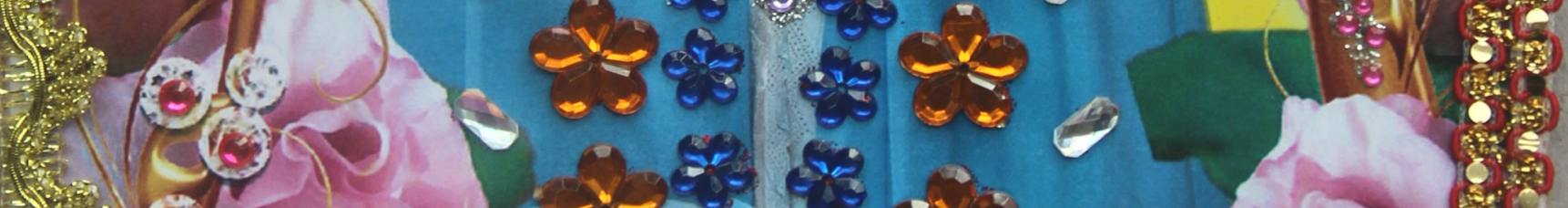
Fe (3)

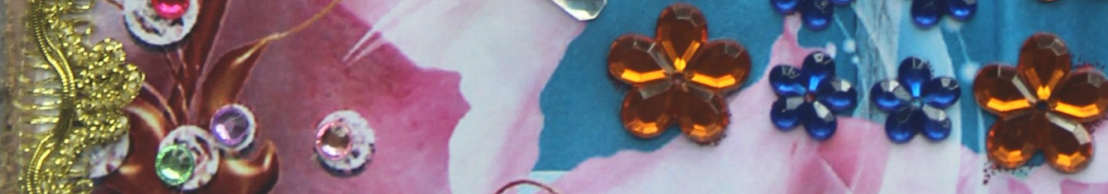
(1) 802

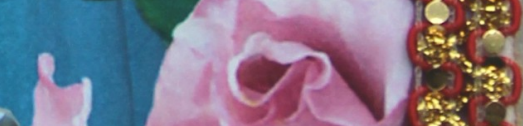




\title{
1. O PROCESSO CRIATIVO NOSSO DE CADA DIA ou CANTA PARA DESCER ${ }^{4}$
}

\author{
Nome: Ingrid Princesa do Deserto ${ }^{5}$ \\ Data de Nascimento: No dia em que a terra parou ${ }^{6}$ \\ Endereço: Na rua, na chuva, na fazenda, numa casinha de sapê $\hat{~}^{7}$ \\ Filiação: Mainha, Painho eu gosto dele ${ }^{8}$
}

E nessa loucura de dizer que me quero ${ }^{9}$, vou afirmando as minhas neuroses, as minhas histerias, meus transtornos afetivos, meus vícios e desejos psíquicos. Vou sendo a criança de Leão, com Ascendente em Touro e ora merda, Vênus em Virgem.

Desde que sai da vagina pentelhuda de mainha e fui vista pelos dois buracos negros de painho, uns disseram que eu não iria dar em nada, outros pensaram que seria um caso perdido, mas por não poder enganar o meu coração, eu sei que me amo! E chega de mentiras ${ }^{10 !}$ Admito, pelo banho de Monange da Xuxa ${ }^{11}$, que desde as canções bregas uivantes e as aulas de matemática com painho sobre meu couro assado, que um mais um virou zero a, craseado, esquerda. Desejei perante Allah, em meus oito anos, que ele saísse da nossa humilde residência ${ }^{12}$. Não durou três solstícios para sair da tua vida de cabeça erguida coisa que você não fez, já chorei demais, agora vem a sua vez, acho que vai ser melhor para todos três, ${ }^{13}$ sentiu mainha. Fiquei sozinha. Bem abstrata, assolada pelo corredor fúnebre de nossa casa, com tardes vazias e grades nos olhos sendo eu e meu som. Eu e Britney Spears, Eliana e Chiquititas.

Indicadores, indicadores ${ }^{14}$ apontaram na adolescência suspeita de depressão. Naquela época, fui uma órfã com pai e mãe, mais mãe do que pai e menos pai do que a dupla sertaneja. Não que nada não fosse feito, era. Só que presa numa casa vivendo de solidão, eu me encontro aqui mais uma vez me enchendo de inspiração, então eu desabafo as mágoas as tristezas

\footnotetext{
${ }^{4}$ Referência a cultos religiosos Umbanda e Candomblé.

${ }^{5}$ Nome me dado por Geni quando interna no Hospital Ulysses Pernambucano.

${ }^{6}$ Todas as músicas estão referenciadas no fim desta dissertação. Canção O Dia em que a Terra Parou. Interpretada por Raul Seixas.

${ }^{7}$ Canção Casinha de Sapê. Interpretada por Hyldon.

${ }^{8}$ Canção Mainha, Painho. Interpretada por Companhia da Lapada.

${ }^{9}$ Canção Evidências. Interpretada por Chitãozinho e Xororó

${ }^{10}$ Idem.

${ }^{11}$ Apresentadora de programa infantil que realizava propaganda de hidratante para pele da marca Monange.

${ }^{12}$ Canção Humilde Residência. Interpretada por Michel Teló.

${ }^{13}$ Canção Saí da tua Vida. Interpretada por Reginaldo Rossi.

${ }^{14}$ Canção Dedinhos. Interpretada por Eliana.
} 
neste violão, parece que ele chora com pena desse coraçãoooo ${ }^{15}$.

- Mudei de nível do Mario Bros ${ }^{16}$, cara. - Voz do além que pensa em voz alta.

As histórias delirantes começaram a entrar pela janela fechada do meu dia-a-dia. No meu silêncio barulhento e na minha santa vitamina de banana das manhãs since 1993. Carreguei nas costas minha cama e a tristeza de não ter visitas, de ao me expressar ser vista torta, de estar, sempre, eu e meu som. Eu e meu pop/punk/glam/rock/trip hop/emo/love songs. E só lamento se não agradou aos vizinhos. Eu também não gostava de decorar com os olhos as paredes brancas do meu quarto. Loucura não se passa na cabeça. Loucura não passa.

- Por obséquio, alguém explica isso? - Voz que mostra um leve irritamento.

Com esta entrada triunfal, jurei pelo meu Cavalo de $\mathrm{Fogo}^{17}$ que meu corpo seria many-festado, mani-festa-ação $0^{18}$, pois nesta vida não haveria a possibilidade em ser apenas uma. $\mathrm{O}$ individual, ainda assim, é dual ${ }^{19}$. Sempre do outro, sempre com o outro, parte do outro, a partir do outro, parido por outro, o outro ou tu? Ou nós. O "ou" ou "e" ${ }^{20}$. Ficar no meio sempre foi um atropelo por soluços. But, o outro, os outros de mim, tão alheios, ainda sem nome, figura concreta, lombrigas, emergiam do mangue e me fascinavam, pelo simples toque de me entender e me permitir ser só(mente) muitas.

Entender isto me custou risos de gente que nem o nome sabia. Mas uma coisa era entendida: O Corpo é Porco e se ele pode se sujar, que nem o Omo Progress ${ }^{21}$ seja capaz de tirar as manchas mais difíceis. Este é o corpo que entendo como meu: algo espontâneo, frágil e entregue aos tantos outros de mim e aos tantos outros dos outros que é melhor me segurar senão eu caio ${ }^{22}$.

São com esses encontros "eus", às vezes atropelados e outros cicatrizados, que pode sensibilizar e permitir experienciar outros corpos, em seus excessos e em suas faltas. É nessa queda livre que os riscos viram arranhos, que se pega o troco errado e o ser pode virar bolha... E que se exploda! A Vitória de Samotracia ${ }^{23}$ estava certa ao perder a cabeça. Cinco quilos

\footnotetext{
${ }^{15}$ Canção Vivendo de Solidão. Interpretada por Limão com Mel.

${ }^{16}$ Jogo eletrônico.

${ }^{17}$ Desenho animado de 1986.

${ }^{18}$ Medeiros (2011, p.16).

${ }^{19} \mathrm{O}$ conceito de in.diví.duo será melhor apresentado no decorrer da dissertação.

${ }^{20}$ Conceito de "e" em anexo na entrevista com Lula Wanderley, 2014.

${ }^{21}$ Marca de sabão em pó.

${ }^{22}$ Canção Me Segura Que Senão Eu Caio. Interpretada por Alceu Valença.

${ }^{23}$ Escultura de mulher alada sem sua cabeça. Exposta no Museu do Louvre em Paris.
} 
acima do pescoço são iguais a cinco pacotes de arroz Camil de tarja amarela. Ah! A sabedoria dos que perdem a cabeça e continuam voando... É nessa liberdade que quero submeter o meu artístico. Mentira. A rua é como um grande hospital a céu aberto, local de encontros imprevisíveis. Sabe nada inocente ${ }^{24}$. É na intensidade do asfalto, do chão batido, nas nuvens dilatadas que a Vitória-Sem-Cabeça passeia com um largo sorriso no rosto. Nem todo encontro é encontrado, nem todo nó é amarrado e nem todo homem tem saco.

Nos becos sem saída o bobo fica. Merteuil ficou sem Valmont ${ }^{25}$, Bochecha sem Claudinho, sou eu aqui sem você ${ }^{26}$, que deixou de colocar a cabeça para fora das gaiolas, que fica colocando barras no meio dos textos, que não apareceu no dia da sua posse, porque se fosse comigo e se essa rua fosse minha eu mandava ladrilhar ${ }^{27}$. O encontro pode ser silencioso por fora e cidra Cereser por dentro, ser mais uma espécie de comida japonesa que, no momento de sua despedida, o som feito no espaço, possa caber no bolso do peito. Aí nós voltamos outros para outros, pois sempre ceresemos de outros.

O mundo é imundo e não é meu, é nosso, tão nosso que muito se vive nele com sentimentos de propriedade que vai além dos territórios demarcados em terra. O corpo do outro vira tão desejoso, pecaminoso, por leis feitas por outros de outras épocas. Vive-se em tantos lugares, ainda no passado, como bóia salva-vida. A mudança pede por andanças e nessa época de fast food não é todo mundo que consegue se desentalar. As relações deixam um pouco de ser entre pessoa e pessoa, passam a ser pessoa e poder vs. pessoa e poder. Um poder murcho, sem carinho, sem ficar guardado no seu coração, na noite fria solidão, saudade vai chamar ${ }^{28}$ por misericórdia, você vai ver ${ }^{29}$. Ainda assim, se diz que isto é loucura. Isto não é loucura, é desrespeito, falta de noção, arrogância, cultura, tradição, oriental, ocidental, arriba e abajo. Loucura é um "e" de saúde mental.

Loucura dá na ponta do dedo mindinho do pé direito quando vai de bicuda diagonal na parede. Dá no pé de manga quando a fruta vem bem docinha e os fiapos ficam todos grudados entre os dentes. Dá em homem, mulher, quem não é nenhum dos dois, criança e até em velho. Dá na Morte e Vida Severina e até na cachorra Baleia ${ }^{30}$. Loucura não enlouquece sozinha.

\footnotetext{
${ }^{24}$ Frase de Compadre Washington, integrante da banda de axé: É o Tcham.

${ }^{25}$ Personagens do livro Ligações Perigosas de Chordelos de Laclos e da peça Quarteto de Heine Muller.

${ }^{26}$ Canção Fico Assim Sem Você. Interpretada por Claudinho e Bochecha.

${ }^{27}$ Canção popular.

${ }^{28}$ Canção Você Vai Ver. Interpretada por Zezé di Camargo e Luciano.

${ }^{29}$ Idem.

${ }^{30}$ Texto de João Cabral de Melo Neto. A cadela da trama chama-se Baleia.
} 
Não se cria, já vem na Corrida Maluca ${ }^{31}$ dos espermatozoides camisa de força e, quando alcança o objetivo, libera geral ${ }^{32}$. Loucura se compra no mercado naquela promoção sem noção. Loucura não veio para ser curada porque ela não é doença. Não está na grama do vizinho, está nos meus olhos que a veem mais verde. Não morre, vira mito purpurinado ${ }^{33}$. Não se morre de loucura, mas o povo adora matá-la. Loucura não se encontra no fundo de garrafa em mesa de bar. Não fica prensada em papel de Bíblia.

Loucura é de comer - sempre o outro. Loucura não é de lua é de 365 às vezes 366 dias. Loucura insana é usar de desculpas para escondê-la. Loucura é simplesmente não gritar quando se consegue o que tanto quer. Não é deixar as lágrimas rolarem, é fazer represas sempre maiores. Loucura não é vendida em caixinhas nas farmácias porque ela é tão benéfica que love is in the air ${ }^{34}$. Não tem atestado porque não precisa de assinatura. Loucura se percebe no olhar adocicado dos apaixonados e este amor é tão grandeeeee ${ }^{35}$. Loucura é misturar café com canela, é beijar devagar debaixo da chuva, é dançar até entrar em transe. Loucura é. É sorrir e só rir. Loucura mora no templo de cada um. Loucura quando mais louca melhor. Dá para pegar, dá para abraçar, dá para beijar, é só chegar. Loucura usa mais ingredientes do que feijoada. É sentir o corpo vibrar... O resto, que dizem que é loucura, é intriga da oposição. Não tão ao pé da letra porque a bondade não vem a galopes.

Enquanto não nos percebemos em uma sociedade medicada, na doença, seres de porcelana, castelo de areia, se continua a caminhar construindo fortalezas solitárias cada vez maiores para ser nosso abrigo. O corpo, independente de seu tamanho, machuca e, quando o faz propositalmente, destrói. Em um hospital temos os que são pacientes, os impacientes, os familiares e os funcionários. A única diferença é que nesses dois últimos, a patologia, determinada por um patológico estudado, ainda não assolou o sossego. Recordar é viver: A doença dorme em nossa cama e se não fosse por ela não teríamos o sentido de cura ${ }^{36}$.

As doenças não se atêm a um pedaço de papel carimbado cheio de composições químicas. Já nascemos doentes, do corpo, do espírito. Ninguém escapa da doença e que ela não vá com Deus porque o amor ainda está $a q u i^{37}$. Meu corpo do(ente) ${ }^{38}$ percebe o seu tão doente quanto

\footnotetext{
${ }^{31}$ Desenho animado Corrida Maluca de 1968.

${ }^{32}$ Canção Libera Geral. Interpretada por Xuxa.

${ }^{33}$ Referência ao bordão "Bicha não morre, bicha vira purpurina" da personagem Vera Verão no programa televisivo $A$ Praça é Nossa.

${ }^{34}$ Canção Love is in the air. Interpretada por John Paul Young.

${ }^{35}$ Canção Estou Apaixonado. Interpretada por Daniel.

${ }^{36}$ A visão de cura para este trabalho será melhor apresentada com o decorrer da dissertação.

${ }^{37}$ Canção Vá Com Deus. Interpretada por Roberta Miranda.

${ }^{38}$ Intervenção feita pela artista Maria Eugênia Matricardi ao ler o texto.
} 
e no meio dessas doenças nos reconhecemos necessitados. Neste ponto nos vemos como gente e quando chegamos a este ponto as relações afetivas e afetadas acontecem e o ponto deixa de ser ponto e passa a estar entre aspas. Porque a doença é o que causa o encontro-incomodo. É, na doença, que eu sinto muito.

É por isso que como uma deusa nós nos mantemos $^{39}$. Deuses e deusas de língua azul, de rugas que escorrem pelos cantos dos olhos, com ideias mirabolantes, seres inanimados de cabelos naturalmente oxigenados e corpo festivo. Até os deuses amam. Não tem para onde fugir. Som de trompete, sanfona, dança esquisita. A música convida para tu Tarzan levar a mim $^{40}$ louca, levar a louca, levar a louca pra dançar. Chegue, chegue, chegue ${ }^{41}$. Que a festa é sua, a festa é nossa é de quem quiser, quem vier ${ }^{42}$. E que venham todos, segurando na mão da negra $\operatorname{Sara}^{43}$, vamos serelepes serelebrar o que sentimos! Um doido não assumido é doído. Coragem irmãos, bons ventos virão

ou não.

Eparrêiiiiii!

Iansã!!!

\subsection{ARTEVIDARTEVIDARTEVIDA}

A arte dos primitivos, a arte coletiva das comunidades, a arte para os mecenas, a arte trabalho, a arte das elites, a arte que alguém reconheceu e, então, foi vista como arte, a arte dos produtos, a arte do suspiro para um desenho, a arte transfigurada, a arte do corpo, a arte sem corpo, a arte das interrogações, a arte das curas incansáveis. "Escrever sobre arte é uma contradição: a arte não pode ser dita.” (MEDEIROS, 2005, p.15). Contradição. Contra dicção. Com tradição a arte de escrever sobre a arte e por em palavras objetivas as experiências de devaneios.

Não tenho referência bibliográfica ou citação fiel, apenas uma lembrança da época de escola, dos meus 13 anos, da aula de literatura e de Jean-Jacques Rousseau, com a ideia de sermos frutos do meio. Por via da sociabilidade, das relações e das construções enquanto ser, boa parte das produções artísticas e estilos estéticos pode se tornar norteado pelas inquietações de uma subjetividade delirante. Judd (2006, p. 97) nos lembra que "O motivo para mudar é sempre algum desconforto: nada que nos instigue à mudança de estado, ou a qualquer ação nova, mas algum desconforto". O próprio desconforto já é uma alteração de estado e já nos pede uma ação outra, que, para os que se expressam nas simbologias de um fazer dito desarrazoado, estas práticas artísticas emergem e a partir delas pode-se compreender, ou não,

\footnotetext{
${ }^{39}$ Canção $O$ Amor e O Poder. Interpretada por Rosana.

40 "Mim Tarzan, tu Jane" frase do filme infantil Tarzan, o Filho das Selvas

${ }^{41}$ Canção Levada Louca. Interpretada por Ivete Sangalo.

${ }^{42}$ Canção Um Novo Tempo. Interpretada por Cecilia Dale.

${ }^{43}$ Santa Sara Kali. Santa padroeira dos ciganos.
} 
uma parte de si.

O processo da arte vida, sem interferência de conjunções, preposições e travessões que separe o termo, leva a perceber o quanto de vida tem a arte e quanta arte tem a vida, sem que o processo criativo seja limitado e delimitado pelo campo artístico. Clark (2006, apud Millet 1992, p.20) "Por Deus, a vida é sempre para mim o fenômeno mais importante, e esse processo quando se faz e aparece é que justifica qualquer ato de criar, pois há muito a obra para mim é cada vez menos importante e o recriar-se através dela é que é o essencial”. Alguns processos criativos vêm a ocorrer primeiramente durante as possibilidades de vida, para que a partir da experiência possa jorrar pela arte, pelos olhos, pelos poros, pelos traumas ou pelos.

\begin{abstract}
A única coisa a dizer sobre a arte e a vida é que a arte é a arte e a vida é a vida, que a arte não é a vida e que a vida não é a arte. Uma arte 'parte-da-vida' não é melhor nem pior do que uma vida 'parte-da-arte'. As belas-artes não são um meio de 'ganhar a vida' ou um 'modo de viver a vida', e um artista que dedica a vida à sua arte ou a sua arte a sua vida sobrecarrega a arte com a sua vida e a sua vida com a sua arte. A arte que é uma questão de vida ou morte não é nem bela nem livre. (REINHARDT, 2006, p. 74)
\end{abstract}

Mesmo a arte e vida e vida e arte se mostrando em posicionamentos distintos, ainda assim elas podem beber uma no copo da outra. O ser criativo transita entre estes dois espaços. O ser humano abre fendas em seu cotidiano que permite com que ele se expresse criativamente, já no Hospital, em uma área institucional medicamentosa, não há tempo para isso. O processo criativo, quando realizado junto a objeto estético, pode vir a ser para aquele que cria um estralo para as suas necessidades e um amadurecimento na sua mão-de-obra, "O homem" ${ }^{44}$ cria, não apenas porque quer, ou porque gosta, e sim porque precisa; ele só pode crescer enquanto ser humano, coerentemente, ordenando, dando forma, criando". (OSTROWER,1977, p. 10). Este ser humano criador recebe percepções de mundo, modifica, adapta e reage a ele, expondo uma relação afetiva afetada pela experiência como um todo. Bourriaud (2009, p.30) coloca que "Não existem formas na natureza, no estado selvagem, porque é nosso olhar ${ }^{45}$ que as cria, recortando-as na espessura do visível”. O que torna um artista artista não é primeiramente a sua obra, mas a sua intenção em ser artista. É o sair do armário e se assumir como Obreiro de Deus ${ }^{46}$, aquele que constrói obras partindo de si e de suas relações.

Durante a Oficina de Argila em 2013, ministrada pela artista Christina Machado, no Hospital Ulysses Pernambucano (HUP) na cidade de Recife, um dos participantes da oficina, ao

\footnotetext{
${ }^{44}$ Grifo nosso. As citações que possuírem a palavra homem para designar ser humano serão tachadas.

${ }^{45} \mathrm{O}$ que o Pato vê o coração não sente.

${ }^{46}$ Partindo da ideia de religiões orientais de que nosso corpo é divino e faz parte do que se entende por Deus.
} 
finalizar a modelação de seu trabalho, me olha e preenche o vazio da sala dizendo que era um artista. Este participante ao me dizer que seu trabalho caracteriza-se como arte e que ele a produz independente da formalização, me leva a acreditar e aceitar que ele é um artista, não por ser um participante que passa por um tratamento psiquiátrico, mas porque temos possibilidades de vida e assim temos o direito de assumir, ser e viver esta potência de nosso corpo da forma que nos convêm. Já Lucy, outra participante do local, realizava esculturas de cavalo sem nunca ter manuseado a argila, seu trabalho era bem desenvolvido e sensível, aos meus olhos, e ela não se afirmava enquanto artista. Seu trabalho pode ser visto na Fig. 02.

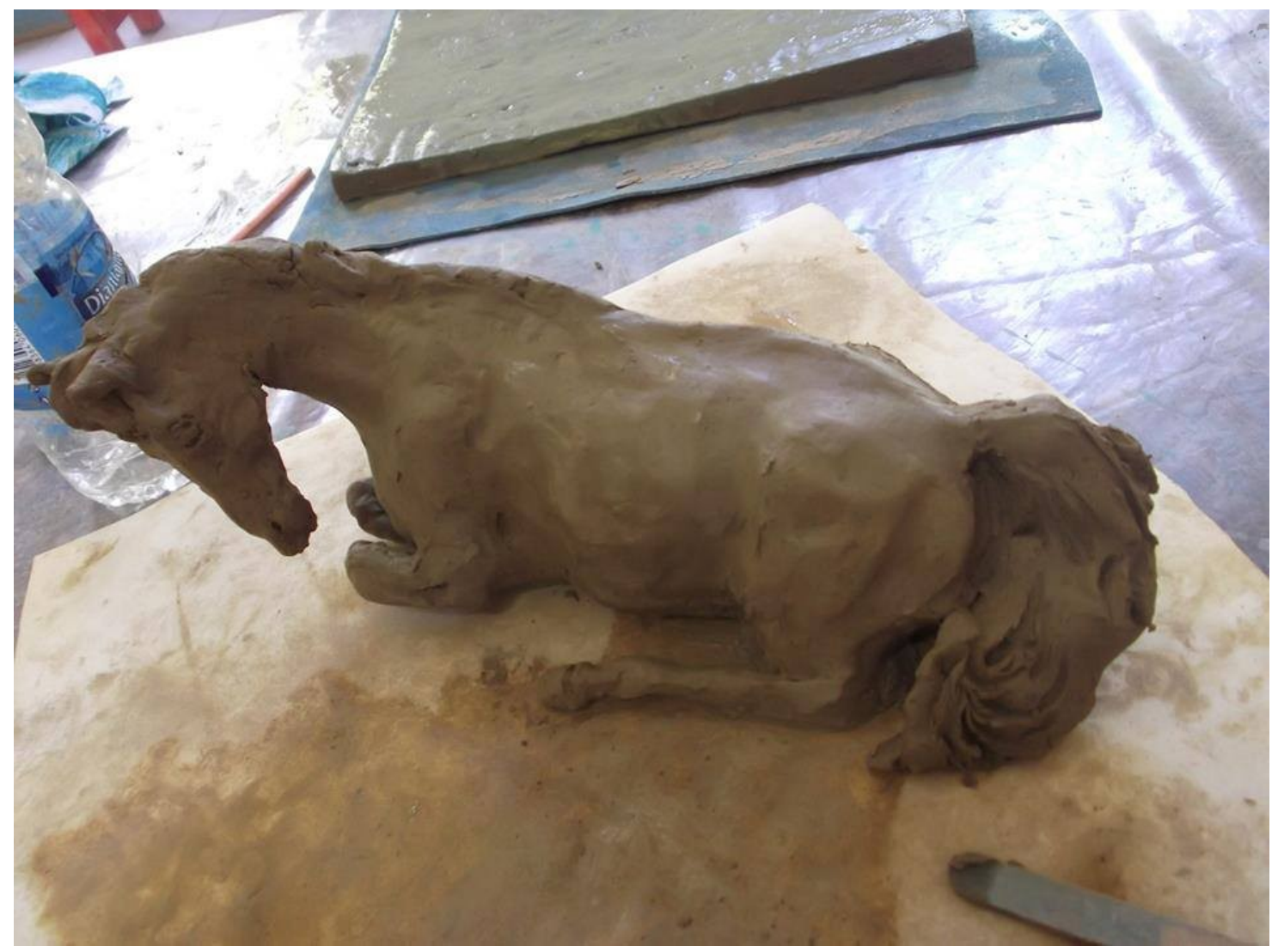

Fig. 02 - Lucy nunca tinha trabalhado com argila antes.

O processo criativo se apresenta no jogo do artista com sua obra e no jogo com o público. $\mathrm{Na}$ exposição de Christina Machado ${ }^{47}$, Minha Cabeça Nossa Natureza, na Galeria Janete Costa em Pernambuco, enquanto eu reparava os materiais de escultura de barro realizada por pessoas em tratamento psiquiátrico do HUP escuto de um homem que a exposição só era feita porque os participantes eram loucos. Como Medeiros (2005, p. 31) comenta "Para que algo seja designado arte, faz-se necessário imersão no prazer, ou desprazer, e esse será individual com direito à palavra”. Nome.ações. A arte dá prazer. A arte dá desprazer. A arte dá. Quando estamos diante de uma obra estamos em casal.

\footnotetext{
${ }^{47}$ Esta exposição é em referência ao seu trabalho no Hospital Ulysses Pernambucano.
} 
Uma obra de arte possui uma qualidade que a diferencia dos outros produtos das atividades humanas: essa qualidade é sua (relativa) transparência social. Uma boa obra de arte sempre pretende mais do que sua mera presença no espaço: ela se abre a diálogo, à discussão, a essa forma de negociação inter-humana [...] (BOURRIAUD, 2009, p. 57)

A obra artística ao ser apresentada ao público, encontra-se em um diálogo de trocas e compartilhamentos afetivos. Ela se desmembra, se desdobra e se desempacota diante dos diversos olhos e faros que a rodeia, vira obra líquida, aberta para respostas, sugestões e interferências permeando as relações humanas com seu meio. Eco (2007, p. 46) nos traz o conceito de Obra Aberta: "Com essa poética da sugestão, a obra se coloca intencionalmente aberta à livre reação do fruidor. A obra que 'sugere' realiza-se de cada vez carregando-se das contribuições emotivas e imaginativas do intérprete". O trabalho artístico é organizado pelo seu fazer poético e presenciado pelas diversas leituras poéticas. Ainda com Eco (2005, p. 49) a obra de arte pelo conceito de Obra Aberta não necessariamente precisa ser indefinida e emotiva, ela pode passar pela dureza da rocha e atingir o meio da testa azul de alguém, para assim ser tratada pelo Pato.

Tanto o material estético produzido pelos artistas, quanto o próprio artista e o público passam por um processo criativo pessoal, um convite para se sujarem do material de vida do outro, como Bourriaud (2006, p. 80-81) assinala: "Pois a arte não transcende as preocupações do cotidiano: ela nos põe diante da realidade através de uma relação singular com o mundo, através de uma ficção". É na ficção criada pelo artista e na fricção do trabalho artístico com o público por via dos sentidos, das experiências, das expectativas, que este público se faz público e se liga em uma relação inter-humana que reverbera além das inquietações do artista. Temos então, uma arte relacional, das aproximações corporais, das interações e dos contextos sociais.

Por mais que algumas práticas artísticas não estejam dentro dos aparatos simbólicos da linguagem conhecida, o trabalho artístico auxilia o ser humano a produzir um ato de expressão e nomeação simbólica por via da experiência de vida, com Medeiros (2005, p. 43) temos que "[...] o objeto estético nos separa do mundo para criar um mundo que lhe é próprio: Um mundo entre o sujeito e a obra." São remotas as possibilidades do ser humano de ao se relacionar sair ileso. A tinta que sai da tela, a rua que é um palco a céu aberto, o cuspe do ator e da atriz que entram em minhas orelhas, o movimento que me embala para presente e se não fosse pelo violão eu recolheria as minhas cordas. 


\subsubsection{ONDE A EXPERIÊNCIA TOCA}

O processo criativo apresentado neste trabalho foi ocasionado pelo encontro da artistapesquisadora em ambiente hospitalar de tratamento psiquiátrico. Devido ao contato próximo a este contexto ${ }^{48}$, pôde-se perceber ligações entre meu corpo, enquanto um corpo de vivências, meu fazer artístico, e o quanto que esta prática se mostra enlatada, e minhas opções de experienciar a vida. Em nenhum momento se ansiou um estudo de laboratório artístico, realizado muitas vezes por atores, para a representação de um ser humano tido como "louco" 49. Ao estar em um hospital pede-se por atenção, carinho, sensibilidade, abertura ao outro e compartilhamentos.

A experiência é o que nos passa, o que nos acontece, o que nos toca. Não o que se passa, não o que acontece, ou o que toca. A cada dia se passam muitas coisas, porém, ao mesmo tempo, quase nada nos acontece. Dir-se-ia que tudo o que se passa está organizado para que nada nos aconteça. (LAROSSA, 2002, p. 21)

As experiências obtidas foram agregadas, como carro alegórico, em meu corpo ao longo de três anos, com visitações semanais onde passava duas horas dentro do ambiente de tratamento psiquiátrico e depois voltava para minha casa e para minha família. Aos meus olhos, adentrar em um hospital psiquiátrico é ir de encontro a pessoas que tentam se expressar por um corpo que sofre pela contenção medicamentosa, social, farmacêutica, pessoal, psicológica... A ida a um hospital psiquiátrico não é apenas um se dar ao outro, mas também um ir de encontro a mim. São diversas experiências que se vive neste espaço, como um momento de uma paquera descarada, um cuspe que desce pelo pescoço, uma fala embolada de língua enriquecida, um falar alto, um pedir por um abraço, uma cantoria, as músicas bregas que relembram suas/minhas afetividades, um fazer anéis coloridos com saco plástico, um querer algo que não se sabe, um puxar com força e um tentar mostrar sua singularidade dentro de um processo de "reestruturação" em hospital psiquiátrico. O de fora é como boia no mar de gente. O de fora sempre será o de fora. Em um trabalho assim, o de fora só estará dentro, de um sistema... A criatividade, o afeto, o subjetivo não está na bula do remédico. O indivíduo é dual. O hospital não passa, entala e quem me toca são mãos sem luvas.

\footnotetext{
${ }^{48}$ Instituições psiquiátricas, médicos, enfermeiros, assistentes sociais, terapeutas ocupacionais, psicólogos, arteterapeutas, serviços gerais, administradores de instituições psiquiátricas, burocracia, agentes transformadores, remédicos, familiares, minha memória afetiva, meio social.

${ }^{49}$ Não desdenho dos processos criativos que realizem laboratórios artísticos, respeito as diversas opções de se expressar, sabendo que existe espaço para todos colocarem em prática seus projetos da maneira que for melhor.
} 
Pedir licença a essas pessoas e a toda uma história histérica construída a cerca da loucura, me permite aprender e apreender a cerca de mim e do que quero com meu trabalho. Foi de dentro do Hospital, mas especificamente no HUP, que aprendi a utilização do "Por que não?" na arte. Olhar as manifestações artísticas de corpos singulares e expressivos com respeito afetivo e notar em algumas estéticas artísticas que se mostram, aos meus olhos, fechadas, enclausuradas, institucionais, instinto.cio.nais, o “Por que não?”. Não é que deva ser de outra maneira, mas o formato que conheci não me basta neste corpo de hoje, na linha anterior e quem sabe não valerá no ponto final desta dissertação.

Sou a favor da arte Kool, arte 7-UP, arte Pepsi, arte Sunshine, arte 39 centavos, arte 15 centavos, arte Vatronol, arte descongestionante, arte plástico, arte mentol, arte L\&M, arte laxante, arte grampo, arte Heaven Hill, arte farmácia, arte sana-med, arte Rx, arte 9,99, arte agora, arte nova, arte como, arte queima de estoque, arte última chance, apenas arte, arte diamante, arte do amanhã, arte Franks, arte Ducks, arte hamburgão. (OLDENBURG, 2006, p.68)

Prefiro a arte de boteco, de almoço em família no domingo, arte perdida, arte MPBrega, arte colorida anos 80, arte multidão, arte efêmera enferma. Escrever a respeito de uma prática processual de relações adoecidas e suas disponibilidades, quando se tem, me fortalece ao relatar minha prática a partir das minhas experiências, não só no hospital, mas também no contexto pessoal. Logo, ressalto que apesar do riso amarelo deste trabalho acadêmico, isto ainda é algo que possui a sua seriedade. Não é por conter elementos de minha vida com o que é dito brega, nonsense, glitterinado, kitsch que este trabalho perde o seu valor ou seu teor, "Somos - você, qualquer um, eu - responsáveis por nossas palavras e atos e reconhecidos como seres responsáveis, logo, temos o direito de designar um objeto como arte, e aquilo que assim designarmos será arte para nós, e isso será indiscutível". (MEDEIROS, 2005, p. 35). O que está nomeado, nomeado está, apesar das relações de poder e legitimação.

\subsection{APRESENTAÇÃO: 1AZÚLi}

Dos meus 13 anos aos 16 anos tive a minha primeira depressão e dos meus 20 anos aos 22 anos tive a segunda. Durante a minha adolescência ainda não conhecia o termo e não sabia da sua profundidade, só ouvia falar e visualizava em seu nome espaços com grandes buracos. lAZÚLi foi o meu encontro com o meu maior buraco. Minha adolescência. "O bárbaro não está mais às nossas portas, ultrapassou nossos muros, está em cada um de nós. Portanto de 
nada serve julgá-lo, ou mesmo, negá-lo. Sua força é tamanha que ele seria capaz de tudo submergir”. (MAFEZOLLI, 1998, p. 9). Meu corpo, enquanto propriedade privada, é terra invadida pelo pensar no pesar da tua língua que recai como gilete em minha pele e enforca o meu riso frouxo.

Morava em uma casa, eu e minha mãe. Morava em uma casa no meio do nada, eu e minha mãe. Morava em uma casa no meio do nada com a rua de barro e terrenos baldios, eu e minha mãe. Morava em uma casa no meio do nada com a rua de barro e terrenos baldios de iluminação falha e assaltos constantes, eu e minha mãe. Às vezes tínhamos um cachorro, às vezes ele morria, às vezes aparecia cobra e todas às vezes minha mãe matava. Quase nunca tínhamos visitas, especialmente nos dias em que chovia, porque na lama só o Corpo Porco é ChicQueiro e sabe brincar. A rua, para mim, sempre era a ida à escola e a volta para minha casa, para meu quarto, para as janelas fechadas, para minha companhia sonora e para aquele corredor em que Artaud vagava.

Eu podia não ter muitas coisas, mas eu tinha papel e caneta, as letras de música que criei, as tentativas de escrever um livro, sonho de ir embora, porque apesar de não conhecer muito além do que minha vista alcançava eu ainda assim sabia que a estrada era o meu lugar. A minha cama foi o meu peso morto. Hoje em dia temos relações bem distintas. Ela encostada na parede e eu onde eu quiser. Minha primeira depressão foi a de me achar estranha no mundo. De querer ser o que diziam que eu não podia ser: livre.

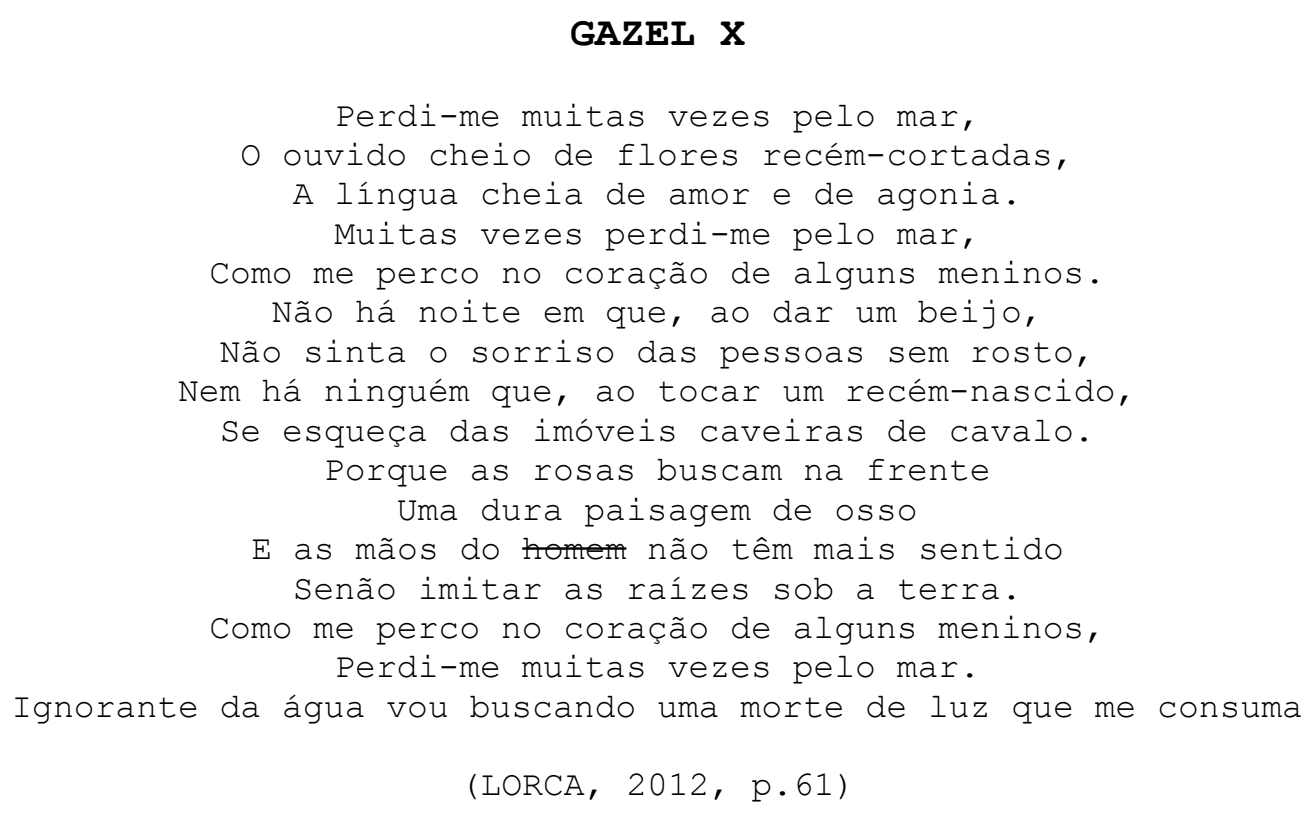

Eu estava em formação de mundo recebendo as minhas primeiras experiências, eu sentia 
como se meu pulmão fosse um fogão a gás e minha cabeça estaria respirando para dentro. Ficar sozinha quando se queria multidão me des.loca.va. Das amizades que fiz, nesta época, me recordo de uma menina de cabelos de fogo que tomava remédicos psiquiátricos porque se cortava muito e arrancava seus cabelos com a mão e um menino que uma vez me falou que, às vezes, se cortava e fazia cortes em formato de cruz em seu braço. Eu pensava que essa dor no limbo era só minha. Uma vez me cortei, antes de agir liguei para alguns amigos para que pudessem conversar comigo até essa vontade passar, eles estavam todos reunidos no colégio, dançando alguma coisa da época... Eu não podia ir porque não haveria quem me deixasse em casa no fim da noite. Eu fiquei azul a ver navios.

No mais, quando andava com a sombra da lua a pino piro, voltando para casa, com a boca cheia de raiva, eu pedia para o vento levar meu pedido aos ouvidos perdidos da noite. Meu desejo, naquela época, era ser estuprada e em minhas orações, deitada em minha cama, pedia para aquele que é tido como o supremo que me matasse, porque eu não conseguia fazer e preferia que outro fizesse por mim. "A doença é a zona noturna da vida, uma cidadania mais onerosa. Todos que nascem tem dupla cidadania, no reino dos sãos e no reino dos doentes!" (SONTAG, 2007, p.11). Depois disso, o sono sempre me embalava em folha de bananeira e me levava para longe. No mais, não mais.

Nunca $^{50}$ tomei remédico para tratamento psiquiátrico, nem falei para os meus pais o que se passava dentro de mim. Não foi por falta de atenção deles, mas eu sentia que eu tinha pulado de um barco: ou eu aprendia a nadar sozinha ou eu me afogava. Aquilo era algo meu comigo. lAZÚLi me recorda as pedras no meu sapato. Meu corpo, em relação com a minha prática artística, precisava falar a respeito do que me calava e eu consentia. "Quando nós nos enlouquecemos por dentro e temos que comunicar aquilo que está dentro da gente e não sabemos o que é para poder organizar novamente nosso mundo nós produzimos coisas a partir desta desordem interior." (HADDAD, 2014) ${ }^{51}$. Foi estruturando as dores, reunindo referencias visuais, pesquisando maneiras de realização e materiais a serem utilizados que aos poucos o sentimento adoecido adormecido desaguou pela face.

De hecho, siempre resulta doloroso exhibir y documentar nuestros imperfectos cuerpos, intervenidos por la cirugía mediática, cubiertos de implicaciones políticas y culturales. No tenemos otra opción. Es casi un "mandato" a falta de un mejor término. (PEÑA, 2005, p.205) ${ }^{52}$

\footnotetext{
$\overline{{ }^{50} \text { Cada corpo com suas regras. }}$

${ }^{51}$ Palestra de Amir Haddad em anexo a esta dissertação.

${ }^{52}$ As citações em espanhol não serão traduzidas.
} 
lAZÚLi vem da referência à Lápis Lazúli, uma pedra natural, de cor azul, nas variações de $\mathrm{IKB}^{53}$, utilizada para o alinhamento do chakra laríngeo e também utilizada, nos séculos XVII e XVIII, para tratamento da melancolia (FURTADO, 1995). lAZÚLi, enquanto performance, foi realizada no ano de 2013, sendo trabalhada enquanto um divisor de águas em minha vida. A apresentação aconteceu em um sítio na cidade de Aldeia/PE, juntamente a outras performances ritualísticas. Penã (2005, p.204) afirma que o "Nuestro cuerpo también es el centro absoluto de nuestro universo simbólico". Enquanto artista eu precisava me posicionar além das palavras, não só pelo tipo de trabalho que desenvolvo em ambiente hospitalar mas também por mim e pelas minhas experiências.

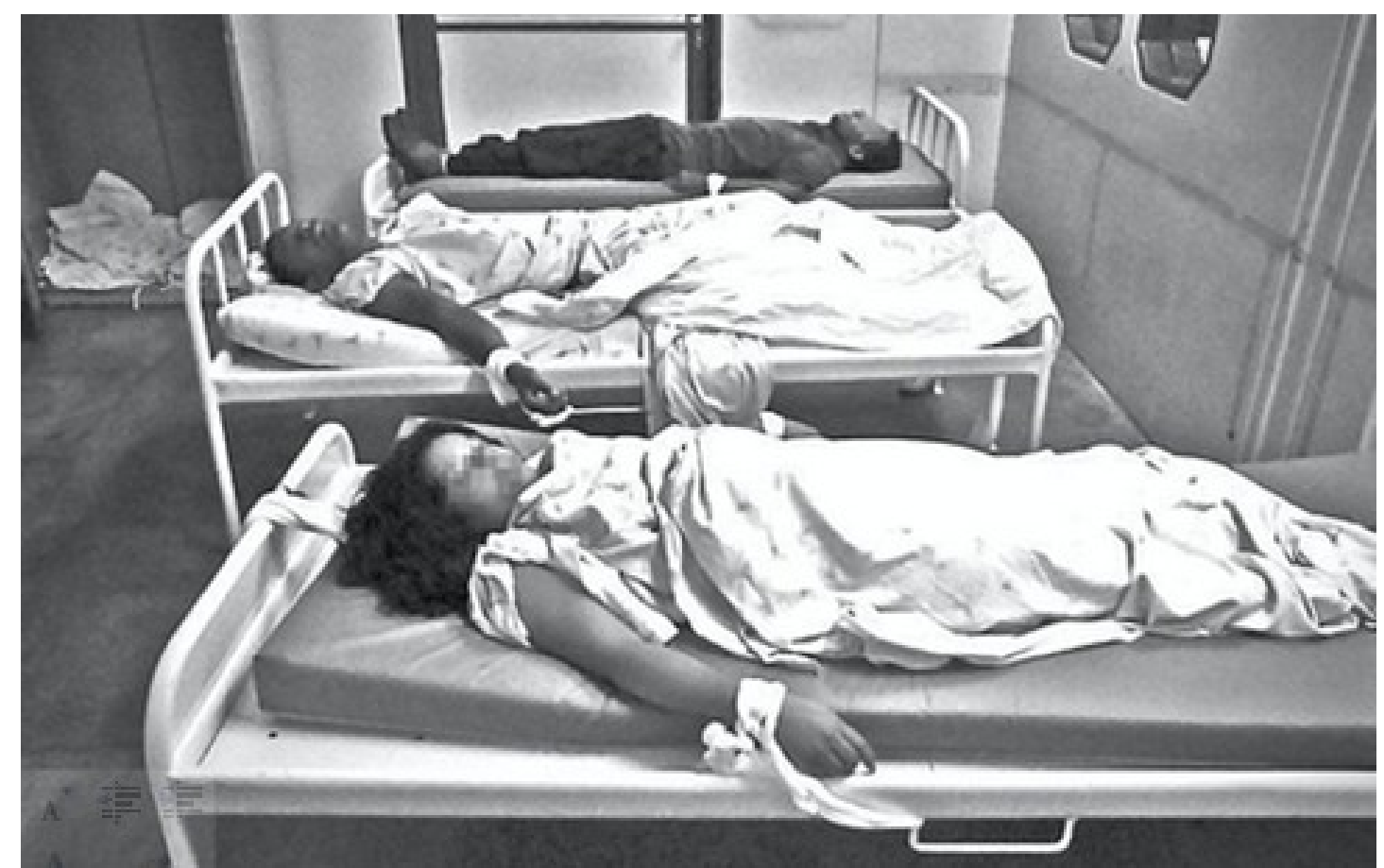

Fig. 03 - Pacientes em Hospital Psiquiátrico

Quando esta ação surgiu, eu já realizava o projeto Doida de Pedra no ambiente da saúde mental. Durante a pesquisa para reunir elementos e conceitos que integrassem esta ação, senti a necessidade de falar do meu corpo doente e percebi uma relação direta com o ambiente do hospital psiquiátrico. lAZÚLi ganhou forma após ler uma matéria de jornal online, que contava com acusações de maus tratos em hospitais psiquiátricos aos seus pacientes. A notícia trazia algumas imagens, porém uma chamou minha atenção, a Fig. 03 que mostra três camas com três pacientes amarrados e sedados. Essa imagem reverberou violentamente em

\footnotetext{
${ }^{53}$ Yves Klein Blue.
} 
meu passado me mostrando o quanto dopada já estive e como eu já havia me prendido ${ }^{54}$ às amarras imaginárias do social, sem contar que este método é de uma violência inefável ao ser humano.

O meio social é violento com aqueles que não condiz com a sua lógica. Qua, qua. Com a criação de espaço para tratamento psiquiátrico as minorias que não eram vistas como pertencente socialmente foram catalogadas e excluídas do ar livre para um depósito de gente, podendo ser eles: moradores de rua, mulheres ativas socialmente, ciganos, artistas de rua, médiuns, negros, crianças, magos ${ }^{55}$ e por fim os que supostamente diziam ter algum transtorno mental. Na tentativa falha de calar um corpo que pulsa, interferências em seus corpos, não mais seus, porém da ciência/Estado, foram realizadas, como: estímulos com odores fétidos, ingestão de ferro, sabão, café amargo, ferimentos causados no corpo do paciente (FURTADO, 1995) a fim de que a loucura (de ser o que se é) saísse e outros. Hoje em dia ainda se encontra prática de eletrochoque em alguns lugares, abuso de internos por parte da equipe de funcionários dos hospitais, além da indústria farmacológica e suas possibilidades remédicas sendo usadas como brinquedo na mão de alguns/algumas médicos/médicas imprudentes e seres humanos ${ }^{56}$ que podem não se adequar à medicação. Esses remédicos, como são utilizados por longo tempo, dão alguns efeitos colaterais que podem vir a pedir por outros remédicos e assim sucessivamente. Instinto.cio.nal.

Minha cama, aquilo que deitava em mim, objeto simbólico, pessoal e sintomático foi objeto fundamental para realizar a ação. Testamos as amarrações, o corpo colchão com queda amortecida pelo piso, o lençol, que me encobria, cortado em quatro. Em apresentação, meu corpo era nu azul. A nudez poderia ter sido substituída por algum elemento representativo como camisola, cobertores e outros. Para lAZÚLi (Fig. 04 e Fig. 05), meu corpo amarrado nu, aberto às provas do tempo, submisso aos desejos de adolescente, despertava o meu eu bicho, a coisa, coisinha, menininha, azul em meu corpo, minha cor em Krishna. Eu como deusa e parte integrante dos cosmos.

\footnotetext{
${ }^{54}$ Ainda estou presa.

${ }^{55}$ Dentro de um espaço de enclausuramento e de experimentações médicas, estas pessoas, todas com uma demanda diferente, não tinham como não adoecer no que era apontado como loucura.

${ }^{56}$ Não só o paciente psiquiátrico, mas também os que sentem qualquer desconforto com o corpo em vias de doença ou social.
} 


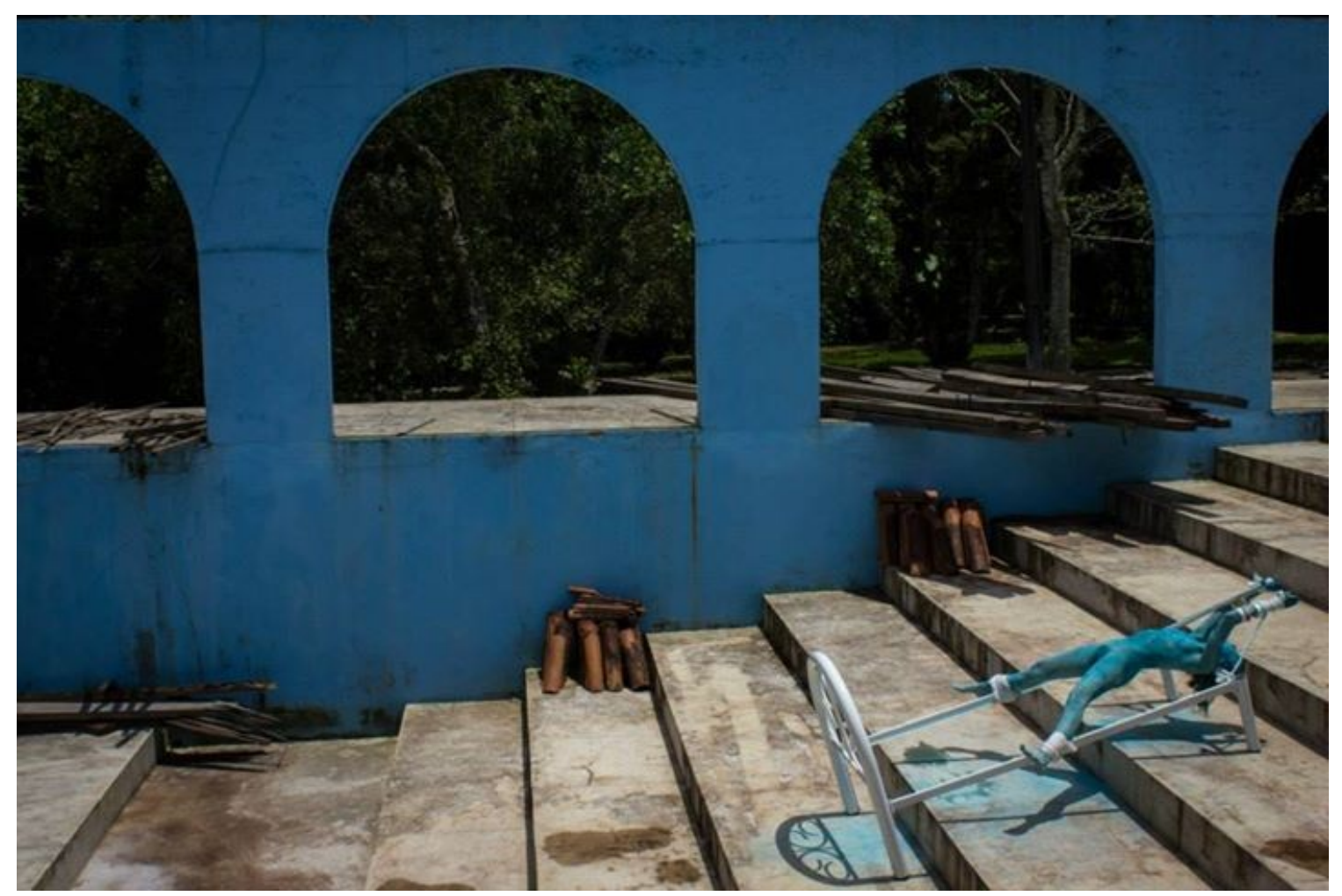

Fig. 04 - Apresentação $l A Z U ́ L i$.

Com os braços e pernas amarradas dentro de um vazio cama/maca respeitei o tempo do sol e do meu corpo. Aquela, que antes se encolhia no meio fio do colchão, foi surgindo das catacumbas do inferno ou no canto dos anjos, a vontade de me soltar, a água querendo rolar e meu corpo coisa em ringue com a cama. Aos poucos, minhas pernas foram se desamarrando, me possibilitando ficar de pé. Trouxe a cama comigo em um trajeto que durou $1 \mathrm{~h}$. Se era vingança por nossa vida a dois, não sei. A cama pelo caminho foi se desmontando, foi perdendo suas partes e eu, tão parte integrante dela como ela de mim, a coloquei no colo, nas costas, nos braços, no lombo para que juntas pudéssemos terminar o que começamos e assim nos despejar no rio. Wanderley (2002, p. 16) nos mostra que "Embora o sofrimento não determine a arte, a preocupação acerca do real e do imaginário, da fragmentação e da unidade, a experimentação de novo código de comunicação com o mundo aproximam as duas experiências". A cama passa bem e continua no mesmo lugar de sempre.

Mondrian, se sua força pode me servir, seria como um bife cru colocado neste olho sofrido para que ele veja mais depressa possível e possa encarar esta realidade às vezes tão insuportável - o artista é um solitário. Não importam os filhos, amor, pois dentro dele ele vive só. Ele nasce dentro dele, parto difícil a cada minuto, só irremediavelmente só. [...] Hoje eu choro - o choro me cobre, me segue, me conforta e acalenta, de um certo modo, esta superfície dura, inflexível e fria da fidelidade a uma idéia. (CLARK, 2006 apud MILLET, 1992, p. 48-49)

$l A Z U ́ L i$ é filha única, não faz diferença no mundo, mas precisou ver a luz do dia. Não teve anúncio para sua divulgação e nem público aberto. Realizada em um sítio no meio urbano a 
apresentação foi acompanhada por moradores da redondeza, companheiros artistas que às vezes passavam e pela fotógrafa ${ }^{57}$, que esteve a todo momento junto comigo na apresentação. As fotos, que não falam do meu suor, andam mais do que minha presença. Milliet (1992, p. 26) afirma que "... a obra de arte em sua capacidade de transcender a própria materialidade, criando significações, renovando-se continuamente num fluxo que integra o artista, obra e fruidor". O frui.dor se agrega em meu corpo afetivo e se camufla. Aquilo que penso em colocar como prática, para minha percepção está claro, o trabalho em seu momento de execução, por mais fechado e esquematizado que seja, fala por si, possui sua auto-expressão, meu corpo integra esse fazer. $\mathrm{O}$ artista e sua arte é uma dupla sertaneja e quando o frui.dor entra viramos um trio elétrico.

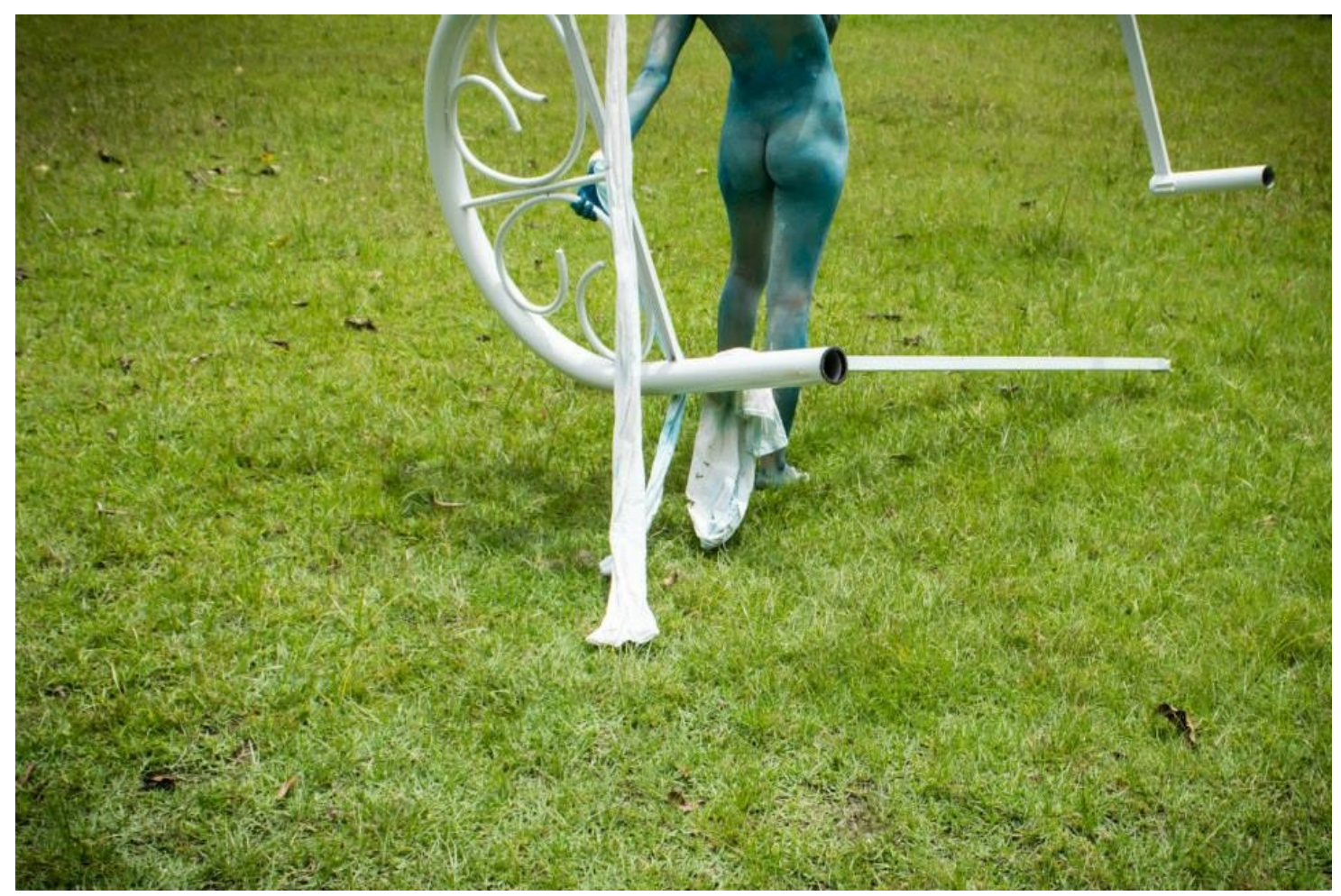

Fig. 05 - Apresentação $l A Z U ́ L i$.

Há um mundo abaixo do abismo, no fundo do mar, existe vida dentro do mangue, na boca escovada, dentro de um formigueiro. Ter a arte como companheira expressiva de múltiplas possibilidades permite ao corpo nosso de cada dia explorar outros contornos e sensibilidades. Para quê serve a arte? Para quê serve o teatro? Para quê serve uma intervenção artística ou uma performance? Para quê gastar energia e recursos próprios para realizar algo que poucos verão? Outros inferno, vão virar a cara dizendo ser uma prática de desocupado, que isso não é arte e coisas afins. "É preciso encontrar o outro, mas é fundamental o retorno à solidão. É preciso chegar e ir-se, alcançar e recolher. Viver para morrer.” (SAFRA, 2004, p. 25). Nós,

\footnotetext{
${ }^{57}$ Beth Moreira.
} 
como artistas, ruminaremos até deixar para fora o que não pertence apenas ao nosso corpo. Em arte nosso primeiro passo é em solo. A arte sai porque não cabe mais dentro. 
 \\ CARTA PARA ARTAUD}

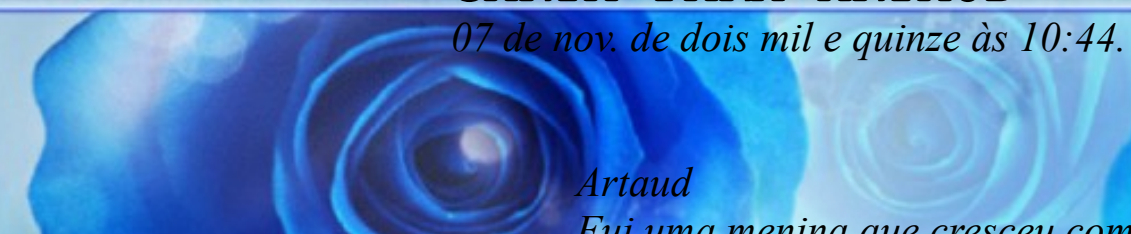

Fui uma menina que cresceu com olhares que me atravessa

- respondi

Passava

E não passou

Na primeira $i$

Você pode,

Depois...

Não.

O amor me foi vendido por quilo, quando abri, era sardinha com molho de tomate "Lá fora é perigoso"

"Carnaval já passou"

"Você é muito histérica"

"Lá vem a árvore de natal"

"Você parece uma criança"

"Não saio com você vestida assim"

The Clash From Hell to Eternity.

Aquele souvenir de plástico da loja de R\$1,99 durava mais do que meu sorriso.

O estranho

O bizarro

O brega

O corpo

O grotesco

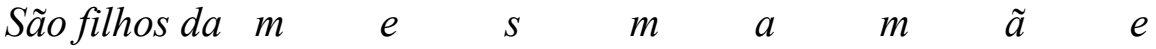

A sociedade

A loucura

A história

A família

A medicação

Artaud, nós somos malvados, tenho lua em aquário e o que não está em acordo é como um tiro na multidão.

Correm para a margem $e$ a bala fica

só, no

meio 


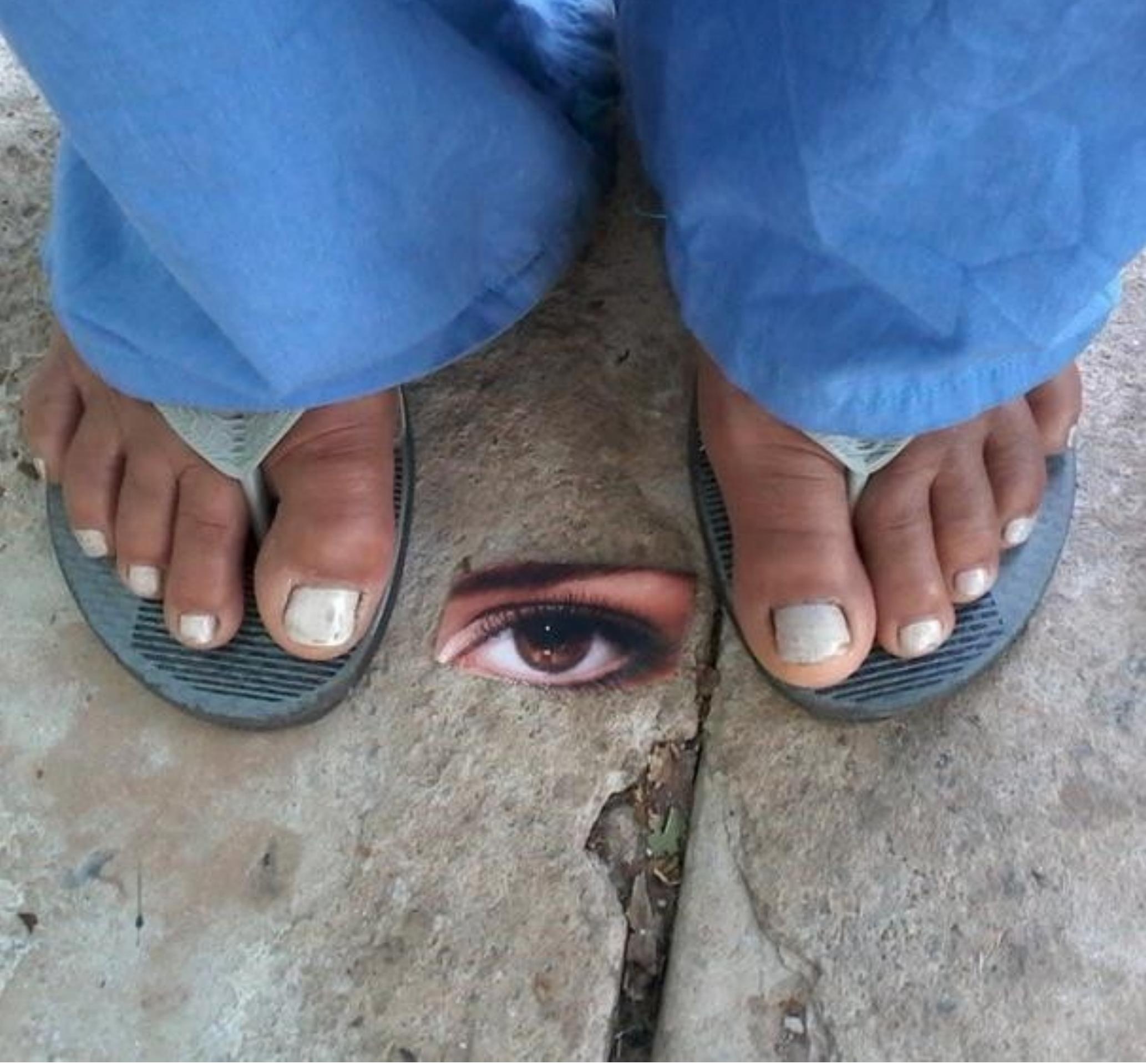




\title{
2. PATOLÓGICO: A LÓGICA DO PATO ou BAILA TU CUERPO ALEGRIA MACARENA
}

\author{
O PATO \\ Lá vem o pato com a pata aqui com a pata acolá \\ Quién? Quién? \\ Lá vem o pato para ver o que é que há \\ o pato pateta olhou o caneco \\ Chamou a galinha \\ Diagnosticou o marreco \\ Dono do poleiro \\ Tava com o pé saudável \\ Falou da rinite \\ E saiu entalado \\ Comeu dez caixas \\ de remédio pra asma \\ ficou engasgado \\ e foi internado \\ com o pé inchado \\ quebrou a enfermaria \\ Tantas fez o moço \\ Que foi pra coxia \\ (Composição: João Gilberto e Authora Desconhecida ${ }^{58}$ )
}

$\mathrm{O}$ Pato $^{59}$ não ama o que está além de sua poça. Apesar de estar $f a(r)$ dado ao mesmo fím de todos os Patos, Ele não se deixa abalar e $m a(n)$ tem o ritmo para não perder o marca-passo. $\mathrm{O}$ Pato, de penugem alva como os primeiros raios de sol, cintila suas armas intergalácticas de poder incontestável em busca da salvação do mundo. O deus perdido em cada um de nós existe no Pato, que com os seus conhecimentos culinários guarda para aqueles que suplicam por seu amor, uma deliciosa receita preparada com muito $\mathrm{mg} / \mathrm{ml}$. Sontag $(2007,65)$ afirma "A doença, que poderia ser considerada uma parte da natureza, assim como a saúde, tornou-se sinônimo de tudo que era 'antinatural'". O corpo não pode cair, nem ao menos em si, que logo é levantado por um amor que estabiliza, cessa, desce bem, te acalenta para o sono, te acalma e te alivia onde dói. A dor azul é ardor em pernas inquietas e risos em fotografias.

A Lógica do Pato $^{60}$ é auxiliar os que precisam. Às vezes seu coração maternal aprisiona os que Ele ama com a sua super dosagem patológica do dia. Nós os patetas, não entendemos do

\footnotetext{
${ }^{58} \mathrm{Eu}$.

${ }^{59} \mathrm{O}$ Pato, para este trabalho, tem como figura central o médico, que socialmente, é tido como o detentor do conhecimento sobre o nosso corpo e com isto, muitas vezes, realiza práticas abusivas.

${ }^{60}$ A Lógica do Pato é um conceito para falar do que é patológico.
} 
nosso corpo, não sabemos dos animais que guardamos dentro de nós, mas dançamos a música que é tocada com os passos ensinados, aqueles que se perdem logo são realinhados porque o importante é saber que os patetas estão bem, revigorados, harmoniosos e se divertem, já que rir é o melhor remédico. Peña (2005, p.205) comenta que "Es precisamente en las tensiones del riesgo donde encontramos nuestras posibilidades corpóreas y raison d'être". O que o Pato não sabe, é que existem nos patetas segredos que o Pato não precisa conhecer, pois pode se deparar com a sua imagem refletida. O Pato sabe das linhas impressas em meu corpo, mas não sabe o que significam. $\mathrm{O}$ pateta não adoece só e a dor de sua morte não precisa estar marcada em uma prancheta, porque tem dores que não são especializadas e se o Pato fosse menos Pato poderia alcançar os patetas sem precisar limpar as mãos.

\footnotetext{
O olhar médico não encontra o doente, mas a sua doença, e em seu corpo não lê uma biografia, mas uma patologia na qual a subjetividade do paciente desaparece atrás da objetividade dos sinais sintomáticos que não remetem a um ambiente ou a um modo de viver ou a uma série de hábitos adquiridos, mas remetem a um quadro clínico onde as diferenças individuais que afetam a evolução da doença desaparecem naquela gramática de sintomas, com a qual o médico classifica a entidade mórbida como o botânico classifica as plantas. (GALIMBERT, 1984 apud ROTELLI, 1988, p.3)
}

A doença vira ponta da caneta e o corpo doente um passageiro que deixou de ser olhado nos olhos, mas está tudo sob controle, porque essa não é a especialidade da Lógica do Pato. Sabemos que a rotina do Pato não é fácil, seguir seu caminho romântico, de que pode cuidar de todos, sem distinção, pelo bem da humanidade, não é algo que a maioria estaria disposta a realizar e nem poderia, já que o tratar é dele por direito. Ano de 1892, em meio a uma lei patológica que segundo Breton (2003, p.279) “[...] organizou a profissão e assegurou-lhe o monopólio do direito de tratar". O Pato com os seus instrumentos, consegue perceber por via de seu olhar $c(l)$ ínico o problema das vísceras, mas ignoram o seu odor. “[...] os médicos preferem 'atacar as causas exteriores com profilaxia, desinfecção e assim por diante', em vez de voltar-se para as causas verdadeiras e interiores, 'porque é desagradável olhar para dentro de nós mesmos." (SONTAG, 2007, p.44). Por mais que Ele não saiba que cor tem os olhos do furacão, ainda assim Ele sabe o que estes olhos precisam para que melhor vejam sob óculos de bulas burladas

Condições de vida, se tornam simples sinais de uma doença que, ao invés de se inscrever no mundo social, se inscreve no mundo patológico, a doença vem subtraída ao controle do grupo com o qual não pode mais intercambiar, para ser confiada à observação de um olhar, o olhar médico que, autônomo, se move em um círculo onde só pode ser controlado por ele próprio e onde soberanamente distribui sobre o corpo do doente o saber que adquiriu. (GALIMBERTI, 1984, apud. ROTELLI, 1988, p.3). 
Não estive no dia em que foi dado ao Pato a propriedade de meu corpo, o Pato que me olha como objeto de sua pesquisa revisa todos os livros patológicos que já passou por sua mesa de estudos, agora todos empilhados em suas costas, me deixando ver que por trás de sua imagem e semelhança, existe em sua sala apenas uma cadeira para as minhas queixas e uma maca para minha dor. Eu se estivesse bem não procuraria um Pato para passar a manhã, mas sinto que algo não está certo, não está no lugar, que minhas pernas pausaram na caminhada e que algo lá dentro, mais físico do que passional, me curva diante da sabedoria Patológica. Sontag (2007, p.42) coloca que "Bichat usou uma imagem semelhante e chamou a saúde de 'o silêncio dos órgãos' e a doença de 'a sua revolta'. A doença é a vontade que fala por intermédio do corpo, uma linguagem para dramatizar o mental: uma forma de autoexpressão". Quando não estou bem é quando meu corpo está mais vivo, porque ele se manifesta na contramão, aposta corrida e me mostra que sou gente. Meu corpo, que não aguenta uma intervenção mais lenta, não fala enquanto dói, ele se contorce, vira corpo meu de outro, corpo meu doença, doença de um corpo de fora que acopla em mim ou doença de um corpo que nem eu mesma conheço. Doer dói. É doído. Ás vezes não suportamos a dor do corpo, que não pede por um Pato, mas por alguém que cuide da gente com tato e que esse cuidador também seja cuidado.

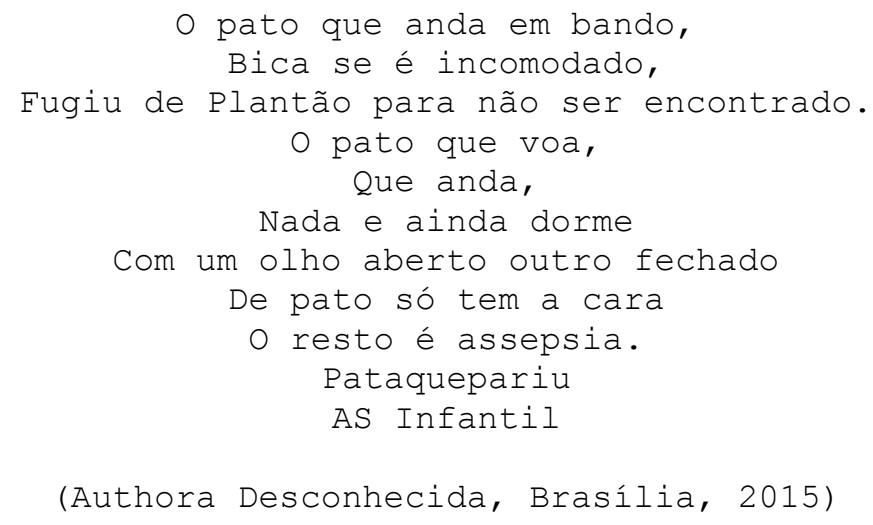

Ás vezes me pego com uma sensação de pensadora contemporânea, perguntando-me se a problemática da Lógica do Pato não seria seus desejos reprimidos. Os Patos me parecem artistas que não conseguiram nota suficiente para estudar artes, apesar de saberem tanto eles têm um texto decorado, uma entonação bem trabalhada, sabem representar seu papel, ser realistas, porém se é para andar, Ele desengonça, se é para cantar, Ele não canta direito, se é para nadar, Ele não faz sincronizado e se é para voar, Ele não vai para lugares desconhecidos. O Pato é um artista fracassado pelo phato de que Ele tudo tem, inclusive recurso, tudo pode, inclusive ser abusivo, sabe ser convincente, mas Ele não toca. Conclusão: Os Patos não 
podem usar anéis.

[...] Apenas nós é que estamos acostumados com que as paredes é que tenham ouvidos, e não os maluquinhos. Por onde, pelo comum, poder-se corrigir o ridículo ou o grotesco, até levá-los ao sublime; seja daí que seu limüe é tão tênue E não será esse um caminho por onde o perfeitíssimo se alcança? Sempre que algo de importante ou grande se faz, houve um silogismo inconcluso, ou, digamos, um pulo do cômico ao excelso. Conflui, portanto , que: Os dedos são anéis ausentes? (ROSA, 2001, p. 39)

Os Patos talvez sejam os que mais sofrem de todos nós. A sua paixão é solitária em seus escritórios, onde tudo passa menos Eles. Compaixão ou sem paixão, o sofrimento escorre pelo chão e desliza em suas canetas pretas de escrita fina e faixa dourada. Os Patos, quando apaixonados, seguram os patetas pela coleira fármaco.lógica. Passionais, os Patos, sempre pedem por sua volta, para saber do pateta domesticado que quando se inquieta, liga, pede por atendimento, suplica por um encaixe, para aquele que pode te devolver a vida saudável. $\mathrm{O}$ Pato só existe devido ao pateta inquieto e o pateta inquieto só existe por ter um corpo potencializado. Freud (2010, p. 331) nos mostra que “O inquietante é aquela espécie de coisa assustadora que remonta ao que é há muito conhecido, ao bastante familiar". O corpo saudável é o corpo normatizado, a dor não é normal, não esta no $\mathrm{CID}^{61}$ como saúde, ela deve ser aniquilada. O que dói é o desconhecido, quando no corpo físico este é tocado, apalpado, apontado, arroxeado, quando a dor vem na existência essa não tem lugar. Uns dizem que é na cabeça, outros no coração, o corpo dissociado diria outra coisa. Como Freud (2010, p. 331) fala "O desconhecido assusta", o inquietante é estar no habitual das ações e achar que só porque os olhos já se acostumaram com uma reta a curva pode parecer perigosa. Assim Rotelli (1988, p.3) expõe "Que tratar signifique ocupar-se aqui e agora”. Assim como a vida, assim como a arte.

\footnotetext{
Eis uma das mais belas versões sobre a feitura do mundo. O demiurgo, conta Platão, teria misturado dois ingredientes que já existiam, o Mesmo e o Outro. Quando a mistura parecia mais ou menos pronta, o Outro escapuliu. Rebelde por natureza, ele fazia com que tudo que era de um jeito virasse de outro. O demiurgo se viu em muita dificuldade para contê-lo, acuá-lo, a fim de conseguir que o mundo tivesse um mínimo de estabilidade. Uns dizem que ele conseguiu, outros acham que essa vitória foi provisória, pois o Outro acabou tomando a revanche e o mundo virou esse Caos que nós conhecemos. (PELBART, 2004, p.2)
}

O Pato, que vive em seu amor narcísico, não se deixa intervir por sua própria patologia. $\mathrm{O}$ olho que tudo sabe veio com defeito, ele só olha para dentro de si, para o que dizem ser. Quando algo foge a percepção de seus livros ele experimenta e assim estabiliza. Vira mestre

\footnotetext{
${ }^{61}$ CID é a sigla de Classificação Internacional de Doenças.
} 
da ciência: de dosagem em dosagem pode ser que venha a acertar o que você precisa. Dependendo do nome você tomba e dorme. O Pato não sabe da paixão do louco, da minha loucura, do que pode vir a ser loucura, nem a própria loucura sabe das suas paixões e das metades das laranjas que ela mesma chupa. O Pato mal sabe que o Outro que ele tenta controlar vai além do corpo estranho que ele me dá. Um corpo Outro para um Patinho Feio.

O Patinho Feio em sua paixão avassaladora se machuca ao amar, o Pato se torna a solução em dez gotas em água. A doença vem de muito antes, vem de um meio social normatizado, histórico, de corpos não expressivos ou enclausurados, de vivências tão destruidoras que nem o mais forte dos corações deixaria de explodir. Pelbart (1989, p. 135) nos fala "Liberar o pensamento carcerário e livrar os loucos dos manicômios". É u.tópico viver a liberdade do nosso próprio corpo, se desamarrar das relações de poder, nos perder no escuro. Ainda com Pelbart (2004, p.3) temos que a pessoa que sofre psiquicamente "Ele é atravessado por devires muito intensos, por sensações fortes demais, ele é afetado por um número muito grande de forças, internas e externas, contra as quais ele não tem proteção". O manicômio das regras sociais que privilegia quem brinca de acordo. Não existe o direito de ir e vir para quem é tido pelo Estado como incapaz. E sozinho ninguém é capaz de ir contra o Estado, porque metem o dedo na sua cara e te acham dentro do CID. Rotelli (1988, p.1) coloca "O mal obscuro da Psiquiatria está em haver constituído instituições sobre a separação de um objeto fíctício - a doença - da existência global, complexa e concreta do paciente e do corpo da sociedade". A roupa que deram para o corpo social muitas vezes não é do meu tamanho e acreditar que um hospital psiquiátrico cai bem é a mesma coisa que acreditar que dá para ser cangaceira usando seda. Ainda não sabemos muito sobre nós, mas penso que o buraco sempre é mais embaixo e eu, em minha arrogância patética, defendo o que não surtiu efeito em meus olhos surtados ${ }^{62}$.

\section{CINCO PATINHOS}

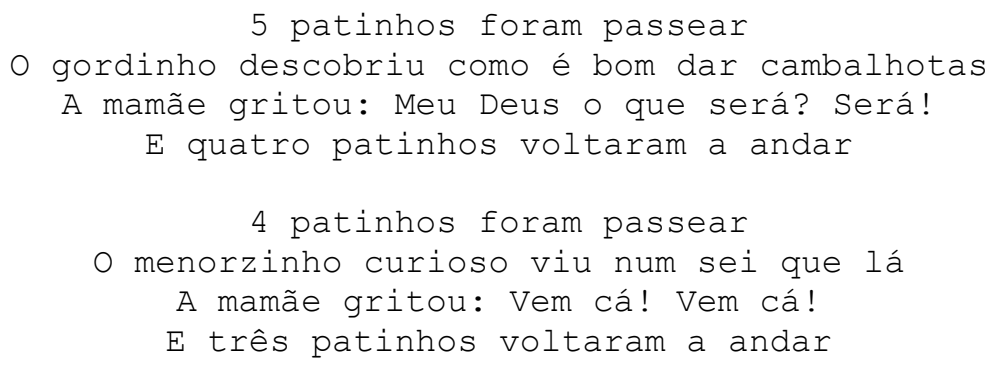

\footnotetext{
${ }^{62}$ Este texto encontra-se generalista. Não sou contra a prática médica, nem o alivio que muitos remédicos podem oferecer aos pacientes (nós, os patetas), mas desconfio que a medicina ainda possui um longo caminho para ser a saída de uma ciência da saúde.
} 


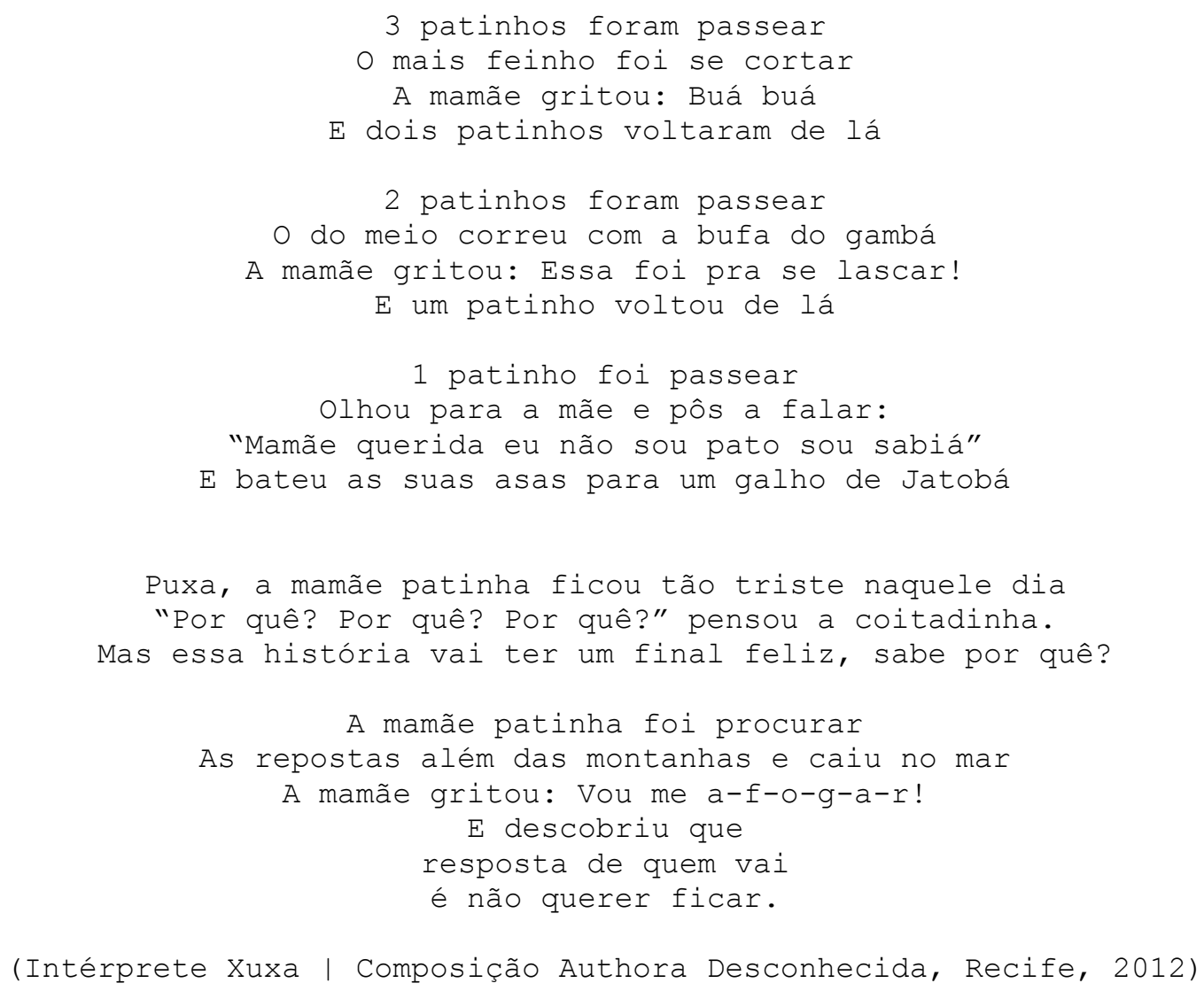

\subsection{BAMBOLEA: A DANÇA CIGANA NO CAPS}

O grupo de dança cigana Ciganos de Luz iniciou no ano de 2003 uma parceria entre arte e espiritualidade, por via do Grupo Esotérico Ramatís - Comunidade o Triângulo e a Cruz na cidade de Olinda/PE. Para o grupo Ramatís a união destas áreas é utilizada enquanto ponto de expansão e ativação de energias. Por via das reuniões mediúnicas de orientação espiritual a respeito da corrente cigana, o grupo Ciganos de Luz adquiriu forma. Foi dado ao ator Adriano Cabral, que integra o Ramatís desde 2000, a coordenação dos Ciganos de Luz, auxiliando no contato do ritmo cigano em apresentações realizadas em asilos, escolas, creches, hospitais, eventos e outros. Em comentário para a artista-pesquisadora o ator explica:

\footnotetext{
Sempre é uma festa de lindos bailados quando o grupo chega aos asilos onde muitas vezes encontramos os idosos cabisbaixos. Tão logo ouvem as músicas alegres e o rodopio das ciganas e os bailados dos ciganos. Eles se enchem de euforia e participam, deixando-se levar pela força e história da dança cigana. (CABRAL, 2014)
}

Por alguns desvios no caminho, o grupo deu uma pausa, retornando suas atividades no ano de 2012, quando Cabral estabelece parceria com a professora de dança cigana Roberta do 
Espírito Santo ${ }^{63}$, iniciando uma associação do grupo Ciganos de Luz (Fig.07) e das aulas de dança cigana e as alunas desta professora.

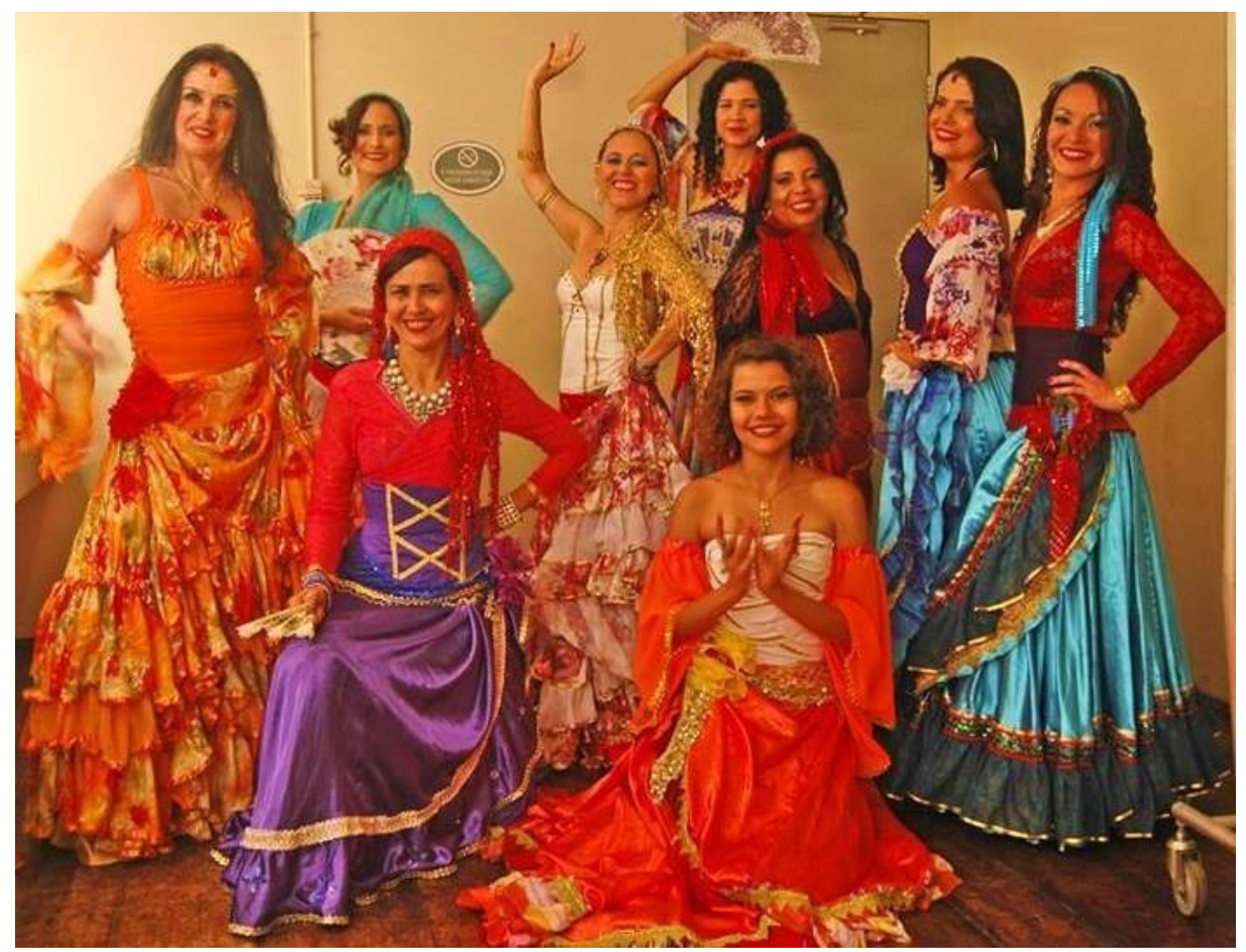

Fig. 07 - Apresentação do grupo Ciganos de Luz no Teatro Santa Isabel - PE

Com esta união, três anos já se passaram e o grupo obteve a possibilidade de expandir suas cores em alguns espaços carentes na cidade de Recife, Olinda e Jaboatão dos Guararapes/PE, bem como em eventos, que exigiam uma maior elaboração das apresentações. Hoje em dia o grupo mantém a coordenação de Cabral, da professora Espírito Santo e é composto por alunas de dança cigana sendo elas artistas, trabalhadoras em áreas diversas e estudantes.

Com o projeto acadêmico no DF e campo de pesquisa teórico/prático na área da arte e da saúde mental, desde maio de 2014 até junho de 2015, aulas ${ }^{64}$ de dança cigana foram ministradas pelo projeto Doida de Pedra ${ }^{65}$, na Região Administrativa de Taguatinga, com a Oficina de Dança Cigana no Centro de Atenção Psicossocial (CAPS) II $^{66}$ e aulas de dança

\footnotetext{
${ }^{63}$ Roberta do Espírito Santo é professora de dança cigana na cidade de Recife/PE e membro do Cid - Conselho Internacional de Dança, órgão ligado a UNESCO.

${ }^{64}$ Aulas semanais com a duração de 1 h30. A princípio turmas apenas de mulheres, depois com alguns homens. Como a maioria das integrantes eram mulheres, aqui a participação das pessoas será tratada no feminino.

${ }^{65}$ Era explicado que a atividade da dança cigana era realizada de forma voluntária e em parceria com o CAPS, pelo projeto Doida de Pedra e pesquisa de mestrado. As alunas não tinham obrigação de participar do grupo Ciganos de Luz DF.

${ }^{66}$ Atendimento oferecido pelo Sistema Único de Saúde (SUS). Os CAPS são locais de tratamento para pessoas de sofrimento psíquico, seu objetivo é de evitar longas internações nos hospitais psiquiátricos e reintegração familiar/social. Atividade no CAPS supervisionada pela terapeuta ocupacional Maiara Ioris.
} 
cigana, com o enfoque mais recreativo, no Hospital São Vicente de Paulo. Em paralelo existiam visitações mensais aos amigos da comunidade cigana Calon ${ }^{67}$ de Sobradinho/DF.

A dança cigana foi escolhida enquanto atividade a ser aplicada no CAPS II $^{68}$ pelo seu movimento expansivo, lúdico e improvisado. Foi pela dança cigana que o meu corpo se revelou dançante, aprendendo a falar de si por via do bailado. Pode soar prepotente, mas partindo de uma experiência pessoal cogitou-se que outras pessoas poderiam ser atingidas pela mesma energia e alegria desta dança (Fig. 08).

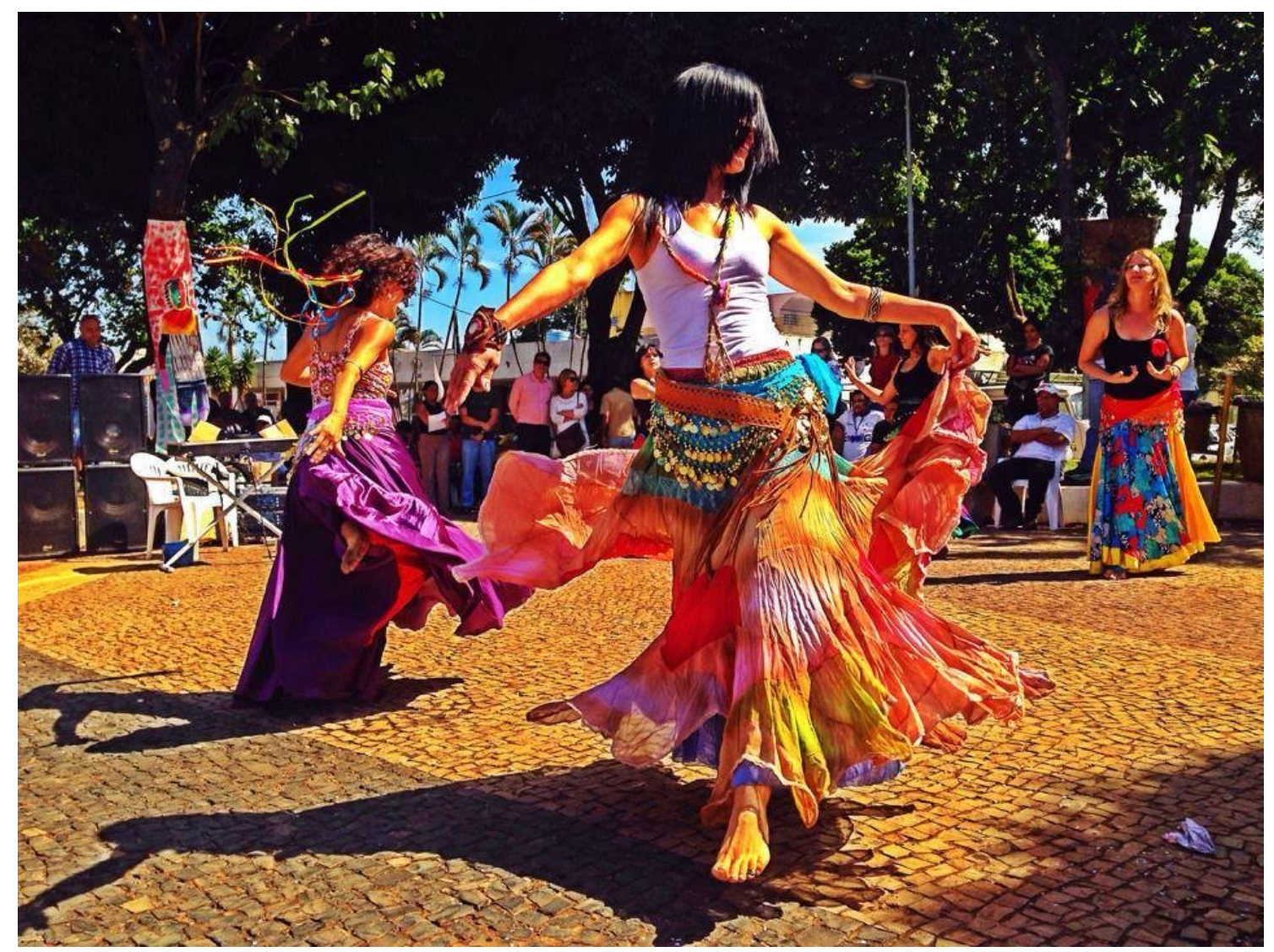

Fig. 08 - Apresentação do grupo Ciganos de Luz na Praça do Relógio - DF

Com as aulas de dança cigana no CAPS II formou-se o grupo Ciganos de Luz DF. Tendo este grupo o mesmo objetivo que o de Recife: levar para outros lugares a dança cigana, compartilhando afetividades. A maior diferença entre os grupos é que os Ciganos de Luz DF tem em sua composição pessoas que passam por um processo de reestruturação emocional intenso, envolvendo idas a psiquiatras e psicólogos, crises, tratamentos não só medicamentosos, mas também pessoal, familiar e social e as alunas não possuíam muitos recursos financeiros.

\footnotetext{
${ }^{67}$ Calon/Kalon ou Kalé é um grupo cigano oriundo de Portugal e Espanha. Os primeiros ciganos Calons deportados chegaram ao Brasil no século XVI. Sua língua é o Chibi Brasileiro, variação do português, romani e caló.

${ }^{68}$ Para este trabalho detalharei a vivência da dança cigana no CAPS.
} 
A dança cigana, em junção com a área da saúde mental, tinha por objetivo, levar suas integrantes a falarem de si de uma maneira que não estão habituadas. No lugar da fala oral o corpo, no lugar da dor a dança ${ }^{69}$ e no lugar dos outros que as circundam, elas mesmas e o coletivo. Vale ressaltar que as aulas eram pensadas a partir da necessidade do grupo, pontuadas pelas alunas, sentidas por mim, observadas pela supervisão e monitoras.

\begin{abstract}
A experiência do prazer se vive de forma familiar, natural, tende a englobar a presença. Ao contrário, a experiência da dor, da fadiga, é sempre vivida a maneira de uma estranheza absoluta, de uma irredutibilidade a si. A dualidade da dor esquarteja a presença, enquanto aquela do prazer a enriquece com uma nova dimensão. Além disso, a experiência da dor ou da doença, devido a sua alteridade, carrega consigo a angustia, a incerteza. (BRETON, 2003, p.146)
\end{abstract}

Nas aulas, algumas barreiras eram quebradas. Com a dança cigana no CAPS II era exposto às alunas que não existia certo nem errado, feio ou bonito para o corpo. Esse se expressa à sua maneira. Quando ele fala revela nossas dificuldades e entraves. Esse corpo experienciado, cheio de conteúdo simbólico adquirido durante os anos de vida, estrala ao se movimentar, para outro despertar. Hilker (2008) em sua pesquisa com ciganos nos mostra que "As sociedades ou grupos, como os ciganos, que têm na tradição oral sua principal fonte de manutenção da memória inscrevem em seus corpos suas memórias, porque o corpo representa lugar e temporalidade". Enquanto bailamos com a dança cigana podemos expor nossos sentimentos, reavivando nossas memórias e permitindo trabalhá-las para um bem estar.

Para alguns clãs ciganos, o ato de dançar não se coloca apenas pelo movimento em si, a dança é uma das maneiras com a qual podem falar do seu povo e sua relação com a natureza. Para esses ciganos, os elementos da natureza os acompanham em suas peregrinações, com o andar pelas estradas, o olhar nas estrelas, as emoções que saem pelos olhos e o fogo da fogueira. Apesar de não existir uma diversidade literária confiável sobre a dança cigana, pode-se notar em pesquisa que, para dançar este gênero, a técnica torna-se secundária. Por ser uma dança que está nos poros se diz que os ciganos dançam com o coração, “A dança? A dança de nosso povo é um grito. Um grito que ecoa no tempo e no espaço. É arte, ritual e diversão. É uma das principais formas de aproximação dos Deuses. [...] O cigano tem dificuldade em exprimir seus pensamentos por palavras.” (KALDERASH, 2005 apud HILKER, 2008, p. 182). O corpo natureza que recolhe parte do trajeto que faz e deposita em seu corpo, no corpo dançado, abre o leque de possibilidades não só culturais como de expressão artística.

Podemos observar que no contato forte dos pés com o chão, encontra-se um meio para

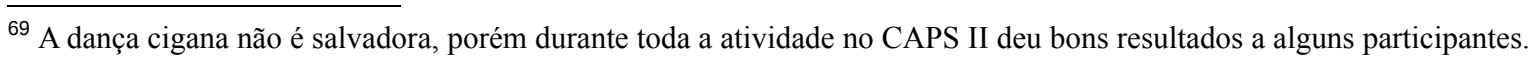


conectar-se com a terra e com ela estabelecer uma forte ligação. A terra aqui compreendida também em seu aspecto metafórico: colocar os pés na terra, pisar o próprio chão: é afirmar o mundo na sua totalidade. (DAMASCENO, 2009, p.102)

Sabendo que a dança está no corpo, as oficinas no CAPS II não possuíam a intenção em transformar as alunas em ciganas, até porque isso seria uma falta de respeito com a cultura cigana mas, a partir dos princípios desta cultura e pela ludicidade da dança, as alunas teriam mais uma ferramenta para transformar seu cotidiano e aliviar suas dores. Assim se coloca a pesquisadora cigana Ramanush (2012) "Quando se fala a respeito da autentica dança cigana não deve ser no sentido da pureza que devemos nos ater. [...] O resultado de toda essa mistura é um estilo único [...] Esse conjunto recebeu ainda a influencia do estilo de vida e tradições de cada grupo cigano".

À princípio as aulas no CAPS II ocorriam em um espaço pequeno, dificultando as movimentações mais expansivas. Em setembro de 2014 as aulas passaram a ser ministradas em um local mais amplo, porém não coberto, o que nos prejudicava quando chovia. Porém, com tal mudança foi possível notar a diferença na qualidade da dança e o quanto ganhamos em expressividade. Para as mulheres era recomendado ${ }^{70}$ construir a primeira saia cigana nas mãos. Este contato mais introspectivo da elaboração e criação de algo que elas usariam em aulas dava não só autonomia, para aquelas que não possuíam condições financeiras em pagar costureira, mas também integrava a aluna consigo e o seu propósito.

A dança surge de uma composição que visa desde a permissão das alunas em se expressarem pelos seus corpos, o ritmo da música com seu estilo, a história da cultura cigana e a magia que existe no imaginário social a respeito dos ciganos. Quando se percebe algum bloqueio nas aulas por racionalizações vinda das alunas como "Eu não sei dançar" ou "Eu não sei fazer isso que você faz", é pedido para que a vontade de dançar, a música e a companhia das demais alunas possa ser um corpo contágio que toque antes a pele do que os pensamentos. A dança cigana para este projeto atua em coletivo, seja na presença dos corpos dançantes, seja com o público no momento da apresentação e com os tantos “eus” que faz morada em mim.

Um dos pontos importantes das aulas são as apresentações em locais como hospitais (Fig. 09), creches, asilos e eventos. Ao realizar apresentações de dança cigana fora do ambiente da

\footnotetext{
${ }^{70}$ As alunas aprenderam a confeccionar suas próprias saias ciganas. Solicitava-se para as alunas que não utilizem blusas curtas, com decotes profundos nos seios ou transparência, saias e forros com dimensões para que as pernas não aparecessem durante o bailado. Respeitando a cultura cigana e os estigmas que está possui.
} 
clínica de tratamento, é percebido, nos corpos das alunas, uma expansividade afetiva sensível e desprendimento das suas realidades. $\mathrm{O}$ reposicionamento afetado das alunas ocorre diante daqueles que as assistem, havendo ali a possibilidade de serem notadas enquanto corpos expressivos em sua alegria e não apenas enquanto pessoas em atendimento no CAPS.

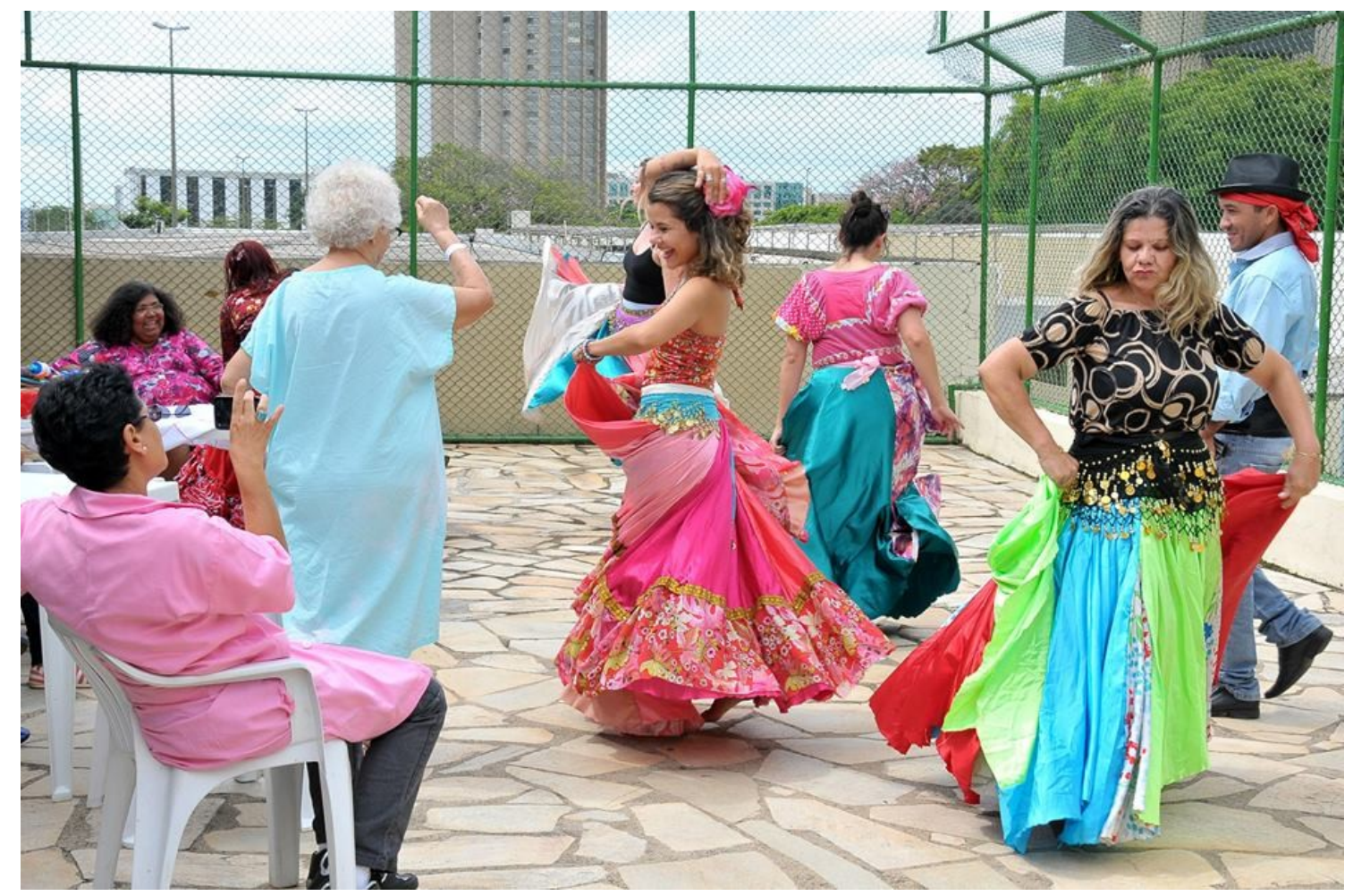

Fig. 09 - Apresentação do grupo Ciganos de Luz DF no Hospital de Base - DF.

O trabalho no CAPS II se apresenta gratificante, receber o retorno da oficina ministrada e os resultados conquistados. Uma das satisfações se dá quando os familiares das alunas se integram a esta dança, ao acompanhar as apresentações. Para este projeto existe a doença, porém antes da doença existe um ser humano. Como explica uma citação atribuída ao médico William Osler que afirma "Não pergunte que doença a pessoa tem, mas que pessoa a doença tem". As alunas das aulas de dança cigana são respeitadas e admiradas pelo momento de vida que estão passando, porém a sua real importância para o projeto, é saber que muito além do tratamento psiquiátrico existe alguém que precisa de cuidado, de atenção, de carinho, de fala e de escuta, e que possa se expressar, seja por via artística ou não. Há necessidade da criação de espaços ampliados em instituições de saúde e de saúde mental para a entrada de artistas, arteeducadores e arteterapeutas. A arte pode auxiliar na condução de energia criativa e mobilizar no tratamento de pacientes e funcionários. Em anexo encontra-se alguns relatos de experiências vivenciadas durante a Oficina de Dança Cigana e tabela de apresentações com o grupo Ciganos de Luz DF. 


\subsection{BAILA TU CUERPO ALEGRIA MACARENA}

No período de 2013 a 2015 durante as atividades realizadas pelo projeto Doida de Pedra era perguntado aos participantes "O que é corpo?”. A listagem a seguir foi construída por pessoas em atendimento psiquiátrico nas oficinas de dança cigana, evento Integração: Arte e Saúde Mental e Amostra Grátis (Fig. 10) nos hospitais psiquiátricos Hospital Ulysses Pernambucano/PE e Hospital São Vicente de Paulo/DF e no Centro de Atenção Psicossocial/DF.

- Espírito, carne, sangue, ossos;

- Segredo fatal;

- Ser humano;

- Virtude;

- Matéria prima;

- Transformação de um espírito;

- Uma inclinação;

- Fortaleza de Deus;

- Instrumento que leva a gente;

- Precisa de cuidado se não cuidar destrói;

- Corpo inteiro - cabeça não faz parte;

- Corpo humano mais corpo que esta vivo;

- Vida;

- É do pescoço para baixo;

- Único ser do patrimônio;

- Único ser que a pessoa tem;

- Acompanhado da alma e do espírito; 
- Imagem de Deus;

- Normal, tem pernas, gravidez;

- Ferramenta de expressão artística;

- Meio de transporte;

- Embalagem;

- Fazer picolé;

- Instrumento que fala porque fala de sentimentos;

- Corpo é se arrumar;

- Força aberta, pensamento;

- Corpo é a parte do corpo todo;

- Membros;

- Inteligência;

- Olhos, nariz, rins, pulmões;

- Corpo é dor, uma flor, alma e coração;

- Corpo é o abuso do homem;

- Corpo louco;

- Corpo é isto (mostra a barriga);

- Corpo é o espírito de Jesus;

- São os membros;

- Você tem esse corpo?;

- Adubo;

- Nossa parte viva;

- Caixa;

- Esqueleto e pele;

- O que nós respiramos;

- Humano; 
- Nossa morada;

- Traição corpo com corpo;

- O corpo é um órgão que a gente se expressa através dele;

- Atitude;

- Interior;

- Simbolismo carne humana;

- Ossos por dentro e fora carne;

- Expressão do que esta sentindo por dentro e o que você vê do outro para interagir em grupo;

- Cabeça, ombro, joelho e pé ${ }^{71}$;

- É esse corpo;

- Mundo, matéria o resto é espírito;

- Disciplina de anatomia;

- Corpo compasso;

- É uma planta que parece que sobe da raiz de pé de maxixe;

- Feito de carne;

- Sistema vascular;

- Funcional;

- Cabeça, tronco e membros;

- Ingrid;

- O que é físico;

- Porco;

- Nossos corpos mortos;

- Todo corpo superado da cabeça;

- É isso aqui (aponta para os seios);

- Base completa para a vida;

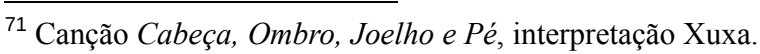


- Desde dos dedos dos pés até afetar a mente;

- Meu corpo meu algo dentro;

- Amor;

- O corpo da gente está em todo lugar;

- Célula formada em outra célula;

- Corpo mente braço mente;

- Roupagem e matéria que libera tudo de bom;

- Formação de ossos depois carne;

- Conjunto de nomes do corpo todo;

- Cabeça principalmente girando no planeta para pensar;

- Eu;

- Que não fica saudável e arrebenta;

- Se não for a gente a gente não vive;

- Sola dos meus pés que manda em tudo;

- Óculos;

- 7 elementos: fogo;

- Espaçamento da vida, direito da constituição;

- É uma coisa que amamos muito;

- Testículos, vagina, cu cabeludo;

- Corpo é uma coisa que deus nos deu;

- É todo seu movimento;

- Extensão da nossa casa;

- Corpo bonito. 


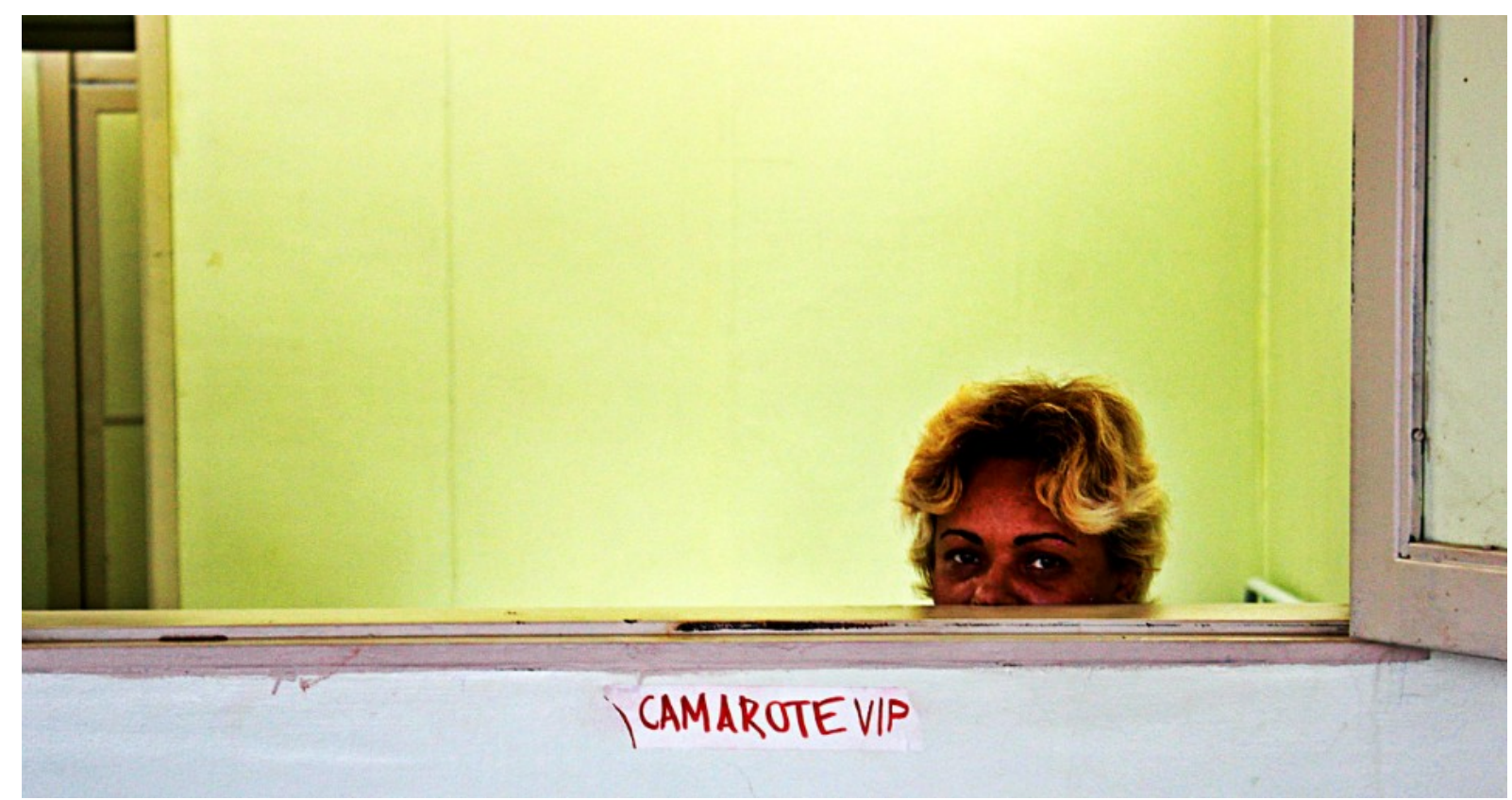

Fig. 10 - Evento Amostra Grátis no HSVP/DF. Intervenção artística de Mariana Brites.

\subsection{O CORPO É UM COPO OCO QUASE CHEIO}

O corpo para este trabalho é visto enquanto ponto de partida para um desdobrar do meu fazer artístico. Este corpo que trafega em mim é o primeiro que chega antes mesmo dos meus passos. É ele que é aceito, negado ou despercebido. Esta pesquisa brotou do corpo, do meu corpo histórico, do corpo do hospital, do corpo da doença, parido nos arrepios, brincadeiras e tonturas. O corpo que se expressa em medicamento social, psiquiátrico e pessoal. O corpo que, mesmo longe das paredes de uma instituição médica, é amarrado nas paredes invisíveis sociais, ainda assim todos somos doentes, sintomáticos, o Pato não precisa levantar sua caneta para confirmar, estamos em uma sociedade adoecida, azul, medicada, instinto.cio.(a)nalizada, que ainda experimenta alguns passos de dança, um grande hospital a céu aberto, uma grande arte que ainda discute o que ela é e o que ela não é. Não existe a cura, existe o buscar estar melhor, existe o se relacionar. O corpo doente, social e artístico são frutos da mesma árvore. Um corpo asfaltado em suas dores por toneladas de caminhões imaginários.

\subsubsection{CORPO PORCO}

Tenho um corpo impaciente, que parece não ter sido feito para as câmeras, que parece não ter sido feito para o teatro, que parece vagar em encruzilhadas puxando carroça, só. Com ideias 
de quem se arranha por dentro e vive nelas. Tenho um corpo que não parece ser o que é, que brilha os olhos com a vontade de um poder vir a ser, mas que nunca sai, nem a cabecinha. Tenho um corpo oco que quando batem ele não abre. Tenho um corpo que quando ri, rasga minha face, mostra meu buraco entre olhos e sente vontade de morder, "A dor faz o corpo explodir..." (SERRES, 2004, p.45). Tenho um coração dividido entre a esperança e a razão, tenho um coração e melhor que não tivera ${ }^{72}$.

O corpo do Pato e dos patetas é múltiplo, com uma infinidade de terminações nervosas, de fluxos sanguíneos, de maçarocas gosmentas, coisas moles, líquidas, cheiro de podre, que bate, bombardeia as cidades vizinhas e que sente pontadas, inchaços, machucados. Um corpo monstro que dói e se dói, não é bom e se não é bom, algo tem que ser feito, mas, dói do nada, e quem nada é peixe. É aí, no meio a uma biodiversidade de dores, que dá para passar com o tempo, que dá para tomar um remedicuzinho, que dá para caminhar com a gente, que faz todo o corpo se desamarrar e vomitar enquanto dança.

Nosso corpo tem imagens e estas imagens agregam sentidos para a nossa subjetividade. Para o paciente psiquiátrico lidar com seu próprio corpo, em relação não só com a matéria física, mas também como a matéria sensível envolve um processo de restruturação de identidade pessoal e social. Quando o coração, balão de ar, instaura no ser humano, a terceira guerra mundial, este perde partes de seu corpo múltiplo. Entrar em contato com certas funções e partes deste corpo pode causar maiores catástrofes. Segundo Pankow (1993, p.23) nosso corpo possui funções da imagem que se estruturam enquanto sentido, ela assim afirma "No delírio crônico não esquizofrênico, a primeira função da imagem do corpo enquanto forma é possível. Mas o doente não é mais capaz de reconhecer as funções próprias das partes do corpo". A pesquisa de Pankow me relembra o comentário de uma participante de oficina ministrada no HUP, que quando perguntada o que é corpo responde:

- O corpo é a parte do corpo todo.

Este o corpo que se integra ao corpo todo, que se separa do corpo todo, que é parido pelo corpo todo e que é partido do corpo todo, é um corpo que em partes sabe da sua existência. Com esta ideia de corpo criou-se artisticamente a fotoperformance Eloucubrações: O Corpo é a Parte do Corpo Todo, como mostra a Fig. 11.

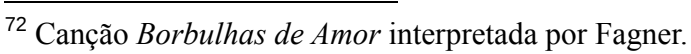




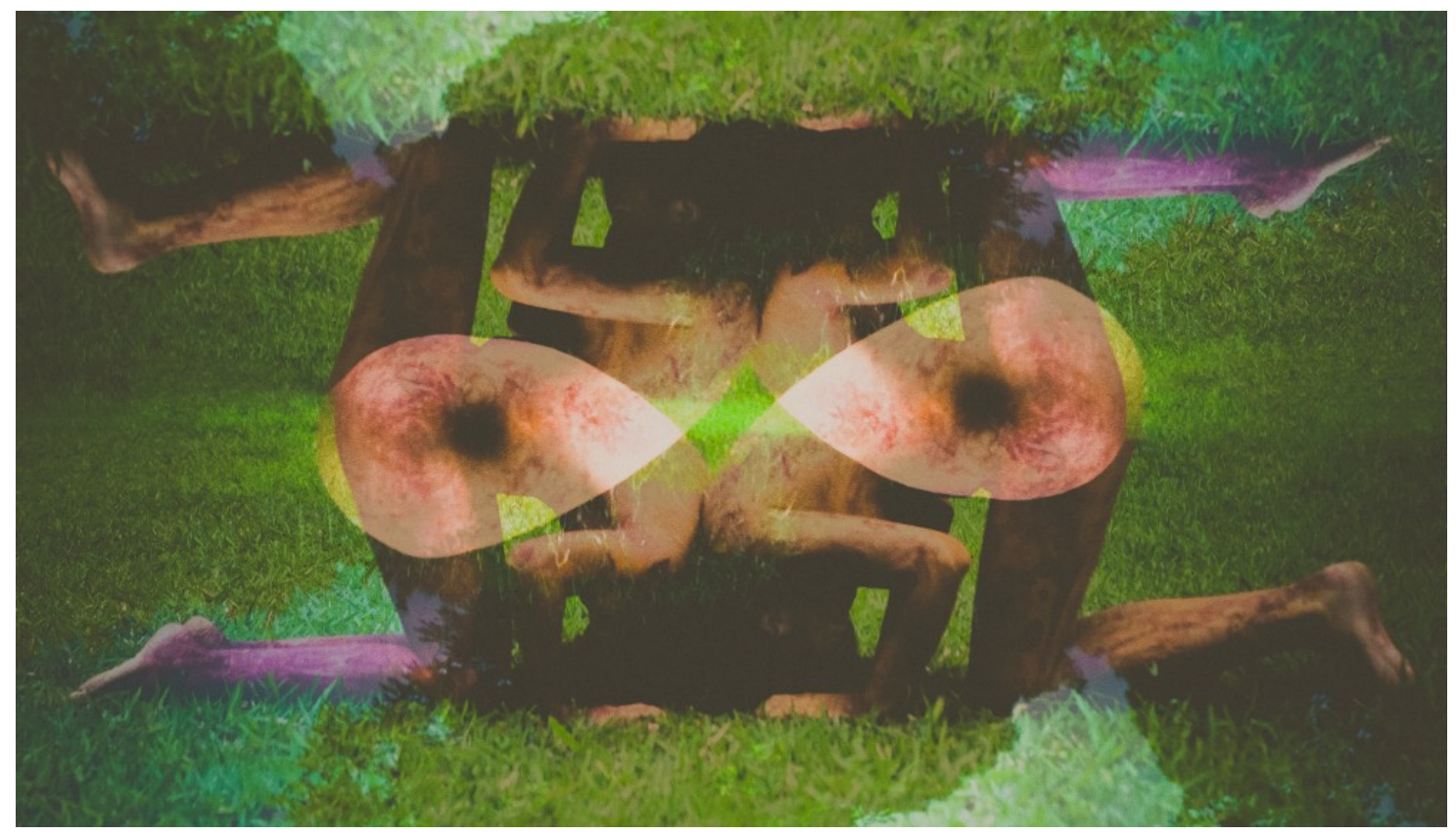

Fig. 11 - Fotoperformance Eloucubrações: O Corpo É A Parte do Corpo Todo/DF.

O ser humano ao ter grande sofrimento psíquico, pode adentrar em níveis de desestabilização corporal, desconhecendo seus contornos e reduzindo a associação da relação deste corpo com outras partes dele, não por maldade consigo, mas como tentativa de estabilizar a avalanche de conteúdo sofredor que toma esse corpo. Ainda com Pankow (1993) temos que este corpo inundado entrega partes de si para não ficar sem sua unidade. A forma se despedaça e, então, se chega ao que é chamado corpo dissociado. Serres (2004, p. 43) explica "O esquecimento alivia o que a consciência torna inflexível". Este corpo dissociado se reposiciona, só que desta vez a parte do corpo é que se torna sua totalidade. Esta seria uma possível experiência corporal, indicada por pesquisadores, que uma pessoa sofredora esquizofrênica pode vivenciar em seu corpo, como uma tentativa de reorganizar, inconscientemente, sua estrutura corporal a partir de seus traumas.

\footnotetext{
Quanto mais o membro se separa, mais ele grita; quanto mais geme, mais se afasta. Ouvi os lamentos do corpo dilacerado. Como meus ouvidos perturbados não podem distinguir entre esse lamento singular e o ruído de fundo que o envolve, o lugar doloroso habita o centro e a totalidade de meu corpo. O sofrimento ocupa agora o espaço. A saúde fazia de mim uma transparência muda, uma ausência, um ponto do mundo sem lugar, um não-eu; a dor o faz inflar até tomar conta de todo o meio ambiente. (SERRES, 2004, 44-45)
}

Acredita-se que a doença só é doença quando a sentimos fisicamente, no corpo material, pois dilaceram nosso corpo e nos dividem em sessões. O corpo vai além do físico e a doença tem a chave da porta para entrar e sair quando sentir vontade. A saúde me faz andar e a doença me 
faz perceber porque estou andando. E ainda assim, possuímos um corpo ou somos possuídos pelo corpo e todo conteúdo simbólico que ainda não está acessível para nós, como forma de autoproteção. Para Serres (2004, p.59) "Na quietude da saúde, o corpo ignora seu pertencimento, a capacidade integral de sua totalidade. Existem apenas descrições das doenças do corpo. Só existem as síndromes, o corpo sadio não diz uma palavra". O corpo quando visivelmente e sensivelmente se quebra, pode ser remontado à maneira da autocura de cada um, com a ajuda de cuidadores que alimentem a ideia de pertencimento deste no mundo, não há mal em adoecer, não há mal em querer ficar melhor, só que em uma sociedade com padrões bem definidos o corpo é apenas um e ele deve ser vivido no valor unitário e a atacado.

\subsubsection{O CORPO É A PARTE DO CORPO TODO}

O corpo nasce brechado pelo olhar clínico ou curandeiro, independente de meio social que este venha a emergir das catacumbas do inferno orienta-se o não əacidental. Este corpo que já vive em formatação Times New Roman, com espaçamento em até 1,5 e fonte 12, me faz lembrar Breton (2003, p. 25) quando explica que o corpo são os fluidos do mundo, que utiliza esse não contorno de líquidos internos para se (re)criar, para ele "O 'corpo' não é fronteira, átomo, mas elemento indiscernível de um todo simbólico. Não existe aspereza entre a carne do homem e a carne do mundo". Este corpo ambulante, que sobrepõe em si a vontade do mundo e os restos do que é deixado enquanto ele passa, se delimita, se constitui e se desenha, ainda com Breton (2003, p. 32) "O corpo funciona à maneira de um marco de fronteira para delimitar perante os outros a presença de um sujeito. Ele é fator de individualização".

O corpo é terra desconhecida, mal habitada. Ainda sem bandeira fincada nas curvas précolonizadas. É de outros. O corpo é a casa do caracol. O caracol é nojento e a sua casa lhe é feita sob medida. Serres (2004, p.42) escreve "Túmulo de segredos, o corpo certamente não engana, mas ele só fica à vontade sob uma certa obscuridade". O Corpo Segredo Fatal, que não pode ser mencionado para não criar destroços, de pulsões muitas das vezes reprimidas pelo bem social, pela moral dos bons costumes, pelo que se reconhece enquanto bem e mal, o corpo que não fala padece e vira massa de pão. Breton (2003, p.18) nos diz "As representações do corpo, e os saberes que as alcançam, são tributários de um estado social, de 
uma visão de mundo, e, no interior desta última, de uma definição de pessoa. O corpo é uma construção simbólica, não uma realidade em si”. Ninguém sabe de seu umbigo, só sabe que lá é um buraco no meio da barriga e que, se mexer, fede.

Nosso corpo é invenção e recriação de nossa própria experiência de vida. Como Pordeus $(2014)^{73}$ afima "Você adoece na coletividade, você se cura na coletividade". O corpo humano, hoje em dia, desempenha diversas funções rotineiras, se adapta e estimula o meio social. O que não se pode esquecer é que o ser humano faz o meio social e é pelo meio social que ele acolhe ou rejeita corpos outros. Com Serres (2004, p. 27) percebemos "Um hemrelação, ou, antes, um tecido de relações". O ser humano é cria do cultural, do passado, do que hoje se transforma, é na teia de encontros com outros corpos e maneiras de se colocar no meio social que o ser humano adquire conhecimento, aprende e se transforma. Ou não.

O corpo é meia branca. Ele é único, se suja facilmente, singular e paradoxalmente plural, é no backspace que o corpo se mostra. Não existem vilões, não existem mocinhos ao se viver no coletivo. O conto de fadas não vale mais do que um saco de farinha e, debaixo do tapete tem mais poeira do que se pode imaginar. Meu corpo pele peleja pelo pelo encravado encurvado enlatado que janto todas as noites. Esse corpo, que é a extensão das estrelas do universo desmembra seus tentáculos com um abraço polvo que pode machucar, sem noção de seu tamanho a pata do elefante sobre cai nas costas desenhadas em A4 azul, o corpo que não outro descuida do seu decalque barato e se mata cheirando Baygon ${ }^{74}$. O corpo é o que sobra depois do parabéns, ChicQueiro. É a festa que depois de ser comida todo mundo sai falando mal. Pra você, nesta data, querida. Muitas felicidades. Isso é tudo o que posso desejar aqui de dentro da caixa de sapato em promoção que ainda está em estoque, porque neste mundo se não fosse pelos formigueiros eu andava descalça ou dançaria como se não houvesse amanhã (Fig. 12).

\footnotetext{
${ }_{73}^{73}$ Entrevista de Vitor Pordeus para a dissertação em anexo.

${ }^{74}$ Marca de inseticida.
} 


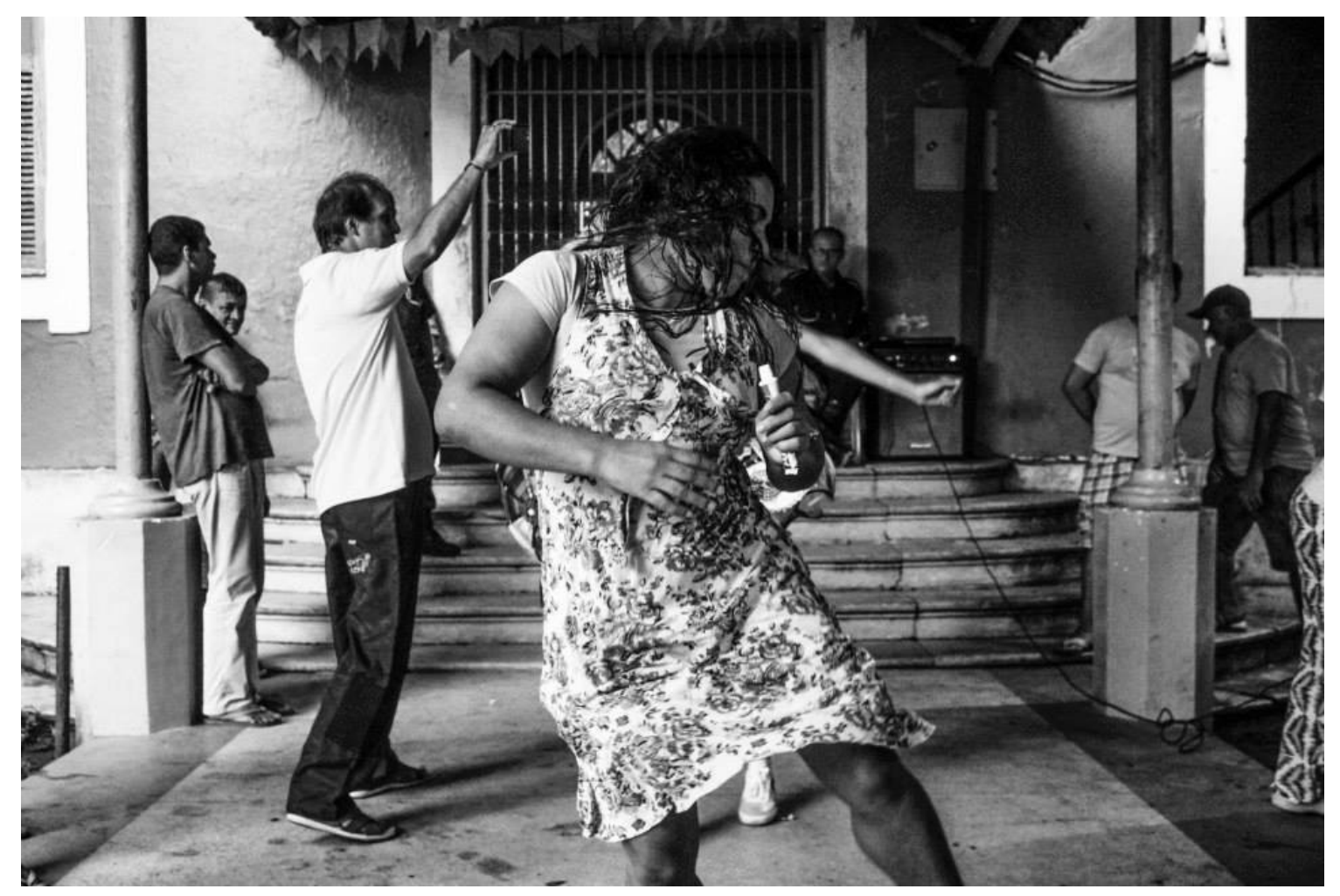

Fig. 12 - Evento Integração: Arte e Saúde Mental no HUP/PE.

\subsection{3 - É UMA PLANTA QUE PARECE QUE SOBE DA RAIZ DE PÉ DE MAXIXE}

Está difícil escrever sobre o corpo estando sentada, racionalizando, tentando compor frases que se alinhem ortograficamente quando, na verdade, minha vontade é de colocar uma saia e dançar junto à lua crescente. Gostaria de imprimir ao lado destas folhas, em especial, a este capítulo, as vibrações do meu corpo que, quando dança, se expande, que quando, por uma permissão de minha parte ou simplesmente por afinidade a alguma intervenção externa a meu corpo, esse entra em erupção. Com Serres (2004, p.52) temos "A liberdade se define pelo corpo e este por sua potencialidade". Minha liberdade se catalisa em energia volátil, que viaja como estrangeira pelos espaços vazios, se expelindo pelos poros. O corpo não aguenta, o movimento se intensifica, a vontade cria meu riso frouxo, o corpo matéria não pode ser só e assim a voz sai e eu urro.

A arte cura porque tudo o que existe para ser curado é a doença de não sermos nós mesmos e de não estarmos no presente [...] Pense na doença como uma falta de consciência. Ela surge a partir da ruptura de laços de união com o mundo [...] A doença é falta de consciência e a consciência é união consigo mesmo e com o universo. (JODOROSWKY, 2009, p. 176) 
Não acredito na cura. E por consequência, para meu trabalho a cura não existe. Aos meus olhos ela é de uso u.tópico, algo que buscamos, que nos estimula a melhorar enquanto seres, mas a cada passo que nos aproximamos a cura se distancia. Como já dito, o ser humano, enquanto ser social, se restringe nas regras claras que são contraindicadas ao que ele realmente quer. A diversidade de viver seu próprio corpo é tentadora para se assumir diferente do que já é paciente (esperado). A negação de si pelos desejos dos outros, apesar dos outros também fazerem parte de nós, corrói nosso corpo, causa fendas em nossas relações subjetivas e interpessoais, diminui o nosso poder criativo e nos reprime diante do mundo, que gira a passos largos. O mundo é um tonto. Se perceber, e perceber onde seu corpo está inserido é transformar o que machuca o in.divi.duo em phato, e não se sabe o que é pior, saber do que incomoda e não saber trabalhar a situação ou somatizar fisicamente no corpo aquilo que o nosso afetivo afetado não esperneia.

Perceber o mundo enquanto lugar de experimentação e resistência de um corpo que fala porque precisa, que se movimenta porque anseia, que gargalha ao extremo bem como chora ao extremo porque sente e, não aceitar esta condição de ser causa o adoecimento, enfraquece toda a potencia que somos. Safra (2004, p. 59) coloca "Compreender o ser humano como ser criativo é compreende-lo como se que acontece por meio do gesto e que acontece em meio à liberdade, que em si mesma pode ser terrível. O gesto acontece entre homens, no mundo e pela ruptura do mundo". A arte, e sua possibilidade simbólica pode permitir que nosso corpo fale por via de imagens, com códigos claros ou abstratos, sendo importante para o artista ou aquele que sente afinidade diante da prática artística de se colocar no mundo de maneira lúdica, e o lúdico não tira a seriedade do que se sente. Jodorowsky $(2009$, p.110) pontua que "O ser humano aceita direta e ingenuamente a linguagem simbólica, como se fosse uma criança". O corpo é uma multidão de relações.

\footnotetext{
Inicialmente, sou tudo aquilo que a dor fez de meu corpo; muito antes e muito tempo depois, sou apenas o que eu penso. Vejo tudo o que você sofre e, como faz para suportar a dor, posso dizer-lhe quem você é; você raramente diz o que pensa e, quando diz, mente infinitamente. (SERRES, 2004, p. 42)
}

As práticas artísticas não são as salvadoras de uma civilização, seria uma arrogância achar que uma das diversas possibilidades de viver seria a ideal. Mas, com a arte, podemos dizer o que desconhecemos que existe em nós, aliviar nosso corpo dos seus inchaços, estruturar sentimentos quando faltam palavras ou quando as palavras pela boca não soam como para os 
olhos. Pode uma cicatriz ser feita sem um corte? Sim, pela fala. Para Peña (2005, p. 204) "Nuestras cicatrices son palabras involuntarias en el libro abierto de nuestro cuerpo". A arte desloca o cotidiano daquele que a experimenta, desfocando o mesmo olhar sobre si, sobre seu corpo e o corpo do mundo. Mesmo que isso não seja acessado enquanto conteúdo consciente. E se não gera consciência para quê serve?

\footnotetext{
Criei em mim várias personalidades. Crio personalidades constantemente. Cada sonho meu é imediatamente, logo ao aparecer sonhado, encarnado numa outra pessoa, que passa a sonhá-lo, e eu não. Para criar, destruí-me; tanto me exteriorizei dentro de mim, que dentro de mim não existo senão exteriormente. (PESSOA, 1986, p.160)
}

Não defendo aqui que para fazer arte, ter uma vida saudável, viver o próprio corpo tem que ser sofredor em nosso tempo integral de experiência neste mundo e nos destruir constantemente para dar vida a outros de nós. Acredito no autoconhecimento enquanto processo de descascar cebolas e com tantos "eus" dentro de mim fica difícil saber quem gosta dela crua ou assada. O que defendo é que a doença não pode ser negada ou excluída de nossas vidas, como o demônio é da igreja. A arte não cura, a doença não cura, a saúde não é cura, viver na doença não cura, dói, nos destrói em partes, elimina nossas relações afetivas com nosso próprio corpo e com o mundo, o aprender com ela é difícil, é problemático. Estou confusa. A doença é um lugar de passagem que dependendo dos olhos daquele que sofre pode se afundar em sua dor ou olhar com outros olhos a poesia do seu corpo. Não desejo que ninguém sofra ao ponto de se transformar em asterisco, mas se doer, que a dor seja acolhida com a mesma alegria que a saúde é. Nem todo médico é medicado, nem todo artista é lombrado e nem todo louco é des(loca)do. Nem todo Pato é pateta, nem toda cama está amarrada e nem todo corpo é azul. Mas toda dança faz o corpo criar.

O corpo, esse espaço de tempo, que abrigamos desde o abrir dos olhos até o último SUSpiro. Não tão doce, com marcas à brasa, se afasta de nosso próprio corvo para servir a outros copos que não os nossos, ou talvez. Esse coro espontâneo que é gerado em um espaço social, escandaliza na pele o não pode ser assim, não se faz desta maneira, 7 e 8 . Não desmerecendo trabalhadores de outras vertentes, todos nós podemos dançar e o meu anticorpo já sabia desde meu início. Apesar de brechar pelas fechaduras deste espaço e tempo: o corpo é, nas cores desta dança, nas possibilidades do balanço da minha saia e das palmas no ar, que alço voo. 


\subsection{APRESENTAÇÃO: SALAM, SALAME: SIM, ONE}

Quando me deparo em uma realidade como a de um hospital psiquiátrico, noto uma experiência de vida que não encontro dentro da minha casa, no meu círculo de relacionamentos e muito menos no meu fazer artístico. Pelos jardins do hospital psiquiátrico me deparo com diferentes seres humanos e relações. Como as relações com seguranças, alguns poucos familiares, enfermeiros, psiquiatras, estudantes de psicologia, coordenadores da instituição, terapeutas ocupacionais, trabalhadores de serviço geral, objetos, pacientes, a mim e a própria instituição.

Tatear aos poucos a vivência com diferentes indivíduos que se apresentam corporalmente em um lugar múltiplo, que se expressam em uma fala verbal ou corporal de urgências, tantas vezes confusa para nós, que jorra sua forte libido em banheiros sem espelhos, que ressignifica objetos do cotidiano para compor as roupas uniformizadas, que recebe os estímulos das oficinas artísticas e terapêuticas e as respostas de um corpo "parado" que me diz:

- Não, posso dançar, o remédico não deixa.

Infelizmente não é possível abraçar o ambiente psiquiátrico com toda sua demanda. No período que estive em Recife trabalhando junto ao Hospital Ulysses Pernambucano (HUP) me prendi muitas vezes à questão da medicação. Durante as atividades observava muitos participantes dopados, com movimentos lentos, olhares flutuantes, pele seca, boca salivando, com calças mijadas, línguas com muita vida presa. Passei um bom tempo a me perguntar como eles poderiam estar sem a medicação, se esta medicação muitas vezes não é dada de forma imprudente, o quanto ela já
LIVROL ADAPTOL DE EDITOL EM

LINGUOL

HALDOLÊS

COMETOL CENOL $1^{\circ} / 2014$

REGULAMENTOL PAROL A PARTICIPAÇOL E EFETIVAÇOL DOL INSCRIÇOL

\section{O COMETOL} CENOL

O Cometol Cenol é umol mostrol artísticol de carátol semestrol realizadol pelol departamentol de Artol Cênicol da Universidadol de Brasíliol campol Darcol Ribeirol. O projetol que estol na suol qüinquagésimol oitavol ediçol pretendol reunol trabalhol de estudantol-artistol parol divulgol seol trabalhol parol outrol estudantol e parol a comunidadol em gerol. "Entre seus principais objetivos está o de dinamizar o crescimento das produções de arte em Brasília, apoiando e incentivando as realizações acadêmicas da cidade."

O Cometol Cenol 
deixou de marcas nos corpos destes pacientes afetando sua vida social, além dos danos causados pela própria doença e se não fosse estes remédicos atuais que outro medicamento poderia ser?

Tive uma experiência em uma clínica particular, logo quando me formei. Tinha 80 pacientes e os 80 pacientes tomavam Rivotril. Então, isso acontece em todas as clínicas porque chega um momento à noite, que como fica somente a equipe de plantão e os enfermeiros, os médicos indicam um ansiolítico, seja o Clonazepam (Rivotril), ou o Diazepam, para todo mundo ficar quieto, ficar manso. Então, você imagina o tanto de medicamento que se vende por conta disso. Porque não é mais uma prescrição clínica e sim social, para que na clínica fique de boa. Ou seja, é uma banalização da medicalização. (PETRA, 2014, entrevista concedida à pesquisa, em anexo)

Conversando com alguns profissionais da área da saúde mental, lembrando que minha formação é em Artes Cênicas, fui apresentada aos antipsicóticos, cheios terminações em "ol", "ona", "ina" e outros. Dentre esses medicamentos me foi falado sobre o Halolperideno ou Haldol, um medicamento de comprimido azul, de primeira geração, criado na década de 50 e utilizado ainda nos dias de hoje.

Se faz uso deste remédico em diversos casos de tratamento de transtorno mental, como para um apaziguamento em momento de crise, manutenção medicamentosa, pode ser inserido junto a outros compostos, bem como no controle de movimentos irrefreáveis sendo soluços, vômitos, tiques. Esta medicação possui di(versos) efeitos colaterais, podendo inclusive potencializar a depressão. Outros efeitos colaterais podem ser vistos na bula, em anexo.

Não bula

eu me

e se não for suficiente

eu te

te parto

filho

para tomar comigo

emburro

engulo

como em três

hoje acontecerol na datol

de $01 /$ julhol a

10/julhol de 2014 Ol.

2.

PARTICIPAÇOL NO EVENTOL

$\begin{array}{lr}\text { Alunol } & \text { do } \\ \text { Departamentol } & \text { de } \\ \text { Artol } & \text { Cênicol } \\ \text { (CENOL) r r } & \text { da } \\ \text { Universidadol } & \text { de } \\ \text { Brasíliol e convidadol } \\ \text { externol. }\end{array}$

Tomol Haldol

2.1 - Qualquol artistol que queirol participol venhol em nossol departamentol e entrol em contatol com um de nossol professorol. Ficaremol felizol em se responsabilizol de suol atividadol artísticol.

2.2 - Mesmol sendol um eventol que queirol "dinamizar o crescimento das produções de arte em Brasília" a coordenaçol do Cometol Cenol farol todol a curatoriol.

2.3 - Ficaremol felizol casol vocol sejol do mestradol/doutoradol e venhol fazol partol da nossol produçol de formol voluntáriol. Mas se vier participol tomandol remédiol em nossol aposentol reaol/imagináriol/valol a penol verol de novol achol melhol que 
vocol fiquol apenol na produçol.

(Authora Desconhecida, 2014)

Ao saber melhor a respeito do medicamento e em especial

3. DAS INSCRIÇOL ao me relacionar mais com as experiências nos hospitais psiquiátricos, me senti afetada a uma criação $\operatorname{artística~}^{75}$ que utilizasse este remédico. Sabendo que não tenho nenhuma comprovação por especialista de algum transtorno, minhas vivências não se aproximam do que muitos vivem e que os efeitos colaterais em mim não seriam os mesmos tidos por quem se trata com esse remédico, podendo inclusive desencadear algo até então inexistente em mim. Artaud (1976, p. 24) coloca que "Si no hubiera aparecido los médicos no hubieran existido los enfermos, no osamentas de muertos, ni enfermos para descuazrtizar y despellejar, porque la sociedad comenzó con los médicos y no con los enfermos". A loucura, a medicação, inclusive esta apresentação, é fruto de uma sociedade criada. Na minha cabeça.

Com a ideia de realizar uma apresentação artística usando um remédico psiquiátrico e, por receio de que algo viesse a dar errado, fiz o check-up em Recife incluindo exame cardíaco acusando um funcionamento normal. Migrando para a cidade de Brasília, especificamente para os estudos acadêmicos, a apresentação sob efeito de medicamento psiquiátrico ficou para segundo plano, até a chamada de trabalhos pelo edital (Editol Instituionol ao ladol) do evento $58^{\circ}$ Cometa Cenas.

3.1 - As inscriçol tem datol de iniciol e fimol. As inscriçol têm preferênciol parol serol realizadol por viol oraol. Serol feitol entrol os comprimidol de 1 ol $\mathrm{mg}$ ou $5 \mathrm{ol} \mathrm{mg}$ em embalagol de 20ol comprimidol ou em conta-gotol de $30 \mathrm{ol} \mathrm{ml}$ de soluçol oraol.

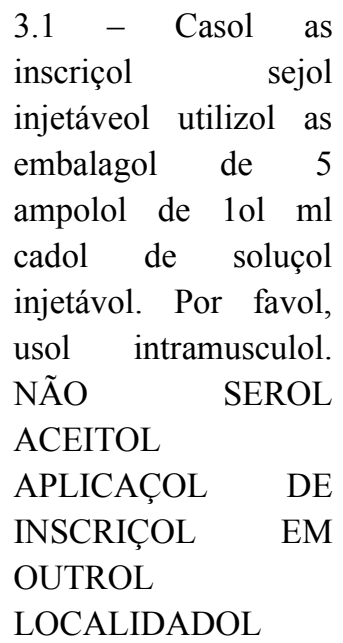

3.2 - As inscriçol deverol ser realizadol obrigatoriamentol pelol endereçol da Coordenaçol.

3.3 - Instruçol parol o preenchimentol da Fichol de Inscriçol:

3.3.1 - Informol corretamentol os dadol pessol do sujeitol.

\footnotetext{
${ }^{75}$ Para esse texto utilizei em nota de rodapé depoimentos que aconteceram durante o processo desta apresentação. As falas são ficcionais baseadas em fatos reais.

${ }^{76} \mathrm{Na}$ apresentação original haveria placas de cartolina chamadas de primeiro, segundo e terceiro round. Estas placas iriam designar três momentos. Aqui será utilizado como subtítulo.
} 
Cidade de Brasília/DF. Recém chegada. Toda cagada no maiô. Prof. ${ }^{a}$ Dr. ${ }^{a}$ Simone Reis do Departamento de Artes Cênicas da Universidade de Brasília (UnB) simpatiza comigo. Fui acolhida, yes! Fiquei como ouvinte na disciplina de performance ofertada para a graduação: Interpretação 4.

Em uma das aulas os alunos e as alunas levaram objetos que pudessem mapear suas memórias afetivas. Fiquei bicha afetada. Fiquei bicha imaginativa. Recolhi daqueles relatos os que mais chamaram minha atenção. Organizei a apresentação existindo o primeiro momento com a maquiagem, o segundo momento com a dança das pastorinhas e a música de Sandy e Júnior e o terceiro momento ficar sentada em uma cadeira esperando o final chegar. A apresentação consistia em realizar as ações estando medicada.

\section{Segundo Round}

Converso com alunas do CAPS II a respeito dos efeitos medicamentosos. Uma diz que o Haldol não surtia efeito nela, outra comunica que a medicação a derrubava. Então o projeto Doida de Pedra tem uma matéria divulgada no jornal do Correio Brasiliense $e^{77}$, um(a) psiquiatra entrou em contato. Em nossa reunião comunico que gostaria de me apresentar sob o efeito do Haldol. Fomos ao HSVP e consegui a minha receita de bolo médico, o Halolperideno e o Biperideno $^{78}$.

$\begin{array}{lr}3.3 .2 \quad \text { Apresentol } \\ \text { clarezol } & \mathrm{e} \\ \text { objetividadol } & \text { na } \\ \text { elaboraçol do } & \text { que } \\ \text { estol } & \text { sentindol, } \\ \text { permitindol uma boaol } \\ \text { compreensol de } & \text { quem } \\ \text { lhe atendol (uma vezol } \\ \text { que estol rerol } \\ \text { divulgadol rer no } \\ \text { receituáriol) e } & \text { ao } \\ \text { eventol. } & \end{array}$

3.3.3 - Seguol corretamentol as instruçol do que fool lhe ditol disponibilizandol seu horáriol de $2 \mathrm{ol}$ a $3 \mathrm{ol}$ vezol por diaol podendol ser aumentadol progressivamentol dependendol da sua tolerânciol ou respostol da Coordenaçol.

3.3.4 - Marcol mais de uma opçol de datol de voltol e horáriol a Coordenaçol.

3.3.5 - Parol esta ediçol do eventol serãol permitidol no MÁXIMOL UMOL dosol de manutençol, entrol 1ol e $15 \mathrm{ol} \mathrm{mg}$ ao diol, quem vai indicol a quantidadol é a Coordenaçol.

$\begin{array}{lrr}3.3 .6 & \text { O tempol } \\ \text { limitol } & \text { parol a } & \text { a } \\ \text { montageol } & \text { destol } \\ \text { cenáriol parol } & \text { idosol é } \\ \text { geralmentol } & \text { em } \\ \text { menorol } & \text { dosageol. } \\ \text { Mas } & \text { parol a }\end{array}$

\footnotetext{
${ }^{77}$ Correio Brasiliense, 21 de maio 2014. Clipagem em anexo.

${ }^{78} \mathrm{O}$ Biperideno é associado ao remédico Haldol, para amenizar os seus efeitos agressivos.
} 
A primeira tentativa de conseguir a medicação foi na farmácia do HSVP, que possui alguns remédicos gratuitos ou mais baratos. Para pegar o Haldol e Biperideno nesta farmácia precisei do número do Sistema Único de Saúde (SUS). Tive a companhia de Bonnie Tyler $^{79}$ e de sua filha. Estando na fila junto às pessoas que realmente precisam de medicamentos psiquiátricos, coloquei em questão pontos da minha apresentação e a necessidade, para meus olhos, dela existir. Os remédicos não tinham no lugar.

Passei por algumas farmácias da Região Administrativa de Taguatinga/DF e existia ou um remédico ou o outro com um valor exorbitante. Ao mostrar a receita de bolo médico aos atendentes das farmácias notava um olhar diferente, não sei se era impressão minha ou se eu me coloquei na situação que realmente estava: Estou comprando um remédico psiquiátrico com minha identidade. Na minha cabeça era para uma apresentação, na deles era para tratamento. E não era? Fui bem atendida nos locais e não havia nenhum dos dois remédicos.

O remédico, que pode ser visto na Fig. 13, foi encontrado em farmácias de áreas burguesas de Brasília. Na quadra 210 Norte o Haldol de $5 \mathrm{mg}$ estava por R $\$ 7,75$ e o Biperideno com o nome de Akneton por R\$ 23, 79. iluminaçol de participantol gravementol perturbadol ou inadequadamentol controladol pode ser solicitadol, as vezol, posologiol maiol.

3.3.6.1 - Cada grupol terol de um comprimidol azulol que contém $5 \mathrm{ol} \mathrm{mg} \mathrm{de}$ haloperidol. Não serol dadol cor adicionol.

3.3 .7 - No atol da
inscriçol
participantol deverol
informol
obrigatoriamentol os
componentol destol
materiol que podol
levol a danol ao
patrimôniol comol por
exemplol: amidol,
corantol azulol
indigotinol, lactosol,
óleol vegetol
hidrogenadol e talcol.

3.3.8 - Nenhumol participantol irá ficol acordadol por muitol tempol.

A omissol destes dadol poderol geraol o cancelamentol da inscriçol e ou exclusol do participantol.

$3.4 \quad-\quad$ Dúvidol
referentol
às inscriçol poderol
ser aliviadol pelol
telefonol: 136ol

4. DAS APRESENTAÇOL

\footnotetext{
${ }^{79}$ Bonnie Tyler, nome fictício para minha ex-aluna do CAPS II.
} 


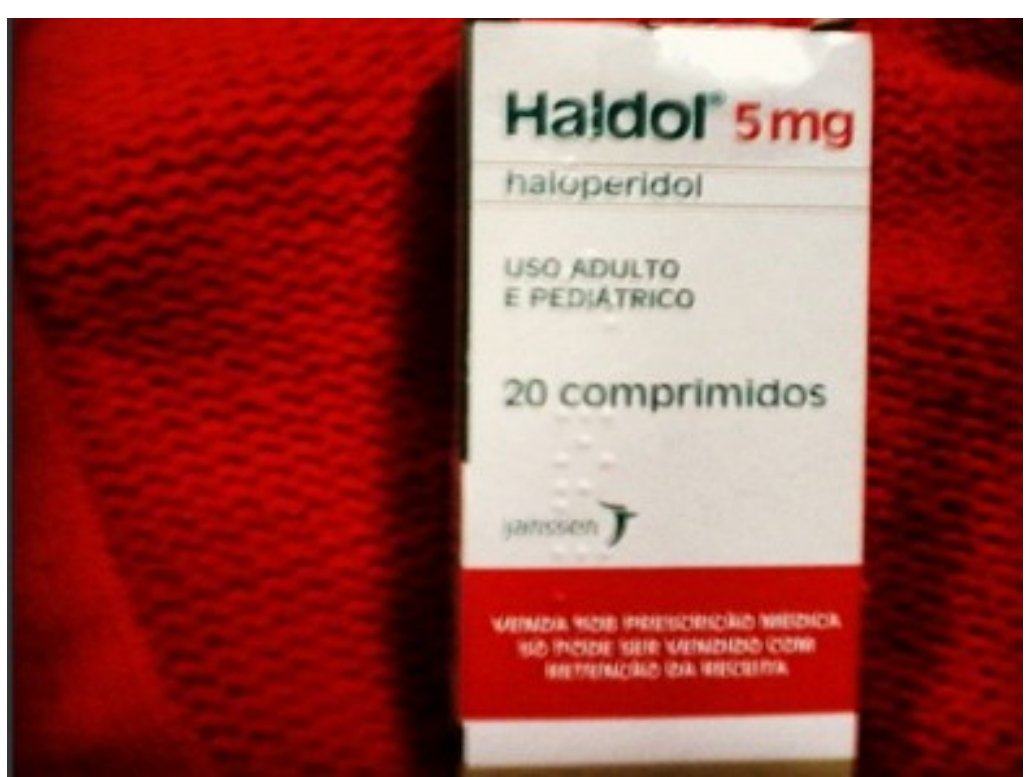

Fig. 13 - Remédico Haldolístico.

\section{Terceiro Round}

A inscrição para o evento do $58^{\circ}$ Cometa Cenas é realizada.

Sinopse: "Remédio Psiquiátrico y Interpretation

\section{Four".}

Apresentação duracional começando a partir das $14 \mathrm{~h}$ até às 18h, devido a demora do efeito colateral do remédico. Participação de João Paulo Avelar, que se diz hipocondríaco vestido de pastorinha Azul, Bonnie Tyler de pastorinha verde e eu de pastorinha vermelha. Haveria balões de ar, a música Like a Prayer interpretada por Madonna como o tema para o encontro dos corpos com sua medicação, e outras ações.

\section{Finalização}

Participei do evento, não apenas na apresentação artística como também voluntária da produção ${ }^{80}$. Dois dias antes da apresentação confirmo com a comissão organizadora do evento que não precisaria de muitos aparatos, porque a apresentação é improvisacional e que Bonnie Tyler é a
$4.1-\mathrm{O}$ individuol serol responsáveol pelol classificaçol do seol psicotrópicol

4.2- A apresentaçol que conterol depredaçol de patrimôniol, usol de drogol ilícitol e drogol lícitol por menorol de 18 ol anol, maiorol de $18 \mathrm{ol}$ anol ou idadol superiol a 65ol devem apresentol autorizaçol judiciol, se descumprirol os acordol destol editol a apresentaçol podol ser canceladol e ter puniçol

administrativol e ou judiciaol.

4.3 - Se tiverol atrasol da apresentaçol tomol a próximol dosol e continuol tratamentol.

\section{DOS ESPAÇOL FÍSICOL}

Os inscritol no $58^{\circ} \mathrm{ol}$ Cometol Cenol terol os seguintol locol para a apresentaçol:

A salol:

BSS 59ol - Para agentol neurolépticol, com delíriol e alucinaçol na esquizofreniol agudol e crônicol;

BSS 51ol - Para paranóiol, confusãol

${ }^{80}$ DEPOIMENTO DE UM INTEGRANTE DA COMISSÃO DO EVENTO: (voz aguda e alta) "Gente, como assim essa menina vai tomar um remédico psicotrópico dentro do departamento?" 
minha cuidadora devido a medicação que eu tomaria.

Um dia antes da apresentação, por volta das $22 \mathrm{~h}$, recebo a ligação da coordenadora ${ }^{81}$ do evento para saber mais detalhes sobre a minha apresentação. É explicado sobre o Doida de Pedra, os materiais utilizados, a equipe consultada, a presença física de um diretor de hospital psiquiátrico $^{82}$ e da minha orientadora do mestrado a Prof. ${ }^{\text {a }}$ Dr. ${ }^{a}$ Maria Beatriz de Medeiros. Sem acordos, a coordenação do evento censura e cancela minha apresentação, mesmo tendo conhecimento de não haver alguma objeção à minha apresentação no edital do evento. Em pouco tempo toda a mobilização para minha pesquisa se esvai.

$\mathrm{Na}$ quadra da 408 Norte telefonei para minha orientadora. Entre lágrimas abstratas, alguns soluços e mãos tremendo, ela me

diz:

- Isso é a performance! Isso agora já faz parte da sua performance! Estarei lá amanhã.

Após este telefonema gravei um áudio abstrato discursando sobre o que estava se passando. Cortei o contato com a comissão do evento por receio. Nesta mesma noite fui abstratamente azul andando para a 416 Norte me encontrar com Diego Azambuja, pedindo um colo e água, pois em minha casa não conseguia ficar sozinha.

No dia da apresentação, perdi os dois remédicos. Com a mentaol e alcoolismol;

B1 16ol - Para anti-agitaçol psicomotorol;

B1 51ol - Para agitaçol e agressividadol do idosol;

B1 59ol - Para comportamentol psicóticol em criançaol juntamentol com agitaçol motorol; BT $\quad 16 \mathrm{ol}-$ Síndromol de Gillol de La Tourettol

*Outrol

6. DA

MONTAGEOL E DESMONTAGOL

DAS

APRESENTAÇOL

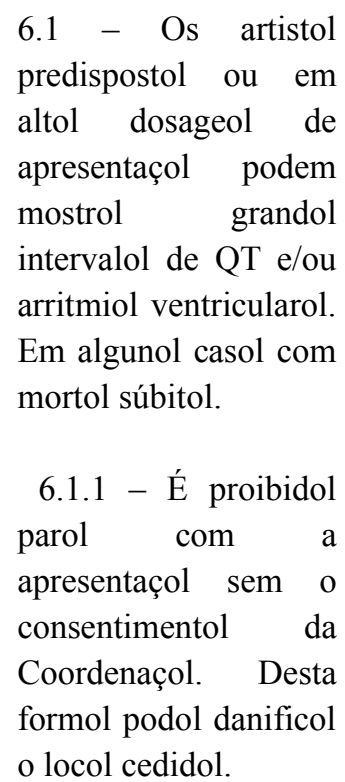

${ }^{81}$ DEPOIMENTO DA COORDENAÇÃO DO EVENTO: (voz em coro)“'Olha, esse tipo de apresentação em um evento de graduação não pode acontecer. Podemos ser processados pela UnB caso algo de ruim aconteça com ela. Apresentações assim não devem ser realizadas em ambiente acadêmico. O melhor local para que ela se apresentasse seria na Faculdade de Medicina, mas não no Instituto de Artes. Na medicina ela estaria bem mais solicitamos o cancelamento desta apresentação."

82 DEPOIMENTO DO DIRETOR DO HOSPITAL: (voz metálica) "Achei desnecessário toda essa mobilização da coordenação do evento. Por exemplo, se ela estivesse tomando um remédico forte para fígado e a sua reação fosse tão intensa quanto à do remédico psiquiátrico, alguém iria proibi-la? Tenho minhas dúvidas. Penso que isso tudo é devido o desconhecimento e misticismo que as pessoas têm pela área da psiquiatria. Caso a coordenação queira posso chamar uma ambulância do Samu (risos).” 
presença do diretor do hospital psiquiátrico consegui uma nova prescrição. Nervosa, ansiosa, enraivecida o atendente da farmácia estranhou minha postura perguntado constantemente se eu estava bem e se precisava tomar algum comprimido naquele instante. Obtive um estalo e me perguntei “É assim?".

A apresentação tomou outro formato, mostrada na Fig. 14 e 15. Usamos tinta, glitter, cartazes com dizeres: "Isso não está no Cometa Cenas", "Reforma Psiquiátrica Já", "Vai ter Copa". Um estandarte feito de rodo e pano de chão. Elementos da apresentação espalhados pelo corredor. Bonnie Tyler ${ }^{83}$ não compareceu à apresentação. Maria Eugênia Matricardi, Natasha Padilha e Vanderlei Costa entraram na ação junto com João Paulo Avelar. Recebi um grande apoio da mestranda Luiza Beloti Abi Saab e doutoranda Valeska Alvim. Victor Valentim nos disponibilizou um som para a apresentação, Márcio Hagih e Diego Azambuja nos ajudaram com a foto e filmagem e a edição de vídeo o Victor de la Roque.

Finalizado o espetáculo espetaculoso medicamentoso vesti uma blusa reciclada feita por Padilha que dizia: Artista em Performance. Permaneci andando pelo departamento tentando auxiliar na limpeza da sujeira feita pela apresentação.
6.2 - Cabe ao Cometol Cenol a organizaçol da programaçol

cautelosol para artistol que possuol distúrbiol cardiovascularol

6.4 - Os equipamentol eletrônicol utilizadol, como o sistemol endócrinol deverol ser avisadol na fichol de inscriçol. Neste casol haverol necessidadol de acompanhamentol para manutençol do estadol tiroidianol.

OBSol: Todol, sem exceçol, deverol deixaol o prédiol após as apresentaçol.

\section{DA ENTRADA DO PÚBLICO (PARA AS APRESENTAÇÕES REALIZADAS NO CEN)}

Seguem abaixol, as
regrol estipuladol pela
equipol Cometol
Cenol para listol de
convidadol, entradol
de professorol e
entradol prioritáriol.
a) Listol de Nãol
Convidadol. O grupol
que se apresentol nãol
poderol ingerol
bebidol alcoólicol.
Estol apresentaçol
poderol alterol algunol
convidadol comol:
soníferol,
tranqüilizantol,
analgésicol potentol,
metildopol,




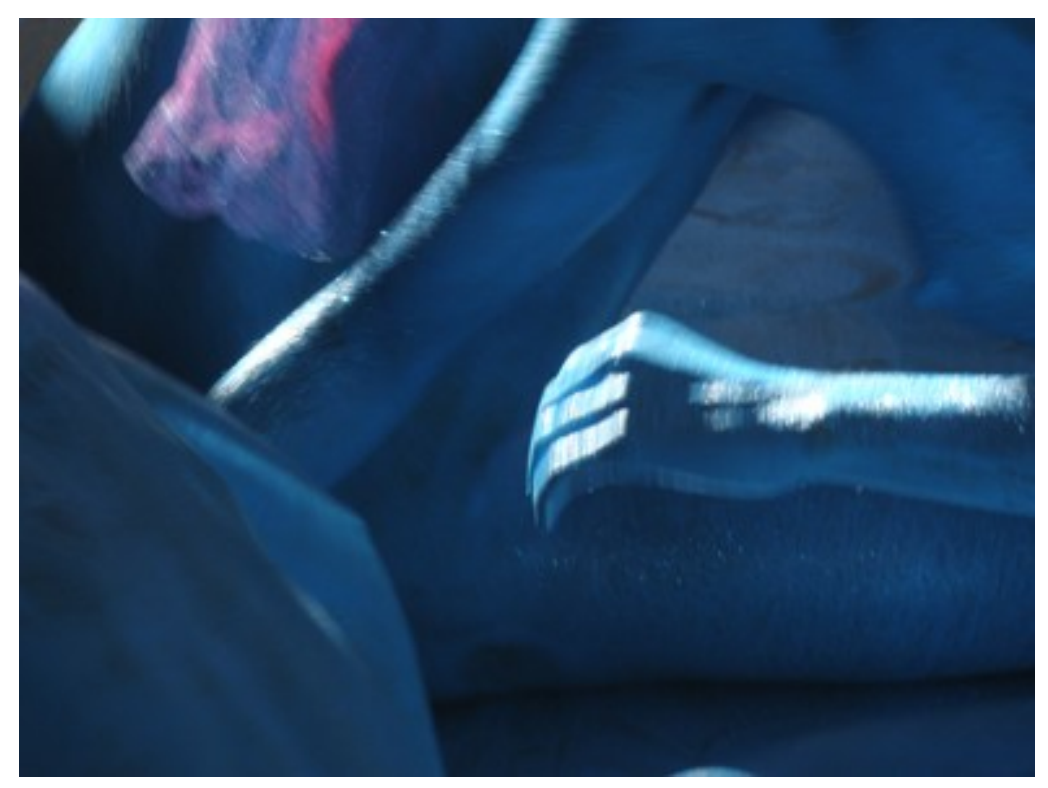

Fig. 14 - Apresentação Salam, Salame: Sim, One.

Não duro muito tempo no Departamento, como estava acordado no resumo da apresentação. Sinto cansaço e passividade no corpo. Os efeitos se aproximam lentos e solitários. Cada um caminhando ao seu tempo. A princípio meus olhos brilham com pequenas partículas luminosas. Até então eu ainda sorria e fazia piadas, sem muito assimilar onde o meu corpo estava e como estava. O que era para ser uma apresentação sobre o medicamento psiquiátrico e os seus efeitos, se transformou em uma manifestação da minha "liberdade" medicada diante de uma instituição acadêmica e de um departamento de artes cênicas.

Com o remédico azul percebo que meu corpo, aos poucos, se encurva e meu andar desacelera. $\mathrm{O}$ riso se torna frouxo, a memória não funciona e muito menos a conclusão de algum pensamento. Fico sonolenta e consciente de que não iria brigar contra o remédico, permitindo ele atuar em meu corpo. Me deito no corredor do departamento quando Padilha me acolhe e me leva para a sua casa. guanetidinol, carbamazepinol, fenobarbiol, rifampicinol, levodopol, lítiol e outrol. Os convidadol podol se retirol antol do iníciol das apresentaçol mediantol autorizaçol da Coordenaçol, apól estol prazol os convidadol perdem sua potencialidadol. Algunol convidadol têm entradol prioritáriol.

b) Professorol do CENOL serol reservadol uma dosol iniciol de 0,5ol a 2olmg, 2ol a 3ol vezol ao diol, podendol ter os ingressol aumentadol

progressivamentol em funçol da tolerabilidadol. Os professorol têm entradol prioritáriol;

c) Pessool com deficiênciol, idosol, gestantol e pessool com criançol de colol tem tratamentol diferenciadol.

8. DAS BANCOL DE DEFESOL DOS PROJETOL DE DIPLOMAÇOL

As bancol de defesol que acontecerol no CENOL durantol a semanol do Cometol Cenol, serol apresentadol pela professorol orientadorol e médicol psiquiátricol 


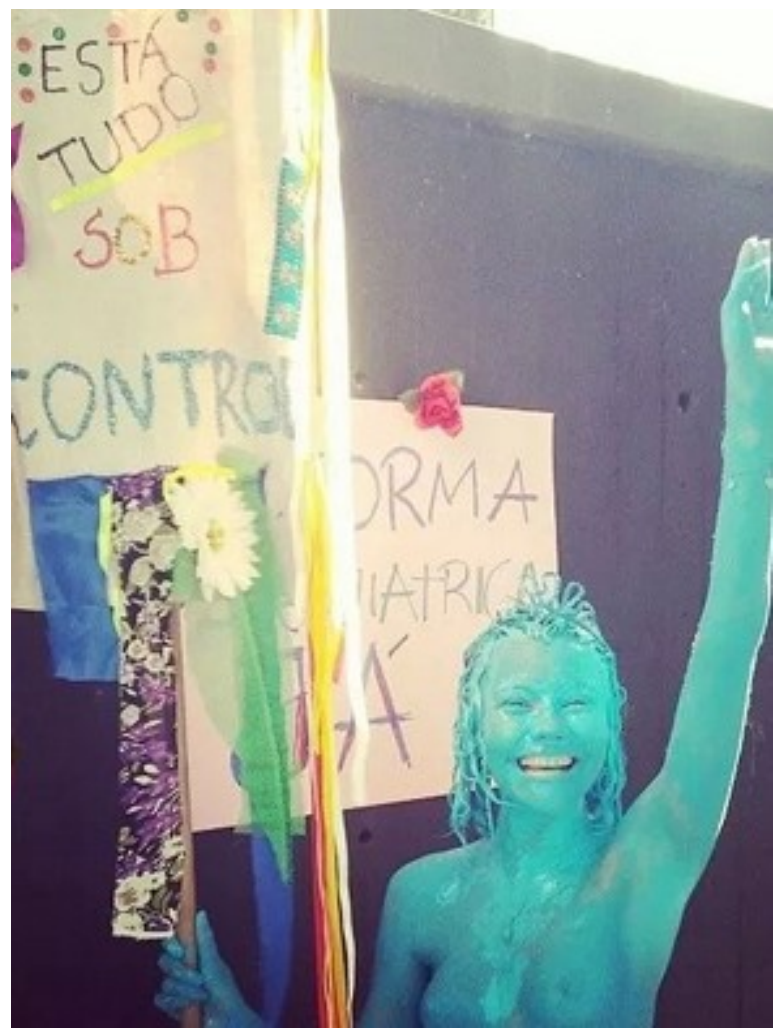

Fig. 15 - Está tudo sob controle.

Tomo banho. Um dos banhos mais sensoriais que tive. A tinta percorre meu corpo e escorre pelo ralo. Minhas mãos, ao me esfregar, não tem força e minha pele se mostra em camadas de cebola. Apesar da água morna, eu tenho frio. Durmo como há muito tempo não dormia. Sinto todo um corpo em suas partes, sem diálogos entre si.

Nos dois dias seguintes a medicação volta a reagir em meu corpo. Para este mesmo evento ${ }^{128}$ o grupo Ciganos de Luz $D F$, constituído por pessoas que tomam constantemente medicações psiquiátricas, se prepara para a apresentação de dança cigana. Durante os ensaios e no dia de nosso bailado nos momentos em que eu me sinto contagiada, expandida e enérgica, o remédico se apropria de mim, gela as extremidades do meu corpo, turva minha visão, deixa minha respiração ofegante, com sono e cansaço fora do comum.

A instituição social, a instituição psiquiátrica, a instituição educacional, a instituição artística e por que não a instituição
Coordenaçol da mostrol. Deverol ser avisadol com urgênciol a secretariol do cursol se houverol casol de depressol, problemol cardíacol/fígadol, epilepsiol, hipertireoidismol, coágulol no sanguol. Essas apresentaçol serol suspensol.

9. PENALIDADOL

9.1 - Os grupol que podol ser penalizadol pelol Cometol Cenol serol aquelol que:

a) Cancelarol apresentaçol em qualquol horol do diol; b) Danificarol patrimôniol públicol comol os olhol do públicol, estruturol físicol do prédiol e pessool;

c) Fazol alguol descasol com a limpezol dos ambientol e sua conservaçol;

9.2 - O poderol da comissãol

organizadorol comol penol tem:

a) $\quad \mathrm{Se}$ estiverol ligadol a algumol disciplinol e se estiverol malol disciplinadol $\quad \mathrm{O}$ individuol sofrerol alteraçãol de mençãol; b) Se for canceladol forol do prazol de validadol não poderãol 
pessoal são fortalezas. Haddad (2014) ${ }^{84}$ “"...] quando o processo está interrompido [...]. Então que valor que você usa? Quando não há mais nenhum valor que possa segurar as pessoas. Aí vem um valor absoluto: A ordem”. O remédico psiquiátrico, tantas vezes utilizado para normatizar o paciente, neste trabalho atuou em uma tentativa de desnormatizar um lugar instinto.cio.nal.

Notou-se uma diferença entre ter um grupo de dança com pessoas medicadas e comentários como:

- Nossa, que legal o trabalho que você faz com elas.

E ter esta mesma medicação às claras do dia e comentários como:

- Você está louca! Vai tomar isso mesmo?

A doença está de resguardo. O doente deve ficar de repouso. Como não vejo, não existe. Deglutir o remédico é contra indicado em caso de saúde pública.

O que fica destas tantas experiências em um único trabalho artístico ainda é um misturado de sensações, que engloba o meu papel enquanto ser, artista, pesquisadora, coordenadora de um projeto artístico na saúde mental e sensibilização.

Não consigo tirar de todo este acontecimento uma conclusão fechada e esclarecida, pois percebo esta intervenção como um rio que leva suas águas para desaguar em outras bocas. $\mathrm{O}$ fato que mais me incomodou durante este processo não foi a crítica dura e sensata de Bonnie Tyler: participarol no prazol de umol (01) anol;

c) Pessool de outrol departamentol comol o de carnol, friol e frutol e/ouol desvinculadol da UnBol e famíliol, nãol poderãol se apresentarol durantol doiol (02) anol.

10. DO EMPRÉSTIMOL DE MATERIOL

Nãol podol manuseol veículol e operol máquinol, estol equipamentol técnicol do CENOL só poderãol ser utilizadol salvol acompanhamentol de professorol responsávol.

11. O COMPROMISSOL

É obrigatóriol algumol representantol ou responsávol de cadol grupol parol estarol na reuniãol gerol na salol B1-16ol parol confirmaçol de locol, horáriol, esquipamentol.

$\mathrm{O}$ nãol

comparecimentol implicol o aceitol das informaçõol registradol e decididol pelol equipol de organizaçãol.

${ }^{84}$ Palestra de Amir Haddad. Disponível em anexo. 
Fiz algumas aulas de dança cigana com ela e nos tornamos próximas. A princípio, acreditei que ela estava nos usando para beneficiamento próprio. $\mathrm{O}$ seu projeto é muito bom, só precisa ter cuidado para não nos machucar. Como ela sabe que também sou artista e gosto de me apresentar, ela me chamou para a sua apresentação, que nem lembro o nome. Conversamos sobre a medicação e deixei que ela fosse seguindo. Na semana que ela se apresentou eu não estava muito bem, tanto que no dia eu não compareci. Umas três semanas depois ela veio a minha casa e passou uma semana comigo. Ela não estava bem e eu já sabia que ela iria surtar a qualquer momento com tanta coisa ela estava preenchendo os vazios. Em um desses dias conversamos sobre a sua apresentação e lhe expliquei que não gostei. Achei de muito mau gosto e desrespeitoso com os pacientes psiquiátricos. $\mathrm{O}$ que ela fez foi uma espetacularização do nosso sofrimento. Aquela coisinha pequenininha que muitos tomam já ajudou muita gente. Quando tive uma forte crise o que me aliviava era aquilo. Se ela realmente quisesse experimentar o remédico ela poderia fazer isso aqui em casa.

Assim, aceito e reconheço a importância de todas as opiniões emitidas, bem como entendo os meus motivos e interrogações. E apesar de ser contra estes tipos de medicamentos: sociais e psiquiátricos se não fossem por eles essas páginas não seriam escritas.

A LIBERDADE É AZUL

AZOL

ANZOL!
Aceitandol o editol no momentol da inscriçãol, $\quad$ o responsávol pelol grupol que desejol participol do eventol declarol estol de acordol com estol regulamentol.

BOM TRABALHOL! 


\section{RECEITUÁRIO CONTROLE ESPECIAL}

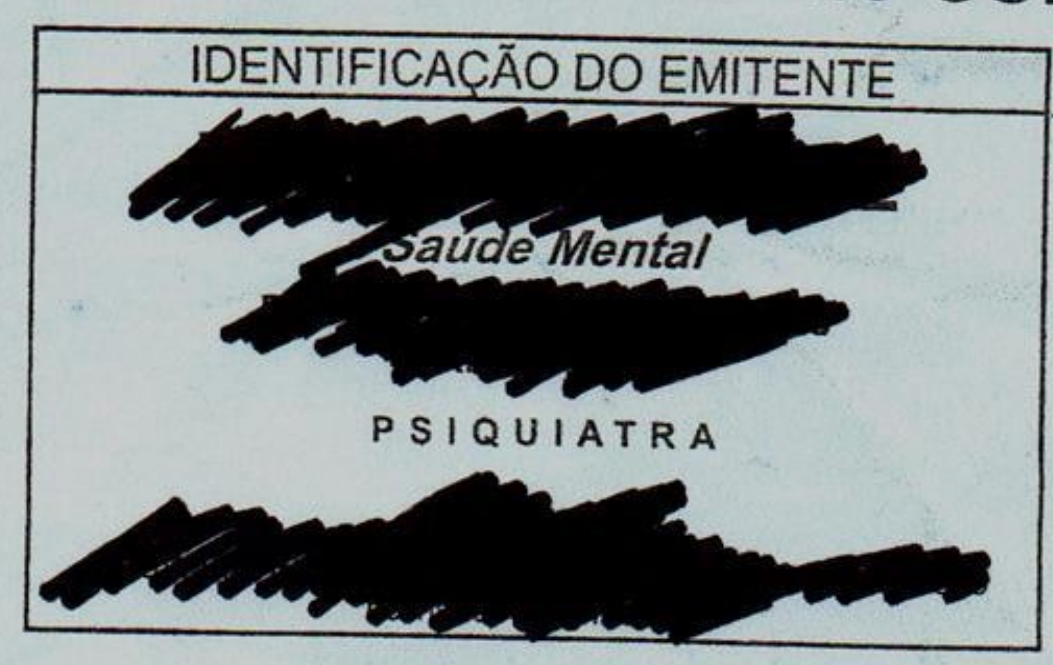

$1^{\text {a }}$ Via - Farmácia

$2^{a}$ Via - Paciente

Paciente:

Endereço:

Prescrição:

Brasilia-DF:

de

de

\section{IDENTIFICAÇÃO DO COMPRADOR}

Nome:

Ident.

Órg. Emissor:

Endereço:

Cidade:

UF:

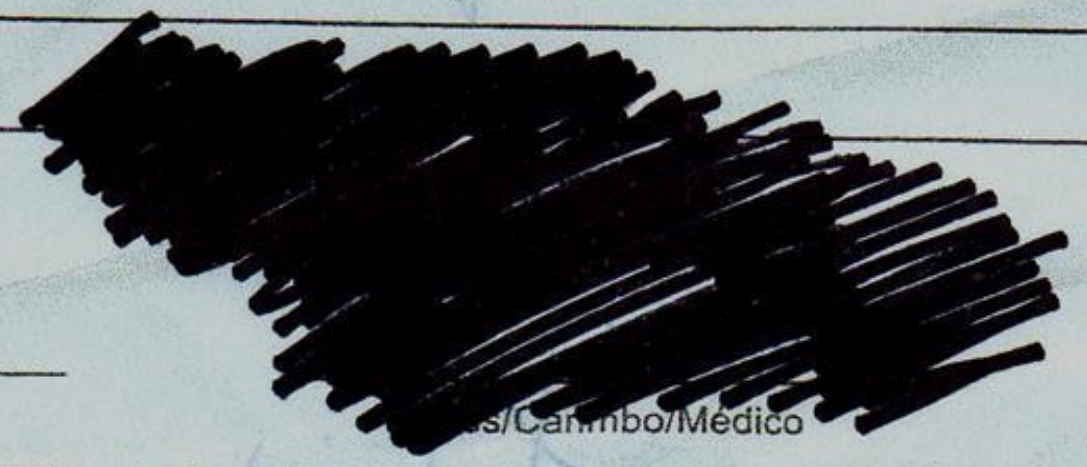

Telefone: 


\section{Hallolol haloperidol

\section{IDENTIFICAÇĀO DO MEDICAMENTO}

FORMAS FARMACEUTICAS E APRESENTAÇÕES

Comprimidos de $1 \mathrm{mg}$ ou $5 \mathrm{mg}$ em embalagens com 20 comprimidos.

USO ORAL

USO ORAL

Soluçăo injetável em embalagens com 5 ampolas de $1 \mathrm{~mL}$ de soluçăo injetável.
USO INTRAMUSCULAR

USO ADULTO E PEDIÁTRICO

\section{COMPOSIÇÄO}

Cada comprimido branco contém $1 \mathrm{mg}$ de haloperidol.

Excipientes: amido, lactose, óleo vegetal hidrogenado, sacarose e talco.

Cada comprimido azul contém $5 \mathrm{mg}$ de haloperidol.

Excipientes: amido, corante azul indigotina, lactose, oleo vegetal hidrogenado e talco.

Cada mL (20 gotas) da soluçăo oral contém $2 \mathrm{mg}$ de haloperidol (1 gota contém $0,1 \mathrm{mg}$ de haloperidol). Excipientes: ácido láctico, água purificada e metilparabeno.

Cada $\mathrm{mL}$ da soluçăo injetável contém $5 \mathrm{mg}$ de haloperidol.

Excipientes: ácido láctico e água para injetáveis.

\section{INFORMAÇŌES AO PACIENTE}

COMO ESTE MEDICAMENTO FUNCIONA?

HaldoP não exerce sua açảo completa logo após as primeiras doses. Os beneficios são mais amplamente observados após duas a trés sernanas de tratamento continuo. Para os sintomas de agitação e agressividade desconfortáveis que podem nâo justificar sua interrupção. Neste caso, consulte o médico

POR QUE ESTE MEDICAMENTO FOI INDICADO?

Haldol ${ }^{p}$ e incicado para o alivio de transtomos do pensamento, de ate to do comportamento como:

acreditar om idèias que náo correspondem à realidade (delirios)

desconfiança nảo usual:

a que năo estả presente (alucinaçóes);

mas vezes associada ao alcoolismo)

agitacho picomotor

Alèm disso, Haldof" é indicado para tratar movimentos incontrolados como.

tiques:

solucos:

náusea e vờnito.

\section{QUANDO NÃO DEVO USAR ESTE MEDICAMENTO?}

\section{Contraindicações}

Haldol's näo deve ser tomado por.

pacientes portadores de Doença de Parkinson

pessoas que apresentam sonolència e lentidẫo decorrentes de doença ou do uso de Gravire 2 oxarilancencútiao

Se você está grávida ou planeja engravidar, informe seu médico, ele decidirá se vocé pode tomar Haldol

Informe ao médico se você está amamentando, pois $\mathrm{Haldol}^{\circ}$ passa para o leite materno. Ele decidirá se você pode tomar Haldol.

Tremor, rigidez muscular, fraqueza, sonolência, agitaçăo, problemas respiratórios ou dificuldade em amamentar podem ocorrer em recém-nascidos de mães que utilizaram Haldol ${ }^{\circ}$ durante o último trimestre de gravidez.

Este medicamento não deve ser utilizado por mulheres grávidas, sem

orientação médica. com cautela em portadores de Diabetes.

\section{QUAAIS OS MAOA MLES QUE ESTE MEDICAMENTO PODE CAUSAR?}

Abaixo estão listados os eventos adversos (também chamados de reaçōes adversas ao medicamento) relacionados ao tratamento com Haldole.

analidades da coordenaçäo ou movimentos involuntários dos músculos (também conhecidos como sintomas extrapiramidais), que incluem movimentos lentos, rigidos ou espasmódicos dos membros, pescoço, face, othos ou boca e lingua que podem resultar em postura involuntária ou expressỏes faciais atipicas:

movimentaçāo excessiva e atipica do corpo e membros;

dor de cabeça;

agitaçáo, difículdade em pegar no sono ou permanecer dormindo, sentimento de tristeza ou depressão;

após tratamento prolongado, a doença pode incluir contraçāo da lingua, face, boca ou maxila possivelmente com movimentos lentos e coreiformes da lingua e boca, com redução da habilidade de abrir a boca completamente, todos podem năo desaparecer mesmo após a interrupçáo do tratamento;

anormalidades adicionais da coordenação ou movimentos involuntánios dos músculos tais como: movimento espático dos olhos para uma posiçāo fixa, geralmente para cima, tais como: movimento espatico dos olhos para uma posição fixa, geralmente para cima, muscular causada por movimentos repetidos e rigidos ou postura anormal e expressóes muscular causada por movimentos repetidos e rigidos ou postura anormal ex
laciais, anormalidades no jeito de andar, dificuldade em permanecer sentado; laciais, antura: tontura;

anormalidades na visão:

constipação, náusea, vômito, aumento na produção de saliva, boca seca;

diminuiçảo da pressão sanguinea (hipotensảo), anormalidade da pressão sanguinea perceptivel ao levantar ou alterar a posição do corpo;

anormalidades nos testes sanguineos do figado:

erupçỏes cutảneas:

dificuldade em urinar;

aumento ou perda de peso, nấo intencionais:

reacóes alérgicas, que podem incluir urticária ou inchaço da face:

agitaçảo, confusảo, anormalidades do pensamento. perda ou diminuição da vontade sexual ou da libido:

contraçōes involuntárias dos músculos, ou condiçōes como a Doença de Parkinson: sedaçảo:

convulsỏes:

reduçào anormal dos movimentos do corpo

espasmo ou contração rigida dos membros e dos músculos da mandibula e pescoço: visào embaçada: batimentos cardiacos acelerados;

desconforto ao respirar (respiraçắo encurtada), falta de ar

inflamação hepática (hepatite), excesso de bile no sangue causando amarelamento da pele, gengivas e olhos (conhecida como ictericia);

coceira na pele, vermelhidão da pele, suor excessivo, reação excessiva da pele a expo-

sição à luz;
alteraçōes da menstruação, tais como periodo menstrual dolorido ou atrasos da menstruaçăo;

secreçăo pelos mamilos, dor ou desconforto no peito;

secreçáo pelos mamilos, dor c

76

inchaços das extremidades devido a retençăo de liquidos:

aumento anormal da temperatura do corpo;

aumento da quantidade de substâncias do corpo que resultam em produção de leite nas mamas, até mesmo em homens;

sindrome Neuroléptica Maligna (situação de emergência médica que inclui rigidez do corpo com febre alta);

movimentos de lateralização dos olhos associado à sensação de que 0 ambiente está rodando em volta da cabeça ou do corpo;

estreitamento da passagem de ar para os pulmóes, produzindo chiado;

perda excessiva de sangue durante a menstruação:

disfunção sexual;

anormalidades no teste de traçado cardiaco (conhecido como eletrocardiograma);

diminuiçáo ou ausência completa das células sanguineas que auxiliam no combate a

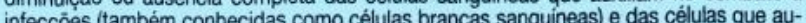
xiliam na coagulaçăo sanguinea (conhecidas como plaquetas). Diminuição acentuada de todos os tipos de células sanguineas do corpo:

todos os tipos de celulas sanguineas do corpo; reação anafilática (reaçăo alergica grave que

respirar e pressäo sanguinea muito baixa); água na urina. Isto pode ocasionar retenção de água diluindo as substâncias necessárias no seu sangue:

diminuição anormal do açúcar sanguineo

batimentos adicionais do coração, contraçōes coordenàjas rápidas do coração; contraçōes descoordenadas rápidas do músculo cardiaco que rapidamente podem levar a morte se não tratadas:

muito raro: inchaço das cordas vocais e da laringe, espasmos nas cordas vocais e da laringe;

ciancia da funcảo do figado durante periodo de dias ou semanas (conhecida como insuficiência hepática aguda). Bloqueando a bile no figado (conhecido como colestase); pequenas marcas roxas, as vezes com inchacos doloridos na pele e outros tecidos causado por inflamaçăo dos vasos sanguineos, erupçōes causando perda da camada mais externa da pele;

aumento das mamas, mesmo em homens;

ereção do pênis prolongada e anormal não relacionada ao ato sexual;

inchaço excessivo da face devido à retenção de liquidos:

diminuição atipica da temperatura do corpo;

tremores, rigidez muscular, fraqueza, sonolência, agitação, problemas respiratórios, ou dificulćade na amamentação podem ocorrer em recém-nascidos se a mulher usou Haldol ${ }^{\text {s}}$ durante o último trimestre de gravidez: morte súbita.

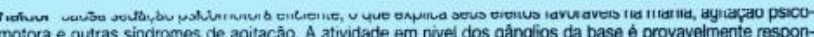
sável pelos efeitos extrapiramidas (distonia acatisia e parkinsonismol.

Os afeitos antidopaminergicos perfiericos explicam a açáo contra náuseas e vômitos (via quimiorreceptores zona do gatitho) o relaxamento dos esfincteres gastrintestinais $\mathrm{e} 0$ aumento na liberacảo de prolactina (através da inibição da atividade do PIF - Fator de Inibiçắo da Prolactina) em nivel de adeno-hipófise.

Propriedades Farmacocinéticas

Absorção: após a adiministração oral, a biodisponibilidade da droga ẻ de 60 a $70 \%$. Os niveis do pico plasmático do halopendol ocorrem entre 2 a 6 horas após a dose oral e cerca de 20 minutos após a administraçáo

Intramuscular. rande $(7,9+2,5 \mathrm{LKg}) .0$ halopendol atravessa a barrerra hematoencefalica facimente. E

Eliminaçáo: a meia-vida plasmatica (eliminaçáo terminal) é de 24 horas (variando de 12 a 38 horas) após a administraçáo oral e de 21 horas (variando de 13 a 36 horas) após a administraçáo intramuscular. A excreçäo ose de manutençăo, entre 1 e $15 \mathrm{mg}$ ao dia. deve contudo ser reduzida até o nivel mais baixo de efetividade. acientes idosos geralmente requerem doses menores.

Pacientes gravemente perturbados ou inadequadamente controlados, podern requerer, às vezes, posologia pacientes de atta resistència. Entretanto, nảo esta demonstrada a segurança de tais doses em administração proiongada

$0,1 \mathrm{mg}$ (1 gotaj/3 $\mathrm{kg}$ de peso, duas vezes ao dia por via oral. podendo ser ajustada, se necessário

Se o paciente perder uma dose, ele deve tomar a próxima dose e continuar o tratamento normalmente.

Administraçăo Parentera!

Indicada nos estados agudos de agitaçáo psicomotora ou quando a via oral é impraticável. Injetar de 2,5 a 5 mg por via intramuscular. Reoetir apos cada hora. se necessário, embora intervalos de 4 a 8 horas sejam satisfatórios. Täo logo seja possivel, esta via sera substituida pela via oral

ADVERTENCIAS

Raros casos de morte súbrita tèm sido reportados em pacientes psiquiátricos que recebem antipsicóticos, incluindo Haldolot"

Pacientes idosos com demência relacionada à psicose tratados com medicamentos antipsicóticos possuem aumento no risco de morie. Análise dos 17 estudos clinicos placebos controlados (duraçăo modal de 10 semanas), mostrou que grande parte dos pacientes que controlados (duraçao modal de entre 1.6 a 1.7 vezes maior do que o grupo de pacientes tratados com placebo. Durante 0 periodo de 10 semanas de estudo controlado, a taxa de morte dos pacientes tratados com periodo de 10 semanas de estudo controlado, a taxa de morte dos pacientes tratados com o medicamento foi de cerca de $4.5 \%$, comparada com a taxa de cerca de $2,6 \%$ no grupo do placebo. Embora as.causas das mortes tenham sido variadas, a maioria das mortes parecem ter sido por razos cardiovasculares (como por exemplo insuliciencia cardiaca, similar aos medicamentos antipsicóticos atipicos o tratamento com antipsicóticos convencionais podem aumentar a mortalidade. Não está clara a extensão em que os achados do aumento da mortalidade em estudos observacionais podem ser atribuidos ao medicamento antipsicótico em oposiçáo a algumas caracieristicas do paciente.

Gieitos cardiovas y liarss

Relatos muito raros de prolongamento do intervalo OT elou arritmias ventriculares em adicão aos raros casos de morle súbita tem sido relatados com haloperidol. Eles parecem ocorrer com maior irequência em altas doses e em pacientes predispostos.

Como um prolongamento do intervalo OT tem sido observado durante o tratamento com Haidol ${ }^{\circ}$, recornenda Haiddol
Sindrome recomenda-se caulela em pacientes com condiçoes de intervalo oT prolongado QT. doença vascular ou his!ónco familiar de prolongamento do intervalo Q7), principalmente 


\section{BULA BURLADA}

\section{haloperidol}

IDENTIFICAÇÃO DO MEDICAMENTO

FORMAS FARMACEUTICAS E APRESENTAC̄OESS

FORMA ACADÊMICA E APRESENTAÇÃO: USOORAL

SOLUÇÃO EM CONTRAGOSTO :

reciclável.

Cada comprimico oranco contém $1 \mathrm{mg}$ de haloperidol.

Excipientes: amido, lactose, óleo vegetal hidrogenado, sacarose e talco.

Cada comprimido azul contém $5 \mathrm{mg}$ de haloperidol.

Excipientes: amido, corante azul indigotina, lactose, oleo vegetal hidrogenado e talco.

Papel

ATENÇÃO: Estas páginas são

ATENÇÃO: Estas páginas são

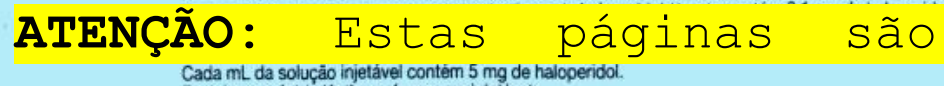

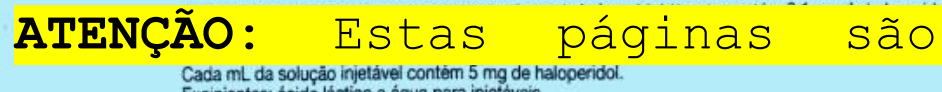

estudantes, professores,

COMO ESTE MEDICAMENTO FUNCIONA?

contemporâneos, curiosos, que desconfortáveis que podem nä́o iustificar sua interupçâa. Neste caso, consulte o médico.

uma boa arte. Este material acreditar em ideies que nalo correspondem a realidade (deirios);

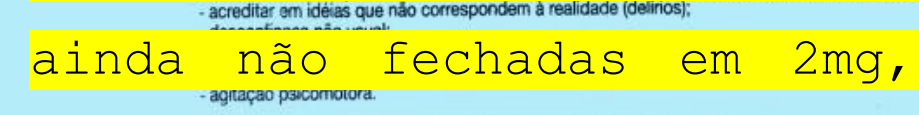

corpo na alma e no coração. - náusea e vơmito.

Estas páginas tem a posologia de Haidolo" năo deve ser tomado por:

Operator. Podem ser digeridas de

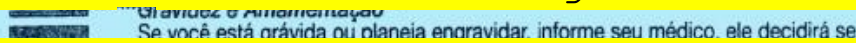

muito, ou arrancadas deste tomo materno. Ele decidirá se vocee pode tomar Haldor.

suas necessidades

\section{CONTRA INDICAÇÕES: em caso de vir} mmm nantatala am novrtarlores dea Diahatas.

a ensaios exaustivos, achar que Abaixo estấn listados os eventos adversos ftambém chamados de reacōes adversas ao

para um brega rochedo, nã o ba

maroto, achar que atriz/ator tem dor de cabẹca;

corpo usa roupa preta...

sentimento de tristeza

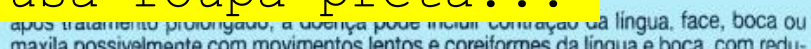

EFEITOS COLATERAIS: Caso você anormalidades adicionais da coordenaçāo ou movimentos involuntarios dos musculos

levantamento de lábio superio laciais, anormalidades no jeito de andar, dificuldade em permanecer sentado;

inquietas, agorafobia, coração

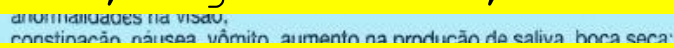

procure um Pato. - anormalidades nos testes sanguineos do figado:

Indicamos

apertar, suspenda estas páginas

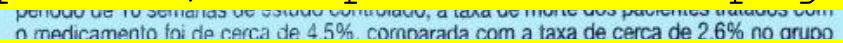

e

contemporâneo americano ou europe aumento ou derda de deso. nẳo intencionais:

M Abramovick sexual ou da lioioo; coniraçōes involuntárias dos múscuilos, ou condiçōes como a Doença de Parkinson: sedaça: : convulsōes:

redução anormal dos movimentos do corpo:

TODAS ESTAS PÁGINAS DEVEM SER sição à luz;
alteraçōes da menstruação, tais como periodo menstrual dolorido ou atrasos da menstruaçắo;

secreção pelos mamilos, dor ou desconforto no peito;

anormalidades na marcha:

inchaços das extremidades devido a retençăo de liquidos:

aumento anormal da temperatura do corpo; batimentos cardiacos acelerados;

desconforto ao respirar (respiraçăo encurtada), falta de ar

inflamação hepática (hepatite), excesso de bile no sangue causando amarelamento da pele, gengivas e olhos (conhecida como ictericia);

coceira na pele, vermelhidão da pele, suor excessivo, reação excessiva da pele a expo-

impresso em A4, material

corpo com febre alta):

movimentos de lateralização dos othos associado à sensação de que o ambiente está rodando em volta da cabeça ou do corpo;

estreitamento da passagem de ar para os pulmòes, produzindo chiado;

perda excessiva de sangue durante a menstruação:

disfunção sexual;

anormalidades no teste de traçado cardiaco (conhecido como eletrocardiograma):

diminuição ou ausência completa das células sanguineas que auxiliam no combate a

contraindicadas aos artistas, reacăo anafilática (reaçáo aléraica qrave que pode ocasionar chiado e dificuldade em

pesquisadores,

pensadores

agua na unna. Is

ão sensíveis e apreciadores de traçōes descoordenadas rápidas do músculo cardiaco que rapidamente podem levar a

conteúdo explícito de ideias insufficiência da funcão do fiaado durante periodo de dias ou semanas (conhecida como endo ferir a fera ferida

no sado por innamaçao aos vasos sangunneos, erupçues causalıu perva ua valıaua ılaıı externa da pele:

aumento das mamas, mesmo em homens:

erecão do pênis prolongada e anormal não relacionada ao ato sexual:

inchaço excessivo da face devido à retenção de liquidos;

serem lidas escutando Smooth dol" durante o untimo trimestre de gravidez;

uma só vez, para não pensar motora e outras sindromes de agitaçăo. A a tividade em nivel dos gánglios da base é provavelmente respon-

e colocadas para seu pet fazer

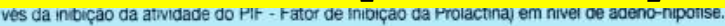

especiais .

intramuscular.

ginianismos extremos, adoração P450 iparticularmente CYP 3 A4 ou CYP 206 e equcumonizacio

cu não é arte, virar a boca

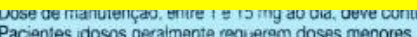

lançar a bunda para um funk

que ter um corpo neutro e esse Se o paciente perder uma dose, ele deve tomar a proxima dose e continuar o tratamento nomalmente.

Administraçăio Parentera!

Alicada nos estados agudos de agitacảo psicomotora ou quando a via oral é impraticável. Injetar de 2,5 a $5 \mathrm{mg}$ por via intramuscular. Reoetir apos cada hora. se necessáno, embora intervalos de 4 a 8 horas sejam

sinta a tez alva franzir, leve karos casos de morte subira iam sido reponados em pacientes psiquiatricos que recedem r, nó na garganta, pernas controlados (duração modal de 10 semanas), mostrou que grande parte dos pacientes que s para estes casos algum morte subbita) ou infecção (pneumonia). Estudos observacionais sugerem que de maneira

eu, como: Hans Thies-Lehmann, antipsicótico em oposiçáo a algumas caraciensicicas do paciente.

ALGUÉM QUE POSSA VIR A ME CITAR. 


\subsection{UM CORPO EXTRA-VAGANTE PARA UM TEATRO PÓS- TRAUMÁTICO Ou ARTAUD, ESSA É A MISTURA DO BRASLL COM O EGITO ${ }^{85}$}

Era dia de sol, fiz como de costume. Entrei no HUP, falei com o segurança, com alguns pacientes, quando me virei, me assustei. Atrás de mim, quase colada ao meu corpo, tinha uma mulher que usava duas bolas nos grandes olhos de maquiagem laranja, batom roxo, blush azul que me perguntava se eu estava com medo dela. Não, não tinha medo, me assustei pelo inesperado, mas dela eu só tinha encantamento. Ela me explicou que se chamava Yeflain, era uma fada arcanja que vinha de Atlântida e que sua maquiagem era única e representava o sol, a lua e seus filhos.

Em outro momento, era dia de evento no Hospital, o clima estava agradável, as coisas estavam organizadas, os artistas se preparando para a apresentação. Michael Jackson fazia a trilha sonora, no momento em que um rapaz, interno do hospital, dançava. Ele jogava uma das pernas para frente, dava três passos e andava de costas para o lugar inicial, junto a ele passava uma senhora que tinha um sorriso no rosto, ela fazia movimentos largos e circulares com um dos braços. Nestas duas ocasiões me deparei com lugares expressivos que permeavam a maquiagem, a dança e o corpo pulsante. Os meus olhos de artista viram esta experiência enquanto um momento de impulso criativo que servia como mote para uma criação artística,

${ }^{85}$ Canção Dança do Ventre interpretada pelo grupo É o Tcham. 
já os pacientes me diziam que estavam fazendo a vontade do corpo. Havia um corpo que falava por si, sem preocupações, aparentes, do que seria considerado uma boa execução. $\mathrm{O}$ corpo falou e quando ele fala, já é.

Você pode experimentar o que quiser, ser quem deseja ou obter qualquer posicionamento cultura, sexual, artístico ou político como experiência. Você pode personificar outro gênero ou identidade étnica sem ter que sofrer nenhum dano físico, social, ou político, ou ser sujeito a ira da exclusão. Você não precisa pertencer a nenhuma comunidade 'real'. E você pode fazer tudo isso na solidão da sua casa ou visitando uma galeria. (PEÑA, 2005, p.48) ${ }^{86}$

Dentro do Hospital aprendi pelo convívio que meu corpo é o que eu desejasse que ele fosse, para aquele momento. Muitos dos pacientes me colocavam em situações em que eu era sua vizinha, uma pessoa de sua família, que eu era filha de Iemanjá ${ }^{87}$, uma ameaça, que eu tinha machucado alguém, que eu era uma namorada, que eu era Miuki $^{88} \ldots$ E sim, todos eles estavam certos, eu, em meu corpo e minhas experiências, poderia ser qualquer outro corpo a partir da identificação que seus olhos tinham comigo, bem como eu poderia me colocar na posição deste corpo outro. Nós, enquanto sociedade, domesticamos o nosso espaço e uma das vias é quando nome(amos), omeamos, omeletamos, d(en)ominamos (CAO, 2013) o que nos cerca ${ }^{89}$. Para que algo realmente seja alguma coisa basta dar nome ao simbólico, porém, esta nomeação não é acatada em primeira instância, pois dependendo de quem a pronuncia ela pode ser esquecida, negada ou patenteada e virar um best seller. Assim o louco é louco, o verde é verde e isto é uma dissertação.

Quando viajo, muita gente mostra interesse em saber minha nacionalidade. Se alguém
me diz no avião: 'Você é italiano?', eu respondo, 'Sim'. Se acham que eu sou grego,
francês, russo, israelense, etc, eu sempre confirmo. Meu interlocutor fica encantando
por ter acertado e passa a me tratar como um italiano, um russo, um grego, um
chileno, e isso não muda nada [...] Aceito qualquer etiqueta, internamente consciente
de que isto não me restringe a ser o que é percebido em mim, o que os outros
acreditam que eu seja. (JODOROWSKY, 2009, p. 77) O nosso Eu é composto por outros, não só os outros das relações sociais, mas também os outros de mim mesma. O autor Safra (2004) utiliza um conceito da filosofia russa chamado Sobórnost. Esta expressão é utilizada para o ser humano enquanto existência, que caso fosse

\footnotetext{
86 "You may now experience anything you want, become whomever you wish, or purchase whichever cultural, sexual, spiritual, artistic or political experience you desire. You can impersonate other gender or ethnic identities without having to suffer any physical, social, or political repercussions, or be subjected to the rage of the excluded. You don't even need to belong to any 'real' community. And you can do all this from the solitude of your home or by visiting this gallery."

${ }^{87}$ Acertou.

${ }^{88}$ Nome que um paciente me deu.

${ }^{89} \mathrm{O}$ que nos cerca são estacas de madeira com arame.
} 
traduzido seria algo como "pan-uniadade” (SAFRA, 2004). Ainda com Safra (2004, 43-44) temos que "Sobornóst assinala que cada ser humano é a singularização da vida de muitos [...] da vida de seus ancestrais e é o pressentimento daqueles que virão [...] cada ser humano carrega potencialidades de ser". O ser humano em Sobórnost vive em comunidade, que não se restringe apenas ao seu presente ou ao seu passado mais próximo, como pais e avós, esta comunidade se estende ao que não temos acesso conscientemente.

O indivíduo por Sobórnost é in.diví.duo, é um ser que está dentro (in) do outro (duo), sempre com o outro, para os outros de si e do seu meio, vídi bula. Safra (2004. p.50) completa com a ideia de Outro sendo este "O mistério, o contemporâneo, o ancestral, o descendente, a natureza irmã e as coisas mensageiras do Outro", ou seja, o Outro se amplia para uma dimensão de universo subjetiva e afetiva, uma comunidade sem bordas. Um ser humano não tem como ser um, quantitativo, dentro de mim sou diversas e minha maneira de expressão é múltipla, Safra (2004) explica que não me expressar diante de tantas possibilidades de existência me adoece, em coletivo.

Pensando nas diversas experiências no Hospital e no corpo coletivo em Sobórnost percebi que minhas experiências em teatro haviam me servido até certo ponto, porque este lugar outro, expressivo mostrava que eu não poderia fugir de mim. O personagem existe, mas não em meu corpo, neste de agora, ele existe no papel, é literário, está preso na liberdade das palavras, e eu não posso sê-lo, porque meu corpo não cabe em brochura, por mais que eu tente. A ideia de fazer teatro tentando encaixar o corpo do texto no meu corpo expansivo me parece reducionista às tantas possibilidades de criação. Para meu corpo de hoje, assumir/acreditar que sou frases e características ditas em um papel é fugir de mim, mas perceber o texto e como ele chega ao meu corpo de outro/Outro me faz viver este corpo com outra de mim, não sou Julieta ${ }^{90}$ do papel porque Julieta já se faz presente em mim. Jodorowsky, assim, aponta (2009, p.25) "O teatro é uma força mágica, uma experiência pessoal não transmissível. Não pertence aos atores, e sim a todo mundo". Não só o teatro tem este privilégio, o fazer artístico, independente de linguagem desce como raio. O contato de um corpo com o outro faz emergir situações tão novas quanto similares a que este já experienciou, vou descobrindo que para

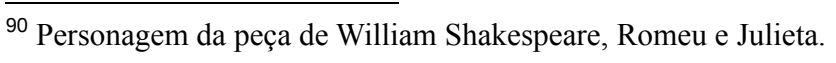


cada caso outra de mim surge para que habite outros de outros.

Se pudesse não gostaria de pensar nos trilhos, queria ser passageira, ser tranquila, estar bem, aceitar o papel que me dão, nas ideias que me querem, se pudesse me faria ser querida, ser boa. O que é um aplauso? Alguém disse que isso era aprovação. Está lindo. Ok, você fez, eu vi. Uhuuu. De pé. Um aplauso de pé, significaria alguém cansado de estar sentado? Casa cheia. São cabeças, peles e corações. A língua na dança das cobras. Quem não faz a cobra subir não pode ser Carla Perez ${ }^{91}$ ? Os aplausos são tapas que uma mão dá na outra. São nos tapas que se indica um fim. É entre os tapas e beijos que é ódio é desejo ${ }^{92}$. É no tapa que está lindo, que foi bom, que foi ruim, para quem? (Authora Desconhecida, 2015)

Após perceber este corpo Hospital, improvisado, espontâneo em mim e o corpo em Sobórnost, outro, Outro, o mundo como meu, se quando faço teatro não sou o personagem e como gosto de nomear ${ }^{93}$ qual seria o meu corpo ao realizar uma peça? ChicQueiro. Um dos termos encontrados é o de persona, a persona é uma máscara que adquirimos para transitar em nosso meio social, é um Eu que se mostra diferente nas diversas situações da vida e nas relações interpessoais, Safra (2004, p. 56) apresenta que "A persona acontece não por seu ser, mas por seu relacionamento social com os outros". Esta persona é o que mais estaria entre o que seria o personagem e o eu/outros, um corpo de artista que ao se apresentar se prepara, alterando o estado de seu corpo para realizar um ato artístico. Carvalhaes (2012, p. 104) nos diz que "A persona é um híbrido: mantém características de cada pessoa, de um e de outro inteiro, ou seja, não é um todo homogêneo. É uma multidão em dinâmica”. A persona, com suas experiências, é amorfa, incompleta e se molda ao seu meio, ela é Sobornóst, cheia de si e dos outros.

O ex-ator, o homem pânico, não atua numa representação e eliminou totalmente o personagem. No evento pânico, este homem pânico tenta alcançar a pessoa que está sendo... O pânico entende que na vida cotidiana todos os 'augustos' andam disfarçados, interpretando um personagem e que a missão do teatro é fazer com que o homem-abandone a interpretação de um personagem diante de outros personagens, que, finalmente, o elimine e vá, aos poucos se aproximando da pessoa. (JODOROWSKY, 2009, p.42)

Porém, para este trabalho a noção de persona se apresenta como um estado, um impulso, não exatamente enquanto máscara subjetiva, mas algo muito mais interno do que exteriorizado. Temos com Peña (2005, p. 25), a respeito do seu processo criativo, que "Meus colaboradores e eu sabemos muito bem que com o uso de próteses, maquiagem, acessórios, e fantasias, nós

\footnotetext{
${ }^{91}$ Ex-dançarina do grupo É o Tcham.

92 Canção Entre Tapas e Beijos. Interpretada por Leandro e Leonardo.

93 Também faço parte do poder de nomear.
} 
podemos reinventar nossa identidade aos olhos dos outros $[\ldots] "$ ". 94 . A identidade performática é uma entidade encarnada, sagrada que deixamos que escorra pelos olhos, pelas secreções, pelo suor, é nosso se mostrar ser no meio/acima/abaixo/de um lado/do outro/na borda/suicídio social/fora do tempo e espaço, em que habitamos.

Quando me apresento assumo um corpo que está energeticamente alterado, que assume uma identidade, que também é minha, e assim uns chamam de personagem, outros persona performática, eu poderia chamar de delírio. Cada um em seu processo criativo encontrará, ou não, métodos que melhor se adequem as suas reais necessidades e assim nomeará para que este estranho possa ser reconhecido e familiar, "Eu sou uma meretriz, mera atriz" ${ }^{95}$. Kantor (2008, p.136) acredita que "O ator não representa nenhum papel, não cria nenhuma personagem, nem a imita, ele permanece antes de tudo ele mesmo, um ator carregado de toda essa fascinante bagagem de suas predisposições e de suas destinações". Neste trabalho interpretar, representar, re-apresentar, atuar, presentificar me envolve da seguinte maneira: quanto mais interpreto mais na escuridão entro, quando represento me sinto representante da Avon $^{96}$, quando re-apresento é a mim no mundo, quando atuo sou atuada em flagrante, quando me presentifico uso lacinho de fita de cetim.

Ao trabalhar com pacientes psiquiátricos percebo, com os meus olhos, uma sinceridade de suas ações e fala. Quando doía, estavam felizes, queriam dançar, este corpo recebia, muitas das vezes, um impulso para o imediatismo, e este corpo do agora tento reencontrar em mim. Kantor (2008, p. 136-137) afirma "Se o atør, por causa de uma decisão interior imperiosa, intervém em tal ou tal momento, é porque sua vez de atuar precisa se manifestar antes de dar a vez a um outro ator". Dentro do Hospital emergia dos pacientes a urgência de realizar, de gritar, de bater, de silenciar, de abraçar e isto assumia em mim, um receio de como trabalhar com as brechas. Jodorowsky $(2009$, p.41) com relação ao lugar do trabalho do ator afirma "E , por fim, pensei que era inútil interpretar um personagem. $\mathrm{O}$ ator, como pensei então, deve tentar interpretar o seu próprio mistério, exteriorizar aquilo que traz dentro de si”. Assim como fazer qualquer trivialidade do cotidiano estar no Hospital me trazia improvisos e imprevistos mais abruptos que hoje abraço e tento relacionar ao meu trabalho e a minha vida, tentando permitir o que me foi silenciado de poder se expressar.

\footnotetext{
94 "My collaborators and i know very well that with the strategic use of props, make-up, accessories, and costumes, we can actually reinvent our identity in the eyes of others [...]"

${ }^{95}$ Trecho da pecinha Pós-Traumática: M\&Mz, From Hell With Love $<3$.

${ }^{96}$ Marca de cosméticos.
} 
Esse corpo, que expulsa sua vontade como larva, supera o drama. A ideia para um Teatro PósTraumático $^{97}$ me empurra contra a parede durante todo este processo de aprendizado com o outro/Outro. Durante o trabalho artístico ${ }^{98}$, relacionado com minhas vivencias no hospital, pesquisei a autora Pankow, que trazia o corpo dissociado como a criação de um corpo póstraumático. Se existe um corpo no pós-trauma poderia existir então uma arte pós-traumática? Ou quem sabe um Teatro Pós-Traumático bem como um que se chama Teatro PósDramático $^{99}$ ? Estou em sua busca. O drama, para os meus olhos, é esse corpo urgente que fala de boca cheia, se entala ou digere, o trauma vomita, o pós-trauma é quando ele come Cream Craker ${ }^{100}$ e precisar falar: "O drama é realidade. Tudo o que se passa no drama é verdadeiro e sério". (KANTOR, 2008, p.4). No pós-trauma, para meu trabalho artístico, o que se diz, muitas vezes, é levado como falso, é um desencontro de informações, um quebracabeça literal, ele não é engraçado, mas aqui falamos de arte, e não é que ela venha a ser irresponsável e oprimir o que já é oprimido, mas existe a possibilidade de ressignificar este corpo $^{101}$.

Por minha vivência em ambiente psiquiátrico percebi que o drama-trauma-pós-trauma existem em instancias diferentes. O drama está vivo em nosso cotidiano, nos acompanha desde as pequenas coisas como uma linha na agulha até casos bem mais graves como ver sua mãe sendo morta pelo seu pai ${ }^{102}$. O corpo no drama é um pensa.dor, ele analisa a situação, articula maneiras de resoluções, sofre por ansiedade, angustia e derivados. O trauma é decorrente do drama. Algo acontece a alguém e isto reverbera em seu corpo a ponto de deixar marcas que não conseguem se resolver sendo carregadas com essa pessoa e marcando suas outras relações. Esse trauma, dependendo do tamanho do drama, pode ser irreversível, medicamentoso, adoecendo o in.diví.duo azul.

O corpo no pós-trauma surge como Estresse Pós-Traumático (TEPT) (DALGALARRONDO, 2008), pode ser considerado um corpo que foi exposto a alguma situação tida como traumática e o ser sente então horror, medo e revive este sentimento em sua rotina. A emoção

\footnotetext{
${ }^{97}$ Termo, hoje em dia, utilizado pela autora Magda Romanska em seu livro The Post-Traumatic Theatre of Grotowski and Kantor: History and Holocaust in 'Akropolis' and 'Dead Class' e pela pesquisadora Katharina Pewny e Karen Jürs-Munby. ${ }^{98}$ Eloucubrações: O Corpo é a Parte do Corpo Todo.

${ }^{99}$ Desenvolvido por Hans-Thies Lehmann. Seu livro não será utilizado nesta pesquisa, por acreditar que ele se apropria do fazer artístico de outros artistas para justificar sua teoria.

${ }^{100}$ Marca de biscoito/bolacha.

${ }^{101}$ Meu corpo também vive a sua doença, não na mesma proporção de outros e na arte não tenho a cura, mas tenho a sua expressão validada, e assim posso dar nomes as minhas dores.

${ }^{102}$ Experiência de um dos pacientes do Hospital Ulysses Pernambucano.
} 
forte que aconteceu pode ser ignorada e pouco acessada pela pessoa, o que não quer dizer que houve o esquecimento. $\mathrm{O}$ corpo sintomático vai sofrendo embotamento, o in.diví.duo sofre desrealização, o estar próximo aquilo que o fez sofrer pode aumentar o TEPT, o que necessariamente não anula o fato da própria pessoa imaginar que o risco não está longe de sua pele.

Uma arte não precisa ser bela, feia, boa, ruim, alegre, triste. Essas classificações acontecem, não há mal em existirem, tudo dependerá dos olhos de quem a faz e a vê, uma arte precisa ser e se relacionar, com respeito a sua expressão. Sou artista e como artista, que teve suas experiências e, hoje assume este corpo meigo e tão pequeno que há uma espécie de veneno bem gostoso de provar ${ }^{103}$, tenho tendências a rir $^{104}$ das coisas e tratá-las como piada de sorriso amarelo. $\mathrm{O}$ meu corpo assim se expressa e resinifica o objeto para a minha prática artística.

Assim o fiz com o TEPT, associei um Teatro Pós-Traumático não como um teatro da cura, mas da expressão de um corpo porco, ChicQueiro, que é a morada do Deus, um corpo antigo, jocoso, que entulha presentes na estante, anjinhos de gesso, meias listradas, usa conjuntinho felpudo para colocar como pano de chão no banheiro e no assento da privada, um corpo que tem uma colcha rosa acolchoada e fronha em formato de coração com babados, que possui flores de plástico na sala e bebe cidra em copo de requeijão.

Um corpo paradoxal, que se mexe sem saber por que, que fala sem entender, que dança fora do ritmo. Uma arte pós-traumática é uma arte, até o momento, que vai, como foguete, sem paradas dramáticas, sem relembrar o que lhe feriu, ela é a pedra no bodoque, ela não faz sentido, porque se fosse para fazer sentido ela estaria no quartel. O corpo neste Pós-Trauma não faz treinamento para ator, mas um Tratamento de Identidade Performática. Brook (2008, p.7) coloca "Mas o veículo do drama é carne e osso". Do trauma são as vísceras, do póstrauma um guisado de frango.

Para a pesquisadora Katharina Pewny, esse lugar, de uma arte Pós-Traumática, se dá na junção da performance arte, teatro, estudos culturais, filosofia e questão de gênero (PEWNY, 2003). Para ela, as questões de trauma podem ser trabalhadas pela arte contemporânea, em especial com o teatro e a performance arte, pois são artes ligadas pelo corpo permitindo ser

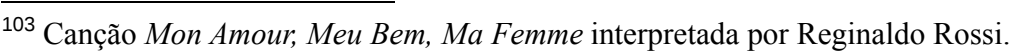

${ }^{104} \mathrm{O}$ riso muitas vezes é tido como algo que não possui seriedade.
} 
catalisadores eficientes de temas sociais. Pewny encontra em sua pesquisa duas vias de sintomas, o sossego (rest) e o desassossego (unrest), sendo as mulheres, vistas na Europa, com um corpo de desassossego, mais propensas aos estresses pós-traumáticos (PEWNY, 2003). Sua pesquisa se dá em encontrar textos teatrais, personagens e performances que possam mostrar o corpo feminino enquanto um lugar do inquieto.

Não venho por meio desta pesquisa excluir/diminuir/menosprezar outras maneiras de fazer teatro. Não existe certo nem errado, a técnica é necessária, a mimese corpórea é necessária, a improvisação é necessária, os ensaios longos são necessários, os conceitos da indumentária, maquiagem, cenografia, iluminação são necessários, o teatro edifício é necessário, o ritual ancestral sagrado é necessário, mas esses métodos para este trabalho, para minhas experiências, para este momento criativo do meu corpo no aqui-agora não cabem na minha nécessaire. O que escrevo é uma tentativa de estruturar uma ideia que ainda não possui corpo $^{105}$, pensando que talvez este "não" corpo pode ser o seu corpo.

\subsection{CARTA PARA ARTAUD}

Brasília, 24 de março de 2015

\section{Bonjour, meu caro companheiro,}

Fiz um breve levantamento do seu material escrito ainda em inconsciência e agradeço imensamente a sua ousadia e fé. Seu coração pulsa em cada página de suas cartas e apelos para que te levem a sério. Hoje você é muito bem lembrado. Imagino como foi duro para você ter que falar com paredes durante tanto tempo, apesar de que eu também já tive a honra em tê-las como aliadas até me suprimir. Mas é como você mesmo diz "¿Pero qué me importa toda la Revolución del mundo si sé permanecer eternamente doloroso y miserable en el interior de mi propio osario?" (ARTAUD, 1999, p.5).

Artaud, diziam que sua ossada estava podre. Me disseram que sua saúde era uma boneca de porcelana, que deve ter caído da estante quando ainda criança. "Cuando no se hace nada no se

\footnotetext{
${ }^{105} \mathrm{Me}$ justifico tantas vezes durante a dissertação, pois tento não fazer com outras pessoas o que fizeram comigo. Privaram minha liberdade artística, de gozar e de ser. Cada um trepa como gosta.
} 
corre el riesgo de romperse la cara." (ARTAUD, 1999, p.7). Como você suportou a morte da sua irmãzinha? Aqueles problemas neurológicos? A meningite? Um pai extremamente autoritário? (isso também faz parte da doença) e depois convulsões e uma (lembre-se primeira) internação em hospício aos 19 anos? Como você fugiu das suas dores? Foi o peiote? ${ }^{106}$

Não dá para fugir da sombra, meu querido... Mas ainda bem que seu tio produtor de teatro e o seu psiquiatra, o Dr. Toulouse, te impulsionaram a ir para Paris. De lá você pôde vomitar o que não te caía bem, como ator você trocou o láudano ${ }^{107}$ pela bebida de Dionísio, rasgou os papéis, formulou outras vidas, fez mais por muitos, por mim. Tua breve vivência simbolista até abraçar carinhosamente o surrealismo e levá-lo até Morfeu ao som de harpas. Meu querido, sabemos das nossas escolhas especialmente em seu posicionamento em não querer ver o movimento surrealista se esbofeteando pela política e tomando posição do $P C^{108}$. "Lo que me separa de los surrealistas es que aman tanto la vida como yo la desprecio". (ARTAUD, 1999, p.7). Não precisava brigar com tanta gente por causa disso, a vida é muito maior. E eu acho meu otimismo tão pobre.

\begin{abstract}
El surrealismo siempre ha sido para mí una nueva forma de magia. La imaginación, el sueño, toda esta intensa liberación del inconsciente que tiene por finalidad hacer aflorar a la superficie del alma lo que habitualmente tiene escondido, debe necesariamente introducir profundas transformaciones en la escala de las apariencias, en el valor de significación y en el simbolismo de lo creado. Lo concreto cambia completamente de vestido, de corteza, no se aplica más a los mismos gestos mentales. El más allá, lo invisible rechaza la realidad. El mundo ya no se sostiene. (ARTAUD, 1999, p.9)
\end{abstract}

As coisas não acontecem sem ter um por que. Os mistérios da vida em seu campo místico, subjetivo, que dança por nosso corpo, sai nos rodopios de nossa respiração, nos levitam ao que devemos encarar "Se não tivéssemos fé em um milagre possível, não nos empenharíamos nesta vida cheia de imprevistos". (ARTAUD, 2008, p.35). "Longe" do movimento surrealista os seus achados e perdidos com o Théatre de Alfred Jarry. "Vivir no es otra cosa que arder en preguntas. No concibo la obra al margen de la vida". (ARTAUD, 2002, p.3). Eu sei que a experiência com o seu teatro não deu muito certo, mas foi exatamente pelo experienciar afetivo que você disponibilizava a sua criação estética.

A obra está na vida porque é da vida que surge as entranhas. A vida compõe e se decompõe pelos ralos rasos "Protesto contra a ideia separada que se faz da cultura, como se de um

\footnotetext{
${ }^{106}$ Encontro de Artaud com tribo indígena mexicana Taraumaras. Onde fez o ritual de peiote. Artaud (1985, p. 4).

${ }^{107}$ Extrato de ópio de efeito sedativo. Antigamente usado como remédico.

${ }^{108}$ Partido Comunista.
} 
lado estivesse a cultura e do outro a vida; e como se a verdadeira cultura não fosse um meio refinado de compreender e de exercer a vida". (ARTAUD, 1999, p.7). Mas Artaud, não acredito nessas coisas de certo e errado, de verdadeiro e falso e de pureza que você tanto falava nas suas cartas. Não quero fazer um teatro puro. Somos Deuses, não da pureza cristã, mas deidades, divindades, a Luna Tríplice. Não sou pura, não quero ser e não quero que me limpem. Você também Artaud! A consciência pode expandir ao sagrado, mas o que queremos é o contágio.

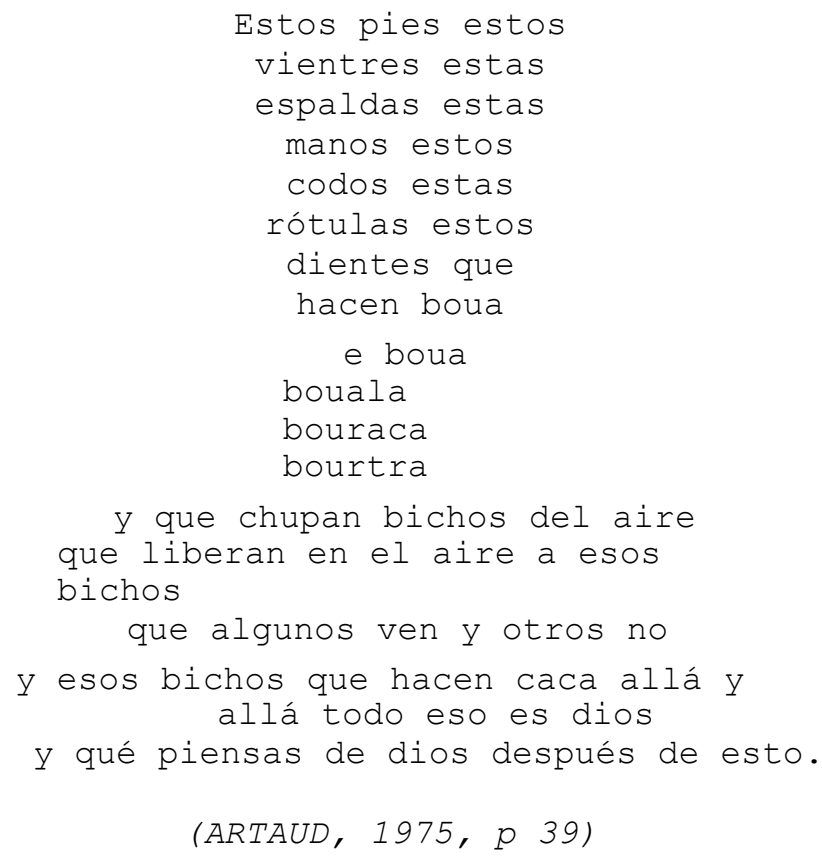

Esse seu teatro é verdadeiro para seu corpo, é puro para sua ânsia. Você é um poeta e te compreendo quando toca na necessidade de reteatralizar o teatro, do grito que urge ao que nos fede por dentro. Apesar de ser outro lugar teatral, o que você faz não quer dizer que seja feito de qualquer jeito, apesar disso não me incomodar. Você calcula a sua produção estética, é exigente, mesmo não se importando em ter atores experimentes, pois o que vale mesmo para você é "uma espécie de sinceridade vital, mais forte do que suas convicções" (ARTAUD, 2008, p.100). Só cuidado com o jeito que você fala. É perigoso, não são todos que estão tranquilos com seu posicionamento. Nos ouvidos dos mais conservadores você dá um eletrochoque na assepsia teatral.

Ainda te dói a cabeça? Porque me machuca saber que já são quase dez anos dentro de um manicômio. Prevejo que você vai morrer aí dentro, junto com os outros pacientes, misturando a sua merda com seu hálito. Não é assim que cheira um hospital psiquiátrico? Vai me dizer que, onde você está, passam amaciante nos lençóis de cama! Por onde ando não passa nem 
gente, só vulto. Como foi tomar eletrochoque? Já publicaram os livros que você escreveu aí dentro? Está conseguindo dar suas entrevistas? Ou essas pessoinhas desse meio artístico ainda te têm como um... Como que elas te chamam mesmo? Ah, retardado mental? Lembro de quando você disse "La medicina pervertida miente cada vez que muestra un enfermo curado por lãs introversiones eléctricas de su método, yo solo he visto a los aterrorizados del sistema, imposibilitados de reencontrar su yo." (ARTAUD, 1976, p.25). Mas sinto te dizer Artaud, que ninguém quer te ouvir. Se quisessem tinham te dado voz, não prisão. Me desculpe.

\begin{abstract}
El origen de la medicina es el mal, si es que no ha originado de la enfermedad, y si, al contrario, ha causado y creado toda la enfermedad para procurarse una razón de ser; pero la psiquiatria ha tenido como origen la turba plebeya de los seres que han querido preservar el mal en la fuente de la enfermedad, y que han extirpado así de su propia nada una especie de guardia suizo para arrancar de raíz el impulso de rebelión reivindicatoria que está en el gérmen de todo genio. Hay en el alienado un genio incomprendido que resgaurda en sua mente una idéia que causa pavor, y que sólo el delirio le permite encontrar una salida a las opresiones que la vida le depara. (ARTAUD, 1971, p. 13-14)
\end{abstract}

Cheri, assim como você nos pede para olhar o teatro a partir do seu espaço e não do texto que nos dão, te falo o mesmo. Olhe onde você está e perceba esta sociedade. Você foi inventado. Seus dentes amarelos de nada valem. Aqui queimamos os bruxos, especialmente na arte! Tão subjetiva, tão criativa, tão cheia de mimmimmim. "Se falta enxofre a nossa vida, ou seja, se lhe falta uma magia constante, é porque nos apraz contemplar nossos atos e nos perder em considerações sobre as formas sonhadas de nossos atos, em vez de sermos impulsionados por eles". (ARTAUD, 1999, p.3). Recuo. Mas é que às vezes, na maioria delas, ser, cansa.

Artaud, perdoa-lhes, porque não sabem o que fazem. Por onde você anda de verdade? Às vezes sinto que te encontro nos rostos das ruas, na cara da medicina, no palco à italiana. Eu tenho você, Artaud, dentro de mim. Desculpe, mas não quero te deixar sair. Tenho medo e você sabe "Por mais que exijamos a magia, porém, no fundo temos medo de uma vida que se desenvolvesse inteiramente sob o signo da verdadeira magia”. (ARTAUD, 1999, p.3). Medo de você sair com seu cajado, me levar e não mais me trazer de volta. Não é que eu não goste de viagens, meu amigo, mas cansei de viajar só e por mais que você esteja comigo, você não é muito de falar. Sinto muito, mas não quero voltar para as paredes.

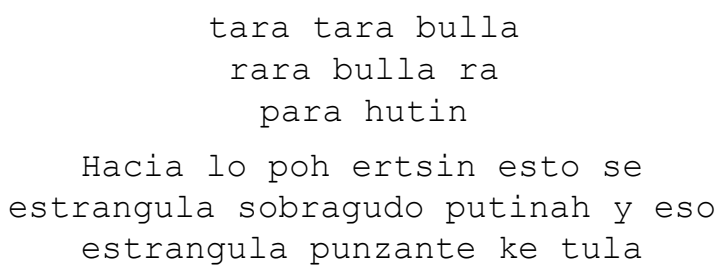




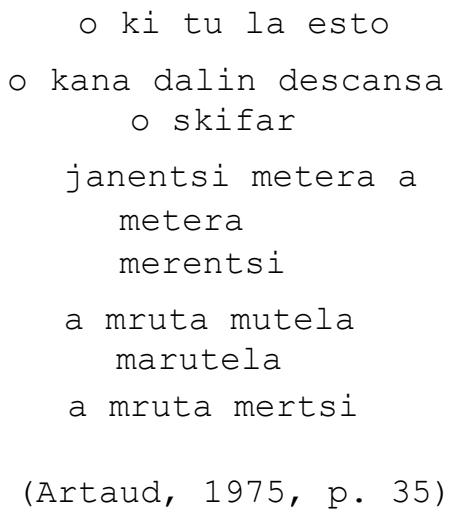

Volto a falar com você outro dia.

\subsection{O PROCESSO CRIATIVO DO CHICQUEIRO}

O Corpo Porco rouba sorvete napolitano quando ninguém vê, faz montinhos e come seu feijão e arroz com as mãos, vê um balde com água e se joga de cabeça achando ser uma piscina. É do nosso corpo criar imagens a partir do cuspe, reinventar nossos dias de maneira criativa e nos envolver em situações de se engasgar e rir da piada que somos.

O ser humano é o único que pode rir na consciência do riso, que possui o dedo opositor e a capacidade de utilizar a criatividade para reorganizar a sua vida e fazer arte. Safra (2004, p.59) propõe que "A pessoa humana seria, a meu ver, não uma substância ou conjunto de traços, mas um ato, um ato criativo!" Somos aqueles que representam a festividade de nossos corpos e apresentam este aglomerado de memórias afetivas afetadas para o mundo.

\footnotetext{
A característica da criação é o estado fluido, mutante, não durável, efêmero - como a vida em si mesma. É preciso reconhecer como criação tudo o que ainda não virou o que se chama de obra de arte, o que ainda não foi imobilizado, o que contém diretamente as impulsões da vida, o que ainda não está 'pronto' 'organizado' 'realizado': as anotações dos problemas urgentes, das ideias, das descobertas, os planos, os projetos, as concepções, as partituras, os materiais, as ações colaterais. (KANTOR, 2008, p.105-106)
}

Por entre as brechas, a vida quando pintada com as nossas possibilidades de cores, se transforma aos nossos olhos. O efêmero enfermo nos mostra grandes lacunas vazias que preenchemos com imprevistos, acidentes de percurso, com encontros inevitáveis a um poço sem fundo, o que para nós em momento criativo chamamos de nada, pode ser para este 
momento uma pausa para ampliar nossa percepção de mundo antes de fechar uma ideia e dela partir para o que precisa concretizar. Safra (2004, p.27), então, nos fala que "A técnica assim compreendida, joga o paciente em direção ao conceituável, roubando-lhe o indizível e os mistérios de seu ser. Este é o homem-coisa e não mais ser, não mais presença”. Quando a técnica amarra um corpo extra-vagante mal sabe ela que esta dando um tiro no próprio pé, porque a técnica também é humana, canibal, e um dia adoecerá como qualquer um.

A técnica existe e se torna necessária para colocar em prática algumas de nossas necessidades, porém, muitas das vezes, nos atemos apenas a ela, acreditando que por saber manusear os instrumentos, o que está sendo proposto será bem executado, quando na verdade o ser humano não é só técnico, pois se não for por um relampejo intempestivo de nosso eu, não dá para mergulhar no mar e se perder. Safra (2004, p.81) escreve "A criatividade humana, por ser ação no mundo e para além do mundo, faz com que o ser humano seja sempre um ser fronteiriço, em estado de precariedade originária, em que qualquer ação seja sempre uma transição". A cabeça acredita que limpa o que o emocional bagunça.

Esta vida que nós pretendemos lógica é, na realidade, louca, chocante, maravilhosa e cruel. Nosso comportamento, que pensamos ser lógico e consciente é, de fato, irracional, louco, contraditório. Se observarmos lucidamente nossa realidade, constataremos que é poética, ilógica, exuberante. (JODOROWSKY, 2009, p.36)

Nossos sentimentos não são à prova de balas e adoram quando recebem um Banzé sabor menta, Sonho de Valsa e derivados. Mexer em nosso emocional é como vasculhar as milhares tupperwares que perdemos, na esperança não só de recebe-las de volta, mas do dia em que vamos precisar delas, como naquele aniversário que você leva um pedacinho de bolo para casa, no almoço tumultuado com jogo de futebol e galinha assada nos dedos. A lembrança nos faz perceber que desde pequenos aprendemos que emprestar tupperwares é um ato de amor. Emoticon Heart.

O brega está dentro das nossas casas, mas não qualquer casa, digo isto com olhos estrangeiros, pois só tive uma casa e foi a da classe média. Essa classe mediana que fala de boca cheia, que tenta frear seu instinto selvagem e se portar bem nas fotos, na frente das visitas ou quando fazem aparições públicas em shoppings, como Brook (2008, p.77) expressa “Um público popular é muito mais vivo em suas reações do que um de classe média”. O brega antes de ser brega era o cafona, vinha nas músicas românticas representadas por cantores que faziam sucesso nas camadas mais populares, o brega foi coroado, com coroa de strass, na 
década de 80 e após uma montanha russa de aceitação e esquecimento na década de 90 se misturou à lambada e forró e no inicio dos anos 2000, como afirma Fontanella (2005) o movimento voltou com força estando até os dias de hoje envolvendo não só as lembranças dos mais "antigos", como as festinhas cult dos jovens.

O público popular passa na feira, compra o que quer e vai embora, que nem criança, são sinceros com suas necessidades e urgências. Percebo o artista de rua fazendo parte desta arte camelô. Ele parece aceitar o que lhe dão sabendo que a rua é livre para ir e vir, ele é como um louco que delira a céu aberto, só que paramentado. Brook (2008), assim coloca sua prática artística e chama seu teatro de barraca de feira e o de ambulante. Uma arte sucata, sucateada, souvenir do espetáculo, jarra de abacaxi com suco de laranja e pinguim em cima da geladeira. Safra (2004, p.45) coloca que "A cultura liberta a pessoa da sociedade na qual ela vive". As diversas maneiras de expressão nos auxiliam a ir de encontro a nossa identidade e a nos construir enquanto seres, a cultura também faz parte do social e nem ela está liberta, como Brook (2008, p. 26) expõe “... falam da peça domesticada onde 'mais elevado' só significa 'mais bonitinho' - ser nobre só significa ser decente - enfim, finais felizes e otimismo não podem ser encomendas como vinho de adegas". O brega vem embalado com papel de presente, com laço de fitilho de plástico colorido, com um adesivo escrito "De" "Para". O brega se instala em nossa memória, é uma festividade das nossas recordações, o brega é um vintage de quem aprecia Katuaba ou Carreteiro ${ }^{109}$.

O grotesco ${ }^{110}$, o bizarro, o trash, o nonsense $e^{111}$, o kitsch $^{112}$, o mau gosto ${ }^{113}$, o erro, o feio ${ }^{114}$, o brega $^{115}$, o cafona, o delírio ${ }^{116}$ são crias que ainda não assimilamos enquanto parte, não só de nosso corpo, mas como algo a ser compartilhado nas artes. Percebemos o morador de rua, o louco que vaga sem rumo, a prostituta que não é de luxo, a viciada em crack, a lixeira cheia de mosquitos, o alto do morro com luzes, o suor nos transportes coletivos, limpar a bunda e aquela massa feder, vomitar nosso almoço e vir com caroço de feijão. Em Bakhtin (2010, p. 26) temos o corpo do grotesco como "É um corpo que não tem lugar dentro da 'estética do belo’ forjada na época moderna". Não é porque tomamos banho que nosso corpo se distancia

\footnotetext{
${ }^{109}$ Marca de vinho barato.

${ }^{110}$ Para os dias atuais, o bufão transformou o grotesco em um viés de expressão artística, que hoje é aceito e contemplado.

${ }^{111} \mathrm{O}$ autor Lewis Carroll com o livro Alice no País das Maravilhas, colocou o nonsense em prateleiras agradáveis.

$112 \mathrm{O}$ diretor espanhol Pedro Almodóvar auxiliou a elevar o Kitsch ao cult.

${ }^{113}$ A banda de axé É $O$ Tcham era tida como mau gosto, hoje em dia é um artigo vintage.

${ }^{114} \mathrm{O}$ Patinho, que era Feio por ser diferente, é uma história infantil.

${ }^{115} \mathrm{O}$ brega, hoje em dia, é abraçado e acolhido debaixo de garrafas de cerveja Budweiser e Heineken.

${ }^{116}$ Este continua dentro das casas com receio de sair ou em festas com uso de drogas alucinógenas, porque é um barato.
} 
daquilo que negamos fazer parte, nossa assepsia parece querer ser clínica patológica, mas ela é cínica. Bakhtin (2010, p. 33) "O sublime sobre o sublime dificilmente produz um contraste, e tem-se necessidade de descansar de tudo, até do belo".

O grotesco possui um corpo que foge às regras normativas, ele se expressa pela caricatura, pelo extravasamento, expõe seu baixo corporal, tudo aquilo que é de mais humano e não se associa ao espiritual, como comida, bebida, sexo e prazer (NASCIMENTO, 2006). Este corpo grotesco, que pode ser azul ou o que quiser, é por Bakhtin $(2010$, p.77) “... um corpo em movimento. Ele jamais está pronto nem acabado: está sempre em estado de construção, de criação, e ele mesmo constrói outro corpo; além disso, esse corpo absorve o mundo e este é absorvido por ele". O grotesco aparece como um transbordar do social, ele aponta com seu sexo o escarnio que outros viram a face, tornando o realismo em algo fantástico, podendo ser tão extremista que é considerado monstruoso (BAKTHIN, 2010). Ainda com Bakhtin (2010, p.4) temos que “... a função do grotesco é liberar o homem das formas de necessidade inumana em que se baseiam as ideias dominantes sobre o mundo". O grotesco é como um corpo carnavalizado fora do contexto dos grandes blocos de rua, é aquele pontinho estranho que expõe o privado ao público nos relembrando de onde viemos.

\footnotetext{
... A criação do grotesco pode surgir na visão de quem sonha, de quem devaneia, de quem exprime uma visão desencantada da existência, assimilando-a como um jogo de máscaras ou uma representação caricatural. Desta maneira, pode assumir formas fantásticas, horroríficas, satíricas ou simplesmente absurdas. (SODRÉ E PAIVA, 2002 apud NASCIMENTO 2006, p.1)
}

Uma das maneiras de se encontrar com o grotesco é por via do nonsense, tantas vezes utilizado na literatura e em filmes, o nonsense articula o que não faz sentido, contrariando o que seria da ordem e o fluxo comum das coisas, alterando a realidade de forma fantasiosa e muitas vezes onírica. O nonsense, por ser considerado uma arte da brincadeira (BASTOS, 1996), é tido como arte insignificante “Além disso, também muitas vezes esse tipo de poesia é encarado como sendo apenas nonsense, uma coisa menor. O rompimento com a ordem lógica, ordem que conhecemos, o surgimento de uma outra ordem, o rompimento com a expectativa [...]". A prática do nonsense dança com a nossa consciência, o que antes poderia estar reprimido. Muitos podem achar que a arte contemporânea pisa com os dois pés no nonsense, por esta trabalhar elementos que não são habituais ao cotidiano, ressignificando nossas relações com o fazer artístico e alterando nossos pontos de vista com a relação de mundo. 
uma maneira alegre, nos diz algo de nossa infelicidade diante da ordem costumeira. Por várias vezes, com sua aparência cômica, mexe com as coisas sérias de nossas vidas - desejo e morte, identidade e autoridade, linguagem e significado, divertimento e jogos. E ainda é inerentemente um protesto contra a tirania de uma ortodoxia séria. (BASTOS, 1996, 42)

O jogo do nonsense se mostra em criar uma sociedade que dá vida as pulsões mais primitivas, aos desejos mais secretos, aquilo que em sonho poderia ser efetuado, o nonsense faz se tornar realidade enquanto olhos abertos. Geralmente quem se porta desta maneira em nosso meio social são as crianças, que sofrem uma ação e no impulso devolvem com uma reação, Thomaz (2013, p.56) assim explica "Não há espaço para o didatismo no nonsense. Ele se funda no espaço da imaginação e do absurdo, da desobediência e da desconstrução. [...] impõe uma lógica do avesso, que lembra o pensamento infantil". O nonsense não necessariamente constrói figuras como o grotesco, que muito trabalha com o baixo corporal e deformações deste corpo, o nonsense pode trazer pessoas cotidianas em histórias mirabolantes utilizando da sua "lógica", com Bastos (1996, p.39) temos que "Uma negação remete a uma afirmação e é assim que o nonsense prova a existência do sentido: paradoxalmente. O nonsense remete ao sentido. Na medida em que o nega, afirma-o". No nonsense o sentido não é dissociado do corpo, o sentido é o impulso para a ação, já no grotesco o desejo impulsiona o corpo para agir e assim gerar sentido.

Cada forma de expressão ri da piada que somos à sua maneira. O brega gargalha. $\mathrm{O}$ grotesco mostra sua boca sem dentes. O nonsense ri amarelo. O riso é um risco em meio a nossa face que quando desmorona vira um buraco sem fundo. O riso é um escorregar ao desconhecido, é particular, explode em sonoridades, é tão falso quanto uma nota de doze reais e tão verdadeiro quanto os nossos desejos mais submissos. Bakhtin (2010, p.34) afirma "O riso foi enviado a terra pelo diabo, apareceu aos homens com a máscara da alegria e eles a acolheram com agrado. No entanto, mais tarde, o riso tira a máscara de alegre e começa a refletir sobre o mundo e os homens com a crueldade sátira". É pela boca que entra e sai o gozo, nosso alimento diário, é pela língua que nos sufocamos pelas palavras não ditas e arremessamos o outro de nós contra a parede.

A comédia pode ser como uma colmeia que mesmo bela por sua natureza possui um tumulto interno. A arte pode não conseguir fugir das suas contradições e não seria o ser humano que iria ter pernas para fugir de si, aceitar este corpo que joga água no barro e faz lama seria uma possível forma de dar passagem ao que para nós é irracional. Kantor (2008, p.92) coloca "Se 
com isso admitirmos que a arte não é uma expressão e nesse caso uma expressão de estados 'máximos', aceitaremos facilmente os estados e as manifestações tais como: aversão, apatia, perda de vontade, tédio, monotonia, banalidade, ridículo, indiferença, estado vegetativo, vazio...". O ChicQueiro ${ }^{117}$, Ele está no meio de nós, enquanto Patos/patetas, viver fora do ChicQueiro não nos garante uma vida longe dos nossos incômodos. Kalil (2013) em entrevista releva que: "O que faz uma pessoa chique, não é o que essa pessoa tem, mas a forma como ela se comporta perante a vida". Podemos mudar de casa, mas não mudamos de sombra. A dificuldade em não prender o corpo no virtuosismo dos livros ou dos grandes mestres, porém também não os deixar soltos no labirinto de Ariadne, é como driblar o 7x1 da Brasil com a Alemanha ${ }^{118}$, mesmo que difícil, ainda assim se permitiu jogar.

\subsection{APRESENTAÇÃO: M\&MZ, FROM HELL WITH LOVE <3}

Para falar de Merteuil e Valmont, Heiner Müller e Heiner Mulher, Merthelinny y Merthiolat escuto Chris Isaak, Garbage, Santana, Santa Esmeralda, Placebo, Kansas e qualquer coisa que embale meus quadris ou meu olhar turvo. Encontro Quarteto ainda em época de graduação para uma das disciplinas do curso. A poesia de Müller, foi dançada por Bob Dylan ${ }^{119}$, suas palavras apertavam a espinha que eu guardava entre os seios, Merteuil com nossa raiva, nossas dores, se encontraram. Eu era ela tanto quanto ela era eu. Foi vestida de vermelho, com anel de strass, colar de pérolas falsas, boca carnuda e meus passos em falso que, pela primeira vez, falamos juntas.

Em outro momento da graduação Merteuil voltou a bater na minha porta, refizemos os nossos interesses e concordamos em brincar novamente juntas. Joguei ao chão um tapete de páginas de revistas com homens e mulheres pelados. Valmont, apenas um brinquedo de suas vontades, era meu querido ursinho de pelúcia da minha infância, o Pimpão. Fizemos nevar com isopor, tomamos, cenicamente, remédico em gotas em uma taça azul kitsch, demos grandes espaços às cenas e criamos um chafariz de cupido que jorrava vinho.

Quarteto é uma peça de Müller Mulher, que convida Madame de Merteuil e o seu amante de

\footnotetext{
${ }^{117}$ O ChicQueiro para este trabalho é o brega, o cafona, o corpo festivo das cores e brilho.

${ }^{118}$ Copa do Mundo, 08/06/2014.

${ }^{119}$ Música Beyond Here Lies Nothing.
} 
relações, o Visconde de Valmont a se amar(rar)em em um bunker francês antes da Revolução Francesa e após a Terceira Guerra Mundial. Todo o texto de Müller Mulher é discorrido entre salivas e uivos de uma França pomposa e decadente, com uma linguagem ácida, animalesca. Quarteto enche de facas os bons costumes, a ética, a moral, a mulher e a religião, temas que continuam atuais. Enquanto seres entediados, Merteuil e Valmont, manobram as demais pessoas de seu convívio, por via de jogos sexuais, relações culposas de corpos em putrefação, onde se morre pela língua, pelas relações humanas de um corpo não domesticado, pelos instintos e pela morbidez consciente.

Quarteto trás um corpo doente de mágoas, de falsas intenções, o Corpo Porco da peça contamina com vômitos o ChicQueiro de Patos, patinhos feios e patetas. Müller Mulher escreveu a peça em adaptação ao livro Relações Perigosas de Chordelos de Laclos, escrito em 1782. Laclos, escreveu seu livro em formato de cartas, retratando as relações de futilidade, vaidade, abuso de poder, manipulação social e violência sexual realizado entre homem e mulher. Müller Mulher, com seu Quarteto, satiriza a relação de teatro e público, vida vs. espetacularização, teatro dentro do teatro. Merteuil e Valmont são provocadores de um meio social que trata pudicamente seu corpo e suas interações com o mesmo. Eles não fogem de si e nem de seus desejos, são sátiros da vida privada, gozadores de suas próprias dores.

\begin{abstract}
Que pai? Me deixe ser seu padre, quem é mais pai do que o padre que abre as portas do paraíso para todos os filhos de Deus? [...] Não tema por sua inocência. A casa de Deus tem muitos cômodos. Você só precisa abrir estes lábios assustados, e a pomba do Senhor voará e brotará no Espírito Santo. [...] O que você chama de inocência é uma blasfêmia. Ele só tem amor por uma virgem, o mundo pode lhe dar com apenas uma salvadora. Você realmente acha que esse corpo foi dado a você, para andar sozinha na escola, escondida dos olhos do mundo? Não é bom que um ser humano fique sozinho. Se você quiser saber onde mora Deus, confie no tremor das suas coxas, na fraqueza do seu joelho. (MÜLLER, 1980, p.8)
\end{abstract}

Iniciamos os ensaios para o tratamento da Identidade Performática no mês de agosto de 2015, utilizando uma das salas disponíveis da Universidade de Brasília, como mostra a Fig. 18. A princípio, o processo de realizar a pecinha de teatrinho foi muito doloroso para mim, devido às diversas tentativas em fazer teatro e a sua maioria fracassar. Precisei fazer um tratamento intenso de acupuntura e óleos essenciais, acompanhado do Tarô das Deusas, Baralho Cigano e muita macumba para poder firmar no propósito de trabalhar com a

\footnotetext{
120 "Why father? Let me be your priest, who is more of a father than the priest who opens the door to paradise for all the children of God? [...]Do not fear for your innocence. The mansion of God has many dwellings. You only need to open these astounding lips, and the dove of the Lord will fly out and pour forth the Holy Spirit. [...] What you call your innocence is a blasphemy. He loves only one virgin, the world can do with one savior. Do you think that this eager body has been given to you, so that you can walk alone in school, hidden from the eyes of the world? It is not good for human beings to be alone. If you want to know where God dwells, trust the trembling of your thighs, the weakness of your knees."
} 
pecinha. As nossas sessões terapêuticas pós-traumática aconteciam sem supervisão de um Pato, duas vezes por semana durante 3 horas cada. A meratriz Brennda Gabrielly aceitou fazer parte do Processo do Chicqueiro, mesmo relatando no prontuário que após o processo de recuperação ela ainda não entendia o que estava fazendo.

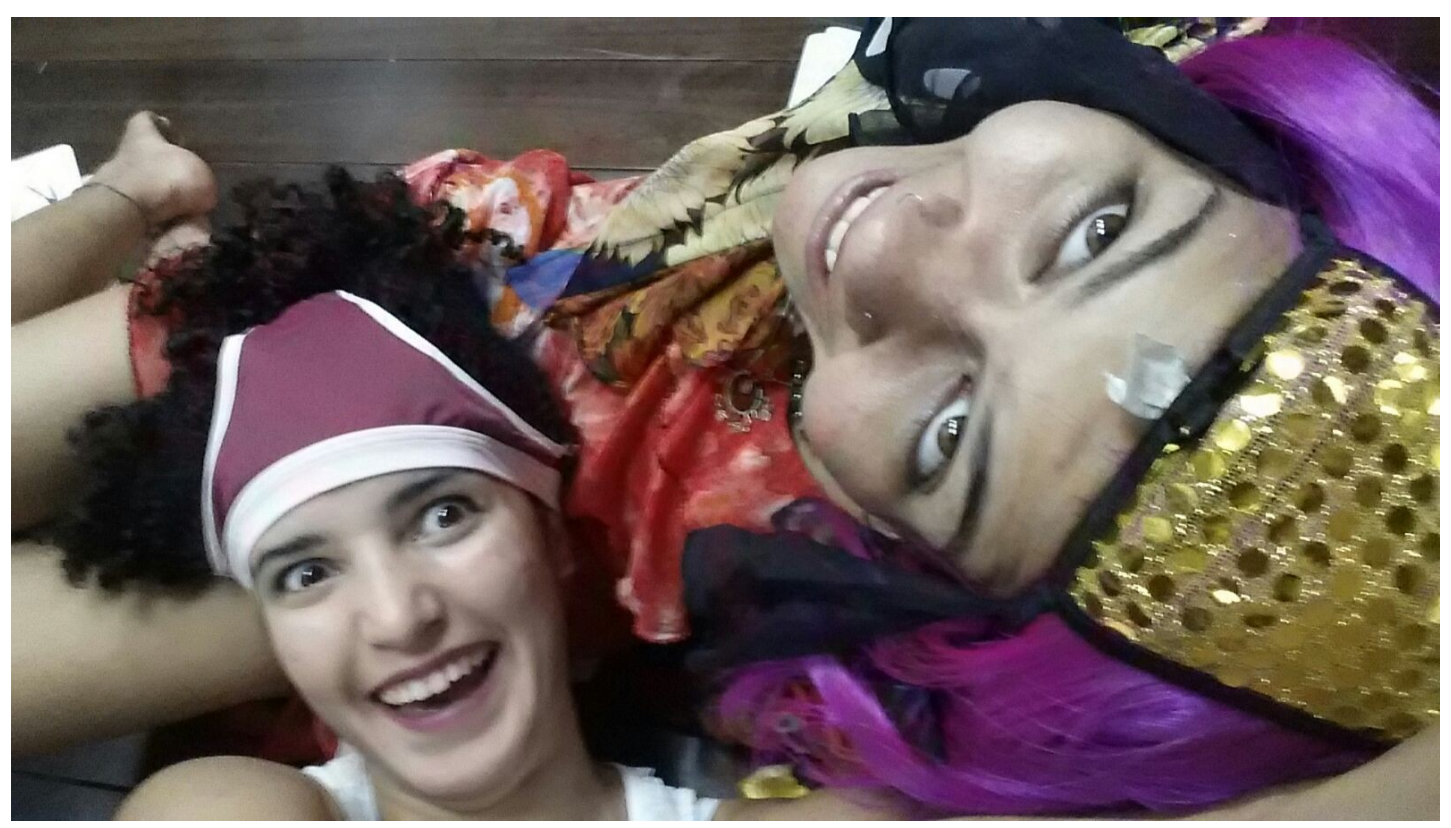

Fig. 18 - Tratamento Pós-Traumático.

Nos ensaios, a princípio fiquei um mês e meio sozinha, devido à impossibilidade de Gabrielly ir. Levei referências próximas a mim enquanto sugestões para estímulos, como uma saia de chita em modelo espanhol, músicas ciganas Balcãs, minhas castanholas, a imagem da Santa Muerte em um altar improvisado com um tecido de tigre... Ficava na sala observando o espaço, me sentindo perdida no mar de possibilidades criativa, tentando disponibilizar meu corpo, me esquivar do meu racional por via de brincadeiras, mesmo que isso se mostrasse angustiante. Tentar achar, sozinha, um brinco na areia do mar me custava o gosto salgado da água. Não gosto de estar só, não pela solidão em si, mas porque já brinquei sozinha muitas vezes e sempre me era árduo.

Brasília, 10 de setembro de 2015 - 00:23

Artaud, como você está? Ando cheia das coisas, queria dizer interrogações, mas não acho que seja isso... Me sinto pisando em reticências, como se elas fossem se quebrar e afundar. Me falaram esses dias sobre paixão, que eu precisava fazer meu coração vibrar, me apaixonar por alguma coisa... A Maria até falou nisso também e foi quando me bateu tão forte, na cara, no chão, debaixo do chuveiro com Reginaldo Rossi. Faz tempo que não vibro, não que seja ruim, mas agora que percebi... Não gostei. Comecei os ensaios Artaud, estou tentando criar vergonha na cara e fazer algo por mim ou pelo o que me move. Foram cinco anos sem estar na sua companhia, foi tudo tão doído e cheio de buracos, estou pisando no contra fluxo. Meus olhos ainda não brilharam naquela 
sala branca, meu corpo não reconhece este lugar de envolvimento, mas algo está acontecendo. Duas vezes por semana algo acontece, estou no horário em ponto onde devo estar e saio em ponto na hora de entregar a sala. Lá dentro o que eu quiser é meu, inclusive essa água que escorre entre as mãos. Artaud, quero te ter por perto, quando você puder vem me visitar. Um grande abraço. (Authora Desconhecida)

Durante os ensaios, enquanto estive só, não consegui tirar muitas coisas, apenas em um dia, que dancei música cigana e senti um fogo subindo pelos meus pés envolvendo meu corpo para algo que queria sair. Andei em círculos pela sala, joguei bulas de remédicos por cima de mim, me sentei em frente ao espelho, peguei um batom vermelho e passei em minha boca. $\mathrm{O}$ batom depois foi espalhado para partes de meu corpo e face, miados, tosse, batom em todo rosto criando uma máscara, me olhei e surgiu vontade de chorar. Palavras apareceram e eu deixei que tudo escorregasse pelo tobogã. Todo o rosto era boca, buraco negro, chakra básico e Valmont que não me ouvia (Fig. 19).

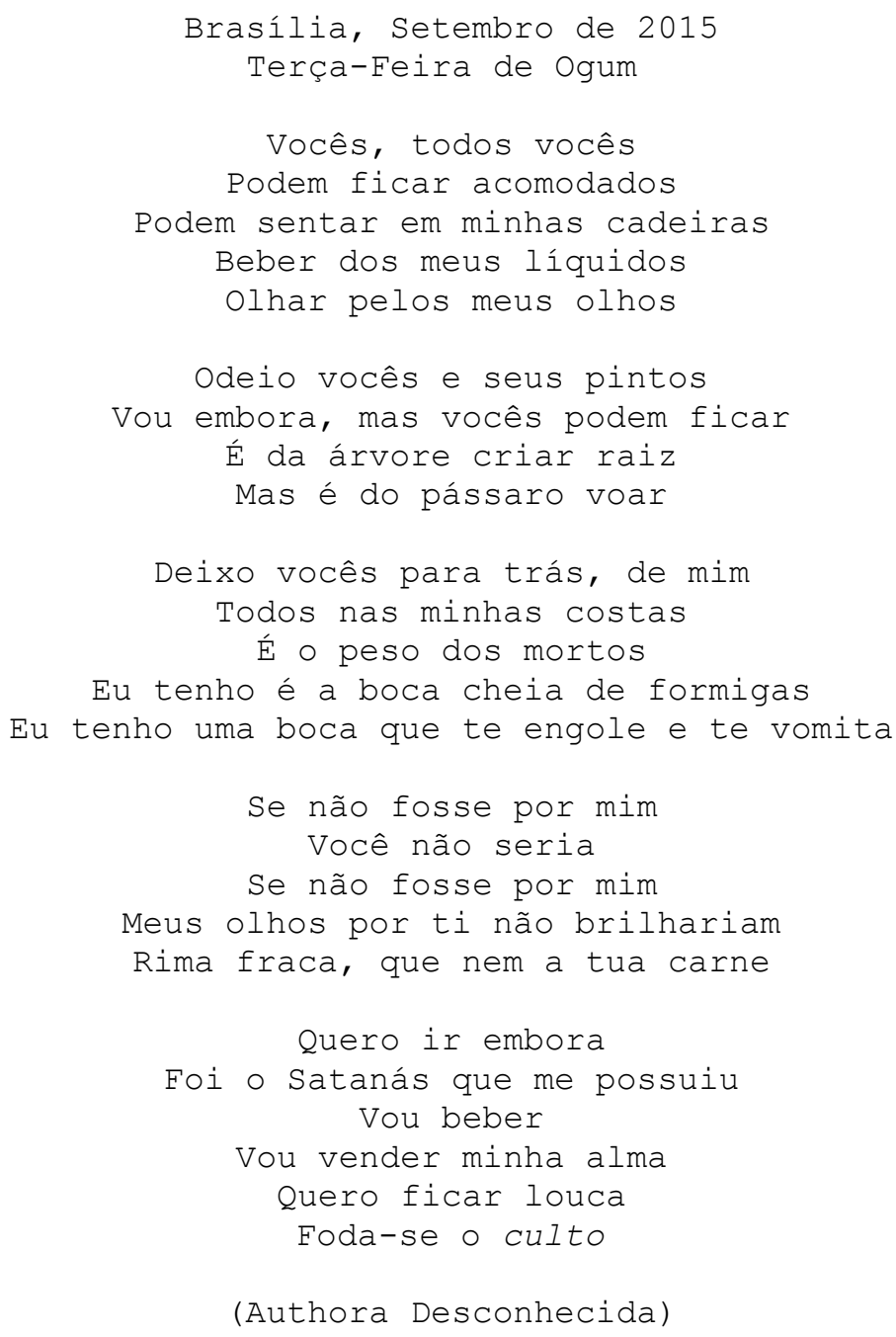




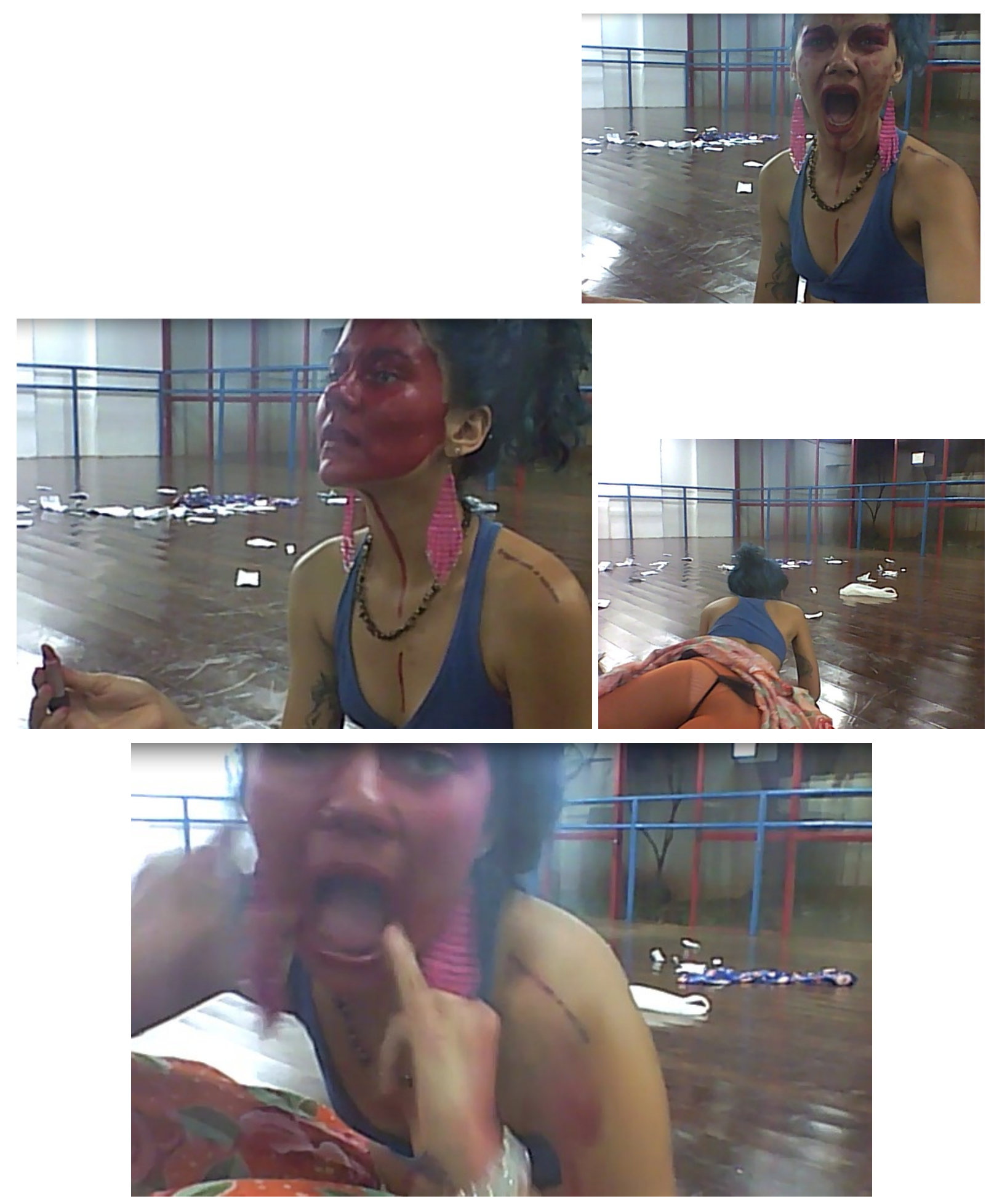

Fig. 19 - Tô borrada? 



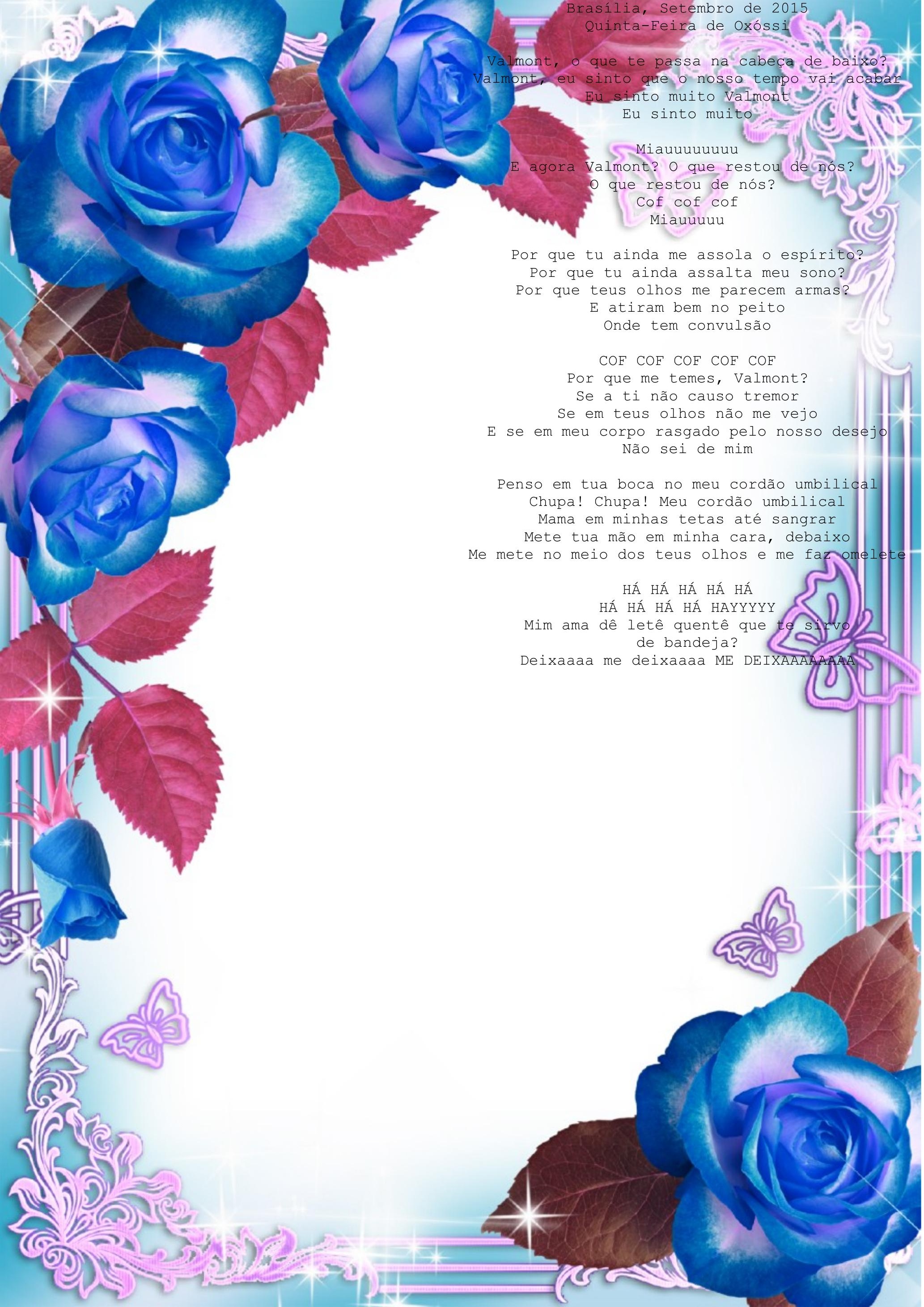




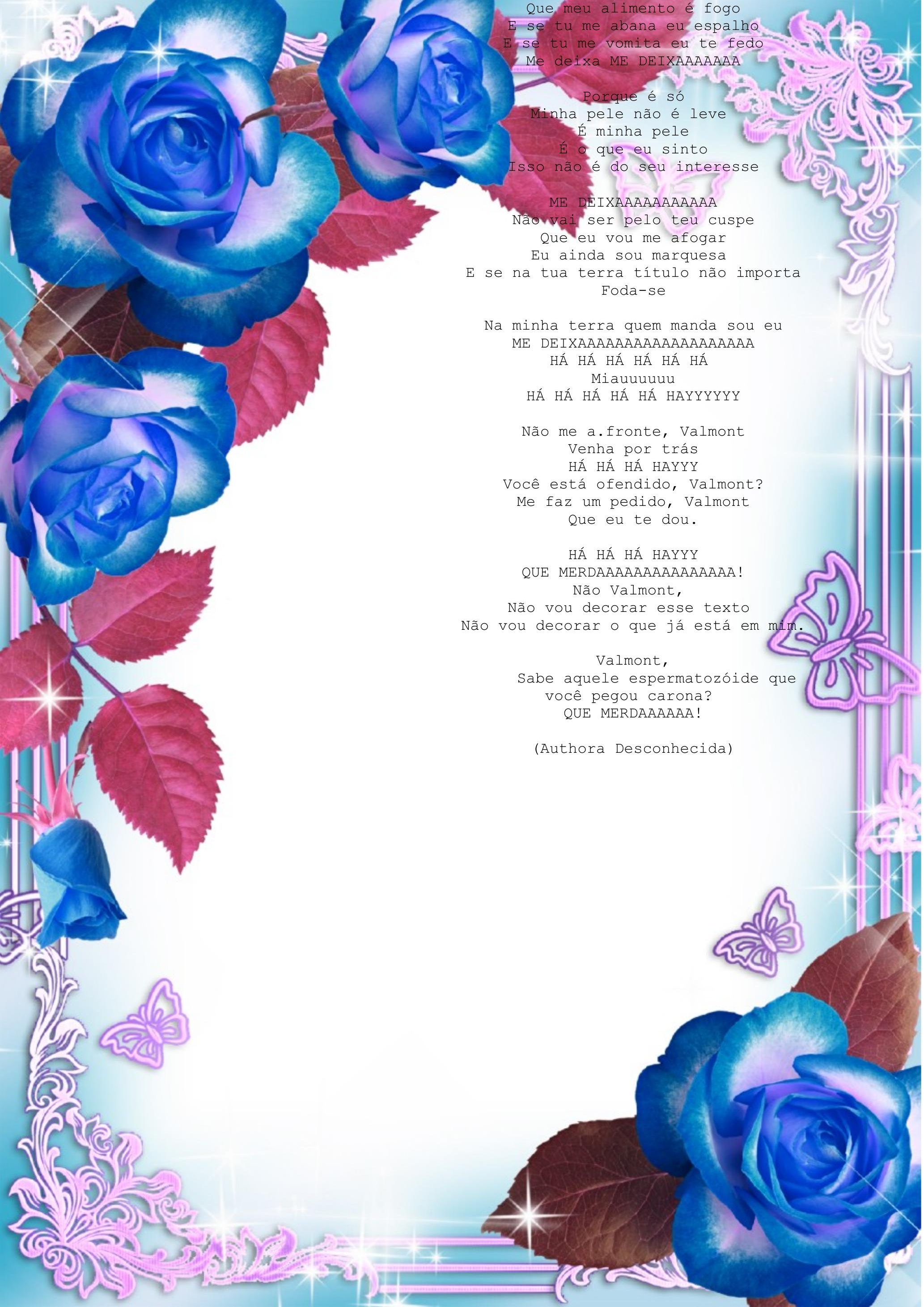


Com o regresso de Gabrielly, tentamos esquematizart os exercícios que pudessem resgatar em nosso corpo sensações e ligações com o texto. Isso para a nossa criação não funcionou. Em outro dia de tratamento levamos calcinhas doadas por amigas, bulas de remédicos, algumas roupas, música de forró, brega melody, numa tentativa de encontrar Müller Mulher, Merteuil e Valmont por via de uma dança nostálgica. Não nos aquecemos, nem alongamos ou fizemos qualquer exercício tido como atividades para despertar o corpo ou prepará-lo para a cena. Olhei para as bulas e informei a Gabrielly que Valmont havia me enviado cartas, Gabrielly leu uma das bulas como carta de amor... Assim começamos nosso tratamento, brincando com as bulas, com as calcinhas, com os outros elementos que havíamos levado. Todo o tratamento foi caótico, dito pelo corpo em brincadeira, animalesco e intuitivo.

Brasília, setembro de 2015

Terça de Ogum - 29.09

Me sentia perdida, foi explicado antes como seria, no momento que chegamos apenas fizemos. Aí teve muita coisa intensamente, porque a gente começou a coisa que aconteceu. Ai rolou as coisas assim, porque a gente tem um altar e sofrência, porque todas sofrem. Temos a santa mexicana que é sagrada e profana. É serio e não é sério. Aí, aprendemos a técnica do canto cigano que resgatou um sofrimento ancestral em minha pessoa, um sentimento caverna que está na musculatura do cu. É sinto pelo cu. Descobrimos o segredo juntas, aí apareceu essa vozZzZzzZz que a gente está tentando ainda, ai ela permeou os dias de coisas. Aí, entramos em uma coisa mais sensorial, um resgate de si mesmo, foi o dia do retorno de Saturno, retorno as identidades, sensações de Cosme Damião. E é uma coisa comida. Que tem gosto. Tem cheiro, sentidos. E é a coisa que vai se formando fazendo, a gente não sabe, pelo menos eu não sei. E aí vai clareando aos pouquinhos o que vai ser e se não vai ser. Eu sei que é de rua. E eu sinto que os cachorros vão entrar no meio, os moradores de rua vão chegar, vai atrair essa galera que vai se identificar, umas loucuras em várias aspas. É brega.

Esse processo é tateando, os outros processos que eu faço eu sei de cabo a rabo a maioria. Eu sei a linha que vai seguir. Aqui tínhamos o texto, a vontade e foi se formando. É um perdido se buscando e nem buscando as vezes só fazendo sem se buscar. Como já tem, a gente já internalizou o que quer, aí vem as ações as coisas. (Brennda Gabrielly)

O texto de Müller Mulher para a nossa pecinha existia, mas não era o foco. Se sabia da história, das palavras, das características de cada personagem literário, mas o corpo, com sua maneira de se comunicar respondia diferente do papel e era isso que procurávamos sem saber detalhado o como chegar. Kantor $(2008$, p.15) escreve " [...] sobretudo do ponto de vista literário, que, aviltando-se cada vez mais como reprodução estúpida de cenas da vida, perde irremediavelmente o instinto do teatro, o senso de liberdade criativa e a força de suas próprias formas de expressão e ação". Qual o meu papel? O que quer meu papel? Qual o papel do ator? Restringem corpos com suas experiências a experiência do papel. O papel só é importante porque essa importância é dada para ele. O papel sem alguém que o tateei não chora. $O$ teatro instinto.cio.(a)nalizado. Como Safra (2004, p.89) afirma "A coisa é mensageira do outro". Para a nossa pecinha queríamos buscar outra maneira de expressar nosso corpo em uma 
prática teatral, que se descolasse do papel. Sem saber o que poderia ser chamávamos nosso processo de coisa. Coisinha.

Marcamos de estar com nossa roupa de trabalho, isto é, com roupas de festas usadas em formaturas, casamentos, batizados e quinze anos, devidamente maquiadas tendo como inspiração a maquiagem conceitual de Yeflain. Levo algumas músicas para o nosso trabalho, entre elas música da Madonna e músicas famosas da década de 80 . O próprio ato de se maquiar e se vestir com as músicas de fundo já criava um corpo festivo e jocoso em nós. Para a nossa pecinha alguns elementos se tornaram importantes como: um amplificador e um microfone. O microfone ampliava nosso corpo, nos dava poder, era um portador de mensagens que eram ouvidas querendo ou não. Com um dia de ensaio conseguimos descobrir o que seria a nossa pecinha de teatrinho. Na Fig. 20 a imagem de divulgação da pecinha.

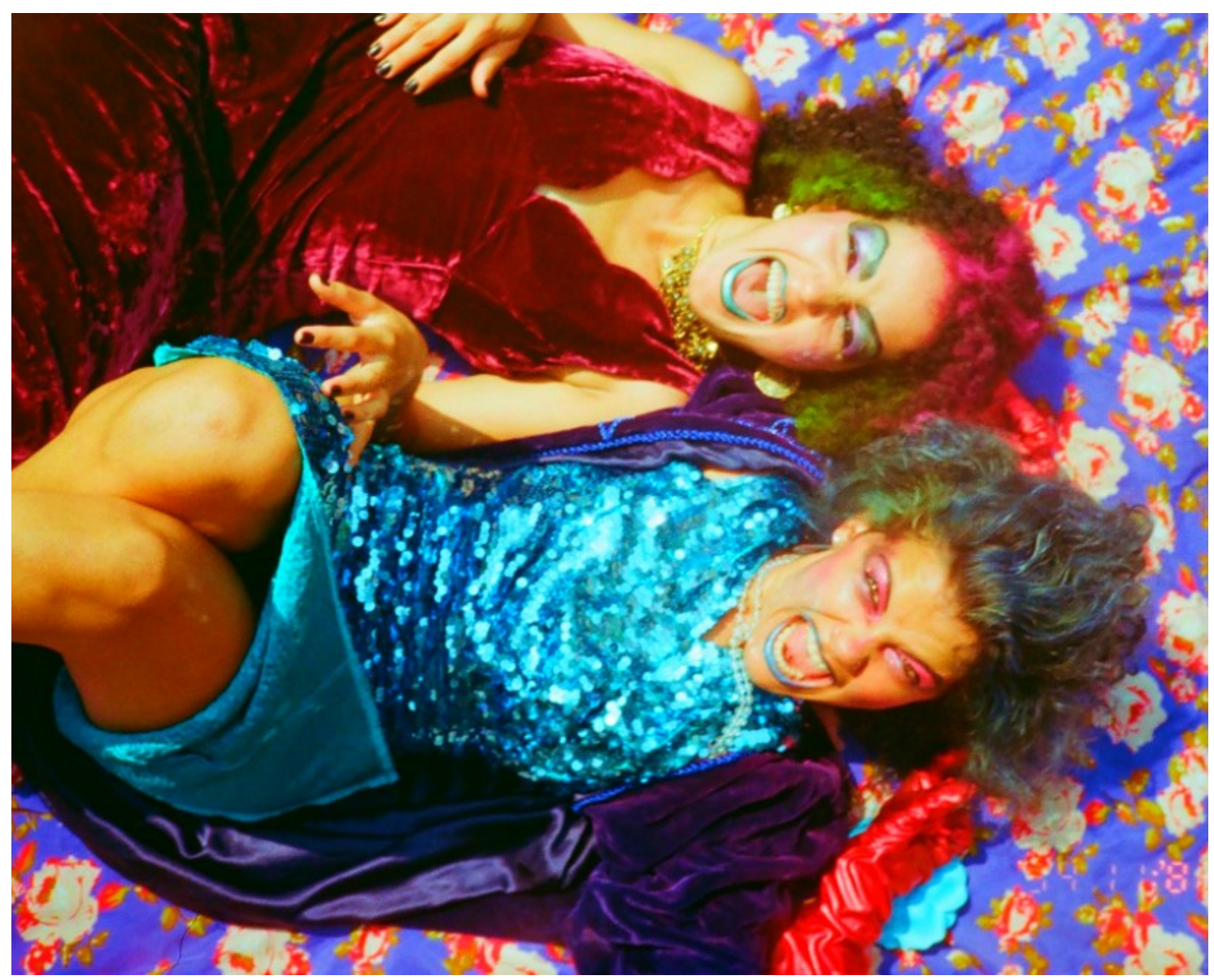

Fig. 20 - Ensaio de Merthelinny e Merthiolate para a revista Vogue Brasil.

O nosso lugar santo desmembrou Merteuil em Merthelinny e Merthiolate, no lugar da Santa Muerte a nossa Ave Maria Santa Loca, Valmont não era apenas a figura masculina na peça de 
Müller Mulher. Valmont se transformou em relações, nossas relações perigosas com homens, com lugares afetivos de nosso corpo, social. Merteuil se converteu em Mulher Mater Dolorosa, que em um labirinto de suas dores faziam todos cair na mesma cova que a dela. Quarteto então, saiu do armário como $m \& m z$, from hell with love $<3$. Não falávamos do romântico, do amor e do sexo, festejávamos o gozo do nosso sorriso banguela, era nosso corpo jogado para os pombos.

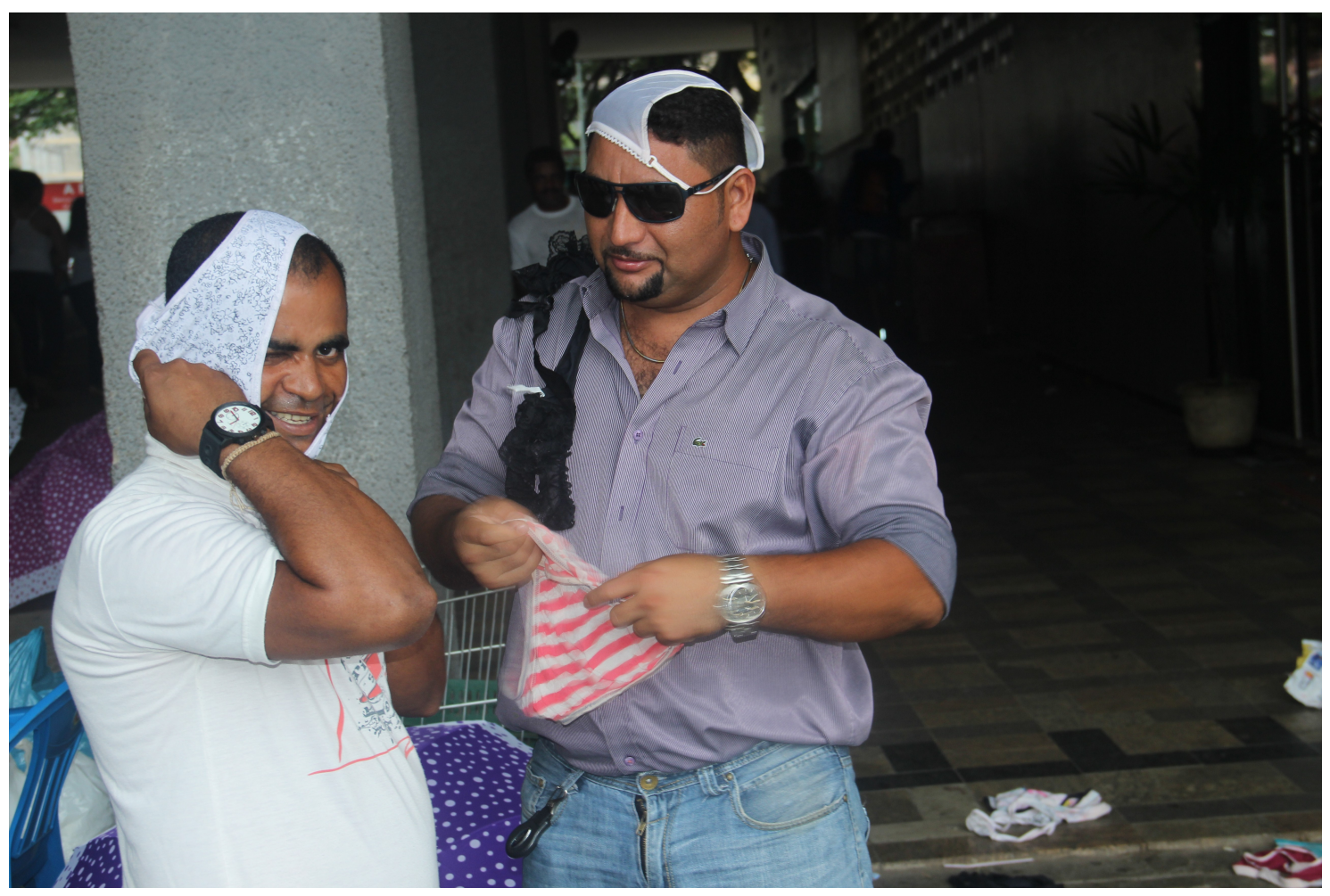

Fig. 21 - Galeria dos Estados-DF. Calcinha para homens. "Que Porra é Essa?"

Nossa pecinha passou a se constituir de breves ações improvisadas, sabíamos o que seria esta improvisação ${ }^{121}$, mas não sabíamos como ela se daria na hora da apresentação, se durante a improvisação, nas ruas, iria haver algum resgate do que aconteceu durante o tratamento, como o corpo responderia a rua e aos estímulos recebidos. As cenas não foram repassadas a fim de manter a sujeira, nunca foram improvisadas ou ensaiadas nas ruas, a não ser em um dia em que realizamos uma saída vestidas enquanto outras de nós, Serres $(2004$, p.56) "O outro faz com que minha carne se misture a ela própria: além do animal que também habita em mim, em meu corpo entram todos os outros [...] perdido em meio a esta grande multidão que me anula, desapareço como uma pequena nuvem de vapor". Na rua nos chamavam de PombaGira, lindas, perguntavam se erámos de teatro, tiramos fotos com pessoas que se interessaram,

${ }^{121}$ Tínhamos um cartaz como cardápio da pecinha, para nos nortear. Mesmo fazendo algumas ações, não conseguimos seguilo à risca. 
levamos assobios, sorrisos, caras feias, como mostra a Fig 21.

Brasília, outubro de 2015

Valmont, você chegou que nem relampejo entrecruzando seus dedos amargos entre os fios do cabelo forca. Você anda atrás de mim parecendo ser meu rabo. Às vezes vou com sua cara com um imenso sentimento de pena e as vezes prefiro te ver galinha, seu real corpo. Porco. Valmont quantas de mim já não foram embora por sua causa? Quantas de mim que se escondem assombradas, devido suas entradas triunfais? Não te envergonha achar que devemos ficar na palma da tua mão? Não me sinto confortável com teu cheiro exalando. Ardem meus olhos. Não sou teu docinho e se fosse para ser um docinho, eu seria cajuzinho, porque ninguém come. (Authora Desconhecida)

Algumas dificuldades foram encontradas para realizar nossa pecinha, a começar pela logística para transportar o material eletrônico ${ }^{122}$ da cena, determinar os locais ${ }^{123}$ de apresentação, o clima $^{124}$ da cidade, e indagações pessoais a respeito do que estávamos fazendo, para quê estávamos fazendo e por quê queríamos fazer. Minhas perguntas não teriam outras respostas que não fossem egoístas. Meu corpo precisava expulsar o grito, foi pelo social que me calei e é pelo mesmo social que vomito. O Leite de Rosas de Merteiul que entra é o que faz meu suor sair cheiroso, Fig. 22.

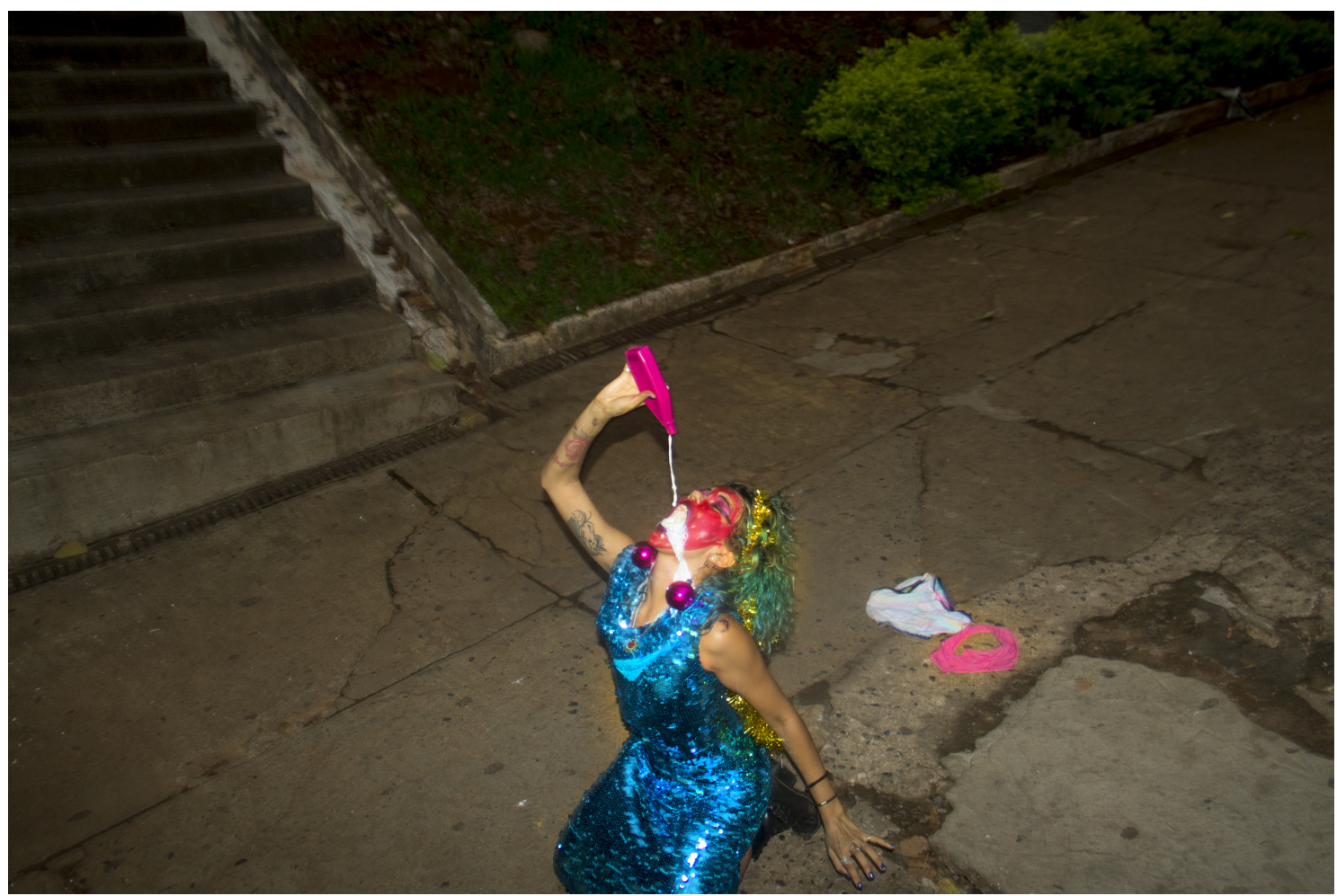

Fig. 22 - Setor Comercial Sul-DF, ficando cheirosa por dentro.

Ao conversar com alguns artistas sobre a pecinha, algumas perguntas, a respeito do nosso

\footnotetext{
${ }^{122}$ Contamos com a ajuda de amigos para transportar o gerador. Grata a Carol Palmeira, Natasha de Albuquerque e a Maria Beatriz de Medeiros por ceder o material.

${ }^{123}$ Havíamos pensado em nos apresentar em espaços que possuíssem um bom fluxo de transeuntes e que saísse da lógica do Plano Piloto/DF.

${ }^{124}$ No fim do ano, geralmente, no Distrito Federal chove muito.
} 
processo, eram feitas, dentre elas: Se iríamos fazer ensaio aberto para mostrar o Work in Process $^{125}$, se não iríamos experimentar a pecinha na rua para ver a reação do público e se sabíamos a duração da apresentação. Não percebo, enquanto intenção de uma estética PósTraumática, haver a necessidade de ensaios abertos, pois para o corpo chegar em algum local ele deve antes de qualquer coisa chegar ${ }^{126}$ com o corpo que tem. Não tínhamos a pretensão de experimentar nossa pecinha na rua, pois o que penso ser um corpo Pós-Traumático é o corpo do imediatismo. Os corpos mudam todos os dias, e o meu corpo que chega trazendo uma apresentação artística é recebido, acolhido, expulso ou ignorado por aquele que compartilha o espaço da rua comigo. A respeito da duração, isto era algo que não tínhamos ideia, apenas sabíamos que as pessoas passariam e que se alguém fosse ficar seriamos nós, que nem as paredes, que por fim são as únicas que ficam.

\section{Brasilia, outubro de 2015}

Artaud. Hoje chegamos ao nosso último dia de ensaio na salinha da UnB. Ainda estaremos experimentando as coisas, só que agora em outro espaço. E até acho que será melhor, porque vamos aos poucos para a rua. A caminhada vem a cada degrau. Voltei do ensaio me sentindo mais forte. Não sei. Estou me sentindo grande, nada a ver com vaidades, mas sinto que tenho 3 metros. A nossa pecinha não sei se está a gosto, acho que exageramos no tempero e quando o tempero está demais não dá para tirar mais da panela. Se come fazendo careta. Agradeço Artaud, a tudo que já passou pelo meu corpo me atravessando e deixando partes de minha carne pelo caminho. Estou feliz. Ainda enrugando a testa e contraindo os lábios, mas me sinto saindo do meu sarcófago. Quero chorar. O meu corpo hoje tenta expulsar o que nele já armazenaram. Já passou da validade. Me sinto pensativa. Revendo minha prática como artista. Estou achando que posso voar e é tão gostoso criar asas. Vou deixar a minha camisa de força no armário, naquela terceira gaveta que sempre fica o passado. Agradeço imensamente a todos que dão um estralo diante de nossos olhos. Preciso acordar. Artaud, obrigada. (Authora Desconhecida).

Apresentamos $m \& m z$, from hell with love $<3$ durante os dias 24,27 e $29^{127}$ de novembro de 2015, nos locais Galeria dos Estados, Setor Comercial Sul e Feira da Ceilândia, todos no Distrito Federal. As apresentações foram conturbadas, em especial por questões de organização e material técnico. No primeiro dia, o gerador que usávamos quebrou, mas conseguimos com os lojistas uma tomada para ligar o som. No segundo dia o gerador funcionou, mas nossas músicas não conseguiram pegar por mau contato, então usamos o celular com o microfone. No terceiro dia, não conseguimos levar o gerador, usamos uma tomada de uma loja de sapatos, que não gostou muito e desligou o som. Aprendemos que o gerador gera dor, uma lástima. Em nenhum dos dias tivemos problemas com a chuva e não fomos expulsas com agressões, mas fomos expulsas no último dia de apresentação porque louvávamos a Satanás, Fig. 23.

\footnotetext{
${ }^{125}$ Terminologia utilizada por Renato Cohen para descrever “ [...] progresso temporal e processualidade”. (Cohen 2006, p.XVIII)

${ }^{126}$ Aprendizado de primeiro dia no Hospital Ulysses Pernambucano.

${ }^{127}$ Participação no evento Corpo, Performance e Politica, produzido pelo Corpos Informáticos.
} 


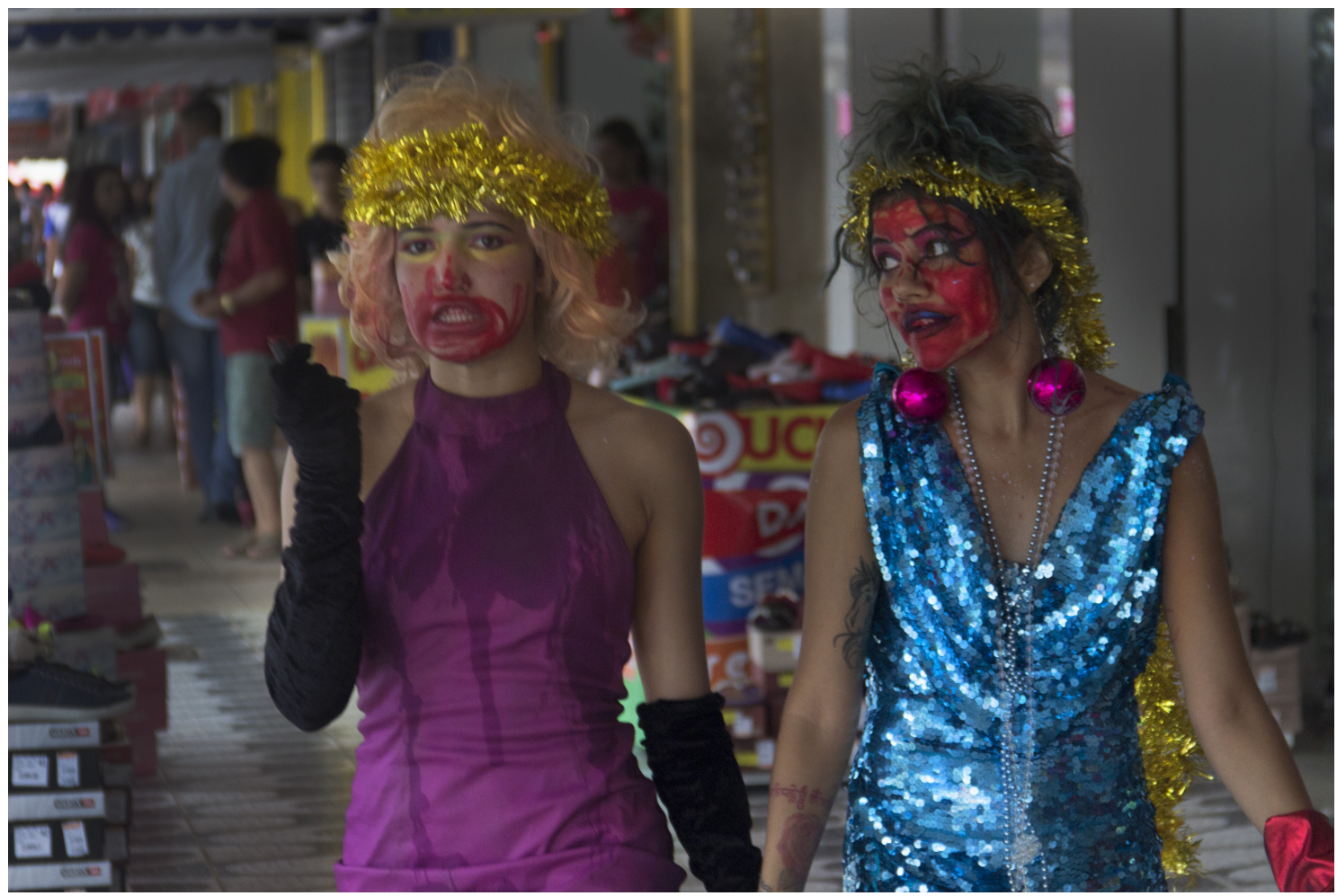

Fig. 23 - Feira da Ceilândia-DF Fashion Week.

Tínhamos um cardápio de ações a serem realizadas, porém com a experiência do primeiro dia de apresentação eliminamos boa parte do material de cena, como um carrinho de feira utilizado enquanto altar da Ave Maria Santa Loca. Reduzimos nossas ações pelas imagens que eram mais fortes, para nós, e condensamos as ações do cardápio para as improvisações do momento. Abríamos nossa pecinha, perninha, fazendo uma oração a Ave Maria Santa Loca ${ }^{128}$ e propaganda da Marcha a Satanás ${ }^{129}$, realizamos uma meditação com mantra ${ }^{130}$ e o dedo médio como união entre terra e céu, o $O M^{131}$ como uma prática ancestral para o equilíbrio humano e trabalho de aquecimento vocal com boquete no microfone. Iniciávamos nosso trabalho. Dançávamos contato improvisação e com a técnica de Mata Grama ${ }^{132}$ e Pina Abaixa $^{133}$ ao som da música de John Cage ${ }^{134}$ e texto de Heiner Mulher, junto aos prédios de OdeBrecht $^{135}$, tomando Tylenol ${ }^{136}$ e fazendo propaganda da nossa Black Vale ${ }^{137}$ com

\footnotetext{
${ }^{128}$ Oração apresentada no inicio da dissertação e necessária para a abertura dos trabalhos.

${ }^{129}$ Marcha a Satanás realizada no dia 07 de novembro de 2015 no Distrito Federal.

${ }^{130}$ Gayatri Mantra cantado por Deva Premal.

${ }^{131}$ Palavra sânscrita que significa aquilo que te projete e abençoa.

${ }^{132}$ Martha Graham. Dançarina e coreografa estadunidense.

${ }^{133}$ Pina Bausch. Dançarina, coreografa e diretora alemã.

${ }^{134}$ Canção Maniac, interpretada por Michael Sembello.

${ }^{135}$ Odebrecht. Empresa de construção civil e outros.

${ }^{136}$ Remédico para dores.

${ }^{137}$ Black Friday é um evento que acontece durante o ano com promoções no mercado. Vale é uma empresa brasileira que causou a maior destruição ambiental da história do país.
} 
promoções de calcinhas à $\mathrm{R} \$ 1,99$.

- Estou borrada? - dizíamos enquanto o batom escorregava em nossos rostos. - Senhora? Senhora? ${ }^{138}$ Isto está sendo bem encenado? ${ }^{139}$.

Eles passavam, uns ficavam, outros gozavam, as crianças riam e acenavam. Era tempo de se alimentar. Müller (1980, p.10) ${ }^{140}$ "A inveja do leite em nossos seios é o que o torna carniceiro. Se você pudesse parir! Lamento, Valmont, que esta experiência lhe é negada, este jardim lhe é proibido, devido uma decisão da natureza difícil de entender". Com um frasco de Leite de $\operatorname{Rosas}^{141}$ nos banhávamos, do leite da vaca que é nosso, caíamos por cima da marca do leite no asfalto, leite de nossa morte, leite de sangue. Tradução da música da cantora Madonna ${ }^{142}$, dança traduzida ${ }^{143}$ em dança contemporânea. Valmont embora? Os aplausos vinham porque “Batemos as mãos mecanicamente". (BROOK, 2008, p.284). Pedíamos por aplausos, como grandes atrizes formadas por escolas pomposas e se quiserem podem aplaudir, isso aqui também acabou.

\footnotetext{
${ }^{138}$ Referência ao vídeo viral de uma reportagem televisiva. Senhora: https://www.youtube.com/watch?v=3tZYtddBgds

139 "That was well played, no?" (MÜLLER, 1980, p.1)

140 "The envy for the milk of our breasts is what makes you into butchers. If you could only give birth. I regret, Valmont, that this experience will be denied to you, this garden forbidden, due to a decision of nature which is difficult to understand."

${ }^{141}$ Marca de hidrante corporal.

${ }^{142}$ Madonna canção Hung Up tradução Use Renew, marca de cosmético que promete remover marcas de expressão do rosto e deixar a mulher mais jovem.

${ }^{143}$ Música traduzida em dança Me Libera, interpretada por Banda Dejavu
} 


\section{CONCLUSÃO:}

CARTA 0 PARA ARTAUD

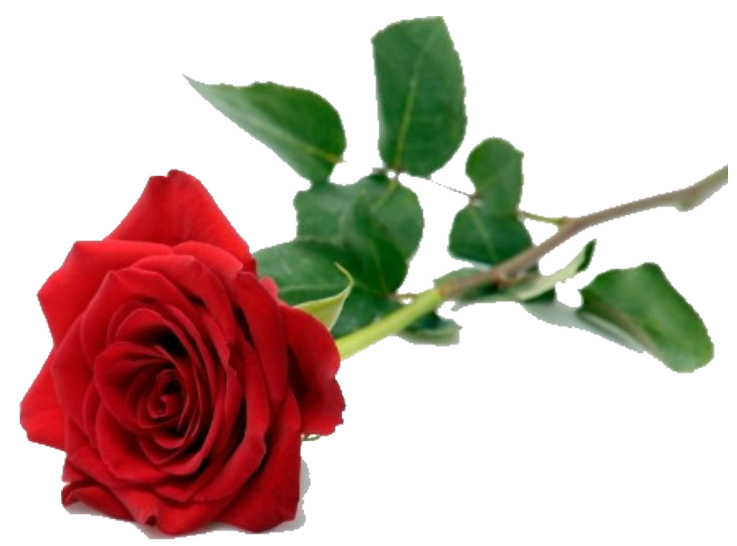

Brasília, 22 de fevereiro de 2016

Artaud, sou eu de novo. Como você está? Por esses dias passei no nosso corredor e não te vi mais lá. Queria me despedir de você, acredito que vou passar um tempo sem te escrever. Sabe, preciso respirar, me sinto cansada da vida. Mas não se preocupe! Não estou te abandonando. Você ainda anda nos meus passos. Estas últimas linhas estão sendo uma tortura para mim. Não sei se é por rever todo processo que passei até chegar às últimas páginas desse trabalho, se é drama de um mapa leonino ou se é essa lua que está quase cheia. Eu ainda não aprendi a encerrar coisas e tenho problemas em me expressar nessas situações.

Artaud, sou passional e tanto já mudou. Voltei a Recife por esses dias e participei do carnaval, aquela festa que não é a sua cara, com o Doida de Pedra lá no HUP. Revi alguns pacientes com os quais eu estive em contato em 2013, revi aquelas paredes de um rosa pálido, andei pelos buracos do prédio. Foi muito bom estar lá de novo e perceber que uma história de projeto dançava em minha cabeça, tenho até uma água no olho direito querendo descer, mas não desce. Voltar ali me fez perceber que continuo com aquela sensação de que ainda não estamos prontos para receber o outro. O estranho não sensibiliza, não é levado para casa, porque ele não agrada aos olhos e não me vejo em sua estranheza. O estranho é estrangeiro ao meu mundo e mesmo que seja gente, feito por gente, para a gente, sua história é negada porque é diferente e o diferente não consegue comer pelas beiradas e quando percebido ele é comido pelo meio.

Não vou mentir, meu amigo. Esse projeto chegou ao meu corpo por via espiritual, e eu acredito, e muito, na magia do não saber. Fiquei durante muitos momentos da pesquisa de mestrado insegura com o que eu estava fazendo. Não consigo separar minha arte do que me move. Senti medo de estar sendo invasiva, de estar sendo aquela que faz uma piada em velório, não para querer ser engraçada, mas por querer "quebrar o gelo". Nunca tomei remédico psiquiátrico enquanto estive doente, fiz duas vezes terapia e juntando as duas durei 
quatro meses. Nunca fui internada em clínica para tratamento psiquiátrico. Nunca tive um Pato que olhasse pra minha cara e dissesse:

- Você tem qua, qua, qua.

Eu tenho desejo de mundo e um medo enorme de comê-lo. E queria até pedir desculpas, a você Artaud, e a qualquer outra pessoa que eu possa ter machucado com o meu brilho nos olhos. Enlouquecer eu não quis, mas trabalhar com isso e ainda pesquisar a respeito eu fiz. Não desmereço minha dor e a forma como a abracei, mas sinto que sou uma piada.

Continuo acreditando que somos experiências que nós nos permitimos viver e aquelas que nos pegam desprevenidos. Somos a sola que gastamos só ou mal acompanhados. Tive a linda oportunidade de permitir ao meu corpo estar fora de sua zona de conforto. Não sou psicóloga, não sou psiquiatra, não sou arteterapeuta e apesar de um diploma que me diz arte educadora, eu não sou. Sou azul, artista e como artista que ficou, tantas vezes, nas experiências em hospital psiquiátrico oscilando entre minha prática artística autoral, produtora de projeto e ser humano que se abria a tantas mãos que me tocavam, sinto que, muitas vezes, me deixei para depois, não por puritanismo e por ser garotinha altruísta, porque isso eu também não sou. Mas porque eu me esqueci de ser urgente no meu dia-adia. Então resolvi sair do Doida de Pedra, acho que meu tempo ali fez um fade out.

Artaud, o que é corpo? Ontem tomei ayahuasca ${ }^{144}$ pela primeira vez. E acho que você apareceu lá. No primeiro momento dormi. Quando acordei estava me sentindo um pouco enjoada. Vi muitas mandalas, se abrindo e se fechando, mandalas de cores fortes, linhas finas, o chão, as cadeiras, as pessoas, nos meus olhos fechados, tudo virava mandalas. E mandalas que se mexiam em sentindo horário e anti-horário. Achei que eu ia vomitar, mas você foi muito mais esperto. Você me deixou com as pernas fracas, o corpo parecia uma gelatina, o vômito não descia, só cuspe, só cuspe, só cuspe. Quando voltei ao meu lugar um frio que meu corpo não aguentava, minha segurança era um muro murro onde eu podia encostar a cabeça, que também era feito de mandalas. Essas se mexiam. E tudo mexia e aquilo não passava. Meus olhos arregalados, um olhar inquieto, eu era um saco encolhido na cadeira, um vácuo dentro do cobertor, um ser que às vezes pensava que aquilo iria ser para sempre. Até que alguém me disse, e Artaud, eu tenho certeza que foi você:

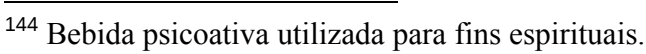


- Você não queria saber como é a cabeça de um psicótico? É assim.

Ainda não digeri essa experiência. Sai da minha casa acreditando que o corpo era um peso de papel, ou uma mão na cara, ou uma porta fechada que tem que fazer "toc, toc, toc" para ver se tem gente. Trouxe tantos autores para este texto que pudessem clarear as minhas ideias sobre como experienciar esse corpo, na saúde e na doença, na alegria e na tristeza. Eu os declaro marido e mulher. Procurei em outras bocas as suas experiências, procurei em meu corpo o que ele me falava, mas geralmente ele gritava, me dizia coisas emboladas e eu não ouvia direito. O corpo não é massa. Não tem dois pesos e duas medidas. Tem tanta gente que mora dentro de mim, sou in.diví.duo. Seria uma ilusão acreditar que eu respondo sozinha pelos meus próprios atos, mesmo tendo uma sensação de que estou só e me sinto buscando uma multidão de um corpo outro para encostar minha cabeça. Busco como quem não tem pressa, porque não gosto do gosto da comida quente e vou aprendendo que corpo é magia e ele sabe a hora de desaparecer. Artaud, nesta experiência, você passou suas unhas sujas no meu braço direito e me mostrou que o corpo é o sentir. Depois você riu e me deixou rindo com as paredes. Como você sempre faz e eu sempre agradeço. Eu sinto muito.

Querido, queria compartilhar com você outra experiência. Vou te confessar. Dormi vendo o Tadashi Endo. As pessoas ao meu lado choravam e eu pensava em zZz... Artaud! Não sei o que faço aqui! Nesse meio teatral. Nem sei por que eu fiz a pecinha de teatrinho m\&mz, from hell with love <3. Nem sei se você vai ler minha carta, então pra quê escrevo? Onde está o meu prazer nisso? Não sinto meus olhos estatelados e sinceramente eu não morreria pelo teu palco sagrado. Artaud, não vejo muito as caras dos diferentes do teu espaço. Não entendo. Por que ele só escolhe o que é do agrado? O bonitinho. O teatro limpinho, organizadozinho, fofinho, engomadinho, o que tem muita técnica, o que sabe fazer aquilo que você não sabe fazer, porque não te interessa. Hoje, todos lembram de você com uma nostalgia de quem viveu junto, mas não olham ao redor, não olham a tua cria que está tão próxima, tão calorosa, e quando olham, desviam os olhos para o céu. Não digo que eu repouso debaixo das tuas asas, mas sinto vontade de voar e agradeço àqueles que já estão se divertindo aí por cima. Às vezes quero dar os meus sonhos para outros viverem... Artaud, o público é privado. A audiência dá na TV. E o pintinho piu.

Ainda sinto que vou brincar muito tentando encontrar aquilo que vai me fazer perder a cabeça. Que nem a Vitória de Samotracia, lembra? Vou achar o meu teatro poético de 
palavra chulas, de quadril rebolation ${ }^{145}$, de corpo ChicQueiro, de processo criativo com sotaque portunhol. Vai ser tanta purpurina, lantejoula e cetim sem elastano que vai faltar nas roupas das passistas de escola de samba! Vou chegar ao Teatro Pós-Traumático, e se não chegar, pelo menos sai do meu lugar, de novo. Algo me move nele, suas luzes em neon me convidam para entrar. Há vagas. Só que eu sou muito adulta para isso e sinto que preciso ir de encontro a petulância da criança. Um retorno de Saturno para um céu de grandes bochechas, boca meia lua e estrelas arregaladas.

Então é isso, Artaud. Estou feliz, mas preciso te deixar por um tempo. Você é pesado demais e eu não aguento tanto. Sinto que a santíssima Ave Maria Santa Loca está se aproximando e pedindo o teu lugar ao meu lado. Todo mundo tem um pai e uma mãe, não é mesmo? Eu tenho vários que cuidam de mim em diversos níveis. Sou filha de um rebanho e estou aprendendo a viver com isso. Mas antes de pegar minha carroça cigana e partir, quero te dizer que sinto que o hospital hospitaleiro vai cair. Vai cair por nossas cabeças se a gente não derrubá-lo antes. Está tudo instinto.cio.nal. Nos prendem entre pontos e aspas. Estou sem forças para dar meu braço, Artaud. E sinto também, que finalizo este trabalho sem saber cozinhar, sem saber usar "a" craseado, diferenciar "este" de "esse" e colocar vírgulas separando as orações. Amém? Amem.

\section{REFERÊNCIAS BIBLIOGRÁFICAS}

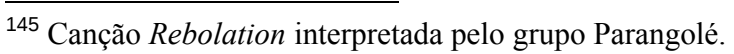


ARTAUD, Antonin. Van Gogh el Suicidado por la Sociedad. Buenos Aires: Editorial Argonauta, 1971 .

Ediciones Caldén, 1975.

Para Terminar con el Juicio de Dios y Otros Poemas. Buenos Aires: . El Momo y Otros Poemas. Buenos Aires: Caldén, 1976.

. Os Tarahumaras. Portugal: Relógio D’água, 1985.

. En plena noche o el bluff surrealista. Espanha: El Aleph, 1999.

. El Ombligo de Los Limbos / el pesa nervios. Sem informação: Sem

informação, 2002.

. Linguagem e Vida. São Paulo: Perspectiva, 2008. . O Teatro e Seu Duplo. São Paulo: Martins Fontes, 2013.

BAKHTIN, Mikhail. A Cultura Popular na Idade Média e no Renascimento. São Paulo: Hucitec, 2010.

BOURRIAUD, Nicolas. Estética Relacional. São Paulo: Martins Fontes, 2009.

BRETON, David Le. Antropologia do Corpo e Modernidade. Rio de Janeiro: Vozes, 2003.

BROOK, Peter. O espaço vazio. Lisboa: Orfeu Negro, 2011.

CAO, Santiago. D(en)ominar. (Des)cobrir. Esquecer. Bahia: Festival Mola (mostra Osso Latino Americana), 2013.

CARVALHAES, Ana Goldenstein. Persona Performática: Alteridade e Experiência na Obra de Renato Cohen. Rio de Janeiro: Perspectiva, 2012.

COHEN, Renato. Work in Progress na Cena Contemporânea. São Paulo: Perspectiva, 2006.

COTRIM, Cecilia (Org.). Escrito de Artistas: anos 60/70. Rio de Janeiro: Jorge Zahar Editor, 2006.

DAlGALARRONDO, Paulo. Psicopatologia e Semiologia dos Transtornos Mentais $2^{a}$. Porto Alegre: Artmed, 2008.

ECO, Umberto. Obra aberta. São Paulo: Perspectiva, 2007.

FREUD, Sigmund. Sigmund Freud: Obras Completas Volume 14: História de uma Neurose Infantil, o Homem dos Lobos. São Paulo: Companhia das Letras, 2010.

GÓMEZ-PEÑA, Guillermo; PEÑA, Elaine (Ed.). Ethno-Techno: Writings on Performance, Activism, and Pedagogy. New York: Routledge, 2005. 
JODOROWSKY, Alejandro. Psicomagia. São Paulo: Devir, 2009.

KANTOR, Tadeusz. O teatro da Morte. Perspectiva: São Paulo, 2008.

LORCA, Federico Garcia. Sonetos do Amor Obscuro e Divã do Tamarit. São Paulo: Folha de S. Paulo, 2012.

MAFFESOLI, Michel. Elogio da Razão Sensível. Rio de Janeiro: Editora Vozes, 1998.

MEDEIROS, Maria Beatriz de. Aisthesis. Chapecó: Argos, 2005. FERREIRA, Gloria;

MEDEIROS, Maria Beatriz de; AQUINO, Fernando (Org.). Corpos informáticos: Performance, Corpo, Política. Brasília: Editora do Programa de Pós-graduação em Arte, 2011

MILLET, Maria Alice. Lygia Clark: Obra e Trajeto. São Paulo: Editora da Universidade de São Paulo, 1992

OSTROWER, Fayga. Criatividade e Processo de Criação. Rio de Janeiro: Editora Vozes, 2009.

PANKOW, Gisela. O e Sua Psicose. São Paulo: Editora Papirus. 1989

PESSOA, Fernando. Livro do Desassossego. São Paulo: Editora Brasiliense, 1986.

ROSA, João Guimarães. Tutaméia (Terceiras Estórias). 8ª Ed. Rio de Janeiro: Nova Fronteira, 2001.

SAFRA, Gilberto. A Po-ética na Clínica Contemporânea. São Paulo: Ideias e Letras, 2004.

SERRES, Michel. Variações Sobre o Corpo. São Paulo: Bertrand Brasil, 2004.

SONTAG, Susan. A Doença Como Metáfora. São Paulo: Companhia das Letras, 2007.

WANDERLEY, Lula. O Dragão Posou no Espaço: Arte Contemporânea, Sofrimentos Psíquico e o Objeto Relacional de Lygia Clark. Rio de Janeiro: Rocco, 2002.

\section{REFERÊNCIA: DISSERTAÇÕES E TESES}

BASTOS, Lúcia Kopschitz Xavier. Anotações sobre leitura e nonsense. 1996. 127 f. Tese (Doutorado) - Curso Pós-Graduação em Linguística, Universidade Estadual de Campinas, Campinas, 1996.

DAMASCENO, Letícia. Dança e Criação: A memória Corporal Numa Abordagem Nietzschiana. 2009. 124 f. Dissertação (Mestrado) - Universidade Federal do Estado do Rio de Janeiro, Rio de Janeiro, 2009. 
FONTANELLA, Israel. A estética do brega: cultura de consumo e o corpo nas periferias do recife. 2005. 138 f. Dissertação (Mestrado) - Curso de Pós-graduação em Comunicação, Universidade Federal de Pernambuco, Pernambuco, 2005.

FURTADO, Juarez Pereira. Corpo e Loucura: Histórico Das Formas De Intervenção Sobre O Corpo Na Psiquiatria. 1995. 78 f. Dissertação (Mestrado) - Curso Pós-Graduação em Educação Física, Universidade Estadual de Campinas, Campinas, 1995.

HILKER, Regiane Rossi Aparecida. Ciganos Peregrinos do Tempo: Ritual, Cultura e Tradição. 2008. 266 f. Tese (Doutorado) - Curso de Programa de Pós-graduação em Multimeios, Unicamp, Campinas, 2008.

\section{REFERÊNCIA: ARTIGOS}

LAROSSA, Jorge. Notas Sobre a Experiência e o Saber de Experiência. in Revista Brasileira da Educação. n. 19, Rio de Janeiro: ANPED, 2002.

Ministério Público Federal. Cartilha Direito à Saúde Mental. Brasília, 2012. Haldol: Halolperidol. São Paulo: Janssen, (2012). Bula de Remédio.

NASCIMENTO, Amanda. O GROTESCO - uma análise do vídeo "O Banquete" de Anna Natale. Revista Da Pesquisa, Santa Catarina, v. 2, n. 5, p.1-8, jan. 2011. Disponível em: $<$ http://www.ceart.udesc.br/revista_dapesquisa/volume2/numero2/plasticas/Amanda PPGAV.pdf $>$. Acesso em: 15 out. 2015.

PELBART, Peter Pál. Poéticas da Alteridade. Bordas, São Paulo, n. 4, p.1-7, 2011. Disponível em: <http://revistas.pucsp.br/index.php/bordas/article/view/7734>. Acesso em: 20 set. 2015.

PELBART, Peter Pál. Manicômio Mental - A Outra Face da Clausura. In: Revista Saúde \& Loucura, n. 2, $3^{\text {a }}$ ed., p. 131-138. Editora Hucitec, 1990.

PEWNY, Katharina. Posttraumatic Theater. A Concept in Progress on the Performativity of Un/Rest. In: IWM Junior Visiting Fellow's Conferences, 2003, Vienna. Conferência. Vienna: S. Gorman, 2003. p. 1 - 16. Disponível em: <http://www.iwm.at/publ-jvc/jc-15-04.pdf $>$. Acesso em: 10 set. 2014.

ROTELLI, F. A instituição inventada. In: Per la salute mentale/ For mental health 1/88, Centro Studi e Ricerche per la Salute Mentale della Regione Friuli Venezia Giulia. Disponível em: <http://www.exclusion.net/images/pdf/47_bicoi_istituz.invent_po.pdf $>$. Acesso em: 26 abr. 2015.

THOMAZ, Nathalia Xavier. O Grotesco e o Nonsense de Alice: Diálogos desafiadores nas Produções Culturais para Crianças e Jovens. Literartes, São Paulo, v. 2, p.55-64.

\section{REFERÊNCIA: WEB}

ALBERTIM, Catarina; CALVANCANTI, Halina. Dez anos após a reforma psiquiátrica, Brasil ainda tem instituições públicas funcionando no modelo de antigos manicômios. 
Disponível em: < https://embrulhoesquizofrenico.wordpress.com/2011/06/16/dez-anos-apos-areforma-psiquiatrica-brasil-ainda-tem-instituicoes-publicas-funcionando-no-modelo-deantigos-manicomios>. Acesso em: 08 set. 2012.

MÜLLER,

em:

$<$ http://members.efn.org/ dredmond/Quartet.PDF>. Acesso em: 08 jun. 2015.

KALIL, Glória. Ser Chique Sempre!. Disponível em: <

http://somostodosum.ig.com.br/clube/artigos.asp?id=24359 >. Acesso em: 19 mar. 2015.

RAMANUSH, Ingrid. Proyecto Kheles Amensa. Disponível em: $<$ http://www.embaixadacigana.org.br/dancas_ciganas.html $>$. Acesso em: 15 out. 2014.

\section{REFERÊNCIA: MÚSICAS}

BANDA EVA. Levada a Louca. In: Beleza Rara. Universal Music, 1996. Faixa 2 (3min 51s).

BOCHECHA, Claudinho e. Fico Assim Sem Você. Moraes, C., Abdullah. [Compositores]. In: Vamos Dançar. Universal Music, 2002. Faixa 11 (3 min 56 s).

DALE. Cecília. Um Novo Tempo. In: Christimas in Bossa. Faixa 11 (6 min 19 s).

DANIEL. Estou Apaixonado. In: Ao Vivo. Warner Music, 2001. Faixa 4 (4 min 03 s).

ELIANA. Dedinhos. In: Dedinhos. BMG, 1993. CD (26:40 min). Faixa 1 (2 min 3 s).

É O TCHAN. Dança do Ventre. In: É O Tcham no Brasil. Polygram, 1997. Faixa 1 (3 min $22 \mathrm{~s})$.

FAGNER. Borbulhas de Amor. In: Raimundo Fagner. CBS, 1995. Faixa 9 (4 min 41 s).

GILBERTO. João. O Pato. In: O Amor, O Sorriso e A Flor. Gilberto, J. [Compositor]. Odeon Fonográfica, 1960. Faixa 8 (1 min $56 \mathrm{~s})$.

HYLDON. Na Rua, na Chuva, na Fazenda. In: Na Rua, na Chuva, na Fazenda. Polydor, 1975. CD (43:55 min). Faixa 1 (3 min $30 \mathrm{~s})$.

LAPADA, Companhia. Mainha, Painho. In: Companhia da Lapada. Kleber Lapada, 2012. Disponível em: < https://www.youtube.com/watch?v=OfekkwD82Fk>. (2 min 59 s).

LEONARDO, Leandro e. Entre Tapas e Beijos. In: Leandro e Leonardo Vol.3. Continental, 1989. Faixa 8 (3 min $30 \mathrm{~s})$.

LIMÃO COM MEL. Vivendo de Solidão. In: Limão com Mel - Um Acústico Diferente. Atração, 2003. CD (73:25 min). Faixa 10 (5 min 9 s).

LUCIANO, Zezé di Camargo. Você Vai Ver. In: Zezé Di Camargo \& Luciano. Sony Music, 1994. 1 CD (46:36 min). Faixa 10 (3 $\min 17 \mathrm{~s})$. 
MIRANDA, Roberta. Vá Com Deus. In: Volume 2. Warner Music, 1987. Faixa 7 (3 min 42s).

NETINHO. Milla. In: Netinho Ao Vivo. Polygram, 1996. Faixa 6 (4 min 55s).

PARANGOLÉ. Rebolation. In: Dinastia Parangolé. Nenél, A., Santana, L., [Compositores]. Universal Music, 2009, (3 min $41 \mathrm{~s})$.

ROSANA. O Amor e o Poder. In: Coração Selvagem.Mende, G., Applegate, S. M., Rouge, C., Rush, J. [Compositores]. Epic, 1987. Faixa 2 (4 min 08 s).

ROSSI, Reginaldo. Saí da Tua Vida. In: Meus Momentos. EMI, 1994. CD (48:32 min). Faixa $11(4 \min 10 \mathrm{~s})$.

ROSSI, Reginaldo. Mon Amour Meu Bem Ma femme. In: Meus Momentos. EMI, 1994. CD (48:32 min). Faixa 4 (2 min $40 \mathrm{~s})$.

SEIXAS, Raul. O Dia em que a Terra Parou. In: O Dia em que a Terra Parou. WEA, 1977. CD (34:40 min). Faixa 3 (4 min $25 \mathrm{~s})$.

TELÓ, Michel. Humilde Residência. M. Tiago, L. Malcolm, H. Luiz. [Compositores]. In: Na Balada. Som Livre, Universal Music, 2012. CD (44:40 min). Faixa 2 (3 min 13 s).

VALENÇA, Alceu. Me Segura Senão Eu Caio. M. J. [Compositor]. In: Maxximum. RCA Records, 1999. 1 CD (65:25 min). Faixa 10 (3 min 17 s).

XORORÓ, Chitãozinho e. Evidências. A. José, V. Paulo. [Compositores]. In: Cowboy do Asfalto. Philips, 1990. CD (46:43 min). Faixa 1 (4 min 54 s).

XUXA. Cinco Patinhos. In: Só Para Baixinhos 1. Som Livre, 2000. Faixa (2min 06 s).

XUXA. Libera Geral. In: Boas Notícias. Socci, A., Matta, C. [Compositores]. Som Livre, 1997. CD (52:38 min). Faixa 2 (3 min $53 \mathrm{~s})$.

YOUNG, John Paul. Love is in The Air. In: Strictly Ballroom. Columbia Records, 1992. Faixa 1 (4 min $14 \mathrm{~s}$ ). 


\section{ANEXOS OU ARRIANDO OS TRABALHOS}

\section{ANEXO 1: RELATO DE EXPERIÊNCIA e DEPOIMENTO COM A DANÇA CIGANA}

Relato de experiência e depoimento de participante da Oficina de Dança Cigana ministrada pela artista-pesquisadora no Centro de Atenção Psicossocial II (CAPS). O nome das alunas serão preservados e substituídos por nomes tidos como ciganos.

\section{O CASO DE ESMERALDA}

Antes de iniciar as atividades de dança cigana, minha supervisora do CAPS II solicitou minha participação em uma de suas reuniões para conhecer uma das mulheres assistidas pelo Centro. Ao conhecer Esmeralda senti um caso especial, delicado e desafiante. Seus olhos eram medrosos, chorava muito, não se comunicava verbalmente com ninguém do CAPS, apenas com a minha supervisora e por meio da escrita, amaciava os dedos no casaco da filha e tinha parte de sua audição comprometida.

Como as atividades no CAPS ainda não haviam começado, sugeri a Esmeralda, sua filha e minha supervisora fazer visitas na casa de Esmeralda. Ficou acordado que uma vez por semana no período de $1 \mathrm{~h} 30$ eu ficaria na companhia de Esmeralda e sua família na região do Gama/DF

\section{DIA 14 DE ABRIL DE 2014}

Um dia antes da primeira visita, confirmo com a filha de Esmeralda por telefone o encontro. Sou bem recebida por suas duas filhas, seu filho mais novo e suas duas netas, ainda crianças. Percebo Esmeralda com o rosto enfadado, afundada em um sofá. Aos poucos, tento estabelecer com ela algum contato, mas ela não interage. Esmeralda se comunicava comigo por gestos e murmúrios, porém, com seus familiares, notei que ela esboçava algumas palavras. Neste primeiro dia levo o meu notebook para sua casa e lhe mostro alguns vídeos de dança cigana e fotos das roupas usadas pela dança. Neste mesmo dia seu filho me informou que ali próximo, no bairro de Santa Maria/DF, existia um acampamento cigano que ele e sua 
mãe viram uma vez. Saindo de sua casa deixo com sua filha uma mídia com algumas músicas ciganas para que Esmeralda, apesar da baixa audição, possa conhecer. Dali, fui atrás do acampamento cigano e conheci Daiane da Rocha e os Ciganos Calons do acampamento do senhor Wanderley da Rocha.

\section{DIA 21 DE ABRIL DE 2014}

Para este segundo dia, levo duas saias ciganas, para que ela possa conhecer de perto a indumentária. Encontro Esmeralda e sua família ainda acordando. Após se organizar, Esmeralda senta em seu sofá com uma disposição corporal mais acolhedora. Mostro a ela a saia cigana e percebo em seus olhos entusiasmo. Ela toca no tecido da mesma forma que tocou no casaco da sua filha dias atrás, aponta para o tecido e balbucia algumas coisas. Expliquei-lhe como a saia era feita, os tecidos usados e assim seguimos aos poucos estabelecendo um diálogo.

Logo a seguir, na sala, aparecem suas duas netas que ao ver o colorido da roupa cigana se mostram interessadas pela atividade. Concordamos, enquanto grupo, em ter na sua pequena sala uma aula de dança cigana. Coloco cintinhos de moedas em suas netas e a saia em Esmeralda. Dando começo à aula Esmeralda se mostrou resistente, apontava para sua barriga, para os pés inchados e para as fortes dores de seu corpo. Comunico-lhe que poderíamos ir devagar, que ela teria total liberdade em parar, mas que antes de encerrar tentaríamos dançar um pouco. Fizemos então um acordo: Naquela aula daríamos mais movimentos voltados para as mãos. Ao colocar a música cigana Esmeralda se levanta, mostro a ela e à suas netas alguns movimentos e pela primeira vez vi nela um sorriso, ainda tímido, porém significativo.

- Ai meu Deus. - Esmeralda, com uma das mãos no peito, senta no sofá.

Guardei esta frase comigo enquanto todo meu corpo explodia de alegria. Pergunto a Esmeralda se ela gostaria que eu lhe aplicasse um pouco de Reiki ${ }^{146}$. À princípio hesita, pois um dos meus pedidos foi para que fechasse os olhos. Depois confia em mim e aceita.

\section{DIA 28 DE ABRIL DE 2014}

No último dia em sua casa me atrasei. Assim que cheguei sua filha mais nova me informou que ela estava perguntando se eu realmente iria. Abraço Esmeralda e ela me parecia estar melhor. Levo a saia cigana e o material para mais uma aula de dança cigana.

\footnotetext{
${ }^{146}$ Método terapêutico japonês de relaxamento, harmonização e reposição de energia.
} 
- É cetim mesmo? Quantos metros? - Esmeralda me pergunta com a fala embolada.

Passado o meu susto inicial começamos uma conversa em que Esmeralda me relatou alguns fatos de sua vida. Falou sobre as perseguições que sofria do seu ex-marido e que ele a chamava de cigana porque ela sempre se mudava para fugir dele. Me contou que tem três miomas na barriga e que está na fila para atendimento, mas que aquilo muito a incomodava. Explicou como perdeu parte de sua audição e o seu medo de ficar só, de tomar banho e de dormir sozinha, já que para ela tinha sempre alguém a seguindo. A sua filha me notificou que um dia a viu segurando uma faca e que Esmeralda dizia sem parar que iria tirar o que estava dentro de sua barriga, entre outros fatos.

Depois deste último dia de atividade, só pude ver Esmeralda mais vez em atendimento no CAPS. Por ela ser de baixa renda e não ter conseguido por vias burocráticas a isenção da taxa de pagamento nos transportes públicos, Esmeralda teve que parar seu tratamento e não pôde comparecer as atividades da dança cigana e eu não pude continuar dando assistência à Esmeralda em seu domicílio.

\section{O CASO DE SANDRA ROSA MADALENA}

Desde que Sandra Rosa Madalena rodou sua saia nas aulas de dança cigana, não mais se desligou das atividades. Estando dançante nas apresentações do grupo, me substituindo em algumas aulas quando não tive condições de estar presente e revelando em sua fala e em sua aparência as modificações positivas que estava passando. No ano de 2015, Sandra Rosa Madalena compartilhou a coordenação do grupo Ciganos de Luz DF comigo e se encontrou como voluntária nas aulas de dança cigana. O depoimento a seguir foi escrito por Sandra Rosa Madalena para um grupo do Facebook ${ }^{147}$ que discute sobre saúde mental. Sandra Rosa Madalena concedeu autorização para sua publicação nesta dissertação.

\section{DIA 25 DE JULHO DE 2014}

"Gente venho aqui compartilhar dessa minha alegria. Faz uns três meses que estou participando do grupo de dança do CAPS em Taguatinga (Brasília) onde realmente me encontrei... Na verdade acho que era disso que eu estava precisando, pois nunca me interessei por nada, quando se tratava de atividades físicas. Chego em casa tão cansada e em

${ }^{147}$ Rede social. 
meio a tantas coisas do dia a dia, dos afazeres domésticos, da responsabilidade de ser mãe etc. Então, isso estava mesmo era me fazendo bem, pois eu hoje estou na minha segunda noite sem medicamentos para dormir, pois o cansaço físico me ajuda a ter sono à noite. Bem, sei que estou errada e não aconselho ninguém a fazer isso, mais estou ansiosa para conversar com meu médico e falar para ele que consegui passar essas duas noites sem tomar nada para dormir. Estou feliz, pois tem mais de vinte anos que estou tomando remédio, então estou aqui para falar dessa minha alegria, pois isso nunca foi possível acontecer."

\section{ANEXO 2: TABELA DE APRESENTAÇÃO DA DANÇA CIGANA}

Tabela de apresentação do grupo Ciganos de Luz DF. 
DATA

$15 / 05 / 2014$

$07 / 07 / 2014$

$25 / 07 / 2014$

$25 / 09 / 2014$

$25 / 10 / 2014$

$28 / 11 / 2014$

29 e $30 / 11 / 2014$

$04 / 12 / 2014$

$21 / 02 / 2015$

$07 / 04 / 2015$

$16 / 04 / 2015$
LOCAL

Evento Semana da Luta Antimanicomial, Praça do Relógio, Taguatinga/DF

Evento $58^{\circ}$ Cometa Cenas na Universidade de Brasília, com a participação dos ciganos Calon Brasília/DF

Festa Junina, CAPS II, Taguatinga/DF. Evento Festa da Primavera, Instituto de Saúde Mental, Riacho Fundo/DF

Evento Galinhada da Tungra, Cruzeiro Velho/DF.

Evento Amostra Grátis, Hospital São Vicente de Paulo, Taguatinga/DF

Evento Kultur Brasil Cosmopolita, evento remunerado, Conic, Brasília/DF

Encontro em acampamento cigano Calon com transporte do CAPS, Sobradinho/DF

Evento PicNik no Hospital São Vicente de Paulo, Taguatinga/DF

Evento Quebrando Preconceito, Hospital de Base, Brasília/DF.

Evento I Semana Cultura do Instituto de Saúde Mental Instituto de Saúde Mental, Riacho Fundo 


\section{ANEXO 3: CLIPAGEM}

Matéria do Doida de Pedra no jornal Correio Braziliense, maio, 2014.
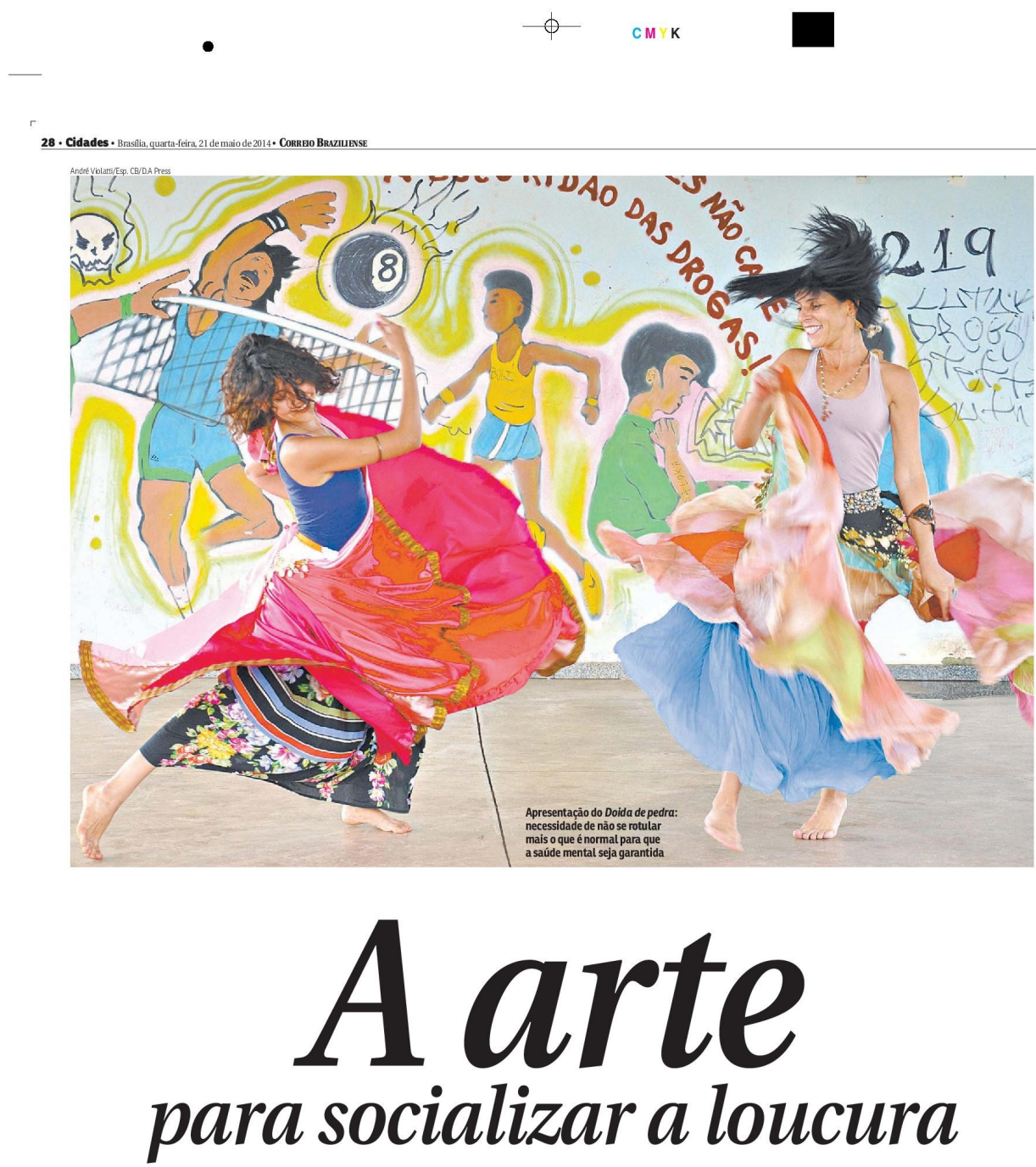

Projeto artístico abre as portas dos manicômios a fim de que os pacientes possam mostrar a produção própria àqueles que estão do lado de fora. E tenta mudar preconceitos da sociedade em relação às patologias mentais
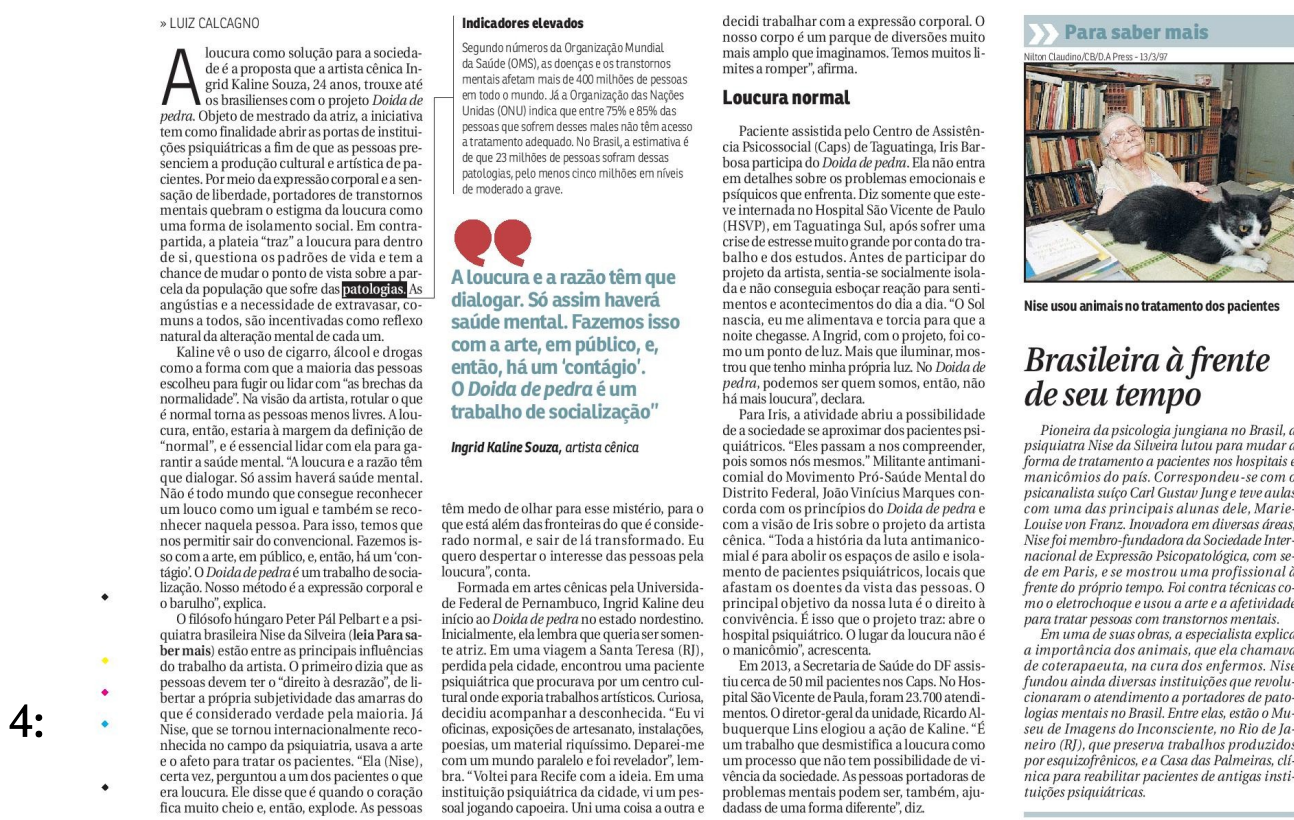

Brasileira à frente de seu tempo

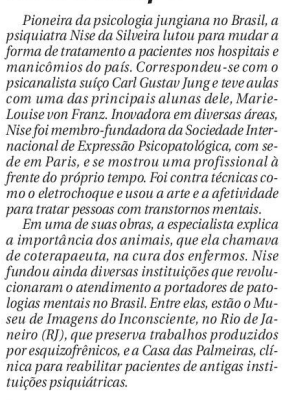




\section{ENTREVISTAS}

As entrevistas foram transcritas para esta dissertação preservando a fala original.

\section{DAIANE ROCHA}

Cigana Calon do acampamento de Sobradinho, integrante da CONJUVE - Conselho Nacional de Juventude como Conselheira de Juventude de Povos e Comunidades Tradicionais.

Entrevista concedida em Brasília, outubro de 2014

\section{Authora Desconhecida: Daiane, você poderia falar um pouco sobre o que é a dança cigana para os ciganos?}

Daiane Rocha: Meu nome é Daiane da Rocha, sou cigana Calin. Aqui no Brasil temos três etnias ciganas: Calon, Sinti e Rom. Os ciganos Calons tem uma grande expressão em nosso país por sermos em maior quantidade e por levarmos a cultura à risca, já que vivemos em barracas, usamos roupas diferentes e temos o nosso dialeto.

Uma das nossas características mais importantes é a nossa dança, é com ela que esbanjamos alegria, apesar dos preconceitos que sofremos por não termos direitos iguais. Mesmo assim lutamos, pois temos condições de conseguir o melhor para o nosso povo. Nós também somos filhos de Deus.

A dança é muito importante porque ela tem uma energia boa, nos ajudando a seguir em frente. Quando dançamos a gente consegue tirar as energias ruins e traz bons pensamentos, nos mostrando como a vida é linda. Na nossa dança usamos alguns elementos da natureza que é a água, terra, fogo e ar. Cada movimento que fazemos puxamos esta energia boa para nós.

Com a dança conseguimos levar para as pessoas não ciganas, um pouco do que temos. Quando nos apresentamos em colégios, em pontos de cultura, evento em geral, percebe-se que as pessoas passam a nos ver com outros olhos. As gadjins e gadjons, que em nossa língua significa quem não é cigano, nos dizem que tinham uma imagem diferente do nosso povo e não sabiam que a nossa cultura era tão linda, alegre e com uma dança livre. Apesar do preconceito que passamos tentamos sempre levar esta alegria. Dançar é bom para o corpo e para a alma e a dança cigana é fantástica. 
AD: O que você acha dos gadjons e gadjins quando abrem suas escolas de dança para ministrar aulas de dança cigana?

DR: Nós não temos nada contra desde que as pessoas que estão dando estas aulas não falem que são ciganas. Para a gente é muito bom porque está levando a nossa cultura para outros locais. A dança é uma das partes de nossa cultura que amamos e temos muito respeito, então pessoas não ciganas que estão ensinando nos fazem felizes, porque levam a nossa alegria para outras pessoas.

AD: O que é corpo?

DR: Corpo é a base. Ele tem que estar bem para você seguir em frente. E diga de passagem, a dança faz isso com o corpo (risos). 


\section{MARIA CLÉU}

Maria Cléu participa do grupo Ciganos de Luz DF, está na oficina de dança cigana no Centro de Atenção Psicossocial (CAPS II) como voluntária e tem um histórico de tratamento psiquiátrico. Entrevista concedida em Brasília, outubro de 2014.

\section{Authora Desconhecida: Cléu, o que vem sendo a dança cigana para você? Desde seu início com as oficinas em 2014 até hoje em dia.}

Maria Cléu: A dança cigana para mim, hoje, representa muita coisa. Antes eu tinha muita vergonha do meu corpo, hoje consigo me expressar, não só com a dança cigana como em outras áreas da minha vida, principalmente nos meus sentimentais. Também uso a dança para poder quebrar barreiras do medo, da vergonha e isso me fez abrir os olhos para novos horizontes. Passei por muitos problemas que atingiram meu corpo e com isso fui criando bloqueios. Com a dança, fui capaz de quebrar barreiras sabendo que posso viver meu corpo da forma que eu quiser. O elemento na dança que mais me identifico é o fogo. Dançar para mim é fogo.

\section{AD: O que é corpo?}

MC: Corpo é tempo. Com este tempo posso fazer o que eu quiser com o meu corpo sabendo o que é bom para mim. Posso expressar meus sentimentos de tristeza e alegria, nessa expressão posso expor o que eu quiser. Meu fogo, meu ar, minha terra, minha água. 


\section{MAIARA IORIS}

Ioris é terapeuta ocupacional do Centro de Atenção Psicossocial (CAPS II) de Taguatinga, especializada em Terapia Ocupacional na Saúde Mental e supervisora das atividades de dança cigana no CAPS II e atuante no Movimento Pró-Saúde Mental. Entrevista concedida em Brasília, novembro de 2014.

\section{Authora Desconhecida: Como se encontra hoje em dia as situações dos CAPS no DF?}

Maiara Ioris: Os CAPS no DF são bem atrasados no sentido de um trabalho intersetorial com áreas diversas. Tive a oportunidade de antes de vir para o DF, estudar em Belo Horizonte $(\mathrm{BH})$ e Porto Alegre (PoA). Em BH existem os espaços de CAPS e os Centros de Convivência, que são feitos por vários artistas e este contempla mais artistas do que profissionais de saúde. Aqui no DF existe muito pouco esta parceria com artistas. Que eu saiba tem no CAPS do Paranoá alguns músicos.

O trabalho intersetorial no DF tem muito a evoluir, porque se for para falar sobre a questão da loucura o trabalho com atividades artísticas e culturais podem e muito trazer saúde. A expressão e o reconhecer-se diante das situações, dos delírios, da tristeza, o ressignificar isso, se promove a partir da arte, das sensações. Há o trabalho na saúde mental com os profissionais da saúde e com os artistas que presenciei em minha vida profissional, que seria o trabalho interdisciplinar, ainda é pouco e quando há não existe remuneração. Eu percebo claramente a ressignificação do sofrimento pela arte e é explícito a melhora nos tratamentos. Por todo tempo de estudo e aprendizado que tive só pude perceber que com a arte existe uma maior integração do bem estar, da vida humana. É uma pena existir tão pouco esta parceria. Quando existe são eventos esporádicos com a rede ocupação cultural da FIOCRUZ.

\section{AD: Qual a maior dificuldade encontrada nos CAPS do DF? Seja pela política, aceitação de atividades pelos usuários, administração, social...}

MI: A dificuldade hoje é a questão da gestão, do funcionamento de como tem que ser feito em relação às portarias e legislações. São poucos serviços e claro que atualmente está aumentando, porém a demanda é incomparável pela quantidade de serviços oferecidos e número de habitantes. Como estou no CAPS II devemos atender por volta uma região de 200.000 habitantes e atendemos 1.300.000 habitantes. É uma quantidade imensa. São poucas pessoas trabalhando, havendo um longo espaço de espera para os usuários para conseguir a vaga. Os trabalhadores desta área são profissionais da área de 
"Psi", diferente dos outros locais que trabalhei, que tinha pedagogo, educador físico e aqui não tem. A não ser alguns voluntários.

\section{AD: Sobre o trabalho da dança cigana com os alunos do CAPS, como este trabalho vem sendo visto?}

MI: Eu vejo uma rapidez muito grande no tratamento, um fluir do contato consigo, a questão da auto-estima que é muito trabalhada, o significado social, o estar fora do CAPS, o significado que também está sendo para a família. A dança vem sendo importante pela inserção social, por estreitar os laços sociais, isso também vem devido as apresentações, que muitas aceitam e se envolvem.

O social é de extrema importância, nota-se uma melhora terapêutica fantástica. As pessoas que praticam as atividades, especialmente as mulheres, geralmente vêem com uma baixa autoestima, não tem um sentimento de carinho por si, é notável a melhora destas pelas atividades que ao se verem bem, acaba favorecendo a melhora com o outro. Por exemplo, houve uma das mulheres que ao entrar, estava para se separar, achava que era algo só do marido e após a dança aconteceu uma retomada de seus laços afetivos, já outra que possui um filho com muitos problemas de saúde, está participando conosco desde o início e o seu comprometimento mostra que ela não só cuida dele como também cuida dela.

\section{AD: O que é corpo?}

MI: É a minha percepção diante do que eu sinto, da minha imagem quando me olho no espelho, como é sentir esse corpo. Eu entendo o corpo como sentimento, se eu sinto que estou leve é como se eu tivesse uma percepção de estar leve, então meu corpo também está bem. $\mathrm{O}$ corpo é a minha percepção diante da minha imagem no momento. Se estou bem, meu corpo me acolhe bem. Essa percepção é maior do que qualquer valor de bonito e feio.

\section{AD: O que é saúde mental?}

MI: É a paz interior, independente da situação, do sofrimento. É saber que existe algo e que se pode reerguer. Entender a vida com seus altos e baixos. Ter uma qualidade de vida independente dos fatores que me assolam. A saúde não é apenas uma ausência de doença e a saúde mental não é apenas uma ausência de algum transtorno/sofrimento. 



\begin{abstract}
AMIR HADDAD
É teatrólogo, diretor, ator e está na frente do grupo teatral Grupo de Teatro Tá Na Rua Palestra durante o Ocupa Nise - IV Congresso da Universidade Popular de Arte e Ciência. Material registrado no Rio de Janeiro, setembro de 2014.
\end{abstract}

\title{
VITOR PORDEUS
}

Médico imunológico, ator, está à frente do projeto Hotel da Loucura, projeto de humanização das alas psiquiátricas do Instituto Nise da Silveira, no Rio de Janeiro.

Amir Haddad: (...) Quando mudou a política da cidade e o prefeito se estabeleceu no Rio uma coisa detestável, indescritível, chamada de Ordem Pública. Parece que a Ordem Pública é a beleza para a gente fazer tudo o que quer. Não. A Ordem Pública é para a gente fazer nada. E com esta idéia de Ordem Pública, os grupos de rua começaram a serem perseguidos. Havia uma limpeza, eles prendiam quem se beijava na rua, prendiam quem joga papel na rua, prendiam o morador de rua. Prendiam tudo que pode dar má impressão. Entre essas e outras coisas o teatro de rua estava sendo perseguido e muitas vezes com cassetetes e gás de pimenta. O tempero é outro.

Tinha uma época que a gente perguntava, e perguntava para a cidade inteira que com quantos cassetetes se faz um cidadão. Como é que se forma a cidadania? É na prisão? Na violência? Muitas vezes ainda fazemos coisas parecidas inclusive na nossa própria casa. (Paciente de outro ambulatório gritando). Eu acho maravilhoso isso, eu estou falando isso e um cara lá gritando. Olhe onde nós estamos, entende? Isso é uma conquista! Estamos iguais a bicho de goiaba. De dentro para fora. (...)

Na cidade do Rio de Janeiro existe muita criminalização do cidadão do Rio. Mas isso também em qualquer cidade do país, a população está sempre criminalizada. Chegou a dizer que o problema do Rio de Janeiro eram os cariocas que não sabiam se comportar, que quando era carnaval eles mijavam na rua. Quando os valores deles estão atuando, o próprio processo nos civiliza, nos ensina, nos faz melhores e crescermos, quando o processo está interrompido, é interrompido como é agora o processo civilizatório da sociedade ocidental, que é um processo arrebentado. Então que valor que você usa? Quando não há mais nenhum valor que possa segurar as pessoas. Ai vem um valor absoluto: A ordem. A ordem é o maior de todos e contra qual nenhum de nós que se atreva a se opor. Por que a ordem? Porque nenhum de nós é pela desordem. Uma cidade perdida é a ordem que vai regulamentar aquela cidade. Então nós 
perguntávamos: Com quantos cassetetes se faz um cidadão? Mas também perguntávamos com quantas obras de arte pública se faz um cidadão? Qual é a outra possibilidade de uma educação a uma população? Então assim a gente discutia isso, enquanto isso o gás de pimenta na cara das pessoas.

Nós, os artistas de rua da cidade do Rio de Janeiro, nos reunimos contra esse tipo de opressão que estávamos passando. Fomos as praças, no meio da Praça da Cinelândia e protestamos. Durante essa manifestação, recebemos uma ligação da antiga secretária de cultura, dizendo que queria falar comigo, então ela disse: "Vem pra cá". Eu disse que só iria depois que acabarmos esta manifestação. E eu ainda disse: “Olha a secretária de cultura está querendo falar comigo, agora ela quer falar. Tentamos, tentamos e tentamos falar com ela e ela não recebeu nosso apelo, ela nos ignorou, agora que estamos na rua, que é o nosso lugar, ela liga nos chamando". Ela ficou puta comigo, mas tem que entregar, tem que entregar na hora.

Assim que terminamos fui falar com ela, ela mal olhou na minha cara e me tratou mal, me passou pro assessor que disse que eles estavam atendendo ao nosso pedido para evitar ser contra a Ordem Pública, eles estavam fazendo um decreto para os artistas de rua. Mas decreto de quê? Que os artistas de rua são livres para se manifestar desde que faça isso, faça aquilo, faça isso. É um horror. Ai eu disse: "Não senhor, não vamos fazer isso de jeito nenhum, não aceito liberdade condicional. Eu não estou preso. Eu não sofri a ditadura, não lutei contra a ditadura, eu não perdi amigos, eu não vi tortura para ter liberdade condicional a essa altura da minha vida por uma pessoa que é membro do Partido Comunista do Brasil. Eu não posso suportar isso, esse decreto não vai entrar, nós não queremos este decreto, ou uma lei ou nada".

Brigando com a autoridade, enquanto grupos que não tinham condições, aceitavam qualquer dinheiro. Mas nós como liderança do movimento, barramos o decreto e aí em contato com o vereador que se interessou com a nossa causa apresentou nossa lei. (...) Só tem um decreto e eu não sei de cor. Alguém me lembra! Ah sim, “As manifestações

culturais de artista em espaços abertos, tais como praças, anfiteatros, lagos, ruas, independem de prévia autorização dos órgãos públicos, desde que sejam gratuitas, permita a livre influência de trânsito, permita a livre passagem de pedestres, prescindam de palco ou de grandes estruturas prévias, utilizem fonte de energia de potência máxima de $30 . . . "$ Gente nunca precisa mais do que isso, não é show de rock. "Ter a duração máxima de até 4 h. E não ter patrocínio privado que caracterize como evento privado". O que também é legal, porque quando acontece isso a própria população que está em volta abandona a gente. 
Então essas são as exigências que o vereador faz e a lei foi aprovada por unanimidade. $O$ prefeito vetou julgando a lei ser inconveniente. Então mais uma vez nos reunimos, com muitos artistas de rua e até vestimos gente de artista de rua para fingir que era e fomos para a praça com volume, fomos protestar. Aí novamente toca o telefone no meio do protesto: “Aqui é Eduardo, Eduardo Paes. Quer vir falar comigo?", eu disse: "Eu vou”. Ele disse que vetou a lei, mas não queria deixar de atender a gente e que tinha aquele decreto da Jandira que podia atender a gente. Ai eu disse: "Você está louco prefeito, mas nunca." Mas isso foi maravilhoso, pois eu estava ali na frente do gestor da minha cidade, que votei para que ele defendesse os meus interesses. Eu estava diante dele como um cidadão que sabe dos seus direitos assim como deveres. Eu falei não, não e não. Ele disse: "Fica calmo, eu faço outro decreto". Claro que não prefeito! Quem é que quer decreto? Nós temos uma lei para ser aceita. É bom quando você sabe dos seus direitos, quando você está diante de uma autoridade e esta autoridade só é autoridade para responder aos seus interesses, interesses públicos.

Eu não estava defendendo nenhum privilégio para meu grupo, mas sim para o crescimento de um movimento importante para a cidade. Fizemos então o que se chamou de Primeiro Festival Carioca de Arte Pública. Ele disse: "Eu dou o dinheiro", esperamos dois anos e saiu. Fizemos em três meses mais de 600 apresentações em quatro praças. Levantamos um material para o governo para que se tenham políticas públicas para artes públicas e não editais para grupos. Isso divide as pessoas. A lei foi aprovada, ela existe. (...)

Não é só existir a lei, mas também trabalhar para que ela seja conhecida, trabalhamos juntamente com a polícia, que precisa saber da lei. A guarda municipal não conhecia e então nos proibia, agora eles conhecem. Mas isso é uma coisa em movimento, hoje os policiais sabem muito mais sobre a arte pública. Isso tudo nos faz perceber qual o papel e importância no mundo, nos encontros, nas celebrações, de que maneira podemos criar e provocar encontros que nos façam crescer que não nos condene ao isolamento vil, sem contato com o mundo, cada um fechado em si e de repente essa proposta de trazer o que é privado ao público. (...)

Nós viemos dos macacões, lá de antes, nós somos descendentes daquele macaco que pintou na caverna o Mastodonte, é dele que a gente vem, enquanto os outros iam caçar o macaco ficava pintando lá. Eles traíram a confiança da tribo, e eles diziam: "Ah seu mariquinha, vai trabalhar, vai ficar desenhando? Quero ver não te dou um pedaço do meu jacaré, fíca aí desenhando. Para que serve essa merda? Para quê?” Ninguém sabe aquele que foi lá caçar, mas o cara que pintou todo mundo sabe, está vivo até hoje. Ele não falou : “Ah vou cortar 
essa pedra, vou levar pra uma galeria e vou vender". Ele não fez isso, ele largou lá o que ele fez, ele não vendeu a pedra dele. Maluco podia vender...

Então ele deixou para usufruto dos outros.

Tudo que for para uso do avanço do coletivo, em grupo é público, é um serviço que pode ser utilizado por toda a população. É utilidade, é pública. O que nós fazemos é utilidade pública. É necessário e essencial para todos e todas as idades. Não podemos achar que somos apenas artistas, porque os artistas a burguesia já comeu, já mastigou e já está cuspindo. Na sua natureza já nasce público, arte é obra pública feita por particular. Não é o poder público que faz e determina, é a necessidade do cidadão diante do mundo que ele vive diante das confusões dentro dele que ele manifesta por outro, que ele organiza a sua desordem para o outro e que ajuda o mundo a se organizar também.

No momento que isso vira produto só quem tem acesso é quem tem dinheiro. Estamos fazendo uma perversão gigantesca eliminando a grande maioria da população, a não ter outro rito que não o evangélico. Temos que oferecer um teatro de qualidade, temos que oferecer formas de organização ritualística que não seja apenas das religiões. Nós somos celebrantes de outro ofício. O que fazemos é propriedade pública, é de todos. Esse homem que pintou o bicho nas cavernas ele tinha sangue "O" o primeiro sangue do mundo é sangue "O". Todos os macacões que começaram a se entender tinha sangue "O", o sangue "O" é doador universal. $\mathrm{Na}$ origem somos todos doadores universais.

Quando retomamos os espaços públicos e a possibilidade de dialogar de maneira horizontal estamos recuperando o sangue "O" da humanidade. (...) A teoria vem depois da prática. Nós praticamos o que nos faz ter muita possibilidade de reflexão. Muitos podem não ter pensado o porquê de ir para a rua. Fazer o que lá? Não é normal. Não é assim que se aprende. Não é assim que somos ensinados. Não é para ir para a rua, porque tem lugar para se fazer as coisas. Isso que você quer faz é ali, isso outro é aqui. Ninguém vai se misturar. Cada coisa no seu lugar. A sociedade trabalha assim. (Cantando "Esta tudo em seu lugar, graças a Deus. Não devemos esquecer de dizer graças a Deus"). E foi estabelecido essa ordem, a ordem divina. Faca com faca, garfo com garfo, homem com homem, mulher com mulher. (...) (Paciente intervém) Quando vamos a praça é sempre assim é doação total, é assim que a gente faz. Peito aberto afeto escancarado. Essa é condição do artista popular, se oferecer em praça pública. Peito aberto e afeto escancarado. Porque é ali que essa doação se estabelece. Devemos abrir nosso corpo porque é diferente estar em praça e nos espaços fechados que a sociedade 
determinou que devemos ir. (...)

\section{VITOR PORDEUS}

Vitor Pordeus: É o momento nosso, da gente aprender junto, desconstruir. O Zé Pacheco fala que nós temos que aprender a desaprender e a aprender a desobedecer e aprender um monte de coisa que a gente não aprendeu a desaprender. Nós estamos vivendo aqui um momento de mobilidade corporal de mobilidade das idéias, de mobilidade dos afetos. Dessa arte pública, dessa saúde pública possível. Psique em grego quer dizer espírito e yatros em grego curador. Então psiquiatria é curador do espírito, estamos aqui para curar os nossos espíritos, para curar nossa alma, nosso afetos, para repensar o nosso mundo, repensar nossa cultura. É importante que a gente possa aprender a dialogar, servir a natureza o espelho, ao ridículo sua imagem, a virtude sua expressão, cada época sua geração, sua forma e símbolo diz o Shakespeare. Então isso é o dialogar é servir de espelho um dos outros.

Nós estamos em um tipo de controle, onde não se admite diferença, onde não se admite estado alterado de consciência, onde não se admite nenhum tipo de divergência de comportamento e vai se homogeneizando. E a medicina, que é essa força fundamental da colonização do corpo que diz a você que se você não tomar o remédio você vai morrer. E você morre. Que encarcera pessoas em espaços fechados, que usa de força de camisa química para principal forma de tratamento, quer dizer além da colonização policial do espaço público da cidade, nós temos uma colonização farmacêutica violenta. Quando a coletividade se une, a gente está fazendo saúde pública.

A: Nós somos a desordem. Quando vamos para as ruas nós causamos a desordem, quando qualquer um que está aqui resolveu ir para rua está se trazendo a semente da desordem. Estão nos associando aos vagabundos de todas as espécies, aos vadios de todas as espécies, aqueles que morrem de fome, mas não aceitam o sistema que viveram. Muitos moradores de rua estão na rua porque escolheram a rua! Pagam caro por esta liberdade e nós somos os que viemos depois deles, escolhemos a rua também. Escolhemos a rua como sobrevivência.

Quando estamos na rua, pelo menos com o meu grupo, o que junta primeiro são os moradores de rua, nossos pares, jamais chamamos a polícia para se aliar a praça que vamos trabalhar, para levar os bêbados os loucos e viciados para hospícios (...). Quando nós nos enlouquecemos por dentro e temos que comunicar aquilo que está dentro da gente e não sabemos o que é para poder organizar novamente nosso mundo nós produzimos coisas a partir 
desta desordem interior.

A arte é a nossa maneira de organização da nossa desordem. Não é a minha ordem que manifesta a minha forma artística. Eu só consegui a liberdade quando perdi o medo da desordem. Só consegui me reordenar quando perdi o medo da desordem. (...) 


\section{VITOR PORDEUS}

Médico imunológico, ator, encabeça o projeto Hotel da Loucura. Projeto de humanização das alas psiquiátricas do Instituto Nise da Silveira, no Rio de Janeiro.

Ocupa Nise - IV Congresso da Universidade Popular de Arte e Ciência.

Entrevista concedida no Rio de Janeiro, setembro de 2014.

\section{Authora Desconhecida: O que é corpo?}

Vitor Pordeus: Ah, essa pergunta o que é corpo... E o que pode um corpo? O que Espinoza pergunta no livro a Ética na parte III, o que é a origem e natureza dos afetos. O que é o afeto? E o que é o corpo dentro do afeto? Como venho da imunologia sei que o nosso corpo, em pesquisa, tem $95 \%$ das células como bactérias e 5\% das células são células eucariontes, que tem núcleo individualizado. $95 \%$ do nosso corpo é bactéria, que quando a nossa mãe caga a gente né? Que deveria ser pelo parto normal, ela vive com a gente um tempo interior. Vivemos em um corpo de bactéria. Esse planeta é de bactéria. Se um alienígena viesse, olhasse de fora a Terra e analisasse viria um monte de bactéria que se mexe pra lá e pra cá. Então nosso corpo é um corpo de relações de bactérias, ecossistemas, um corpo de constante troca, constante modificação, a cada dois anos todas as moléculas do nosso corpo estão substituídas, então a cada dois anos você está completamente novo daquilo que você era, como um rio que muda o tempo inteiro, mas conserva alguma coisa.

Esse corpo é um corpo de uma mudança permanente e que permanece também alguma constante, que conserva alguma relação de se estar vivo. Que é uma relação de se auto montar, auto produzir, uma relação autopoiética. Esse corpo é um corpo autopoiético. E que a dureza, a rigidez, a falta de se movimentar é a doença. Esse corpo não é individual, porque precisamos do meio, nos alimentamos do meio, então nós nunca fomos indivíduos. Você não consegue dizer onde começa e onde termina o corpo, ao contrário, a gente vê que o corpo está em continuidade com tudo que é vivo com o planeta inteiro, com a Gaia e o sistema vivo todo. O corpo é planetário de uma só união e unidade, que está vivo e que é a única coisa viva que conhecemos neste infinito universo. O corpo é essa biosfera, estamos conectados as bactérias do Japão, o Japão está conectado ao nosso ar e o aquecimento global esta aí para nos lembrar isso.

\section{AD: O que é saúde mental?}


VP: O que é saúde? E o que é mente? Que é impossível de responder. O Maturana tem um artigo que fala: A mente não está no cérebro. A mente está na relação. Nesta relação permanente que o vivemos, o mundo muda com o bicho, o bicho muda com mundo, em relação imanente. Tudo junto. Saúde mental é relação, é estar refletindo a si próprio, estar exercitando a criatividade na relação, é estar em potência máxima da mente e do corpo. Da mente barra corpo, porque nessa concepção que temos não dá para separar a mente do corpo, o corpo é a mente em relação e a mente é o corpo em relação. A relação que é fundamental. E o Espinoza fala isso né? Que a potência máxima da mente e do corpo se alcança pela via do criativo, do conhecimento, da aquisição de conhecimento adequado com a natureza, com Deus.

Esse corpo, que estamos falando, conectado a biosfera é o que chamamos de Deus, é uma experiência da totalidade. É muito legal, porque você vê que a saúde mental é um estado de potência, de criatividade, de conhecimento, de movimento, de fluxo de afetos, que é o espetáculo. A saúde mental é o espetáculo que é a elevação dos afetos e sua ação coletiva. Vejo muito isso, a minha saúde mental eu consegui estabilizar quando consegui entrar pro teatro e comecei a fazer os rituais que foram organizando os meus pensamentos, depois com o candomblé que me ajudou a entender esta relação de nós e de nós com a natureza.

A nossa sociedade fala tanto em saúde mental, mas não consegue ter saúde mental. A sociedade dos ancestrais não fala em saúde mental, mas tem rituais que organizam este processo. É uma pergunta muito difícil de responder, muito confusa, subjetiva. Mas eu acho que é isso, a idéia de que nosso sistema nervoso central é fechado sobre si próprio e que a gente recebe perturbações do mundo exterior e organiza essas perturbações com um circuito interno dos neurônios. O próprio organismo é isso, são células que se organizam e que se substitui, se organizam, se conservam, nessa relação autopoiética. Eu não consigo ver saúde mental fora de uma coletividade. Você adoece na coletividade, você se cura na coletividade 


\section{GINA FERREIRA}

É psicóloga, trabalhou com Nise da Silveira, Ronald Laing e Lygia Clark.

Aula particular a respeito da obra de Lygia Clark, durante o Ocupa Nise - IV Congresso da Universidade Popular de Arte e Ciência. Material registrado no Rio de Janeiro, setembro 2014.

Gina Ferreira: Aqui estão as pinturas da Lygia, antes dela chegar ao neoconcreto. De uma pintura belíssima de várias perspectivas, não sendo apenas concreto, se tem várias formas de ser percebido, você olha daqui vê um ângulo, dali outro, você pode dizer que vê vários desenhos ao mesmo tempo, tendo uma unidade. Porque eu gosto de pensar a arte como um exercício pro pensamento para quem lida com a psicose. Porque se você pensar, não é bem isso? Você tem um ângulo de visão do mundo e o outro tem outro e nisso pode se entender e formar uma opinião que dê unidade. Olhando de formas múltiplas.

Tem uma da teoria da complexidade que é o seguinte: para um sujeito normal ele fala que existe uns fractais. Vou sair da Lygia agora para vocês pensarem em outras coisas. Os fractais são fragmentos, que nem o caleidoscópio, o psicótico ele não vê. A visão de mundo é fragmentada e não pertence a uma unidade de mundo entende? $\mathrm{O}$ mundo é só aquele fragmento. Não são vários fragmentos que se juntam. Por isso que quando falo que a oficina tem que ter um alinhamento é porque se ele pensar na terça e estiver na quinta-feira e ele se lembrar da oficina, a oficina tem que estar de imediato para ele. O mundo é aquela oficina que ele está pensando naquele momento. Então ele não consegue pensar que só daqui a não sei quantos dias, da outra semana, que vai ser terça e vai ter oficina. É demais para quem ver o mundo todo partido. Uma oficina que funciona hoje e só depois quando ela quiser não é terapêutica.

Voltando para ela. A Lygia começou com o concretismo. Se você olhar este quadro, você vai entender o construtivismo, de um movimento ela parte outro movimento que daqui ela tira outro, que ela pode tirar outro e voltar para aqui para este mesmo desenho. Construtivismo é quando você vai desdobrando. Tem um russo muito anterior a ela que se espelhava muito e se chama Malevich.

Ela vai trabalhar então com a questão da superfície, vai trabalhar com as linhas para preencher o vazio do quadro, entrando no neoconcretismo (desenha em um papel traços e cortes para o encaixe do quadro), a linha era o corte, mas não se via o corte. Quando você vê um quadro 
sem moldura, ele e a parede são um só, isso se chama de quebra da moldura. Esses são uns desenhos de maquetes que ela fez, você tem a impressão que tem um relevo aqui não é? Mas não tem. Ela une. Você pode não perceber que são duas estruturas unidas e acaba achando que é nanquim. Então ela corta e junta ficando unido. Ela não pensava em fazer a Estruturação do Self... Olha, quebrar e unir. Mas ela vai chegar lá.

Bom depois que ela faz isso, ela começa a fazer os Bichos que são de aço. Ela faz dobras como se fosse dobra de papel e encaixa um no outro, o outro no outro, e deixa ali, você pode pegar dobrar e fazer vários planos. Nesse momento ela não está mais ali é você com o objeto, aí você vai ter outras percepções e sentidos. Já não existe uma única forma. E tem uma explicação muito simples que falo para os alunos da Angel Vianna, para que entendam o que é o neoconcretismo. Numa dessas, ela estava dando aula na Sorbonne e deu o título da aula de Nostalgia do Corpo, começou a criar alguns objetos, assim um suporte que coloca inclinado no bico de uma pedra, aí quando faz um movimento a pedra expulsa, mas não cai, você fica observando aquilo e aproxima do seu corpo, você fica interiorizado e sentindo isso. Ele pode despertar sensações e é a sensação que interessava a Lygia, não o objeto.

É neoconcreto porque o objeto vai ter uma subjetividade, é quando você tem várias sensações. Um objeto relacional da Lygia tem diversas interpretações e sensações para uma pessoa. $\mathrm{O}$ objeto não interessa, ela diz que o que a interessa é o Ato. Não quando você deixa o saquinho no corpo, o Ato que interessa a ela é imanente não é permanente, porque cada vê que você faz sente coisas diferentes. E olhe, que ela não tinha chegado ainda na Estruturação do Self. Ela cria os Objetos Relacionais, antes da Estruturação do Self, e cria por conta da Sorbonne.

Olha aqui as máscaras, elas têm um peso, têm pedras que te puxam para baixo e você tem que fazer o equilíbrio. Aqui olha, um saco de feira e bota um peso aqui, um outro peso aqui e o sujeito tem que tentar o equilíbrio. Ela criou 1000 objetos. Esse é um jogo maravilhoso para uma aula de expressão corporal, são aquelas luvas de lavar pratos com

bolinhas de borracha de golf. Você pega a bolinha com a luva e fica com ela, você vai sentir o peso da bola, depois de um tempo você pega sem a luva, então é diferente o tato. Tem um plano de imanência, é quando você tem gestos e movimentos com teu corpo que você não percebe. Você sabe que faz algo, mas não percebe que o corpo faz.

Só tem o pensamento, você não dá bola, só vai dar bola pro corpo quando sentir dor. Dor no dedo, ai você vê que tem dedo e dá importância. Por isso que friso que tem que ter aulas de expressão corporal, fazer com que o sujeito sinta o pé, a perna, relaxe, contraia e expanda, 
porque depois se entrega a dança de corpo, não só eles, assim como nós. Temos o pensamento e a ação. Tem gente que não tem distância entre o pensamento e a ação. Deu vontade de dar porrada, deu porrada. Algumas pessoas têm o corpo anulado, dor e pensamento, não tem coerência entre corpo e pensamento.

Nós temos uma colega assim que faz ashiajshasuhusahshaha e depois sai, tem que ter paciência e humor para lidar com isso. Ela lida assim não só nas casas terapêuticas, mas em sua vida. A Lygia criava porque era artista, é arte. Alguns dizem que a arte não enche a barriga de um paciente. E sim, precisam de mil e outras coisas, precisam acima de tudo de justiça social, mas se a gente gosta da arte por que eles também não vão gostar? Ela tem $O$ Eu e o Tu, é uma roupa com máscaras, que tem um emborrachado bem grosso, ai você se veste com ela, no $E u$ tem palha, no Tu tem dois seios, eu experimento e ele tateia, ele se reconhece em mim e eu nele. Mas você vê que o que interessa nela, é o Ato.

Tem um que ela chamava de a Fantasmática do Corpo, tem um capítulo do livro da Gisela Pankow que ela fala de parte do corpo que sentimos e que não existe, exemplo: Quando alguém amputa a perna e ainda a sente, é a sensação do teu corpo, do corpo que você viveu, de uma sensação que você viveu e ficou o fantasma. Na Estruturação do Self, se você deixar o saquinho em algum membro, depois que ficar bem relaxado a sua interioridade não vai perceber mais que aquele saquinho não está mais, porque teu corpo engoliu aquele saquinho, isso ela chama de Dentro e Fora, o teu corpo vai despertar uma memória do corpo, o que chamava de Vivências do Pré-Verbal. Pode te despertar uma sensação que te lembra o jeito que tua mãe te pegava no colo, ou seja, de um corpo que não tem mais, isso é a Fantasmática do Corpo, que não é mais o mesmo corpo, mesmo que você sinta a sensação, mas não lembra o que é.

Aqui tem a Baba Antropofágica, linhas na boca e vai puxando a linha e coloca no corpo do que está deitado. A Lygia quando fazia terapia ela não falava nada e ai ela começou a babar, quando o seu terapeuta o Pierre Fédida, dizia: "Baba Lygia, baba", foi ai que ela criou. Ela nunca chamou o seu trabalho de performance e sim de vivência, ela dizia que a performance é um espetáculo que o de fora vê sem participar a vivência não, você experimenta. A Cabeça Coletiva, esse aqui é uma performance que ela fez.

Aqui começa a Estruturação do Self, ela volta para o Brasil e monta um consultório, resolveu 
fazer o Sapir ${ }^{148}$, depois começou a usar os objetos e viu que eles tinham muito mais efeito do que o Sapir. Até o Caetano Veloso já fez com ela, mas fez poucas sessões. Nos objetos ela coloca as conchas, os sacos pesados, para falar as sensações do que está se passando. Eu faço em uma menina que me diz: "Ai, estou relaxada", mas ela não entrou nos objetos. Quando ela não sente mais os objetos ai ela entrou. A pessoa já deita no colchão de bolinhas de isopor. Sempre a pedra na mão para não sair da realidade. Tem relatos de pessoas que falam como se estivessem espatifados por dentro. A intenção na verdade é dividir e depois quando você passa o outro saquinho por cima rejunta, é uma reestruturação do self, porque não é o eu social é um eu que passa a se conhecer, um eu que não conhece inteiro, então esse eu que é um outro corpo, que na realidade ela não chegou a dizer isso, mas acredito que seja, o que se quer é esse outro.

Eu tive um caso que será publicado na Angel. Um rapaz que fez a Estruturação do Self e respondeu pouco, ele tinha vinte e poucos anos quando aconteceu. Era um paranóide, dizia que estavam gravando ele, que entravam e colocam bobs no cabelo dele, o pensamento dele gravava o pensamento dele. Comecei a tratar dele ouvindo bem o que ele estava me trazendo. Um dia o pai dele me ligou dizendo que ele ia a um terreiro de candomblé. Acontece que o pai de santo não entendia que as coisas para um psicótico se tornam concretas, então dizer que ágüem fez um trabalho para você é de enlouquecer.

Ele participava dos trabalhos e voltava muito mal, o pai de santo falou que ele era filho de Obaluaê e nesse dia o pai dele me ligou dizendo que ele tinha tentado matar a mãe na cozinha e que eles prenderam o rapaz no pé da mesa da cozinha. O menino só chamava por mim querendo me ver e ele se negava a tomar o remédio. Quando cheguei lá ele estava com uma tira e uma toalha amarrada, estava com outros panos amarrados, parecia mesmo o Obaluaê. Estava deitado, então eu deitei ao lado dele e levei a pedra, perguntei se ele gostaria de segurar a pedra e ele disse que sim. Me contou que ele era o Obaluaê, eu disse: "Sim, mas esse corpo é do Hamlet ${ }^{149}$ e ele é dono de si, dono desse corpo. Como eu vejo seu corpo você é o Hamlet". E segurou a pedra, eu fiquei com ele até ficar mais calmo, sempre repetindo que ele era o Hamlet. $\mathrm{O}$ acariciei e perguntei se poderia falar com o psiquiatra para ele tomar um medicamento e ele deixou. Ele foi desamarrado, me abraçou e ficou com os pais.

No outro dia ele foi para o consultório e me disse: "Sabe o que eu queria mesmo? Era sair do

\footnotetext{
${ }^{148}$ Edward Sapir.

${ }^{149}$ Os nomes de pacientes são substituídos por personagens de teatro.
} 
meu corpo e me ver". Eu tinha dito que o corpo era dele não é? Respondi que não é impossível. Não tinha aquela máquina que tirava 72 fotos? Então combinamos que no outro dia iríamos tirar 72 fotos de parte do corpo dele, eu pedi a um amigo, que era fotógrafo para nos receber. As fotos foram tiradas, fomos para o estúdio do meu amigo que revelou as fotos, parte por parte. Voltamos pro consultório e juntamos as partes. Cessou os delírios. Voltamos a fazer a Estruturação do Self e ele respondia muito pouco, mas no último dia de sessão ele sentou olhou para mim e disse: "Eu sinto um vazio muito grande, aqui dentro, mas quando olho nos seus olhos eu vejo que sou capaz de amar". Ali era o corpo respondendo, o outro existia e podia ser parte dele.

Passaram dois anos e não o vi mais. O encontrei no Flamengo por acaso e o chamei para tomar um café. Ele estava noivo e tinha voltado a estudar. Perguntei se ele estava feliz e ele disse: "Eu estou bem". Ele ficou desse jeito porque na verdade teve relações com a irmã, ele não aguentou essa barra, pirou porque quando ele parou, foi colocado um limite de não querer mais, ele gostava dela e não aguentou a culpa. Conviver com isso é uma paranoia, ninguém podia saber. 


\section{LULA WANDERLEY}

Médico, artista gráfico, atua no Instituto Nise da Silveira, antigo Hospital Dom Pedro II, com o Espaço Aberto ao Tempo (EAT). Trabalhou com Nise da Silveira, Lygia Clark, faz aplicação da Estruturação do Self em clientes do EAT e é esposo de Gina Ferreira.

Ocupa Nise - IV Congresso da Universidade Popular de Arte e Ciência. Entrevista concedida em setembro de 2014.

Authora Desconhecida: Lula você pode falar um pouco sobre o seu trabalho?

Lula Wanderley: Eu trabalho com corpo e saúde mental há muitos anos e durante muito tempo, por 8 anos, eu tinha escrito algumas coisas sobre o corpo, mas quando eu trabalhava com a Nise. Ela se interessava muito nisso. Veio a Lygia Clark, me aproximei dela e fiquei estudando com ela as questões do corpo. Se você coloca uma toalha molhada no seu ombro da pra você delinear a forma dela, pela sensação de superfície do corpo, mas Lygia criou uns objetos que não são de superfície. A sensação, é uma matéria que corre pelo interior, sendo assim, não dá pra você recompor ela pela visão. Os objetos abrem seu corpo para um espaço imaginário do interior do corpo com objetos que são incorporados ao corpo e criando uma unidade. Percebi nas pessoas que tem problemas psíquicos muito graves, descontinuidade na vivência do corpo, vazio, buraco, os objetos preenchem criando uma totalidade.

\section{AD: Os locais deste vazio, você já sabe onde existia?}

LW: Não, não, era pela vivência com a pessoa. Essa totalidade ela trazia a tona, uma totalidade que temos e que a vida contemporânea nos leva a esquecermos que temos, ela trazia essa totalidade organizada que temos com o mundo. É muito complicado porque é uma relação com o todo e a parte que no paciente é quebrada. Então eu toco o corpo dele e restaura essa unidade, ajuda a sair um pouco da psicose, não é assim uma coisa que tem cura, é uma experiência não verbal, que termina lhe dando certa estruturação melhor para se defender da psicose.

Esse é um trabalho que cheguei, não foi um caminho da Lygia. Cheguei quase que acidentalmente. Uma vez me pediram ajuda com uma pessoa psicótica, ela andava muito devagar e trabalhava em um banco. Notou-se que estava totalmente introvertido e o médico mandou para internar. Me pediram para falar com ele, só que ele não falava nada, é meio o que a gente chama de catatonia. Ele andava com a distância de um dedo do pé, a família que o carregava. Ai eu disse: "Não precisa disso, abre a porta do carro e deixe ele andar", ele 
passava umas duas horas para chegar, mas respeitei completamente, e via se ele conseguia se identificar comigo. Foi então que eu disse:

"Olha eu também sei andar que nem você". O convidei para dançar no centro comercial do Rio e nós fomos andando extremamente devagar, foi uma confusão, porque as pessoas viam e me xingavam, porque estávamos atrapalhando. Teve uma senhora que chegou e disse: "Eu sei que você pode andar normal, porque você não o leva no colo?" eu disse: "Vá tomar no cú a senhora", e nisso ele gostava que só. Ele foi criando uma relação comigo.

Eu tinha na minha sala um monte de Objetos Relacionais, porque fazia experimentos com artistas, um dia ele chegou pegou um objeto daquele e colocou no pé, ai em outro dia ele chegou pegou mais de um objeto e colocou no pé. Eu comecei a criar jogos com aqueles objetos e fui envolvendo o corpo todo, tirei ele daquele estado. Ele começou a escrever cartas, pra todo mundo.

\section{AD: Mas ele já estava verbalizando?}

LW: Escrevia e verbalizava também, mas não era muita coisa. Escrevia me odiando, dizendo que tinha tirado ele de um estado de um encontro com Deus. $\mathrm{Na}$ medida em que ele foi melhorando a fluidez verbal, eu soube da história do surto. Ele estava trabalhando no banco e no corre corre ele teve um sonho com uma grande árvore, chegando ao banco ele fez um poema sobre a árvore, daí ele teve a idéia de andar devagar porque era um comunicação diferente com o mundo e com Deus. Ele vivia uma metamorfose em árvore, uma dissolução cósmica que a aquela árvore era um universo e aqueles objetos tinham uma linguagem que adentrava e ganhava um significado simbólico, quando ele foi dando significado ele foi saindo da psicose. Foi aí, que comecei a usar nos pacientes psicóticos. Eu não uso como Lygia usava, o trabalho dela é uma linguagem, eu transfiro para meu foco. Teve uma época que vieram muitos intelectuais aqui, inclusive psicanalistas que viram o trabalho que fazia, ainda no Museu da Imagem do Inconsciente e me chamou para trabalhar com eles. Chegado no auge do trabalho, ainda tendo resquícios do regime da ditadura, todo mundo saiu e eu não tinha saído porque quem tinha me colocado ali foi Nise, só que fui punido sem ter lugar para trabalhar, ai uma senhora me pegou e me levou para trabalhar com ela, uma cristã que ficou com pena de mim e tal, era uma enfermaria psiquiátrica. Então eu tinha uma experiência com a Lygia, outra com a Nise e para o final da década de 80 foi fechando aquela enfermaria e abrindo o Espaço Aberto Ao Tempo (EAT).

\section{AD: Tinha apoio governamental o EAT?}


LW: Não, esse prédio que estamos era abandonado e ocupamos.

\section{AD: Demorou quanto tempo para ser reconhecido pela Instituição?}

LW: No Rio de Janeiro demorou um bom tempo, o negócio é que o foco estava em São Paulo com a ocupação do Anchieta em Santos, a criação do primeiro CAPS. O pessoal de São Paulo que viu esse trabalho que eu fazia foi bacana, porque possibilitou alguns intercâmbios. Tem um livro chamado Reabilitação Psicossocial no Brasil, que faz um apanhando de trabalhos naquela época, no início da reforma psiquiátrica brasileira.

\section{AD: Com o tempo o hospital agregou o EAT para dentro? O institucionalizou?}

LW: Não ao contrário, com o tempo o EAT teve independência, apesar de estar aqui dentro ${ }^{150}$. Quando você tem um serviço feito pelos funcionários não pela secretaria de saúde ou por um diretor do hospital você fica com uma marginalidade grande, hoje em dia somos reconhecidos. Veio do EAT a ideia de fragmentar o hospital, por exemplo pega um serviço $\mathrm{x}$ coloca fora e vira um CAPS, então daqui de dentro saíram uns 4 CAPS, alugamos uma casa e colocamos lá fora, eu nunca consegui sair. Quero uma sede, sempre tentei sair.

\section{AD: É falta de incentivo para que não saia?}

LW: Falta de ação política. Porque se o diretor cria uma unidade e bota um diretor, é mais fácil ele sair do cargo. Ele não pode colocar um diretor aqui porque esse serviço é mais privado do que público. Ai o pessoal faz: "Ah deixa o Lula trabalhar lá" e é isso. Não faz parte de uma rede. Agora que a gente está tentando entrar nessa rede. Eu sou de Recife, onde trabalhei muito como artista plástico. Fiz um curso médico, mas não exerci a profíssão. Não sou da psiquiatria, mas era da psiquiatria no sentindo de que eu poderia dar um plantão porque tive experiências na Tamarineira ${ }^{151}$. Vim passar um mês aqui e conheci a Nise e ela então cismou que eu deveria trabalhar com ela.

\section{AD: Você a conheceu porque a procurou?}

LW: Não, não. Eu tinha um vizinho que me perguntou se eu queria conhecer a Nise. Era um poeta... (entra um cliente). Eu fui para a Casa das Palmeiras trabalhar com a Nise. Como tinha experiência com teatro fizemos um grupo, depois vim para o $\mathrm{Museu}^{152}$, foi quando fui

\footnotetext{
${ }^{150}$ O EAT encontra-se dentro do Instituto Nise da Silveira no Rio de Janeiro, próximo ao Museu do Imagem do Inconsciente, Hotel da Loucura, Loucura Suburbana e alas de pacientes crônicos.

${ }^{151}$ Nome popular para o Hospital Ulysses Pernambucano. Também conhecido como Tamarineira, nome do bairro localizado em Pernambuco.

${ }^{152}$ Museu da Imagem do Inconsciente, RJ.
} 
trabalhar em algo maior. Mas veja, não me interessa ser um artista dentro da saúde mental, nem me interessa ser um psiquiatra dentro da saúde mental, entre arte e saúde mental eu prefiro ser o "E" uma conjunção gramatical. Eu queria fazer uma saúde mental poética, é diferente. Tratar poeticamente os casos. Lidar com o sofrimento do outro poeticamente. Por isso não trabalho com psiquismo, não trabalho com biologia, trabalho com comunicação. Não trabalho para transformar alguém em artista, para eu fazer arte, eu trabalho com poiésis, criação de linguagens, eu crio linguagens, a partir do princípio que todo sofrimento intenso é um corte de comunicação com o outro.

O corpo é uma linguagem e uma coisa difícil das pessoas entenderem, qual é a posição do "E”. Eu disse a Nise, que não sei se iria aceitar o seu pedido porque sou incapaz de ler um livro de psiquiatria, então ela disse: "Não. Utilize sua sensibilidade como instrumento de trabalho. E o jeito de utilizar este instrumento é ir ao encontro do sujeito sem teoria nenhuma. Pegue as impressões que ele te causa e dê respostas a ela através de propostas, criações, linguagens. Através da expressão sua e dele”. Até que eu precisei de um lugar para fazer isso porque não posso fazer em qualquer canto. $E$ isso foi tão contundente que acabamos com uma enfermaria psiquiátrica sem nenhum ato burocrático. Porque ela simplesmente perdeu o sentido.

\section{AD: Quem visualizou esta perda de sentido?}

LW: Porque é assim, o que chamo de EAT é você voltar com os gestos cotidianos, a enfermaria é um lugar que não há gestos, a condensação do espaço é tão grande que o espaço vira uma cama. Você trazer a tona, reconstruir novamente o significado de um gesto comum dentro de uma enfermaria, cria-se uma pluralidade de vivências, maneiras de relacionamento diferentes. A enfermaria como é vista pelo psiquiatra não é assim. Então o hospital nos deu licença para acabar. Mesmo quando era enfermaria tinha vida ali, tinha cinema, tinha teatro, tinha uma significação grande de qualquer coisa. Quando estávamos próximos a sair, compramos tinta e pintamos tudo aqui. Só não pintou o teto porque não tínhamos mais tinta, mas tudo se pintou, porta, janela... Essa enfermaria não existe mais foi quando viemos para cá.

Eu costumo ficar atento aos talentos que tem aqui e temos uma grande vontade de fazer um grande grupo que invada a cidade. Já tivemos um grupo aqui de performance chamado $O$ Prazer é Todo Meu, quando fizeram o de música juntamos os dois e criamos o grupo de ações poéticas Sistema Nervoso Alterado. Que é um grupo de música/performance e nos 
apresentamos.

\section{AD: Se apresenta levando o nome do CAPS? Ou do grupo?}

LW: Do grupo.

\section{AD: Então quem assiste não sabe a origem do grupo?}

LW: Esse grupo tem um vizinho que é músico, tem o sobrinho de um paciente que é músico de estúdio, um cara de teatro e fazemos assim espetáculos complexos. Horas de ensaios. Tínhamos um chamado A Camisa de Força Social e de tanto se apresentar partimos para outra coisa que é Coração Em Desatino, que é um musical, com coro grego, rapper, cantor nordestino. Narra a história da reforma psiquiátrica em linguagem de cordel. Já abrimos um show do Paralamas do Sucesso e da Pitty em Salvador. Abrimos o espetáculo com Paulo Bruscky fazendo o Eletroencefalograma e uma música de Hermeto Pascoal, ai dá um estouro e diz: "Se você está nervosa, irritado, dando bico no cachorro, brigando com a patroa é porque você está com o Sistema Nervoso Alterado!". Ai vinha uma entrevista da Madonna que ela deu para o $\mathrm{BBC}^{153}$ dizendo que nos conheceu na feira da Madureira e que adorava o nosso grupo.

\section{AD: O Harmonia Enlouquece é daqui também?}

LW: Não o Harmonia é do CPRJ ${ }^{154}$ Eles são um grupo de música e nós somos um grupo de performance e começamos praticamente juntos. Quando você vê os primeiros vídeos vai ver que era algo mais rebuscado, era da saúde mental e saúde mental não tem vocação para cultura, a não ser que você assalte a saúde mental e faça um trabalho. Mas de dentro mesmo não tem.

Quando a gente se apresenta via Ministério da Cultura é maravilhoso via Secretaria de Saúde é horrível, não sensibiliza. Ao mesmo tempo que estou dentro deste espaço da saúde mental eu também estou fora.

\footnotetext{
${ }^{153}$ Canal de televisão British Broadcasting Corporation.

${ }^{154}$ Centro Psiquiátrico Rio de Janeiro.
} 


\section{THIAGO PETRA}

Psicólogo, direção da Ong Inverso e integra o colegiado do Movimento Pró-Saúde Mental. Entrevista concedida em Brasília, fevereiro de 2014

\section{Authora Desconhecida: Qual a situação do DF a respeito da saúde mental? Como você vê a atuação da política para a saúde mental?}

Thiago Petra: Brasília é marcada por longos períodos de administração de direita. Direita no sentido conservador da palavra, não sei se existe mais essa coisa de direita e esquerda. Brasília foi uma cidade planejada onde o primeiro governador foi nomeado, então não teve eleição. Logo depois veio a ditadura também, então já se nomeou conservador, por isso que a família do Roriz domina, porque ele já foi nomeado governador. Foram pessoas sem um pensamento de vanguarda que construíram Brasília e ela nasceu junto a ditadura. Já nasce sob esse contexto. Então historicamente Brasília nunca foi receptiva a inclusão social dos ditos doentes mentais.

Ao meu ver o manicômio existe a partir do momento que as cidades também existiram. Quando teve aquela mudança da área rural para a urbana, se cria um manicômio para colocar os indesejantes para a cidade funcionar de uma maneira melhor, isso não concepção deles. Então aqui não fugiu disso, criou-se um manicômio, antigamente o São Vicente ${ }^{155}$ era chamado de $\operatorname{HPAP}^{156}$ onde era o único serviço prestado a comunidade de saúde mental. Ali lotava, tinham 400, 500 pessoas internadas, que recebiam tratamento público, quero dizer não é tratamento, sofriam a exclusão naquele espaço. Melhorou um pouco, quando veio um governador chamado Cristovam ${ }^{157}$ na época ele era do PT hoje ele é do PDT.

Então ele fez uma lei distrital moderníssima, antes mesmo da lei federal, a lei 975 onde tentou abrir as portas do manicômio, com projetos culturais, com as criações dos CAPS. Durou 4 anos e logo em seguida voltou o Roriz e continuou com a política de exclusão. Ate vir a lei 102016 de 2001, que também não foi uma conquista do governo. Na época era o Fernando Henrique Cardoso em 2001, assim há uma conjuntura histórico-social que você teve o lançamento do filme o Bicho de Sete Cabeças e foi um filme que atingiu a classe média com

\footnotetext{
${ }^{155}$ Hospital São Vicente de Paulo (HSVP).

${ }^{156}$ Hospital Pronto Atendimento Psiquiátrico.

${ }^{157}$ Cristovam Buarque.
} 
essa causa do manicômio, que ganhou vários prêmios no Festival de Cinema de Brasília, teve nesta mesma época o relatório sobre a saúde no mundo da ONU, onde a prioridade era a saúde mental. O tema era Cuidar sim Excluir não. Onde eles falaram que era inconcebível que no período em que vivíamos ainda houvesse uma política de exclusão das pessoas com transtorno mental. Os membros da ONU foram forçados a fazerem uma política pública sobre saúde mental e ai forçou o governo a aprovar uma lei sobre saúde mental. Não foi uma vontade autônoma, autêntica, aprovar uma lei que tinha 12 anos tramitando no Congresso.

\section{AD: E hoje em dia como é visto?}

LW: A lei não foi uma coisa construída junto com a sociedade, foi aprovada até por uma pressão externa ao governo, não veio de dentro, não foi discutida amplamente no Congresso, que existe toda uma camada social ainda com má vontade em aplicar a lei.

A lei é bonita e tal, mas não foi aprovada do jeito que foi idealizada, ela já é um avanço, mas como outras leis não há um compromisso. Existem as forças externas, a força do setor privado, se a lei for aplicada como deve ser, se os CAPS funcionarem bem, se tiver a criação de espaços de convivência e cultura, residência terapêutica, ambulatório de rua, Programa Vida e Casa e se tiver a aplicação de toda essa rede, as clínicas particulares perdem a força. Você também mexe com a figura e status do médico, porque no hospital psiquiátrico o serviço é centralizado na figura do médico, no CAPS não, um psicólogo, um assistente social podem ser gerentes do local, ou seja, você tem um poder horizontal e não vertical.

Ainda hoje é muito difícil fugir deste contexto privado. Brasília é muito conservadora, aqui mesmo, no Plano Piloto nós não temos um CAPS II. Já tentaram implementar mas a sociedade não deixa e resiste a esta idéia de que na sua vizinhança tem um lugar para loucos, esse estigma, que eles são perigosos, incapazes, que o imóvel da pessoa vai ficar desvalorizado. Isso é uma falta de habilidade do governo, porque o governo ao invés de implementar forçadamente um serviço para cumprir a lei ele deveria contagiar a população, deveria por via de eventos culturais ir sensibilizando esta população sobre a causa da saúde mental, sobre a necessidade de ter um serviço por perto. Muita gente de Brasília não vê isso como necessidade, porque se precisar vai atrás de uma clínica particular.

Outra coisa que vejo, mas é no Brasil todo. A saúde mental, que para mim este termo é redutor 
da questão, porque no meu ponto de vista é uma questão existencial, é uma saúde existencial, então essa área só se trabalha com a própria área da saúde. O que é um grande erro. $\mathrm{O}$ currículo dos terapeutas ocupacionais, assistentes sociais, psicólogos, psiquiatras, são currículos que visam a doença, ainda se tenta cuidar no sentido de curar a pessoa, de diagnosticar, de rotular, tem que ter uma intersetorialidade. Um diálogo com outras profissões. Abrir o CAPS para a comunidade. Estamos distantes desta prática, no Brasil. Aqui especialmente que não temos nenhum espaço de parceria com pontos de cultura ou locais de centro de convivência. Não tem diálogo com a comunidade. O CAPS foi feito para dialogar com a comunidade. O lugar do manicômio é este, o de segregação, ele fica longe da cidade, onde você acumula pessoas e no CAPS você entrega para a comunidade. O serviço tem que ser predominantemente comunitário.

\section{AD: Como o movimento pro saúde mental vê o hospital psiquiátrico?}

LW: O movimento social é muito refém dos hospitais psiquiátricos. Porque foi uma zona de conforto que o governo criou para lidar com a crise. O sistema ainda precisa de um manicômio, no sentindo de que se acabar um manicômio perde-se a referência para onde deixar uma pessoa em crise. Exemplo: se uma pessoa tem um surto dentro de um CAPS, o CAPS ainda não está instrumentalizado para lidar com aquilo, então leva para o HSVP que é um manicômio.

É o papel do movimento querer acabar com o manicômio, é indecente nos dias de hoje esses lugares. Mas se você acaba com ele, até as pessoas que tem visão antimanicomial sentem-se inseguras, porque para onde vai encaminhar? Isso por quê? É uma armadilha que fizeram com o movimento antimanicomial que teve muita força especialmente na década de 80 . Então fizeram assim: Ah, o movimento é antimanicomial, vocês não querem o manicômio? Então vamos acabar com eles. Aí, em algumas regiões acabaram os manicômios, a população que precisava de um tratamento ia para as ruas ficavam abandonadas e a população se voltou contra o movimento.

A idéia não é está, somos a favor de serviços substitutivos. Um desses serviços é o CAPS III que funciona aos finais de semana e por $24 \mathrm{~h}$ e os centros de convivência. Se alguém tiver uma crise pode ir para lá ficar três, quatro dias, para suportar A CRISE. Não justifica a pessoa ficar isolada 4 meses. Não é empírico que uma pessoa tenha que ficar tanto tempo presa no intuito 
de melhorar. É para ter as residências terapêuticas, onde uma pessoa quando não tem uma família, pode ficar com outros pacientes tendo suporte e acolhimento de uma equipe profissional e de cuidadores. E além disso, tínhamos o programa Vida em Casa, Brasília foi pioneira nesse programa. A pessoa vai para casa e uma equipe vai visitá-la, vê como está a medicação, faz um trabalho expressivo junto a família para evitar outra crise. Só que aqui a gente tinha pouco recurso para o Vida em Casa, não tem CAPS III e nem residência terapêutica. Por isso que somos refém do São Vicente.

Queremos o fim do manicômio, mas com este fim é muito incerto para o tratamento e o governo pode vir a colocar contra o movimento. $\mathrm{O}$ movimento é justamente para isso. $\mathrm{O}$ movimento social serve para tencionar, não é para resolver nada. Quem resolve são os gestores nomeados e que ganham muito bem para isso. É a DISAM ${ }^{158}$ Secretaria de Saúde, o governador. O pedido do fim do manicômio não é algo fora da legislação, é um movimento que pelo contrário segue uma legislação. A lei que diz, que ela foi aprovada em 2001 e então em quatro anos os leitos nos hospitais psiquiátricos deveriam ser extinguidos e não o são.

Mas é isso, é o governo público influenciado por grandes empreiteiras, grandes incorporações, não podemos ser inocente, que se o sistema público da reforma psiquiátrica funciona, se os CAPS faze o papel dele e toda a rede de apoio funciona, as pessoas que usufruem desta rede ela também vão precisar de menos medicamento, ou seja, ela vai precisar menos do poder do médico. Porque ela vai ter outras vias para expressar sua dor. Então você tem por trás o poder médico, o da indústria farmacêutica que mantêm estes manicômios. Se gasta muito medicamento dentro destes manicômios, seja público ou privado.

Tive uma experiência em uma clínica particular, logo quando me formei. Tinham 80 pacientes e os 80 pacientes tomavam Rivotril. Então isso acontece em todas as clínicasporque chega um momento a noite, que como fica somente a equipe de plantão e os enfermeiros, os médicos indicam um ansiolítico, seja o Clonazepam (rivotril), ou o Diazepam, para todo mundo ficar quieto, ficar manso. Então, você imagina o tanto de medicamento que se vende por conta disso. Porque não é mais uma prescrição clínica e sim social, para que na clínica fique de boa. Ou seja, é uma banalização da medicalização.

\section{AD: Você acha que a formação dos profissionais de saúde nas universidades ainda está}

\footnotetext{
${ }^{158}$ Diretoria de Saúde Mental.
} 


\section{seguindo um modelo clássico? Ou acontece alguma sensibilização?}

TP: Eu vejo que ainda tem o estudo muito clássico. Não se tem uma disciplina de psiquiatria comunitária, de como trabalhar uma rede comunitária. Você não vê nenhuma área da psiquiatria utilizando homeopatia ou fitoterápicos, não tem esse lado alternativo da psiquiatria. Um não substitui o outro, isso seria complementar. Há pouco tempo mesmo fui a Itália, em Trieste, onde existe uma reforma psiquiátrica em vigor e ate é referência da ONU para tratamento em saúde mental. Fomos em um centro de convivência para dependentes químicos que eles trabalham com a questão fitoterápica. Um conjunto de chás, ervas, para ajudar a pessoa seja na ansiedade, no estresse, isso combinado com medicações mesmo alopáticos.

Ainda é muito tradicional. Não se tem uma visão, sócio cultural da loucura. A loucura é completamente cultural. Só existe louco porque uma cultura chama de loucura. Na Índia pode ser um xamã, na França o louco. A questão é muito bioquímica ainda. Estuda o corpo e a química do corpo. E até mesmo na psicologia agora que se está tendo muito estudo sobre a psicologia social. Na universidade que dou aula este é o primeiro semestre que tem a Psicologia Comunitária. O reflexo da saúde mental é o reflexo do currículo acadêmico. Por isso que tem que ter a intersetorialiedade para que venham artistas em geral e gente das ciências políticas e sociais para interagir com gente da saúde. Para poder abrir a mente.

\section{AD: Como você vê pela Ong Inverso a arte e seu auxílio no tratamento psiquiátrico?}

TP: A arte ela dá outras maneiras da pessoa se expressar. Porque a dor emocional ela é muitas vezes indizível ela tem que ser expressa de outras maneiras. Então a pessoa pode expressar esta dor, pela pintura, corpo, até mesmo pela conversa receptiva, onde ela possa expressar tudo que sente. Uma das coisas que vemos pela Inverso é que a arte ela dá uma nova identidade para a pessoa primeiro. Se essa arte é feita na rua ela tenta fazer uma recriação do espaço social, integrando a pessoa e a comunidade, os ditos doentes mentais sentem-se mais pertencentes, se apropriam da cidade. Ela deixa de ser um espaço de exclusão e passa a ser um espaço de interação, isso muda o estigma da loucura e a vizinhança passa a ser mais acolhedora.

A Inverso sofreu muito com isso. Quando foi implementada os vizinhos ficaram com muito 
receio: "Vai ser um espaço para loucos". "Meu comércio, meu imóvel vai desvalorizar". "Nossa eles podem vir aqui quebrar alguma coisa". Só que os freqüentadores da Inverso tem a chave do local, nós temos está confiança, porque sabemos que se o local for acolhedor não tem porque ter crise. A crise vem muitas vezes quando eles não conseguem se expressar. Então a Inverso fez muito trabalho nas ruas e as pessoas puderam aceitar que eles são criativos, tem potencial.

A arte deu uma identidade. Porque na sociedade que a gente vive nós somos nosso trabalho. Ela é o que ela faz. Então o que você é? Eu sou psicólogo, advogado... Não falamos: “Ah, eu sou legal e tal". Mas no caso dos transtornos mentais não acontece isso a pessoa se identifica com a doença. Então o que você é? "Eu sou esquizofrênico", "um bipolar", "um depressivo". Conseguimos com que muitos freqüentadores tirassem a carteira de artesão então eles falam: "Eu sou artesão". Na minha oficina de instrumento, quem dá aula mesmo é um mestre de bateria da Acadêmicos da Asa Norte e quando perguntam o que eles são eles dizem: "Eu sou um ritmista”. A gente fortalece a personalidade e gera a identidade. Não queremos negar as limitações que esta pessoa tem, mas queremos valorizar a potencialidade. A gente quer transformar o sintoma em um potencial criativo. Se ela quer bater que bata... Em um tamborim.

\section{AD: O que é corpo?}

TP: Corpo para mim é uma morada, é a morada do ser humano, a gente pode mudar de cidade, de casa, de cor de cabelo, fazer plásticas e etc. Mas o corpo é o lugar onde a moramos. A gente não foge do corpo. O trabalho de conscientização corporal é muito importante, porque hoje em dia parece que o corpo é algo além. Acho que há um estranhamento da pessoa com o próprio corpo, mas tudo esta no corpo. O psicólogo trabalha com a audição da pessoa, com a fala da pessoa. O psiquiatra trabalha com o organismo é com fígado, com os rins, os medicamentos atacam estas regiões. O corpo é

tudo. É muito difícil separar o que e corpo o que é mente, espírito. O corpo é a morada de tudo, tudo é sentido pelo corpo.

\section{AD: O que é saúde mental?}

TP: É algo além do mental. Eu também sempre questionei este termo porque se você usa 
parece que é só uma questão de saúde e para mim é uma questão existencial a existência que esta em crise, a existência que esta doendo, não é só mental. É difícil de separar, as vezes uma insônia pode causar um surto, acho que temos que levar a saúde mental para um campo maior da existência da pessoa, a existência é isso, tudo que pertence a vida.

Um conflito espiritual pode levar a loucura, a perda de um ente querido ou até mesmo coisas muito grandes como ganhar na mega sena, ou seja, dores e alegrias, tudo que transborda a existência da pessoa pode causar certo sofrimento. Este termo saúde mental é reducionista, como é usado nós temos que tomar em uma amplitude onde inclua outros agendes que não só da saúde. Saúde mental quer dizer tudo que envolve o bem estar, cidadania. 


\section{ANEXO 5: DVD}

DVD com apresentações e trabalhos realizados durante pesquisa de mestrado acadêmico. 